Tese de doutorado

Orientador: Professor Associado Otavio Pinto e Silva

UNIVERSIDADE DE SÃO PAULO

FACULDADE DE DIREITO

São Paulo - SP 


\title{
CONSUMO E TRABALHO: IMPACTOS NO MEIO AMBIENTE DO TRABALHO E NA SAÚDE DO TRABALHADOR
}

\begin{abstract}
Tese de doutorado apresentada ao Programa de Pós-Graduação em Direito da Universidade de São Paulo, como requisito para obtenção do título de doutor em Direito do Trabalho, sob a orientação do Professor Associado Otavio Pinto e Silva.
\end{abstract}

UNIVERSIDADE DE SÃO PAULO

FACULDADE DE DIREITO

São Paulo - SP 
BANCA EXAMINADORA:

Prof. Associado Otavio Pinto e Silva (Orientador)

São Paulo, de de 
Aos meus pais, Silvio de Almeida Filho e Maria Inês Macedo Matos de Almeida, meus eternos credores e amados incentivadores.

À Lilian Carla de Almeida, minha irmã e melhor companhia, razão pela qual desconheço o peso da solidão.

Ao amigo e sócio Fabiano Carvalho, a quem sou infinitamente grato pelos ensinamentos de vida e de direito.

À amiga e eterna orientadora Mara Ignez Campos de Carvalho, a primeira pessoa a acreditar e a incentivar essa conquista.

À amiga Graziella Ambrosio, a primeira a me apresentar o vasto e fascinante universo do Direito do Trabalho.

À amiga Tatiana Noronha de Souza, que me conduziu - e ainda conduz - pelos caminhos de pedra da pesquisa científica.

E aos meus alunos do Centro Universitário Moura Lacerda, da Fundação Armando Álvares Penteado (FAAP) e da Escola Superior de Advocacia da Ordem dos Advogados do Brasil - Subsecção Ribeirão Preto, que mantêm em mim acesa a paixão sagrada pela docência. 


\section{AGRADECIMENTOS}

Aos amigos pós-graduandos Aline Moreira da Costa, Leandro Krebs Gonçalves, Cibele Linero Goldfarb, Luiz Henrique Sormani Barbugiani, Gisele Accarino Martins Genofre, Maria Beatriz Ribeiro Dias, Tatiana Guimarães Ferraz Andrade, Renato Almeida Muçouçah e Mário Carboni, pelo encontro e pelos inesquecíveis momentos compartilhados em todos esses anos.

Aos Professores Homero Batista Mateus da Silva, Vera Navarro e Katia de Souza Amorim, pelos preciosos e impagáveis ensinamentos.

Aos Professores Sandra Ortolan, Yone Frediani, Marcos da Silva Pôrto, Jorge Cavalcanti Boucinhas Filho e Flávia Meziara, pelo estímulo, oportunidades e confiança profissional.

Aos amigos Flávia Costa Alcova, Aretha e Amanda Pierini Uzun, Ana Maria Lapria Faria, Danilo Tavares, Mirian Cristina Cano, Simone e Amanda Frugis, Camila Angeli Ribeiro, Alexandre Colucci, Maria Carolina do Prado Haram Colucci, João Carlos da Silva Bizário, Jaime Bulos, Maria Helena Alves de Faria, Noemi Costa Pereira, Carolina Assed Ferreira, André Evangelista de Souza, Iully Freire e da MKG Consultoria, pela alegria de têlos em minha vida.

À Professora Maria Hemília Fonseca, que jamais poderia ter deixado de cruzar o meu caminho nessa existência, pelas preciosas lições e contribuições.

Aos Professores Sueli Dallari e Homero Batista Mateus da Silva, pelas caudalosas e imprescindíveis ponderações feitas na ocasião do exame de qualificação.

Ao Professor Otávio Pinto e Silva, meu orientador e eterna referência profissional, pelo incentivo, confiança e, sobretudo, pelo privilégio da amizade; seria preciso mais do que uma vida inteira para retribuí-lo pelas transformações por ele operadas em minha vida.

Aos participantes desta pesquisa, por terem dedicado parte do seu tempo às entrevistas.

E a Deus, pois sem ele nada passaria de um simples projeto. 
A aproximação do que quer que seja, se faz gradualmente e penosamente - atravessando inclusive o oposto daquilo de que se vai aproximar.

Clarice Lispector 


\section{RESUMO}

A Constituição da República Federativa do Brasil de 1988, seguindo os passos da Organização Internacional do Trabalho, elevou a saúde do trabalhador e o meio ambiente do trabalho equilibrado ao patamar de direitos humanos, reconhecendo-o como uma manifestação particular ambiental indispensável ao desenvolvimento e à condição humana. A noção de meio ambiente do trabalho não pode ser imutável e deve refletir a sua natureza multidimensional e interdependente, considerando tanto as constantes evoluções técnicas e sua indissociabilidade dos sistemas econômico, social, político, cultural e jurídico nos quais é envolto, como a inter-relação trabalhador-ambiente. O trabalhador também integra o meio ambiente do trabalho, pois não existe trabalhador sem meio ambiente do trabalho, tampouco meio ambiente do trabalho sem trabalhador. Compreender essa complexa e dinâmica interação é o primeiro passo para se buscar o equilíbrio de um meio que não é apenas influenciado por fatores ambientais (geográficos, arquitetural-tecnológicos, organizacionais e culturais), mas também por fatores pessoais (biogenéticos, psicológicos e comportamentais) e contextos correlatos que estabelecem padrões para as estruturas e atividades ocorridas no plano laboral, de modo a repercutir na saúde do trabalhador. Considerando a inter-relação pessoa-ambiente e a interdependência entre contextos ambientais, o presente estudo teve como objetivo sistematizar os fatores e aspectos que compõem o meio ambiente do trabalho e demonstrar a influência da estrutura socioeconômica consumerista no seu equilíbrio e na saúde do trabalhador. Por ser tratar de um campo de estudo indiscutivelmente multidisciplinar, sendo diversas as ciências que o tomam como objeto, o referencial teórico proposto compreende uma intersecção entre Direito do Trabalho e Psicologia Ambiental. Quanto ao método, trata-se de uma abordagem multimetodológica qualitativa pautada na pesquisa bibliográfica, na análise de conteúdo e no método de caso, por meio do qual buscouse analisar o fenômeno investigado tendo como pano de fundo a atividade de telemarketing. Concluiu-se pela necessidade de harmonização das políticas e normas trabalhistas e consumeristas, seja por meio da sistematização do ordenamento jurídico, da função integradora dos princípios jurídicos ou da efetiva atuação integrada dos diversos atores sociais, devendo-se lembrar que o equilíbrio do meio ambiente do trabalho, um dos pilares do direito à saúde, ao trabalho e à dignidade humana, é interdependente das manifestações macrossistêmicas dos sistemas social, econômico, político, cultural e jurídico, os quais estabelecem padrões para as estruturas e atividades que ocorrem no contexto laboral (CNPq).

Palavras-chave: direito do trabalho, meio ambiente do trabalho, consumo, saúde do trabalhador, psicologia ambiental. 


\begin{abstract}
The Constitution of the Federative Republic of Brazil in 1988, following the footsteps of the International Labour Organization, raised worker health and the work environment levelheaded to the level of human rights, recognizing it as a particular environmental manifestation indispensable for the development and the human condition. The sense of working environment cannot be immutable and must reflect the multidimensional and interdependent nature, considering both the constant technical developments and their inseparability of economic, social, political, cultural and legal systems, in which is wrapped, as the interrelationship worker-environment. The worker also integrates the working environment, because there is no worker without work environment, neither work environment without worker. Understanding this complex and dynamic interaction is the first step to search balance in an environment that is not only influenced by environmental factors (geographical, architectural-technological, organizational and cultural), but also by personal factors (biogenetic, psychological and behavioral) and related contexts, which establish standards for structures and activities that have occurred in labor plan, to impact on workers' health. Considering the inter relationship person-environment and interdependence between environmental contexts, this study aimed to systematize the factors and aspects that make up the working environment and to demonstrate the influence of consumerist socioeconomic structure in its balance and worker health. Because it is an undoubtly multidisciplinary field of study, and several sciences that take as object, the theoretical framework proposed comprises an intersection between Labour Law and Environmental Psychology. About the method, it is a qualitative multi methodological approach guided by the literature search, the content analysis and case method, whereby we attempted to analyze the phenomenon under investigation having as background the telemarketing activity. It was concluded by the need for harmonization of politics and consumerists and labor standards, or by the systematization of the legal system, the integrative function of legal principles or the effective integrated performance of various social actors, we should remember that the balance of the work environment, one of the pillars of the right to health, work and human dignity, is interdependent of macro systemic manifestations of social, economic, political, cultural and legal systems, which establish standards for structures and activities that occur in the labour context (CNPq).
\end{abstract}

Keywords: Labour law, work environment, consumption, occupational health, environmental psychology. 


\section{RÉSUMÉ}

La Constitution de la République Fédérative du Brésil en 1988, en suivant des traces de l'Organisation Internationale du Travail, ont elevé la santé des travailleurs et de l'environnement du travail équilibré au niveau des droits de l'homme et les reconnaît comme une manifestation particulière indispensable pour le progrès humain et de l'environnement. La notion d'environnement du travail ne peut pas être immuable et doit réfléchir sa nature multidimensionnelle et son interdépendance, en considérant la constante évolution technique et sa inséparabilité des systèmes économiques, du progrès social, politique, culturel et juridique où il est enveloppé, comme une corrélation entre travailleur et environnement. Le travailleur intègre également l'environnement du travail, puisqu'il n'y a pas de travailleur sans l'environnement de travail, ni d'environnement de travail sans le travailleur. La compréhension de cette interaction complexe et dynamique est la première étape pour rechercher l'équilibre d'un ambiance qui n'est pas seulement affecté par les facteurs environnementaux (géographiques, architecturales, technologique, organisationnel et culturel), mais aussi par les facteurs personnels (biogénétique, psychologiques et comportementales) et par des contextes connexes qui établissent des normes pour les structures et les activités liées au travail et à la santé des travailleurs. Compte tenu de la relation entre personne-environnement et l'interdépendance entre les contextes environnementaux, cette étude a visé systématiser les facteurs et les aspects qui composent l'environnement du travail et prouver l'influence de la structure socio-économique consumériste dans son équilibre et de la santé du travailleur. Puisque c'est un domaine indiscutablement multidisciplinaire d'étude, où il y a des diverses sciences qui l'ont pour objet, le cadre théorique proposé comprend une intersection entre le travail et la psychologie de l'environnement. Quant à la méthode, elle s'agit d'une abordage multimethodological qualitative fondée sur la recherche bibliographique, l'analyse du contenu et la méthode des cas, en examinant le phénomène recherché dans le contexte de l'activité de télémarketing. Finalement, il faut conclure qu'il y a la nécessité d'harmonizer les politiques et les normes du travail et de la consommation à travers de la systématisation de l'ordonnance juridique, de l'intégration des principes juridiques ou de l'effective activité intégréé des divers acteurs sociaux. Il ne faut pas oublier que l'équilibre de l'environnement du travail, un des piliers du droit à la santé, au travail et à la dignité humaine, est lié aux manifestations des systèmes social, économique, politique, culturel et juridique lesquels établissent des normes pour les structures et les activités qui existent dans le contexte du travail (CNPq).

Mots-clés: droit du travail, environnement de travail, consumición, la santé du travailleur, la psychologie environnementale. 


\section{LISTA DE ABREVIATURAS E SIGLAS}

$\S$ - Parágrafo

ANAC - Agência Nacional de Aviação Civil

ANATEL - Agência Nacional de Telecomunicações

Art. - Artigo

Arts. - Artigos

CAT - Comunicação de Acidente do Trabalho

$\mathrm{CF}$ - Constituição Federal

CLT - Consolidação das Leis do Trabalho

CRFB - Constituição da República Federativa do Brasil

CS - Consumidor

DEJT - Diário Eletrônico da Justiça do Trabalho

DIEESE - Departamento Intersindical de Estatística e Estudos Socioeconômicos

DOE - Diário Oficial do Estado

DORT - Distúrbios Osteomusculares Relacionados ao Trabalho

ED - Embargos de Declaração

LER - Lesões por esforços repetitivos

MT - Magistrado do Trabalho

MTE - Ministério do Trabalho e Emprego

NR - Norma Regulamentadora

OIT - Organização Internacional do Trabalho

OJ - Orientação Jurisprudencial

P.A. - Posto de Atendimento

PCMSO - Programa de Controle Médico de Saúde Ocupacional

PNUD - Programa das Nações Unidas para o Desenvolvimento

PPRA - Programa de Prevenção de Riscos Ambientais

RH - Recursos Humanos

RO - Recurso Ordinário

RR - Recurso de Revista

SAC - Serviço de Atendimento ao Consumidor

SDI - Seção Especializada de Dissídios Individuais

STF - Supremo Tribunal Federal

SUS - Sistema Único de Saúde

TRT - Tribunal Regional do Trabalho

TST - Tribunal Superior do Trabalho 


\section{LISTA DE FIGURAS}

Figura 1. A interdependência contextual na inter-relação pessoa-ambiente

Figura 2. Sistematização dos fatores e aspectos componentes do meio ambiente do trabalho

Figura 3. Sistemas que integram o macrossistema e a interdependência com o meio ambiente do trabalho

Figura 4. Opinião dos consumidores participantes sobre a qualidade e eficácia dos serviço de telemarketing

Figura 5. Serviços de Atendimento ao Consumidor mais criticados, organizados por setores

Figura 6. Justificativas da insatisfação com os serviços de telemarketing

Figura 7. Quantidade de acidentes do trabalho no setor de teleatendimento, com e sem emissão de Comunicação de Acidente de Trabalho (CAT), segundo a Classificação Nacional de Atividades Econômicas (CNAE) - 2006/2011 ....

Figura 8. Quantidade de acidentes do trabalho no setor de teleatendimento, por situação do registro e motivo, segundo a Classificação Nacional de Atividades Econômicas (CNAE) - 2006/2011 


\section{SUMÁRIO}

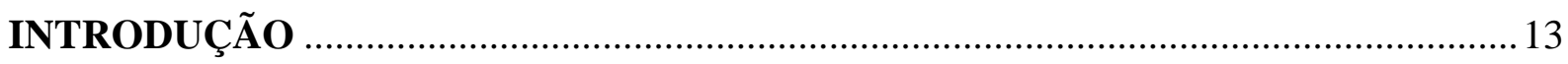

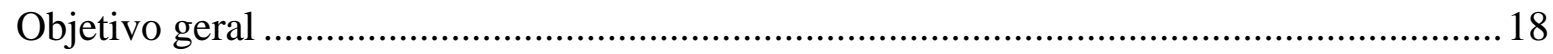

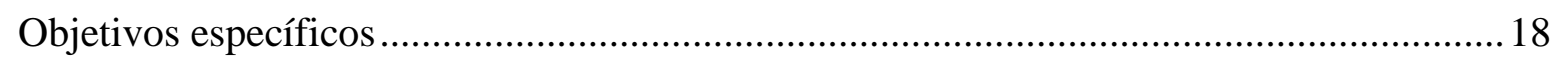

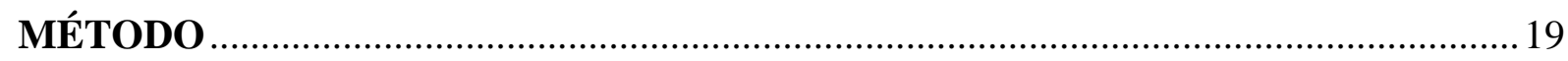

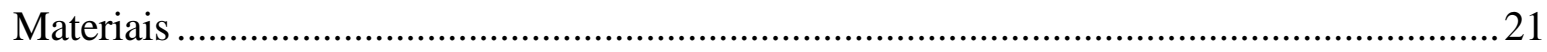

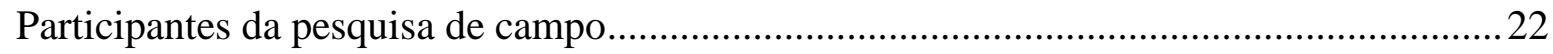

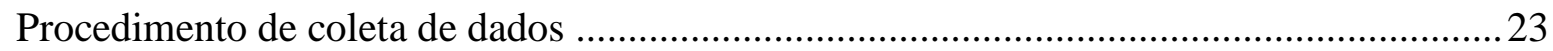

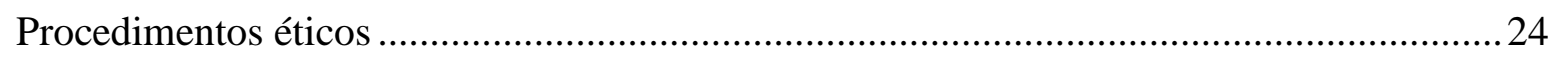

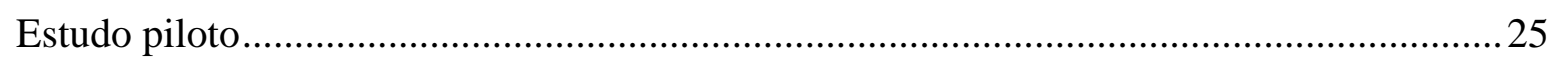

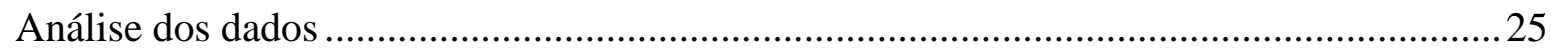

1 A RESSIGNIFICAÇÃO DO TRABALHO E DO MEIO AMBIENTE DO TRABALHO: UMA PERSPECTIVA HISTÓRICO-EVOLUTIVA …..........................28

1.1 A Revolução Industrial como um divisor de águas na história do trabalho ...................28

1.2 Taylorismo, Fordismo e Toyotismo: a reorganização do processo produtivo e seus

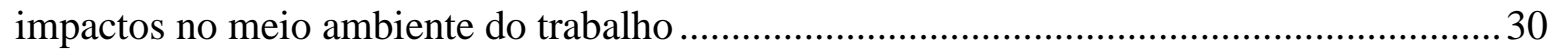

1.3 A contemporânea Revolução das Tecnologias da Informação e Comunicação e seus

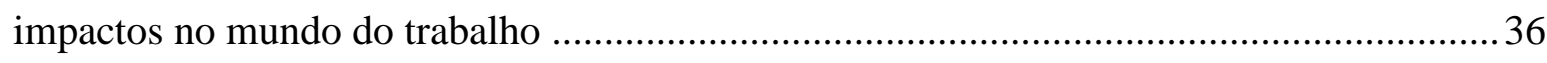

2 OS IMPACTOS ECONÔMICOS DO CONSUMO NO MUNDO DO TRABALHO ... 39

$2.1 \mathrm{O}$ surgimento da sociedade do consumo e seus impactos no mundo do trabalho ...........39

2.2 Consumidor, fornecedor e relação de consumo........................................................ 44

2.3 Vulnerabilidade e hipossuficiência: conceito e principiologia .................................... 48

2.4 A harmonização da relação de consumo: finalidade e mecanismos de viabilização.......55

2.5 A harmonização da relação de consumo e seus impactos no mundo do trabalho ..........58

3 MEIO AMBIENTE DO TRABALHO E SAÚDE DO TRABALHADOR ..................... 62

3.1 A construção do conceito jurídico de meio ambiente do trabalho ...............................62

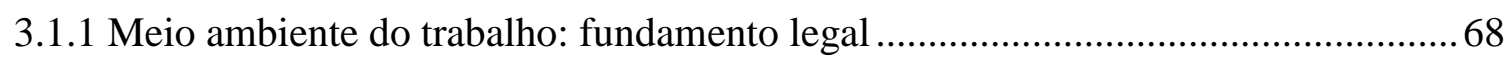

3.1.2 Meio ambiente do trabalho: princípios jurídicos .................................................... 70

3.2 O meio ambiente do trabalho sob a perspectiva da Psicologia Ambiental.................... 79 
3.2.1 Pressupostos da abordagem ecológica: um paradoxo com a noção sistêmica ambiental

3.3 O Princípio da Bidirecionalidade e o Princípio da Interdependência como propostas deste estudo

3.4 Uma concepção moderna de saúde do trabalhador como condição de um meio ambiente do trabalho equilibrado 102

3.5 Fatores e aspectos que compõem o meio ambiente do trabalho: uma sistematização necessária.

3.6 A saúde do trabalhador como um direito fundamental.

4 UMA RADIOGRAFIA DO TELEMARKETING

4.1 Entendendo o telemarketing 123

4.2 Radiografia do telemarketing: Brasil e outros países

4.3 A precarização do trabalho em telemarketing ....

4.3.1 Terceirização: um contexto propício para a precarização da atividade

4.4 As novas regras para o Serviço de Atendimento ao Consumidor versus Anexo II da

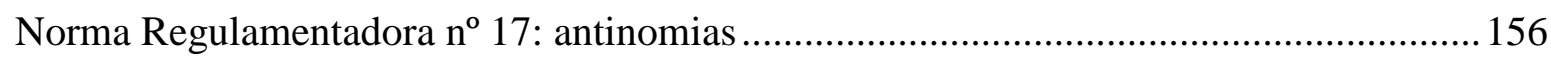

4.4.1 A relação pessoa-ambiente e o Anexo II da Norma Regulamentadora $n^{\circ} 17 \ldots \ldots . .166$ 4.4.2 O trabalho em telemarketing após a vigência do Anexo II da Norma Regulamentadora $\mathrm{n}^{\circ} 17$

4.5 Telemarketing e outra(s) atividade(s): semelhanças

5 CONSUMO E TRABALHO: IMPACTOS NO MEIO AMBIENTE DO TRABALHO E NA SAÚDE DO TRABALHADOR

5.1 A interdependência entre consumo e trabalho e seus impactos no contexto laboral....197

5.2 A atuação dos atores sociais na efetivação do direito à saúde e ao meio ambiente do trabalho equilibrado: uma integração necessária...........................................................203

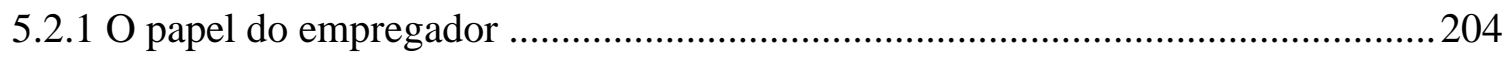

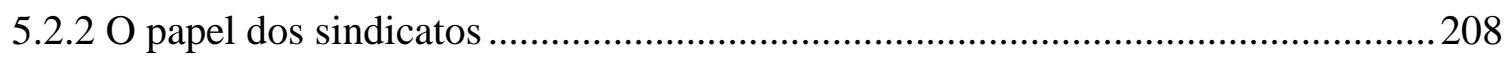

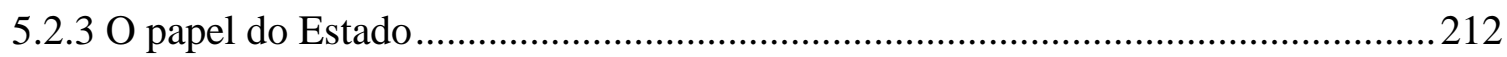

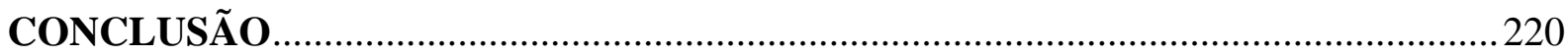

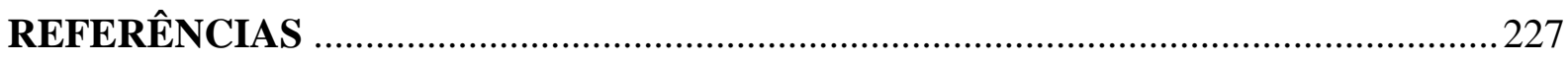

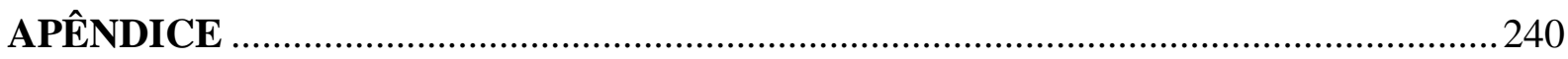

Termo de Consentimento Livre e Esclarecido ...........................................................241 


\section{INTRODUÇÃO}

A Revolução Industrial, seguida das sucessivas propostas de reorganização do trabalho, é um marco histórico de transformações socioeconômicas e um importante divisor de águas para o campo da saúde do trabalhador. A realização do trabalho nos centros urbanos industriais, inaugurados pela Revolução Industrial, sob rígida fiscalização, intenso ritmo de trabalho e precárias condições ambientais e funcionais, justificou a necessidade de proteção do trabalhador e da criação do Direito do Trabalho.

Uma das principais mudanças impostas pela industrialização implicou na separação entre local de trabalho e moradia, em razão do processo de mecanização que impossibilitou a realização do trabalho fora do ambiente fabril, onde se encontravam os maquinários. Contudo, se por um lado a industrialização impulsionou a criação de um mercado consumerista, o aumento da produtividade, a redução dos preços e a acessibilidade aos bens de consumo, por outro, favoreceu a aceleração do ritmo da produção e a exploração dos trabalhadores, expropriados de seus bens mais fundamentais, como a saúde e a dignidade.

Nas últimas décadas do século XX, a internacionalização da economia e a sofisticação tecnológica decorrente da contemporânea Revolução das Tecnologias da Informação e Comunicação não apenas trouxeram novas perspectivas para a atividade econômica, sobretudo pela supressão de fronteiras e pela reinvenção do processo produtivo, mas também desencadearam um complexo processo de modificações técnicas e organizacionais que jamais poderiam ser desprezadas pelo Direito do Trabalho.

A diversidade de estudos nas mais variadas áreas do conhecimento (Direito, Medicina, Psicologia, Economia, Saúde Pública, Sociologia, etc.) tem demonstrado os impactos dos processos de modernização técnica e organizacional na saúde do trabalhador. Se por um lado a sofisticação tecnológica possibilitou aprimorar o conteúdo organizacional do trabalho, permitindo a simplificação do processo produtivo e a redução do tempo de execução 
das tarefas, em revés, tornou o labor mais intenso, compacto e amplamente controlado ${ }^{1}$, fomentando a velha quizila entre capital e trabalho.

Essa tensão entre interesses econômicos e sociais evidentemente repercutiu, e ainda repercute, no universo do trabalho, impactando tanto na organização como nas condições laborais, que influenciam na saúde do trabalhador dentro e fora do meio ambiente do trabalho, pois "o mundo é um só e os trabalhadores existem, neste mundo, transformado e sendo transformados por ele",2.

Sendo o campo da saúde do trabalhador uma seara eminentemente interdisciplinar, para que melhor se compreenda a complexidade do meio ambiente do trabalho, sua interdependência com outros contextos e sistemas ambientais e a inter-relação trabalhador-ambiente, este estudo se apoia numa abordagem interdisciplinar entre Direito do Trabalho e Psicologia Ambiental.

Desde a década de 70, a Psicologia Ambiental, um dos campos de pesquisa e intervenção na Psicologia, dedica-se ao estudo da inter-relação pessoa-ambiente, priorizando a influência dos aspectos físicos ambientais no comportamento humano. A perspectiva da abordagem ecológica de Urie Bronfenbrenner ${ }^{3}$ e a concepção do ambiente sócio-físico de Daniel Stokols ${ }^{4}$ constituem dois caudalosos referenciais teóricos que muito se aproximam da perspectiva sistêmica e da gestalt $^{5}$ esposada na doutrina jurídica labor-ambiental.

Com base nesses referenciais da Psicologia Ambiental, do Direito Laborambiental, este estudo considera que todos os aspetos constituintes do meio ambiente do trabalho, sejam eles físicos (ambientais - geográficos, arquiteturais-tecnológicos, organizacionais e socioculturais) ou não físicos (pessoais - comportamentais e psicológicos), são inter-relacionados e produzem tanto mudanças quanto continuidade nas características da pessoa, influenciando, inclusive, no seu estado de saúde. O trabalhador influi no meio ambiente do trabalho e este na maneira como ele percebe, experimenta, vivencia e interage

\footnotetext{
${ }^{1}$ MOURA, Mauro Azevedo de. Novas tecnologias. Revista Brasileira de Saúde Ocupacional, São Paulo, v. 21, n. 79, p. 63-75, jul./set. 1993.

${ }^{2}$ DIAS, Elizabeth Costa. Aspectos atuais da saúde do trabalhador no Brasil. In: ROCHA, Lys Esther; BUSCHINELLI, Tarcísio José; RIGOTTO, Raquel Maria. (Orgs.). Isto é trabalho de gente? Vida, doença e trabalho no Brasil. Petrópolis: Vozes, 1993. p. 139.

${ }^{3}$ BRONFENBRENNER, Urie. Toward an experimental ecology of human development. American Psychologist, Washington, v. 32, p. 513-531, 1977.

${ }^{4}$ STOKOLS, Daniel. Establishing and maintaining healthy environments. American Psychologist, Washington, v. 47, n. 1, p. 6-22, 1992.

${ }^{5}$ FELICIANO, Guilherme Guimarães. Meio ambiente do trabalho: aspectos gerais e propedêuticos. Síntese Trabalhista, Porto Alegre, v. 14, n. 162, p. 122-153, dez. 2002.
} 
com o trabalho e seu contexto. Isso porque o trabalhador não apenas está no meio ambiente do trabalho, mas também dele faz parte, pois não existe trabalhador sem meio ambiente do trabalho, tampouco meio ambiente do trabalho sem trabalhador.

A interdependência entre meio ambiente do trabalho e outros contextos (mediatos e imediatos) e sistemas ambientais (econômico, social, político, cultural e jurídico) também é outro fenômeno considerado neste estudo, que aborda a interdependência entre os contextos laboral e consumerista e seus impactos no meio ambiente do trabalho e na saúde do trabalhador. Esses dois contextos, além de interdependentes, são influenciados pelos elementos macrossistêmicos, quais sejam, sistemas econômico, social, jurídico, político e cultural; protótipos gerais que estabelecem padrões para estruturas e atividades que ocorrem no plano concreto ${ }^{6}$.

A sobreposição dos direitos do consumidor aos direitos do trabalhador tem sido observada em diversas situações, em detrimento da natureza fundamental dos direitos ao trabalho, à vida, à saúde e à dignidade do trabalhador. Como pano de fundo, este tudo examina a tensão entre dois dispositivos legais voltados ao telemarketing: o Anexo II da Norma Regulamentadora $n^{\circ} 17$, instituído pela Portaria $n^{\circ}$ 9/2007 do Ministério do Trabalho e Emprego, que estabeleceu parâmetros mínimos ao trabalho em teleatendimento/telemarketing para proporcionar um máximo de conforto, segurança, saúde e desempenho eficiente; e o Decreto $n^{\circ}$ 6.523/2008, regulamentado pela Portaria $n^{\circ}$ 2.014/2008, do Ministério da Justiça, que instituiu medidas para harmonizar a relação de consumo em Serviço de Atendimento ao Consumidor.

Colidentes entre si, esses dois dispositivos exerceram incontestável influência no meio ambiente do trabalho, alcançando a organização, as condições e as relações de trabalho em telemarketing. Por exemplo, enquanto o Decreto $n^{\circ}$ 6.523/08 impôs tempo máximo para a duração da transferência de ligações e de solução para as reclamações, acelerando o ritmo de trabalho sem prejuízo do dever de objetividade e clareza das informações prestadas pelos teleoperadores, o Anexo II da Norma Regulamentadora $n^{\circ} 17$ estabeleceu o aumento de pausas fora do posto de trabalho e a proibição da aceleração do trabalho e da adoção de mecanismos de monitoramento da produtividade (mensagens nos monitores de vídeo, sinais

\footnotetext{
${ }^{6}$ BRONFENBRENNER, Urie. Toward an experimental ecology of human development. American Psychologist, Washington, v. 32, p. 513-531, 1977.
} 
luminosos, sonoros ou indicações do tempo utilizado nas ligações ou de fila de espera de clientes).

Por se tratar de uma seara propícia para a abordagem dos objetivos propostos neste estudo, essa tensão de direitos do consumidor e do trabalhador é analisada no plano contextual do telemarketing que, no Brasil, após a privatização das empresas públicas e do desmonte do setor produtivo estatal no final da década de 1990, passou a ser a principal atividade terceirizada e a segunda maior empregadora, atrás apenas do comércio varejista ${ }^{7}$.

Afora essas motivações de cunho econômico, trata-se de uma atividade recentemente considerada penosa pelo Tribunal Superior do Trabalho, em razão da organização e das condições de trabalho e dos elevados índices de afastamento por doenças ocupacionais e acidentes do trabalho.

Para a abordagem do tema em exame, este estudo apresenta cinco capítulos.

O Capítulo 1 aborda os impactos dos sucessivos processos de reestruturação produtiva no meio ambiente do trabalho e na saúde do trabalhador, desde a Revolução Industrial até a contemporânea Revolução da Tecnologia da Informação e da Comunicação, considerando as influências macrossistêmicas, sobretudo do sistema econômico.

O Capítulo 2 aborda os impactos econômicos do consumo no mundo do trabalho, evidenciando a estreita relação entre os interesses consumeristas e trabalhistas e a interdependência entre esses dois contextos ambientais.

O Capítulo 3 trata da relação entre meio ambiente do trabalho e saúde do trabalhador, como direitos fundamentais. Propõe uma sistematização dos fatores e aspectos constituintes do meio ambiente do trabalho, na perspectiva sócio-física; demonstra a interdependência entre contextos e sistemas ambientais mediatos e imediatos; e propõe dois novos princípios para o rol principiológico labor-ambiental: o Princípio da Bidirecionalidade e o Princípio da Interdependência.

O Capítulo 4 apresenta uma radiografia do telemarketing nas perspectivas funcional, social, econômica e jurídica. Aborda a precarização do trabalho nesse setor, a (i)licitude da terceirização dessa atividade, os conflitos entre o Anexo II da Norma

\footnotetext{
${ }^{7}$ NOGUEIRA, Claudia Mazzei. O trabalho duplicado: a divisão sexual no trabalho e na reprodução: um estudo das trabalhadoras do telemarketing. São Paulo: Expressão Popular, 2006.
} 
Regulamentadora $\mathrm{n}^{\mathrm{o}} 17$ e as novas regras para o Serviço de Atendimento ao Consumidor e verifica semelhanças entre o telemarketing e outra(s) atividade(s).

Por fim, o Capítulo 5 aborda a interdependência entre consumo e trabalho e seus impactos no meio ambiente do trabalho e na saúde do trabalhador. Evidencia a importância da atuação efetiva de diversos atores sociais para a harmonização dos direitos dos consumidores e dos trabalhadores - evitando sobreposição de direitos - e da efetivação do direito à saúde e ao meio ambiente do trabalho equilibrado, para garantir a todos um trabalho digno condizente com a política de promoção dos direitos humanos fundamentais.

Esperamos que este estudo possa contribuir para o alcance de melhores condições de trabalho em telemarketing - e em outras atividades assemelhadas - e para o desenvolvimento de políticas públicas direcionadas ao setor de teleatendimento. Do ponto de vista da relevância, esperamos que os resultados possam gerar conhecimentos a partir da investigação concreta realizada, que possibilitem avanços tanto conceituais como concretos, contribuindo com futuras investigações e beneficiando outras áreas dedicadas à saúde do trabalhador. 


\section{DELIMITAÇÃO DO TEMA: OBJETIVOS}

\section{Objetivo geral}

Sistematizar os fatores e aspectos que compõem o meio ambiente do trabalho e demonstrar a influência da estrutura socioeconômica consumerista no seu equilíbrio e na saúde do trabalhador.

\section{Objetivos específicos}

a) Sistematizar os fatores/aspectos ambientais e pessoais que influenciam na inter-relação trabalhador-meio ambiente do trabalho, sob a perspectiva da saúde do trabalhador;

b) Analisar a interdependência entre meio ambiente do trabalho e outros contextos ambientais, bem como a influência da estrutura socioeconômica consumerista no seu equilíbrio e na saúde do trabalhador;

c) Levantar e discutir ponto(s) de conflito entre o Decreto $n^{\circ} 6.523 / 2008$ e a Portaria $n^{\circ}$ 2.014/2008, do Ministério da Justiça, e a Portaria no 9/2007, do Ministério do Trabalho e Emprego;

d) Analisar se e como o consumo pode impactar nas condições de trabalho em telemarketing e na saúde dos trabalhadores desse setor e propor sugestões para harmonizar interesses sociais e econômicos, à luz da política de promoção dos direitos humanos fundamentais;

e) Investigar se há outra(s) atividade(s) assemelhada(s) ao telemarketing em relação à organização do trabalho, sujeitas à precarização das condições laborais e ao comprometimento do estado de saúde dos trabalhadores. 


\section{MÉTODO}

No campo do Direito, a metodologia científica se restringe predominantemente a uma abordagem dogmática por meio do método de pesquisa bibliográfica, sendo raros os estudos que se aventuram pelo árduo caminho da metodologia empírica. A questão metodológica é pouco enfrentada, embora seja de suma importância apontar o caminho planejado e palmilhado pelo pesquisador na busca da satisfação dos objetivos propostos, ou seja, a linha de raciocínio adotada no processo de pesquisa, seja em uma monografia, dissertação, tese ou artigo científico.

Aponta Julia Maurmann Ximenes ${ }^{8}$ que:

A pesquisa em Direito é frequentemente alvo de críticas no campo científico e de debate sobre sua cientificidade no próprio campo jurídico. Muitas destas críticas advém do fato de que a pesquisa em Direito se restringe muito a uma abordagem dogmática, se concentrando demasiadamente na produção da análise da norma, sem problematizar as diferentes temáticas jurídicas, sem relacioná-la com outras áreas do saber, sem analisar os impactos da norma e o desempenho dos diferentes atores jurídicos, como o Poder Judiciário, os advogados, o Ministério Público.

Não obstante a adoção do método de pesquisa bibliográfica e a abordagem dogmática também empregada, sobretudo através do exame da legislação atinente ao tema em estudo, optou-se pela realização de uma pesquisa empírica.

Enquanto a pesquisa bibliográfica contribui para a obtenção de dados, informações sobre o tema ${ }^{9}$ e opiniões similares ou divergentes sobre o problema pesquisado através do exame do conteúdo disposto na literatura ${ }^{10}$, a metodologia empírica visa ao aprofundamento do assunto, o exame dos impactos jurídicos no contexto abordado e a sua relação com outras áreas do conhecimento.

\footnotetext{
${ }^{8}$ XIMENES, JULIA MAURMANN. Levantamento de dados na pesquisa em direito - a técnica da análise de conteúdo. Instituto Brasiliense de Direito Público. Disponível em: <http://www.idp.edu.br/component/docman/ doc_download/145-levantamento-de-dados-na-pesquisa-em-direito--a-tecnica-da-analise-de-conteudo >. Acesso em: 13 set. 2012.

9 ECO, Humberto. Como se faz uma tese. Tradução Gilson Cesar Cardoso de Souza. 23. ed. São Paulo: Perspectiva, 2010.

${ }^{10}$ SILVA, Edna Lúcia da; MENEZES, Estera Muszkat. Metodologia da pesquisa e elaboração de dissertação. 3. ed. rev. e atual. Florianópolis: Laboratório de Ensino a Distância da UFSC, 2001. p. 38.
} 
Embora não haja uma tradição de pesquisa empírica no campo do Direito, a adoção dessa metodologia não afasta o caráter jurídico de uma abordagem, haja vista que o empirismo não está apartado dos referenciais teóricos, pois a investigação empírica está imersa em um paradigma referencial (teórico), no qual se fundam as hipóteses sustentadas para responder a um problema jurídico ${ }^{11}$.

$\mathrm{Na}$ fase de coleta de dados, empregou-se a técnica de entrevistas por pautas com base em um roteiro semiestruturado ${ }^{12}$, cujos temas serão apresentados no tópico Materiais.

Sob o ponto de vista da forma de abordagem do problema, trata-se de uma pesquisa predominantemente qualitativa, ideal quando se busca trabalhar com descrições, comparações, interpretações dos fenômenos e atribuições de significados aos discursos dos sujeitos participantes. A análise quantitativa limitou-se apenas ao levantamento da frequência e porcentagem das respostas às questões formuladas aos consumidores participantes.

Diante da proposta de sistematizar os fatores e aspectos pessoais e ambientais que compõem o meio ambiente do trabalho e a influência desses elementos na saúde dos trabalhadores, adotou-se o método de caso, oportuno quando se procura analisar um determinado fenômeno em uma situação particular. Esse método visa à descrição detalhada do contexto (trabalhadores, empresa, estrutura organizacional, meio ambiente do trabalho, demandas, problemas, programas sociais ou sociojurídicos, etc.), permitindo apontar problemas potenciais ou efetivos ${ }^{13}$. No caso deste estudo, a situação particular é o contexto de telemarketing, que serviu como pano de fundo para a discussão da influência dos fatores/aspectos pessoais e ambientais e dos elementos macrossistêmicos na saúde dos trabalhadores daquele contexto.

Oportuno esclarecer que o método de caso não se confunde com a técnica de estudo de caso, haja vista ser o primeiro uma estratégia metodológica, e o segundo, uma

\footnotetext{
${ }^{11}$ XIMENES, JULIA MAURMANN. Levantamento de dados na pesquisa em direito - a técnica da análise de conteúdo. Instituto Brasiliense de Direito Público. Disponível em: <http://www.idp.edu.br/component/docman/ doc_download/145-levantamento-de-dados-na-pesquisa-em-direito--a-tecnica-da-analise-de-conteudo >. Acesso em: 13 set. 2012.

${ }^{12}$ GÜNTHER, Hartmut. Como elaborar um questionário. In: PASQUALI, L. (Ed.). Instrumentos psicológicos: manual prático de elaboração. Brasília, DF: LabPAM; IBAPP, 1999.

${ }^{13}$ FONSECA, Maria Hemília. Curso de metodologia na elaboração de trabalhos acadêmicos. Rio de Janeiro: Editora Ciência Moderna, 2009.

GUSTIN, Miracy Barbosa de Souza; DIAS, Maria Tereza Fonseca. (Re)pensando a Pesquisa Jurídica: teoria e prática. 2. ed. Belo Horizonte: Del Rey, 2006, 252 p.
} 
técnica didática, em que o educador explica determinado conteúdo após os educandos examinarem um caso, geralmente real, conforme explica Maria Hemília Fonseca ${ }^{14}$.

Uma visão oferecida por um único método ou técnica pode revelar apenas uma face da realidade, tornando-se aconselhável recorrer a outros métodos para suprir eventuais lacunas deixadas por uma primeira investigação do fenômeno ${ }^{15}$. Por isso, optou-se por uma abordagem multimetodológica, vantajosa não apenas dentro de uma mesma área, mas também em estudos que contemplam diferentes campos do saber, diante da possibilidade de se contemplar diversos ângulos de uma mesma realidade.

\section{Materiais}

A pesquisa bibliográfica foi elaborada através do exame de materiais já publicados, incluindo livros, teses, dissertações, artigos de periódicos, conteúdos impressos e eletrônicos veiculados jornais/revistas, entendimentos jurisprudenciais e legislação sobre o assunto. Esses materiais foram adquiridos ou consultados pelo autor em bibliotecas, sobretudo da Faculdade de Direito da Universidade de São Paulo (Capital e Ribeirão Preto), na Biblioteca Central do campus de Ribeirão Preto da Universidade de São Paulo e nas seguintes bases de dados virtuais: Banco de Dados CISDOC $^{16}$ da International Labour Organization (Organização Internacional do Trabalho); Scielo ${ }^{17}$; Google Acadêmico ${ }^{18}$; Base IUSDATA da Biblioteca da Faculdade de Direito da Universidade de São Paulo; Portal de Teses e Dissertações da Universidade de São Paulo ${ }^{19}$; entre outras.

Além da pesquisa bibliográfica, diante da opção pela metodologia empírica e pela técnica de entrevista por pautas ${ }^{20}$, foram utilizados os seguintes materiais:

\footnotetext{
${ }^{14}$ FONSECA, Maria Hemília. Curso de metodologia na elaboração de trabalhos acadêmicos. Rio de Janeiro: Editora Ciência Moderna, 2009.

${ }^{15}$ ELALI, Gleice Azambuja. Psicologia e arquitetura: em busca do locus interdisciplinar. Estudos de Psicologia, Natal, v. 2, n. 2, p. 349-362, 1997.

${ }^{16}$ Disponível em: <http://www.ilo.org/dyn/cisdoc2/cismain.search>.

17 Base de dados eletrônica nacional, que reúne considerável número de revistas da Psicologia, Saúde e Educação. Disponível em: <http://www.scielo.br>.

${ }^{18}$ Ferramenta de pesquisa de literatura acadêmica, apresentando artigos revisados por especialistas, teses, dissertações, monografias, livros, resumos e artigos de editoras acadêmicas, organizações profissionais, bibliotecas de pré-publicações, universidades e outras entidades acadêmicas. Disponível em: $<$ http://scholar.google.com.br>.

${ }^{19}$ Disponível em: <http://www.teses.usp.br/>.

${ }^{20}$ BONI, Valdete; QUARESMA, Sílvia Jurema. Aprendendo a entrevistar: como fazer entrevistas em Ciências Sociais. Revista Eletrônica dos Pós-Graduandos em Sociologia Política da UFSC, Santa Catarina, v. 2, n. 1(3), p. 68-80, 2005.
} 
1) um roteiro semiestruturado para a coleta de dados, constituído pelos seguintes temas: (a) experiência do participante com o contexto de telemarketing; (b) conhecimento e aplicabilidade da Portaria $n^{\circ}$ 9, de 30 de março de 2007, do Ministério do Trabalho e Emprego, e outras disposições normativas relacionadas ao tema do estudo; (c) existência de conflito entre o Anexo II da Norma Regulamentadora $\mathrm{n}^{\circ} 17$ (Portaria $\mathrm{n}^{\circ}$ 9, de 30 de março de 2007, do Ministério do Trabalho e Emprego) e o Decreto $\mathrm{n}^{\circ}$ 6.523, de 31 de julho de 2008, regulamentado pela Portaria $\mathrm{n}^{\circ} 2.014$, de 13 de outubro de 2008, que disciplina o Serviço de Atendimento ao Consumidor; (d) influência das políticas de harmonização da relação de consumo no meio ambiente do trabalho e seus impactos na saúde e qualidade de vida do trabalhador; (e) concepção de meio ambiente do trabalho e sua relação com a saúde e a qualidade de vida do trabalhador; e (f) críticas, dúvidas e outras considerações sobre o tema que o entrevistado entendesse pertinentes;

2) Um roteiro semiestruturado para a coleta de dados junto aos consumidores, constituídos pelas seguintes indagações: (a) qual a sua opinião sobre a qualidade e eficácia dos serviços de telemarketing?; (b) na sua opinião, qual o setor em que o serviço de telemarketing é mais crítico/precário?; e (c) aponte o(s) motivo(s) da sua satisfação ou insatisfação com os serviços de telemarketing;

3) o Termo de Consentimento Livre e Esclarecido apresentado no Apêndice A deste trabalho;

4) um gravador eletrônico para registro do áudio das entrevistas realizadas com os participantes.

\section{Participantes da pesquisa de campo}

Participaram deste estudo representantes da Magistratura do Trabalho (8 - 4 de São Paulo e 4 de Ribeirão Preto), Gestores de Recursos Humanos (6 - 3 de São Paulo e 3 de Ribeirão Preto), consumidores (50 - 25 de São Paulo e 25 de Ribeirão Preto) e o Sindicato paulista da categoria de trabalhadores em telemarketing. 
Os únicos critérios adotados para seleção dos participantes foram: enquadramento nas funções supramencionadas; familiaridade com o contexto de telemarketing, essencial diante do contexto explorado via método de caso; e a concordância em participar da pesquisa. Sob o ponto de vista da forma de abordagem do problema, por se tratar de uma abordagem qualitativa e não quantitativa, considerou-se adequada a amostra quanto ao número de participantes.

Optou-se pela pesquisa de campo nas cidades de Ribeirão Preto e São Paulo pelos seguintes motivos: (a) 60\% dos postos de trabalho em telemarketing se encontram no Estado de São Paulo ${ }^{21}$; (b) tanto a cidade de Ribeirão Preto como a de São Paulo possuem sindicato representativo da categoria; e (c) as duas cidades possuem mais de duas empresas do setor, com expressivo número de teleoperadores. Portanto, diante dessas características, considerouse que as cidades eleitas possuíam condições de contribuir com uma amostra representativa do contexto de telemarketing.

\section{Procedimento de coleta de dados}

Os participantes foram convidados (pessoalmente, por e-mail ou por contato telefônico) a participar da entrevista, realizada em data, horário e lugar previamente acordados com o pesquisador. A maioria dos participantes escolheu o próprio local de trabalho para a realização da entrevista que durou, em média, quarenta minutos. Nessa oportunidade, a cada participante foram esclarecidos os objetivos do estudo e os aspectos éticos da pesquisa.

Apenas um convidado, integrante do quadro da Magistratura do Trabalho, não respondeu ao convite que lhe fora feito por contato telefônico.

Previamente à entrevista, novamente informados sobre os objetivos da pesquisa, os participantes manifestaram sua concordância em participar do estudo, através da assinatura do Termo de Consentimento Livre e Esclarecido apresentado no Apêndice A.

A entrevista foi gravada em áudio, quando autorizada pelo participante, para posterior transcrição e análise. Apenas um participante, integrante do quadro da Magistratura

\footnotetext{
${ }^{21}$ VENCO, Selma Borghi. Centrais de atendimento: a fábrica do século XIX nos serviços do século XXI. Revista Brasileira de Saúde Ocupacional, São Paulo, v. 31, n. 114, p. 7-18, jul./dez. 2006.
} 
do Trabalho, optou pela não gravação do áudio, cujo conteúdo foi registrado por escrito pelo pesquisador durante a entrevista.

\section{Procedimentos éticos}

Todos os participantes, incluindo aqueles que participaram do estudo piloto, foram devidamente esclarecidos sobre os objetivos da pesquisa, verbalmente e por meio do Termo de Consentimento Livre e Esclarecido (Apêndice A), recebendo uma cópia do respectivo documento de compromisso ético antes do início da entrevista.

As informações fornecidas pelos participantes foram e serão utilizadas estritamente para fins científicos, incluindo uma futura publicação do trabalho e apresentação em congressos e eventos científicos, conforme constou do Termo de Consentimento Livre e Esclarecido assinado pelos participantes.

Portanto, o presente estudo está em conformidade com a Resolução no 196/96 do Conselho Nacional de Saúde, que dispõe sobre os aspectos éticos da pesquisa que envolve seres humanos, conforme os itens III e III.1, alínea "a", a seguir transcritos:

\footnotetext{
III - ASPECTOS ÉTICOS DA PESQUISA ENVOLVENDO SERES HUMANOS

As pesquisas envolvendo seres humanos devem atender às exigências éticas e científicas fundamentais.

III.1 - A eticidade da pesquisa implica em:

a) consentimento livre e esclarecido dos indivíduos-alvo e a proteção a grupos vulneráveis e aos legalmente incapazes (autonomia). Neste sentido, a pesquisa envolvendo seres humanos deverá sempre tratá-lo em sua dignidade, respeitá-lo em sua autonomia e defendê-lo em sua vulnerabilidade; (...).
}

A amostra de participantes, sobretudo quanto aos consumidores entrevistados, não compreendeu vulneráveis, legalmente incapazes, tampouco sujeitos impedidos de participar do estudo sob qualquer justificativa (pessoal, legal ou administrativa) ou que guardassem informações protegidas por sigilo. Pelo contrário, foi constituída de sujeitos esclarecidos ou investidos em funções de considerável autonomia e relevância social.

Sob o ponto de vista dos cuidados éticos, conforme especificado no Termo de Consentimento Livre e Esclarecido entregue aos participantes, foram mantidos em sigilo todos os elementos que pudessem identificá-los (nome, local de trabalho, registro da voz, etc.). Os discursos dos participantes transcritos na íntegra no corpo deste estudo foram 
apresentados identificando apenas a atuação profissional de cada sujeito, por exemplo, Magistrado do Trabalho (MT), Gestor de Recursos Humanos (RH) e Consumidor (CS). Em relação ao sindicato profissional, preservou-se a identidade da pessoa do representante sindical que participou do estudo e não da entidade, haja vista a impossibilidade de mantê-la em sigilo devido à necessidade de representatividade do contexto pesquisado, ou seja, o sindicato participante deve ser obrigatoriamente da categoria profissional dos trabalhadores em telecomunicações, a qual integram os teleoperadores.

E visando à preservação definitiva da identidade dos participantes, o arquivo de áudio das entrevistas será deletado na presença do orientador desta pesquisa, após a defesa desta tese de doutorado.

\section{Estudo piloto}

Previamente às entrevistas definitivas, realizou-se um estudo piloto, tendo por objetivo verificar possíveis falhas na elaboração das questões e a compreensão pelos participantes de cada uma das indagações apresentadas pelo pesquisador, verificando-se a necessidade ou não de alteração, acréscimo ou exclusão de perguntas, através da análise das respostas $^{22}$. Os dados colhidos nessa fase foram descartados e não houve necessidade de alteração das questões que compuseram o instrumento.

\section{Análise dos dados}

Para a análise dos dados levantados e coletados, tanto por meio de revisão bibliográfica como através das entrevistas, empregou-se a técnica de análise de conteúdo, expressivamente utilizada em abordagens qualitativas e pesquisas de campo.

Essa técnica visa à expressão de um significado e um sentido além da leitura real do texto examinado, considerando também um sentido que se encontra em segundo plano (de natureza psicológica, sociológica, política, econômica, histórica, etc.), a partir do qual se

\footnotetext{
${ }^{22}$ LAKATOS, Eva Maria; MARCONI, Marina de Andrade. Fundamentos de metodologia científica. São Paulo: Atlas, 1985.
} 
evidenciam outros significados ${ }^{23}$. Segundo Laurence Bardin, a técnica de análise de conteúdo compreende:

Um conjunto de técnicas de análise das comunicações visando obter por procedimentos sistemáticos e objetivos de descrição do conteúdo das mensagens indicadores (quantitativos ou não) que permitam a inferência de conhecimentos relativos às condições de produção/recepção (variáveis inferidas) destas mensagens. ${ }^{24}$

A técnica de análise de conteúdo permite relacionar o discurso nu dos participantes, os dados levantados por meio da pesquisa bibliográfica e as possíveis interpretações desses elementos. Possibilita responder algumas indagações, como por exemplo: Quais as causas ou antecedentes de determinada legislação, política pública ou fenômeno? Quais suas possíveis consequências?

Reforçando ainda mais a adequabilidade da técnica eleita, esclarece Julia Maurmann Ximenes que:

As hipóteses levantadas nas diferentes pesquisas jurídicas podem ser efetivamente comprovadas ou não, o que enrique o processo de construção do conhecimento científico, pois ultrapassa a pesquisa bibliográfica doutrinária. A compreensão sobre o posicionamento dos atores envolvidos no processo, as diferentes posições ocupadas e os diferentes interesses envolvidos enriquecem o levantamento de dados sobre temas que buscam problematizar a prestação jurisdicional. ${ }^{25}$

Portanto, quanto à análise realizada neste estudo, os dados coletados através da pesquisa de campo foram associados ao referencial teórico levantado por meio da revisão bibliográfica, buscando descrever o contexto examinado, comparar e interpretar os fenômenos e atribuir significados aos discursos dos participantes, buscando inferir outros sentidos (por exemplo, visão de mundo, relação entre poderes, papel dos atores sociais e do Estado, legitimidade democrática, posicionamento doutrinário, etc.).

\footnotetext{
${ }^{23}$ BARDIN, Laurence. Análise de conteúdo. Tradução Luís Antero Reto e Augusto Pinheiro. Lisboa: Edições $70,1977$.

${ }^{24}$ Ibidem, p. 44.

${ }^{25}$ XIMENES, JULIA MAURMANN. Levantamento de dados na pesquisa em direito - a técnica da análise de conteúdo. Instituto Brasiliense de Direito Público. Disponível em: <http://www.idp.edu.br/component/docman/ doc_download/145-levantamento-de-dados-na-pesquisa-em-direito--a-tecnica-da-analise-de-conteudo >. Acesso em: 13 set. 2012.
} 
No caso dos dados obtidos por meio das entrevistas com consumidores, dada sua abordagem quantitativa, trilhou-se os seguintes passos: (1) registro em uma planilha (Excel) das respostas dos participantes; (2) agrupamento das respostas por analogia de temas, segundo a técnica de análise de conteúdo ${ }^{26}$; (3) nomeação de cada categoria, por exemplo, atendimento ineficiente, que inclui as seguintes palavras ditas pelos participantes: informações incorretas, falta de autonomia dos teleoperadores para a solução de problemas, desconhecimento de procedimentos, produtos elou serviços); (4) cálculo da frequência e porcentagem de indicação de cada uma das categorias levantadas; para o cálculo da porcentagem, nas duas primeiras questões considerou-se como $100 \%$ o número de participantes e, na última questão, o número total de indicações, pelo fato da indagação permitir mais de uma resposta por sujeito.

Para verificar a possibilidade de generalização dos resultados para outra(s) atividade(s) assemelhada(s) ao telemarketing, adotou-se o método indutivo, que permite alcançar conclusões gerais a partir de aspectos factuais específicos e conhecidos ${ }^{27}$. Isto é, conforme Edna Lúcia da Silva e Estera Muszkat Menezes, "no raciocínio indutivo a generalização deriva de observações de caso da realidade concreta" 28 .

\footnotetext{
${ }^{26}$ BARDIN, Laurence. Análise de conteúdo. Tradução Luís Antero Reto e Augusto Pinheiro. Lisboa: Edições $70,1977$.

${ }^{27}$ Ibidem.

${ }^{28}$ SILVA, Edna Lúcia da; MENEZES, Estera Muszkat. Metodologia da pesquisa e elaboração de dissertação. 3. ed. rev. e atual. Florianópolis: Laboratório de Ensino a Distância da UFSC, 2001. p. 26.
} 


\section{A RESSIGNIFICAÇÃO DO TRABALHO E DO MEIO AMBIENTE DO TRABALHO: UMA PERSPECTIVA HISTÓRICO-EVOLUTIVA}

\subsection{A Revolução Industrial como um divisor de águas na história do trabalho}

Ao longo da história, os movimentos operários europeus exerceram caudalosa influência na luta por melhores condições de trabalho, sobretudo diante das sucessivas propostas de reorganização do sistema produtivo impulsionadas por interesses econômicos.

Marco inicial de significativa importância, a Revolução Industrial - tendo como berço a Inglaterra do século XVIII e, posteriormente, alastrando-se por toda a Europa iniciou um processo histórico de radical transformação social e econômica, ressignificando o entendimento de trabalho e de meio ambiente do trabalho. Como um divisor de águas, esse momento histórico é apontado pela literatura como o rebento do Direito do Trabalho, "produto da reação da classe trabalhadora ocorrida no século XIX contra a utilização sem limites do trabalho humano",29.

Manuel Castells, sociólogo espanhol, esclarece que a Revolução Industrial se expandiu progressivamente, alcançando os diversos países europeus em épocas e ritmos diferentes $^{30}$. Aponta a existência de duas Revoluções Industriais: a Revolução Industrial do carvão, do ferro, do algodão e da máquina a vapor (de fiar e de tear), ocorrida no final do século XVIII, liderada pela Inglaterra e responsável pelo desenvolvimento do Capitalismo Industrial; e a Revolução Industrial do aço, do petróleo, do motor de explosão e da eletricidade, ocorrida na segunda metade do século XIX, que se expandiu pela Europa e alcançou a América do Norte e o Japão, impulsionando o desenvolvimento do Capitalismo Financeiro $^{31}$.

Essas mudanças técnicas, econômicas e sociais desencadeadas pela Revolução Industrial, a princípio na Inglaterra do século XVIII, provocaram uma densa ruptura com o

\footnotetext{
${ }^{29}$ CASSAR, Vólia Bomfim. Direito do Trabalho. 5. ed. Niterói: Impetus, 2011. p. 12.

${ }^{30}$ CASTELLS, Manuel. A Era da Informação: economia, sociedade e cultura. Fim de milênio. v. 3. Tradução Klauss Brandini Gerhardt e Roneide Venancio Majerv. São Paulo: Paz e terra, 1999.

${ }^{31}$ CASSAR, Vólia Bomfim. Op. cit.
} 
modelo de trabalho até então conhecido ${ }^{32}$. Isso porque, enquanto na Idade Média o artesanato e a manufatura eram as formas preponderantes de produção, na Idade Moderna, a burguesia, impulsionada pelo crescimento demográfico europeu, buscava formas de aprimorar o sistema de produção e estimular o mercado de consumo.

A acumulação de capital não dependia somente do aumento da produtividade e do escoamento da produção. Era necessário também reduzir as despesas da produção, substituindo, por exemplo, a energia humana pela energia das máquinas e o trabalho do homem pelo do menor e das mulheres, “economicamente mais baratos e dóceis"33.

O progressivo desenvolvimento industrial desencadeou um novo sistema de produção, utilizando-se das forças produtivas em um novo arranjo espacial: o ambiente fabril. A substituição da força humana de trabalho pela energia motriz e do trabalho domiciliário e oficinal pelo trabalho na fábrica alterou todo o modo de viver da classe trabalhadora, através da intensificação da exploração da mão-de-obra (hierarquização, aumento do ritmo de trabalho controlado pelas máquinas, etc.), da subordinação do trabalhador (pontualidade, fixação de uma jornada de trabalho exaustiva, fiscalização do trabalho, etc.) e da expropriação da parcela intelectual do trabalho ${ }^{34}$.

Com o surgimento das indústrias, a busca por melhores salários e, consequentemente, por melhores condições de vida, passou a atrair a massa camponesa para os centros urbanos europeus. Se por um lado a mecanização do trabalho favoreceu a expansão do mercado de consumo através do aumento da produtividade e da queda dos preços das mercadorias, por outro culminou na aceleração do ritmo da produção, no adoecimento e na vulnerabilidade dos operários a acidentes de trabalho, em virtude do cansaço e da precária instrução acerca do manuseio dos maquinários. Provocou, ainda, o aumento do índice de desemprego, diante da impossibilidade de absorção de toda mão de obra disponível, justificada pela substituição da energia humana pela energia motriz.

Uma das principais mudanças desencadeadas pela industrialização implicou na separação entre ambiente de trabalho e moradia, em virtude do processo de mecanização que tornou impossível a realização do trabalho fora do ambiente fabril, onde se encontravam as

\footnotetext{
32 ROCHA, Julio César de Sá da. Direito ambiental do trabalho: mudança de paradigma na tutela jurídica à saúde do trabalhador. São Paulo: LTr, 2002.

${ }^{33}$ CASSAR, Vólia Bomfim. Direito do Trabalho. 5. ed. Niterói: Impetus, 2011. p. 15.

${ }^{34}$ RIOUX, Jean Pierre. Revolução Industrial: 1780-1880. São Paulo: Pioneira, 1975.
} 
máquinas que impunham o ritmo da produção. O ofício, antes realizado nas oficinas domiciliares, migrou para os centros industriais, estruturados sem qualquer preocupação com as condições de trabalho e sob rígida fiscalização. Surgia, então, os primeiros veios que justificariam mais tarde, com os movimentos operários, a necessidade de medidas de saúde e segurança no trabalho que freasse a sanha capitalista que ameaçava a dignidade do trabalhador.

As condições degradantes às quais eram submetidos os trabalhadores, reforçadas pela precária iluminação, ausência de segurança, má circulação de ar e jornadas diárias exaustivas, somadas às diminutas condições de vida no cenário urbano assolado por epidemias generalizadas e ausência de condições mínimas de higiene, colaboraram para a precarização do trabalho, sem qualquer condição de dignidade dentro e fora dos muros das fábricas. Esclarece Elisângela Magela Oliveira que os operários foram condicionados a seguir o ritmo da máquina a vapor, cumprindo extensas jornadas de trabalho já não mais limitadas pelo anoitecer, em razão da utilização da iluminação a gás ${ }^{35}$. Vólia Bomfim Cassar denuncia a submissão dos operários a uma jornada de trabalho exaustiva, de 16 horas, e à exploração perversa da mão de obra operária ${ }^{36}$.

De maneira sintética, a insatisfação da classe operária com as condições de trabalho, que refletiam nas condições de vida nos centros urbanos, favoreceu a organização dos trabalhadores e a luta por melhores condições de trabalho, evidenciando a inviabilidade da manutenção dos interesses econômicos caso fosse mantido o modelo instaurado pela Revolução Industrial. Os movimentos operários, alguns mais radicais, cuidaram de estabelecer as primeiras, porém ainda rasas, reivindicações sociais. Era o início das diferenças entre capital e trabalho.

\subsection{Taylorismo, Fordismo e Toyotismo: a reorganização do processo produtivo e seus impactos no meio ambiente do trabalho}

Diversas propostas de reorganização do processo produtivo impactaram no meio ambiente do trabalho, pois interviram em seus mais diversos aspectos relacionados à organização e às condições de trabalho.

\footnotetext{
35 OLIVEIRA, Elisângela Magela. Transformações no mundo do trabalho na Revolução Industrial aos nossos dias. Caminhos de Geografia, Uberlândia, v. 5, n. 11, p. 84-96, 2004.

${ }^{36}$ CASSAR, Vólia Bomfim. Direito do Trabalho. 5. ed. Niterói: Impetus, 2011.
} 
No início do século $\mathrm{XX}$, a reestruturação do processo produtivo instituído pela Revolução Industrial foi revista pelo modelo taylorista-fordista que, de uma maneira geral, ressignificou o modo de produção através da reinvenção da organização do trabalho. Os impactos provocados por esse modelo alcançaram o meio ambiente do trabalho, evidenciando a interdependência entre economia, trabalho, ambiente e saúde.

A saber, o taylorismo - método de organização científica do trabalho proposto pelo engenheiro norte-americano Frederick Winslow Taylor - instituiu uma nova concepção de organização do trabalho por meio do controle dos movimentos das máquinas e dos trabalhadores, com a finalidade de sistematizar a produção, majorar a produtividade, economizar tempo e suprimir gastos desnecessários no processo produtivo ${ }^{37}$.

O modelo taylorista, mais tarde conhecido no Brasil por Organização Científica do Trabalho, propôs a racionalização e a intensificação do processo produtivo, fragmentandoo em tarefas especializadas e repetitivas ${ }^{38}$. Sustentava Taylor que os operários perdiam tempo demais para encontrar formas de desacelerar o trabalho, o que o levou a cronometrar o tempo despendido para cada etapa da produção; cada operário era especialista no seu próprio ofício e deveria realizá-lo no menor tempo possível. Harry Braverman adverte que, na prática, Frederick Winslow Taylor "tendia a definir este nível de atividade em um limite extremo, escolhendo um ritmo que apenas alguns podiam manter, e mesmo assim sob força” ${ }^{39}$.

Ainda no início do século XX, período em que os bens de consumo tornavam-se mais acessíveis em virtude do aparente crescimento econômico ${ }^{40}$, o fortalecimento do capitalismo dependia da expansão do mercado consumidor. Portanto, mais do que aumentar a produtividade, era preciso reduzir o preço final dos produtos para estimular o consumo, o que somente seria possível com a reinvenção do processo produtivo.

Aperfeiçoando o padrão taylorista de organização do trabalho, Henry Ford propôs a reinvenção do processo produtivo baseada no aumento da produtividade por meio do

\footnotetext{
${ }^{37}$ SILVA, Airton Marinho da. A regulamentação das condições de trabalho no setor de teleatendimento no Brasil: necessidades e desafios. 2004. 129 f. Dissertação (Mestrado em Saúde Pública) - Faculdade de Medicina, Universidade Federal de Minas Gerais, Belo Horizonte, 2004.

38 NAVARRO, Vera Lúcia. Trabalho, subjetividade e lazer: estranhamento, fetichismo e reificação no capitalismo global. In: PADILHA, Valquiria. (Org). Dialética do Lazer. São Paulo: Cortez, 2006. p. 50-74.

39 BRAVERMAN, Harry. Trabalho e capital monopolista: a degradação do trabalho no século XX. Tradução Nathanael C. Caixeiro. 3. ed. Rio de Janeiro: Guanabara, 1987. p. 91.

${ }^{40}$ A euforia econômica registrada no início do século XX não alcançou sequer o final da década de 20, sendo um dos motivos que desencadearam a crise de 1929, com a quebra da Bolsa de Valores de Nova York; os impactos dessa crise, também conhecida como "A Grande Depressão", alcançaram ainda os países europeus e o Brasil, que tinha os Estados Unidos como seu maior mercado para exportação de café.
} 
controle dos movimentos das máquinas e dos operários para a execução das tarefas no menor tempo possível; introduziu a esteira mecânica no sistema de produção, cujo mecanismo, ininterrupto, impunha o ritmo de trabalho. Com a introdução da esteira no processo produtivo, cada tarefa dependia da agilidade e da qualidade do trabalho realizado pelo operário envolvido na etapa anterior, pois "uma linha rígida de produção articulava os diferentes trabalhos, tecendo vínculos entre as ações individuais das quais a esteira fazia as interligações, dando o ritmo e o tempo necessários para a realização das tarefas" ${ }^{41}$.

O modelo fordista ainda cuidou de instituir uma nova política salarial escorada no cumprimento das regras estabelecidas e dos ritmos de produção, visando ao estímulo do consumo até mesmo no interior das fábricas, ao tornar seus operários capazes de adquirir os bens que produziam.

Ricardo Antunes esclarece que o binômio taylorismo-fordismo vigorou durante quase todo o século XX, sobretudo a partir da segunda década, baseando-se na "produção em massa de mercadorias, que se estruturava a partir de uma produção mais homogeneizada e enormemente verticalizada" ${ }^{42}$.

A despeito de toda revolução do sistema produtivo decorrente desses modelos de organização, a intensificação das formas de exploração e a supressão da dimensão intelectual do ofício, concentrada tão somente na gerência científica, comprometeram as condições de trabalho da classe operária, fazendo dela um componente instrumental sem subjetividade. Essa expropriação intensificada era sintetizada em uma atividade repetitiva e desprovida de sentido $^{43}$, empregando uma clara dicotomia entre trabalho concebido ou planejado e trabalho executado, haja vista o planejamento da atividade incumbir aos hierarquicamente superiores, cabendo a simples execução aos operários, limados de qualquer pensamento conceitual sobre aquilo que executavam.

Uma vez ausente o pensamento conceitual sobre o trabalho, nada se pensava, nada se elaborava e nada se construía. E é justamente esse pensamento conceitual sobre o trabalho que diferencia o ser humano dos outros animais. Na visão de Karl Marx, o trabalho pertence exclusivamente ao ser humano, pois mesmo que uma aranha execute operações semelhantes a

\footnotetext{
${ }^{41}$ ANTUNES, Ricardo. Os sentidos do trabalho: ensaio sobre a afirmação e a negação do trabalho. São Paulo: Boitempo Editorial, 1999. p. 37.

${ }^{42}$ Ibidem, p. 36.

${ }^{43}$ Ibidem, p. 41.
} 
de um tecelão e uma abelha envergonhe o melhor dos arquitetos na construção dos favos de sua colmeia, o que distingue o esforço desses animais do trabalho humano é que o resultado alcançado ao fim do processo já existia desde o início na imaginação do trabalhador, portanto, idealmente ${ }^{44}$. Essa complexidade do trabalho humano, cerceada pelos modelos produtivos em análise, assim é compreendida por Karl Marx:

Ele não apenas efetua uma transformação da forma da matéria natural; realiza, ao mesmo tempo, na matéria natural seu objetivo, que ele sabe que determina, como lei, a espécie e o modo de sua atividade e ao qual tem de subordinar sua vontade. E essa subordinação não é um ato isolado. Além do esforço dos órgãos que trabalham, é exigida a vontade orientada a um fim, que se manifesta como atenção durante todo o tempo de trabalho, e isso tanto mais quanto menos esse trabalho, pelo próprio conteúdo e pela espécie e modo de sua execução, atrai o trabalhador, portanto, quanto menos ele o aproveita, como jogo de suas próprias forças físicas e espirituais. Os elementos simples do processo de trabalho são a atividade orientada a um fim ou o trabalho mesmo, seu objeto e seus meios. ${ }^{45}$

Noutro giro, se por um lado essas propostas de reestruturação da produção comprometeram as condições de trabalho ao cercear a subjetividade dos trabalhadores, por outro, foram eficazes para o desenvolvimento de um mercado de consumo, principalmente ao reamoldar a organização do trabalho visando à redução dos custos do processo produtivo.

Embora possa parecer que os termos condições de trabalho e organização do trabalho são análogos, Cristophe Dejours ${ }^{46}$ aponta que, por condições de trabalho, deve-se entender as características do conteúdo ergonômico, nas suas dimensões físicas, químicas, biológicas, condições de higiene, segurança e características do posto de trabalho, que atingem a saúde física do trabalhador; e por organização do trabalho, o conteúdo subjetivo do atrelado ao conteúdo material (instrumentos de operação, características da tarefa, conteúdo simbólico da prática, etc.), apresentando estreita relação com a saúde psíquica do trabalhador.

Em síntese, as condições de trabalho são relacionadas à saúde física e a organização do trabalho é relacionada à saúde psíquica do trabalhador.

\footnotetext{
${ }^{44}$ MARX, Karl. O capital: crítica da economia política. Tradução Regis Barbosa e Flávio R. Kothe. v.1, t. 1. São Paulo: Nova Cultural, 1996. p. 297-298.

${ }^{45}$ Ibidem.

${ }^{46}$ DEJOURS, Cristophe. A loucura do trabalho: estudo de Psicopatologia do Trabalho. 5.ed. São Paulo: Cortez, 1992.
} 
Portanto, evidente que a rígida organização do trabalho dos modelos taylorista e fordista, marcada pela expropriação intelectual e pela exploração intensificada dos operários para o aumento da produção e satisfação da demanda consumerista, comprometeram as condições às quais estavam submetidos os operários. Esclarece Ricardo Antunes ${ }^{47}$ que, no final dos anos 60, os trabalhadores passaram a questionar a organização do trabalho imposta pelo método taylorista-fordista de produção, conferindo-se ocorrências de absenteísmo, fuga do trabalho, alta rotatividade, greves parciais e até mesmo ações coletivas para a tomada do poder sobre o processo do trabalho.

Em meados dos anos 70, período crítico de mudanças econômicas, com a diversificação do mercado e o sucateamento dos equipamentos operados individualmente, "o sistema de produção em massa ficou muito rígido e dispendioso para as características da nova economia" 48 . Com a introdução de novos métodos de trabalho, o fordismo entrou em declínio, cedendo espaço para o toyotismo (ou modelo japonês), por alguns considerado um modo original de gerenciamento do processo produtivo flexível pautado na cooperação entre gerentes e trabalhadores, no controle rígido de qualidade, na capacitação multifuncional e na proporcionalidade entre produção e demanda ${ }^{49}$.

Essa ideia de surgimento de uma "nova organização do trabalho" não é unânime e vem sendo contestada por recentes pesquisas que atribuem às mudanças do período que afetaram o mundo do trabalho não apenas às novas tecnologias e ao processo de desenvolvimento organizacional toyotista, mas também a fatores históricos e geográficos da época ${ }^{50}$.

O modelo toyotista originou-se no Japão pós-45, como uma forma de organização do trabalho para a expansão e consolidação do capitalismo industrial. Ricardo Antunes ${ }^{51}$ evidencia os seguintes traços do modelo toyotista: (a) produção variada e heterogênea vinculada à demanda e ao atendimento individualizado do mercado consumidor; (b) trabalho em equipe com multivariedade de funções; (c) processo produtivo flexível, alterando a relação operário-máquina, diante da possibilidade de um mesmo operário manejar simultaneamente

\footnotetext{
${ }^{47}$ ANTUNES, Ricardo. Os sentidos do trabalho: ensaio sobre a afirmação e a negação do trabalho. São Paulo: Boitempo Editorial, 1999.

${ }^{48}$ CASTELLS, Manuel. A Era da Informação: economia, sociedade e cultura. Fim de milênio. v. 3. Tradução Klauss Brandini Gerhardt e Roneide Venancio Majerv. São Paulo: Paz e terra, 1999. p. 176.

${ }^{49}$ FRAGA, Alexandre. Da rotina à flexibilidade: análise das características do fordismo fora da indústria. Revista Habitus: IFCS/UFRJ, Rio de Janeiro, v. 3, n. 1, p. 36-43, 2006.

${ }^{50}$ ANTUNES, Ricardo. Op. cit.

${ }^{51}$ Ibidem.
} 
diversas máquinas; (d) subcontratação de trabalhadores, transferindo-se parte das atividades para outras empresas; (e) melhor aproveitamento do tempo de produção; e (f) estoque mínimo, com a reposição de peças e produtos através do sistema kanban ${ }^{52}$.

Otavio Pinto e Silva refere-se ao toyotismo como um dos modelos que surgiram no período pós-fordismo, “como método de organização que se caracterizou pelo trabalho em equipe, desenvolvido com uma grande rotação dos trabalhadores pelos postos de trabalho, conforme as necessidades de demanda" ${ }^{, 53}$, evidenciando o entrelaçamento das condições e da organização do trabalho com a demanda consumerista.

Essas transformações, na análise de Ricardo Antunes ${ }^{54}$, decorreram da própria necessidade de estancar as lutas sociais e abrandar a crise estrutural capitalista que se reergueu apoiada em um processo de retomada da acumulação e valorização global do capital, que se estende até hoje, cuja proposta assentava-se na seguinte lógica: redução do tempo de vida útil dos produtos para o aumento do consumo que, por corolário, dependia do aumento da produção ${ }^{55}$. O desenvolvimento de "tecnologias de curta duração" é também apontado por Antonio Rodrigues de Freitas Júnior como estratégia para o enfrentamento das crises inauguradas na década de $70^{56}$.

Para Otavio Pinto e Silva, as características do sistema produtivo toyotista ainda se encontram preservadas no mundo ocidental, com as devidas adaptações ${ }^{57}$, como bem examina Antonio Rodrigues de Freitas Júnior ao destrinchar uma política de recursos humanos contemporânea bastante comum ao modelo instaurado pelo toyotismo:

(...) em lugar das grandes concentrações fabris, a nova empresa deve se preocupar com a contínua otimização do pessoal ocupado e com a terceirização das atividades não estratégicas, oferecendo remuneração

\footnotetext{
${ }^{52}$ Para melhor elucidar o sistema kanban, Ricardo Antunes explica que na Toyota o ritmo de trabalho era estabelecido pelo sistema de luzes (cor verde, laranja e vermelha); a luz verde indica funcionamento normal, a luz laranja impõe intensidade máxima ao ritmo produtivo e a luz vermelha acusa problemas no processo produtivo e a necessidade de redução do ritmo de trabalho - In ANTUNES, Ricardo. Op. cit.

53 SILVA, Otavio Pinto e. Subordinação, Autonomia e Parassubordinação nas Relações de Emprego. São Paulo: LTr, 2004. p. 114.

${ }^{54}$ ANTUNES, Ricardo. Os sentidos do trabalho: ensaio sobre a afirmação e a negação do trabalho. São Paulo: Boitempo Editorial, 1999.

${ }^{55}$ Ricardo Antunes cita alguns exemplos: o tempo médio de vida útil para os automóveis, cuja durabilidade é cada vez menor e a desvalorização cada vez mais veloz; os fast foods que produzem lanches sob o ritmo seriado, sem qualquer qualidade ou preocupação com a saúde do consumidor; os softwares que se tornam obsoletos rapidamente, tornando-se incompatíveis com novos computadores, requerendo pronta substituição por versões atualizadas; aparelhos de celulares que se tornam obsoletos e "demodês" em três meses; etc. - ANTUNES, Ricardo. Op. cit.

${ }^{56}$ FREITAS JR., Antonio Rodrigues de. Direito do trabalho na era do desemprego. São Paulo: LTr, 1999. p. 99.

${ }^{57}$ SILVA, Otavio Pinto e. Op. cit.
} 
seletivamente atraente segundo critérios de compromisso com os objetivos da empresa e de produtividade individual ou setorial ${ }^{58}$.

O incremento tecnológico da automação e da microeletrônica proposto pelo modelo toyotista e aprimorado pela Revolução das Tecnologias da Informação e da Comunicação, a seguir abordada, viria intensificar as condições de exploração da força humana de trabalho, possibilitando que um menor contingente de trabalhadores alcançasse altos índices de produtividade, favorecendo o consumo pela massa. Evidentemente, essa recente reestruturação do processo produtivo também impactou no meio ambiente do trabalho, ao intervir no modo da prestação laboral.

\subsection{A contemporânea Revolução das Tecnologias da Informação e Comunicação e seus impactos no mundo do trabalho}

Os diversos movimentos operários e as múltiplas propostas de reorganização do processo produtivo vistas anteriormente influenciaram insidiosamente nas condições de trabalho, porém, não foram suficientes para pacificar os interesses econômicos e sociais. Com o aparecimento de novas profissões e novas formas de prestação para atender aos anseios de uma sociedade que se reinventa todos os dias, ainda reclama o trabalho e seus sujeitos novas regras de organização e de tutela.

Além de alterar hábitos e comportamentos, essa constante reinvenção também exerce impactos no conteúdo organizacional e, consequentemente, no meio ambiente do trabalho, conforme visto nas linhas anteriores. É o caso da contemporânea Revolução das Tecnologias da Informação e Comunicação, impulsionada pelo recente processo de globalização da economia, que provocou algumas descobertas tecnológicas no início do século XX, responsáveis pela reestruturação produtiva e por instituir novas formas de trabalho $^{59}$ através da sofisticação tecnológica e, ao mesmo tempo, extinguir outras

\footnotetext{
${ }^{58}$ FREITAS JR., Antonio Rodrigues de. Direito do trabalho na era do desemprego. São Paulo: LTr, 1999.

${ }^{59} \mathrm{O}$ teletrabalho é um exemplo emblemático de nova forma de trabalho instituído pela sofisticação tecnológica; é definido por Otavio Pinto e Silva como modalidade laboral caracterizada pela "conjugação de dois elementos, a saber: o emprego de instrumentos telemáticos e a distância entre o local em que se presta o trabalho e aquele em que este é utilizado". SILVA, Otavio Pinto e. Op. cit., p. 135.
} 
preexistentes $^{60}$. Dentre essas descobertas tecnológicas, aponta Otavio Pinto e Silva "a crescente automação, os novos tipos de materiais usados em todos os setores da produção, as imensas facilidades obtidas no campo das comunicações" ${ }^{\prime 61}$.

Para Jacob Gorender ${ }^{62}$, a recente revolução tecnológica, sobretudo na informática e telecomunicações, decorre das transformações no sistema capitalista mundial, cujos efeitos são percebidos na organização do trabalho, nos métodos de produção, nas relações de trabalho e na política financeira dos governos.

Nessa mesma direção, Manuel Castells adverte que as novas tecnologias, incremento do final da década de 90 , foram fundamentais para a reestruturação das empresas, tornando possível o aumento da produtividade e a redução do custo da produção ${ }^{63}$. Aponta, ainda, que além dos impactos dessa reestruturação, os aspectos institucionais, culturais, as políticas empresariais e governamentais também foram fundamentais para a sustentação da empregabilidade, produzindo impactos na relação de trabalho. Isso reforça a tese construída neste estudo acerca da interdependência sistêmica, que mais a frente será melhor explorada.

Diante dessas inovações tecnológicas, atestam Silvia Maria Manfredi e Solange Bastos a diversidade de estudos feitos no campo da sociologia, da economia, da educação, da saúde e da psicologia, entre outras áreas, no sentido de aprofundar o estudo dos processos de modernização técnica e organizacional ${ }^{64}$, que tem acompanhado o recente processo de globalização da economia capitalista e os impactos destas transformações sobre o trabalho e, evidentemente, sobre o direito do trabalho ${ }^{65}$.

Se por um lado essa sofisticação tecnológica possibilitou modificar o conteúdo organizacional do trabalho, permitindo, por exemplo, a simplificação do processo produtivo e do tempo de execução das tarefas, em revés, tornou o labor mais intenso, compacto e

\footnotetext{
${ }^{60}$ SILVA, Otavio Pinto e. Subordinação, Autonomia e Parassubordinação nas Relações de Emprego. São Paulo: LTr, 2004.

${ }^{61}$ SILVA, Otavio Pinto e. Op. cit.

${ }^{62}$ GORENDER, Jacob. Globalização, tecnologia e relações de trabalho. Estudos Avançados, São Paulo, v. 11, n. 29, p. 311-361, 1997.

${ }^{63}$ CASTELLS, Manuel. A Era da Informação: economia, sociedade e cultura. Fim de milênio. v. 3. Tradução Klauss Brandini Gerhardt e Roneide Venancio Majerv. São Paulo: Paz e terra, 1999.

${ }^{64}$ MANFREDI, Silvia Maria; BASTOS, Solange. 1998, Propostas e experiências de formação profissional no âmbito das organizações de trabalhadores. Cedes Unicamp, maio 1998. Disponível em: <http://www.cedes.unicamp.br/pesquisa/artigos/MANFREDI/indice.html>. Acesso em: 2 nov. 2011.

${ }^{65}$ SILVA, Otavio Pinto e. Op. cit.
} 
amplamente controlado $^{66}$, instituindo novos espaços, novas demandas, novas regras de produção, sociabilidade e sobrevivência, bem como novas formas de agir, de pensar e de viver $^{67}$.

Diante dessas mudanças factuais, conclui Otavio Pinto e Silva que "o direito do trabalho deve se adaptar ao mundo de hoje, que não é mais o mesmo de quando foi

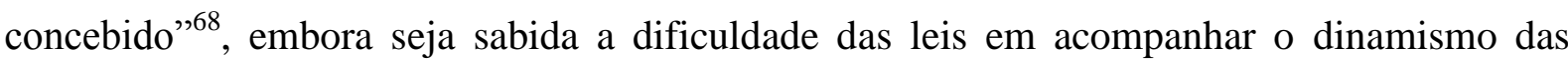
mudanças sociais.

Além dos impactos de natureza econômica provocados pela globalização da economia e pela Revolução das Tecnologias da Informação e Comunicação, a saúde (física e psíquica), segurança e qualidade de vida do trabalhador - assuntos que nunca deixaram a pauta social - também convidaram diferentes atores do contexto laboral a rediscutir a organização, as condições de trabalho e sua relação com o direito fundamental a um trabalho digno, incólume e seguro, previsto, no Brasil, a partir da Constituição Federal da República de 1988, em seus artigos $6^{\circ}$ e $7^{\circ}$. Por isso, assevera Ari Possidonio Beltran" ${ }^{69}$, que "a internacionalização da economia é fenômeno que hoje não pode ser desprezado, sobretudo quanto ao seu impacto no mundo jurídico, e em especial (...), nas relações de trabalho", evidenciando a interdependência entre interesses econômicos e sociais e seus impactos no universo do trabalho.

\footnotetext{
${ }^{66}$ MOURA, Mauro Azevedo de. Novas tecnologias. Revista Brasileira de Saúde Ocupacional, São Paulo, v. 21, n. 79, p. 63-75, jul./set. 1993.

67 NICOLACI-DA-COSTA, Ana Maria. Revoluções tecnológicas e transformações subjetivas. Psicologia: Teoria e Pesquisa, Brasília, v. 18, n. 2, p. 193-202, maio/ago. 2002.

68 SILVA, Otavio Pinto e. Subordinação, Autonomia e Parassubordinação nas Relações de Emprego. São Paulo: LTr, 2004.

${ }^{69}$ BELTRAN, Ari Possidonio. Os impactos da integração econômica no direito do trabalho: globalização e direitos sociais. São Paulo: LTr, 1998. p. 21.
} 


\section{OS IMPACTOS ECONÔMICOS DO CONSUMO NO MUNDO DO TRABALHO}

\subsection{O surgimento da sociedade do consumo e seus impactos no mundo do trabalho}

O resgate histórico-evolutivo empregado no capítulo anterior aborda, progressivamente, o contexto e os elementos que impulsionaram o surgimento e a expansão da sociedade de consumo, especialmente, em princípio, a industrialização e, por conseguinte, a concepção e o desenvolvimento do modelo de produção em série, também chamado de standartização ou homogeneização da produção.

Busca-se, portanto, evidenciar que o meio ambiente do trabalho é influenciado por diversos aspectos macrossistêmicos, que estabelecem o padrão para as estruturas e atividades no plano laboral.

Todavia, antes de tratar dos impactos da sociedade do consumo no mundo do trabalho, sendo essa uma das propostas do presente estudo, há que se dedicar algum esforço para a compreensão do surgimento dessa sociedade e do movimento de defesa do consumidor.

Marcelo Gomes Sodré explica que "a sociedade de consumo é o lado da demanda da revolução industrial, é um dos vértices da estrutura econômica da sociedade industrial moderna" ${ }^{, 70}$. Não se trata de uma classe social, pois todas as classes integram essa sociedade: trabalhadores, não-trabalhadores (desempregados e incapazes), produtores, etc.

Rizzato Nunes $^{71}$ adverte que, antes do estudo da Lei $n^{\circ} 8.078$ de 11 de setembro de 1990, o Código de Defesa do Consumidor, é importante conhecer os fundamentos que lhe deram origem, registrados nos antecedentes históricos e, sobretudo, no contexto do surgimento e desenvolvimento da sociedade do consumo. Para o jurista, "entender a Lei $\mathrm{n}^{\circ}$ 8.078 implica, portanto, considerar um problema de memória"72.

\footnotetext{
${ }^{70}$ SODRÉ, Marcelo Gomes. A construção do Direito do Consumidor: um estudo sobre as origens das leis principiológicas de defesa do consumidor. São Paulo: Atlas, 2009. p. 9.

${ }^{71}$ NUNES, Rizzato. Curso de Direito do Consumidor. 7. ed. São Paulo: Saraiva, 2012.

72 Ibidem, p. 41.
} 
O período pós-Revolução Industrial é visto como o marco inicial da sociedade do consumo. O surgimento das indústrias impulsionou o crescimento demográfico europeu, alterando a concentração da massa camponesa dos campos para os centros urbanos. Para Eric Hobsbawm, a mudança social mais importante e de mais longo alcance da segunda metade do Século XX, responsável pela ruptura com o mundo passado, é a morte do campesinato ${ }^{73}$.

Esse crescimento populacional gerou o aumento da demanda e, por corolário, uma possibilidade do aumento da oferta, levando as indústrias a buscar um modelo produtivo que propiciasse produzir mais para atender a essa procura. Já não bastava apenas substituir a produção artesanal pela produção mecanizada, era preciso reorganizar o sistema produtivo.

Se o marco inicial da sociedade do consumo foi o período posterior a Revolução Industrial, a criação da chamada produção em série pela reorganização do processo produtivo foi o marco da expansão dessa sociedade consumerista. Conforme já abordado no Capítulo anterior, o parcelamento das tarefas, o controle do ritmo de trabalho, a diminuição dos custos da produção e, consequentemente, do preço final do produto, favoreceu o aumento da oferta buscado pela indústria.

Esse sistema de produção, inaugurado pelo modelo taylorista e sucessivamente aprimorado pelos modelos fordista e toyotista, sobreviveu à passagem do Século XIX para o Século XX, enfrentando períodos de forte recessão à época da Primeira Guerra Mundial. Superado esse período histórico, a partir da Segunda Guerra Mundial a produção se solidificou e cresceu em níveis extraordinários com a sofisticação tecnológica impulsionada pelo surgimento da tecnologia de ponta, pelo fortalecimento da informática e pelo incremento das telecomunicações ${ }^{74}$. Era o início da contemporânea Revolução das Tecnologias da Informação e Comunicação.

Pondera Marcelo Gomes Sodré que existe uma efervescente discussão internacional sobre o momento em que se iniciou a sociedade de consumo ${ }^{75}$, porém, ao que tudo indica, esse surgimento ocorreu entre os séculos XVIII e XIX, tendo como atores sociais produtores, trabalhadores e consumidores.

\footnotetext{
${ }^{73}$ HOBSBAWM, Eric. A era dos extremos: o breve século XX. 2. ed. São Paulo: Companhia das Letras, 1997. p. 284.

${ }^{74}$ NUNES, Rizzato. Curso de Direito do Consumidor. 7. ed. São Paulo: Saraiva, 2012.

75 SODRÉ, Marcelo Gomes. A construção do Direito do Consumidor: um estudo sobre as origens das leis principiológicas de defesa do consumidor. São Paulo: Atlas, 2009.
} 
O relatório do Programa das Nações Unidas para o Desenvolvimento (PNUD) de 1998 aponta que o Século XX foi o século do consumo ${ }^{76}$. Em 1900, a despesa mundial com consumo era de 1,5 bilhões de dólares americanos, ao passo que em 1975, era de 12 bilhões e, ao final do século, em 1998, de 24 bilhões. Segundo Eric Hobsbawn, “o que antes era luxo tornou-se o padrão de conforto desejado", tornando-se possível para os cidadãos médios viverem como apenas os muito ricos haviam vivido ${ }^{77}$.

Todavia, o mesmo relatório do PNUD de 1998 aponta a desigualdade do crescimento e da distribuição de benefícios, como alojamento com água quente e fria, aquecimento e eletricidade, transporte, lazer, desporto, férias, etc.; problemas ainda muito presentes no Século XXI.

Por sua vez, o movimento de defesa do consumidor originou-se a partir de meados do Século XX, assentado na luta pelo acesso ao consumo de bens seguros e a garantia da informação plena a respeito dos produtos e serviços colocados no mercado. Evidentemente, esse conflito ainda existe e justifica as políticas de harmonização da relação de consumo abordadas neste trabalho, ao passo que, segundo elucida Marcelo Gomes Sodré, na atual sociedade da informação, soma-se aos antigos conflitos a luta pela garantia de informação que assegure o direito de opção ${ }^{78}$.

As primeiras entidades de defesa do consumidor surgiram em resposta aos conflitos sociais da década de 20 do Século XX e foram impulsionadas pela expansão da sociedade do consumo no pós-guerra, fortalecendo-se nos países desenvolvidos na década de 70, depois da Segunda Guerra Mundial ${ }^{79}$. Quanto ao contexto, esclarece Eric Hobsbawm:

A economia mundial, portanto, crescia a uma taxa explosiva. Na década de 1960, era claro que jamais houvera algo assim. A produção mundial de manufaturas quadruplicou entre o início da década de 1950 e o início da década de 1970 e, o que é ainda mais impressionante, o comércio mundial de produtos manufaturados aumentou em dez vezes. ${ }^{80}$

76 ORGANIZAÇÃO DAS NAÇÕES UNIDAS. Relatório do Programa das Nações Unidas para o Desenvolvimento: Consumo para o Programa Humano. Lisboa: Trivona, 1998.

${ }^{77}$ HOBSBAWM, Eric. A era dos extremos: o breve século XX. 2. ed. São Paulo: Companhia das Letras, 1997. p. 259.

78 SODRÉ, Marcelo Gomes. A construção do Direito do Consumidor: um estudo sobre as origens das leis principiológicas de defesa do consumidor. São Paulo: Atlas, 2009.

${ }^{79}$ ALMEIDA, Carlos Ferreira de. Os direitos do consumidor. Coimbra: Almedina, 1982.

${ }^{80}$ HOBSBAWM, Eric. A era dos extremos: o breve século XX. Op. cit. 
Para Marcelo Gomes Sodré, em 1936 surgiu nos Estados Unidos a primeira organização de âmbito nacional típica de proteção dos consumidores, a Consumers Union, ainda existente ${ }^{81}$. Em 1950, outras organizações surgiram em países desenvolvidos, sobretudo europeus (Inglaterra, Holanda, Bélgica, França, Noruega e Alemanha Ocidental), despertando o interesse de alguns países em desenvolvimento, como a Índia e o Paquistão. Já no início da década de 60, chamada de época de ouro do movimento de defesa do consumidor, foi organizado o primeiro movimento internacional das entidades de defesa em Haia, a Primeira Conferência Internacional a respeito de Testes de Produtos, que resultou na criação da International Organization of Consumers Union, em $1^{\circ}$ de abril de 1960, atual Consumers International, hoje composta por mais de 200 entidades-membros de mais de 110 países $^{82}$.

Dois anos mais tarde, em 15 de março de 1962, o Presidente John F. Kennedy encaminhou ao Congresso dos Estados Unidos uma mensagem com os seguintes dizeres:

Ao Congresso dos Estados unidos:

Consumidores, por definição, somos todos nós. Eles são os maiores grupos econômicos na economia, afetando e sendo afetados por quase toda decisão econômica pública e privada. Os consumidores respondem por dois terços de tudo gasto na economia. Mas eles são o único grupo importante na economia que não são efetivamente organizados cuja opinião frequentemente não é ouvida. $^{83}$

Este discurso, tido como a primeira enunciação política sobre o assunto, ainda apresentou a necessidade de programas governamentais para o atendimento dos seguintes direitos básicos dos consumidores apontados no documento: segurança, informação, livre escolha e participação nas decisões que lhes dizem respeito ${ }^{84}$.

A aprovação das primeiras leis de defesa do consumidor demorou a acontecer, enfrentando um processo lento até mesmo nos países desenvolvidos. Aliás, o direito é uma ciência póstuma por natureza, pois os fatos surgem sempre antes do direito. E não haveria de ser diferente, pois o direito é feito para e conforme a sociedade, olhando (ou devendo olhar) para o contexto e para os anseios nele imprimidos.

\footnotetext{
${ }^{81}$ SODRÉ, Marcelo Gomes. A construção do Direito do Consumidor: um estudo sobre as origens das leis principiológicas de defesa do consumidor. São Paulo: Atlas, 2009.

${ }^{82}$ Ibidem.

${ }^{83}$ Ibidem, p. 23.

${ }^{84}$ Ibidem.
} 
É com base no contexto da explosão da sociedade de consumo nos países desenvolvidos, no início do Século XX e, sobretudo, pela atuação das entidades de defesa dos consumidores e da manifestação individual desses atores, que se iniciou lentamente a construção do que viria a ser chamado de Direito do Consumidor, por impulso da repercussão desses acontecimentos nas casas legislativas e nos tribunais jurisdicionais. Mas vale consignar que a consolidação ocorreu exponencialmente apenas na década de 70.

É verdade que nos países de tradição na common law, conforme adverte Marcelo Gomes Sodré, os primeiros julgados surgiram mais cedo, como foi o caso dos Estados Unidos, em meados de 1920, tendo como assunto a responsabilidade civil da indústria automobilística em relação aos consumidores ${ }^{85}$. A sistematização do assunto ocorreu, contudo, apenas nos anos 70 e muitos dos países desenvolvidos ainda continuam a legislar sobre o assunto, como é o caso da regulamentação do comércio eletrônico, fruto da Revolução das Tecnologias da Informação e Comunicação.

Nos países da América Latina, pelo tardio processo de industrialização que ocorreu somente no início do Século XX, ou seja, muito mais tarde do que na Europa e nos Estados Unidos que vivenciaram esse processo no decorrer dos Séculos XVIII e XIX, a regulamentação deu-se apenas no final do último século, motivada pela Resolução n o 39/248 da Assembleia Geral da Organização das Nações Unidas, de 9 de abril de 1985. Essa resolução traçou diretrizes para a proteção do consumidor, influenciando vários países a discutir e aprovar leis de defesa dos consumidores, evidentemente com exceção de Cuba, socialista desde a década de 1950.

No Brasil, a regulamentação consumerista ocorreu através da aprovação da Lei ${ }^{\circ}$ 8.078, de 11 de setembro de 1990, que instituiu o Código de Defesa do Consumidor, cuja legislação inspirou a lei de proteção ao consumidor da Argentina, reformas no Paraguai e Uruguai e projetos em países europeus ${ }^{86}$. Há que se lembrar que no Ato das Disposições Constitucionais Transitórias já se previa no art. 48 a incumbência do Congresso Nacional de elaborar o Código de Defesa do Consumidor em 180 dias da promulgação da Constituição Federal.

\footnotetext{
${ }^{85}$ SODRÉ, Marcelo Gomes. A construção do Direito do Consumidor: um estudo sobre as origens das leis principiológicas de defesa do consumidor. São Paulo: Atlas, 2009.

${ }^{86}$ NUNES, Rizzato. Curso de Direito do Consumidor. 7. ed. São Paulo: Saraiva, 2012.
} 
O Código de Defesa do Consumidor, na forma prescrita no art. $5^{\circ}$, inciso XXXII, da Constituição Federal, estabeleceu diversos princípios logo em seu art. $4^{\circ}$, incluindo: o reconhecimento da vulnerabilidade do consumidor no mercado de consumo (inciso I); ação governamental no sentido de proteger efetivamente o consumidor (inciso II); educação e informação de fornecedores e consumidores (inciso IV); e o estudo constante das modificações do mercado de consume (inciso VIII); entre outros.

Incluiu-se, ademais, em seu inciso $\mathrm{V}$, “o incentivo à criação pelos fornecedores de meios eficientes de controle de qualidade e segurança de produtos e serviços, assim como de mecanismos alternativos de solução de conflitos de consumo", como política de harmonização da relação de consumo pautada no efetivo reconhecimento da hipossuficiência do consumidor, enquanto sujeito da relação consumerista.

\subsection{Consumidor, fornecedor e relação de consumo}

Ao estabelecer como princípio o reconhecimento da vulnerabilidade do consumidor no mercado de consumo, o Código de Defesa do Consumidor sacramentou essa fragilidade já prescrita no texto constitucional e traçou um corte transversal no sistema normativo, evidenciando a necessidade de proteção dos direitos consumeristas (art. $5^{\circ}$, XXXII).

Antes de examinar as justificativas dessa proteção, é imprescindível compreender quem é o consumidor e o fornecedor como sujeitos da relação de consumo, sem qualquer pretensão de navegar sobre as águas profundas da teoria consumerista. Busca-se tão somente definir o contorno dessas figuras para melhor compreender a vulnerabilidade do consumidor como sujeito da relação de consumo.

Por relação de consumo deve-se entender a relação jurídica estabelecida entre fornecedor, como sujeito ativo, e consumidor, como sujeito passivo, tendo por objeto a oferta de produtos ou serviços adquiridos ou utilizados como bens de consumo. Entende Paulo Valério Dal Pai Moraes que essa relação inicia-se no momento da concepção de um produto 
ou de um serviço, prolongando-se até a mais remota e inesperada consequência atrelada a sua aquisição $^{87}$.

Para Otavio Pinto e Silva, a relação de consumo é um das espécies de relação jurídica inserida pelo Código de Defesa do Consumidor no ordenamento jurídico pátrio, que se traduz como "a relação jurídica que se estabelece entre fornecedores e consumidores, tendo por objeto a oferta de produtos ou serviços no mercado de consumo" ${ }^{\text {" }}$. No entender do jurista, trata-se de uma relação obrigacional regida pela premissa de proteção ao consumidor, tendo como vínculo de atributividade o relacionamento estabelecido entre os atores do mercado de consumo, os quais detém o poder de exigir algo ou de exercer uma pretensão ${ }^{89}$.

Newton de Lucca esclarece que o conceito de consumidor insculpido na Lei $\mathrm{n}^{\circ}$ 8.078/90 é plurívoco e plurívoco análogo, pois comporta quatro possíveis dimensões, sendo uma fundamental (art. $2^{\circ}$ ) e outras três por equiparação (art. $2^{\circ}$, § único; art. 17 e art. 29) ${ }^{90}$.

Quanto ao conceito fundamental, dispõe o caput do art. $2^{\circ}$ do Código de Defesa do Consumidor que "consumidor é toda pessoa física ou jurídica que adquire ou utiliza produto ou serviço como destinatário final”. E, quanto aos conceitos por equiparação, entende-se também por consumidor a coletividade de pessoas, indetermináveis ou não, intervenientes nas relações de consumo (art. $2^{\circ}, \S$ único); as vítimas do acidente de consumo, mesmo não sendo consumidoras direta (art. 17); e as pessoas expostas a práticas comerciais, determináveis ou não (art. 29).

Portanto, se o conceito insculpido no art. $2^{\circ}$ é individual e mais concreto, o artigo 29 traz um conceito difuso, mais abstrato, ao passo que, da perspectiva da potencialidade, refere-se ao consumidor que presumivelmente exista, mesmo que possa não ser determinado ${ }^{91}$.

Partindo do exame do art. $2^{\circ}$, o termo "destinatário final", embora pareça suficiente para se concluir quem é o consumidor, com o emprego da mera interpretação

\footnotetext{
${ }^{87}$ MORAES, Paulo Valério Dal Pai. Código de defesa do consumidor: no contrato, na publicidade, nas demais práticas comerciais. 2. ed. Porto Alegre: Síntese, 2001.

${ }^{88}$ SILVA, Otavio Pinto e. Relações de trabalho e relações de consumo: o futuro da Justiça do Trabalho. Revista do Departamento de Direito do Trabalho e da Seguridade Social, São Paulo, v. 1, n. 1, p. 143-162, jan./jun. 2006. p. 157.

${ }^{89}$ Ibidem.

${ }^{90}$ DE LUCCA, Newton. Teoria geral da relação jurídica de consumo. 2001. 117 f. Tese (Titular) - Faculdade de Direito, Universidade de São Paulo, São Paulo, 2001.

${ }^{91}$ NUNES, Rizzato. Curso de Direito do Consumidor. 7. ed. São Paulo: Saraiva, 2012.
} 
gramatical pode levar a um entendimento equivocado. Em diversas situações pode-se ter a aquisição de produto ou serviço como destinatário final, sem que de fato o adquirente seja consumidor, inexistindo, pois, uma relação de consumo.

Tome-se, como exemplo, um sujeito que se põe a explorar o ramo de panificação e encomende uma panificadora para produção de pães, doces e afins. Não há dúvida de que esse sujeito é destinatário final da panificadora, haja vista que o que irá para os clientes são os pães e não o maquinário. Porém, isso não faz desse sujeito um consumidor, tampouco atrai a aplicação das regras de proteção consumerista em relação ao fornecedor do maquinário. Para que seja uma típica relação de consumo protegida pelo Código de Defesa do Consumidor, o termo "destinatário final" requer um complemento não contido no art. $2^{\circ}$ do mencionado diploma: "bens típicos de consumo"; ou seja, o consumidor é o destinatário final de bens típicos de consumo e não de bens de produção, como é o caso de exemplo apresentado, que deverá ser regido pelas regras do direito comum.

E se para o aparelhamento de sua panificadora esse mesmo sujeito adquirisse um computador para auxiliar nas atividades de caixa, pela lógica acima construída, poder-se-ia concluir, diga-se de passagem equivocadamente, que se trata de um bem de produção, afastando, assim, a aplicação do Código de Defesa do Consumidor, caso o computador apresentasse problemas. O equívoco está em se concluir pelo afastamento da relação consumerista simplesmente pelo uso do computador em atividade de produção, o que levaria ao sepultamento da possibilidade de se reconhecer na maioria dos casos como consumidora qualquer pessoa jurídica, conforme estabelece o próprio art. $2^{\circ}$.

Para que se entenda que, nesse último caso, a panificadora é consumidora, é preciso também considerar que o computador foi ofertado no mercado de consumo para que qualquer pessoa o adquira e dele faça uso como quiser (para uso pessoal ou não), diferentemente do primeiro exemplo, pois a aquisição de uma panificadora não está para o mercado de consumo e não é um bem típico de consumo.

Rizzato Nunes esclarece que o Código de Defesa do Consumidor demonstra uma “clara preocupação com bens típicos de consumo, fabricados em série, levados ao mercado numa rede de distribuição, com ofertas sendo feitas por meio de dezenas de veículos de comunicação, para que alguém num certo momento os adquira"92.

\footnotetext{
${ }^{92}$ NUNES, Rizzato. Curso de Direito do Consumidor. 7. ed. São Paulo: Saraiva, 2012. p. 126.
} 
Portanto, só é consumidor aquele que adquire um produto ou serviço ofertado como um típico bem de consumo, pouco importando o uso que o destinatário fará.

A regra comporta exceções, pois há situações em que será importante examinar se o produto ou serviço será usado ou não na produção de outro, sobretudo quando não se tratar de um bem típico de consumo, embora adquirido com essa finalidade. A título de exemplo, um Boeing 737, utilizado no transporte de carga comercial e de passageiros, portanto, em regra, um bem de produção, pode ser adquirido por um milionário como bem de consumo, mesmo não o sendo em regra essa aeronave ${ }^{93}$. Neste caso, para atrair a incidência das regras da Lei no 8.078/90 em seu benefício, deverá o milionário demonstrar que a existência de uma relação consumerista, ou seja, que a aeronave foi vendida e adquirida como bem de consumo.

Dito isto, pondera Rizzato Nunes que "toda vez que o produto e/ou o serviço puderem ser utilizados como bem de consumo, incide na relação as regras do CDC" ${ }^{94}$, ou seja, "dependendo do tipo de produto ou serviço, aplica-se ou não o Código, independentemente de o produto ou serviço estar sendo usado ou não para a 'produção' e outro"95.

Diante de todas essas elucidações, há que se esclarecer que o consumidor retratado nesta abordagem é aquele que se utiliza dos serviços de telemarketing, cujo contexto é o pano de fundo deste estudo. Procurou-se priorizar esse perfil de consumidor em razão da inegável tensão entre interesses consumeristas e trabalhistas evidenciada no Decreto 6.523/08 e no Anexo II da Norma Regulamentadora $n^{\circ} 17$ (NR 17), aprovado pela Portaria $n^{\circ}$ 9/2007 do Ministério do Trabalho e Emprego, mais a frente abordados.

Quanto ao fornecedor, não economizou o legislador ao defini-lo no caput do art. $3^{\circ}$ da Lei $n^{\circ} 8.078 / 90$ como toda pessoa, seja física ou jurídica, pública ou privada, nacional ou estrangeira, inclusive os entes despersonalizados (massa falida, pessoas jurídicas de fato, etc.), que desenvolvem atividades de produção, montagem, criação, construção, transformação, importação, exportação, distribuição ou comercialização de produtos ou prestação de serviços.

\footnotetext{
${ }^{93}$ NUNES, Rizzato. Curso de Direito do Consumidor. 7. ed. São Paulo: Saraiva, 2012.

${ }^{94}$ Ibidem, p. 128.

${ }^{95}$ Ibidem, p. 126.
} 
Note-se que, a intenção do legislador era não deixar que nenhuma espécie de pessoa jurídica escapasse ao conceito de fornecedor, englobando no gênero (fornecedor) suas mais diversas espécies (fabricante, produtor, importador, construtor, comerciante, etc.). No entanto, bastaria que fosse inserido o termo "toda pessoa jurídica" que já se alcançaria tal propósito.

Em relação à pessoa física como fornecedora, pouco disse a Lei $\mathrm{n}^{\circ}$ 8.078/90, mas sabe-se que diz respeito ao profissional liberal como prestador de serviço, à pessoa física prestadora de serviço não caracterizada como profissional liberal e à pessoa física que não é comerciante de fato, tampouco sociedade de fato, mas exerce uma atividade comercial, de forma não organizada e eventual, com intuito de obter lucro ${ }^{96}$.

Em suma, de uma maneira sucinta, porém abrangente, “o fornecedor é aquele que pratica os seus atos de maneira organizada, tendo por fim uma constante oferta de serviços à coletividade: essa sua 'atividade' é fornecida, mediante remuneração, no mercado de consumo" 97 .

Feitos estes esclarecimentos, se está claro que é o fornecedor quem detém a força de trabalho e o conjunto de mecanismos e habilidades necessária para realizar e controlar as atividades de produção, é também evidente a vulnerabilidade tanto do consumidor como do empregado, pois ambos se submetem a um sujeito que é, ao mesmo tempo e quase sempre, porém, em relações jurídicas distintas, fornecedor e empregador.

Embora se manifestem de forma distinta, essas vulnerabilidades hão de se abalroar e seus reflexos, inevitavelmente, alcançarão o meio ambiente do trabalho, conforme se pretende demonstrar ao longo deste estudo.

\subsection{Vulnerabilidade e hipossuficiência: conceito e principiologia}

Não é verdade que vulnerabilidade e hipossuficiência, institutos caros tanto ao Direito do Trabalho como ao Direito do Consumidor, guardam o mesmo significado, embora sejam evidentemente conexos.

\footnotetext{
${ }^{96}$ NUNES, Rizzato. Curso de Direito do Consumidor. 7. ed. São Paulo: Saraiva, 2012.

${ }^{97}$ SILVA, Otavio Pinto e. Relações de trabalho e relações de consumo: o futuro da Justiça do Trabalho. Revista do Departamento de Direito do Trabalho e da Seguridade Social, São Paulo, v. 1, n. 1, p. 143-162, jan./jun. 2006. p. 159.
} 
De início, vulnerabilidade é a qualidade atribuída a quem é vulnerável que, na definição dos léxicos, é aquele "que se vulnera; diz-se do lado fraco de um assunto ou questão, e do ponto por onde alguém pode ser atacado ou ferido" ${ }^{98}$. Portanto, é o mais suscetível de ser prejudicado, ofendido, danificado, melindrado, magoado ou destruído.

Segundo Paulo Valério Dal Pai Moraes, o conceito de vulnerabilidade denota uma relação e somente se expressa diante da atuação de alguma coisa sobre algo ou sobre alguém, de modo a evidenciar a qualidade daquele que foi ferido, ofendido, prejudicado pela atuação de quem possui alguma potência suficiente para tanto ${ }^{99}$. Assim, o vulnerável só o é em relação a algo ou alguém.

José Geraldo Brito Filomeno esclarece que a vulnerabilidade é um traço universal de um determinado grupo e pressupõe fragilidade (técnica, jurídica e econômica), sendo gênero do qual a hipossuficiência, que é uma determinada vulnerabilidade de certo integrantes daquele grupo (por exemplo, jurídica), é espécie ${ }^{100}$.

Posto isto, importa diferenciar vulnerabilidade e hipossuficiência. Na lição de Cláudio Bonatto, enquanto a vulnerabilidade é um instituto de direito material e geral, a hipossuficiência corresponde a um instituto processual e particularizado, que expressa, por exemplo, uma dificuldade de litigar, seja no tocante às condições de suportar os gastos com a demanda, seja quanto à capacidade de produzir as provas necessárias para demonstrar certos direitos ${ }^{101}$.

Assumindo entendimento semelhante, Antonio Herman de Vasconcellos e Benjamin aborda o assunto na perspectiva do Direito do Consumidor:

A vulnerabilidade é um traço universal de todos os consumidores, ricos ou pobre, educados ou ignorantes, crédulos ou espertos. Já a hipossuficiência é marca pessoal, limitada a alguns - até mesmo a uma coletividade - mas nunca a todos os consumidores.

\footnotetext{
${ }^{98}$ FERREIRA, Aurélio Buarque de Hollanda. Dicionário da Língua Portuguesa. 11. ed. Rio de Janeiro: Editora Civilização Brasileira, 1987. p. 1256.

${ }^{99}$ MORAES, Paulo Valério Dal Pai.Código de defesa do consumidor: no contrato, na publicidade, nas demais práticas comerciais. 2. ed. Porto Alegre: Síntese, 2001.

${ }^{100}$ FILOMENO, José Geraldo Brito. Manual de direitos do consumidor. 10. ed. São Paulo: Atlas, 2010.

101 BONATTO, Cláudio. Questões controvertidas no Código de Defesa do Consumidor: principiologia, conceitos, contratos. 4. ed. Porto Alegre: Livraria do Advogado, 2003.
} 
Judith Martins Costa, recorrendo aos aspectos contextuais jurídicos, assim os diferencia:

Um e outro conceito denotam realidade jurídica distintas, com consequências jurídicas também distintas. Nem todo o consumidor é hipossuficiente. O preenchimento valorativo da hipossuficiência - a qual se pode medir por graus - se há de fazer, nos casos concretos, pelo juiz, com base nas 'regras ordinárias de experiência' e em seu suporte fático encontrase, comumente, elementos de natureza socioeconômica (...). Sua aplicação depende da discricionariedade judicial e a sua consequência jurídica imediata é a da inversão do ônus probandi, no processo civil, para a facilitação da defesa de seus direitos. ${ }^{102}$

Para melhor entender essa síntese, enquanto a vulnerabilidade impulsiona e legitima a existência de um regramento protetivo, a hipossuficiência legitima o tratamento ímpar no interior desse regramento, para nivelar o desequilíbrio da relação jurídica em um dado contexto.

É o caso da inversão do ônus da prova mencionado no recorte doutrinário anteriormente exposto, que se aplica tanto ao processo civil, especialmente no âmbito do Direito do Consumidor, como ao processo do trabalho. Levando-se em consideração esses dois sistemas, os vulneráveis seriam os consumidores e empregados, enquanto os hipossuficientes seriam alguns consumidores e empregados que, na condição de sujeitos processuais, encontrassem dificuldades para se desincumbir do ônus probatório na comprovação de eventuais direitos.

Nesse prisma, fica ainda mais claro que tanto a vulnerabilidade como a hipossuficiência expressam o sentido de relação já apontado por Paulo Valério Dal Pai Moraes, pois o vulnerável só o é diante de um contexto, da atuação de algo ou de alguém que evidencia sua fragilidade. Quanto ao hipossuficiente, ocorre o mesmo, pois a hipossuficiência apenas se aperfeiçoa através do exame da condição do sujeito frente ao caso concreto e a parte adversária.

Ao revelar as diversas dimensões da vulnerabilidade, Paulo Valério Dal Pai Moraes ${ }^{103}$ chega a apontar seis espécies: vulnerabilidade técnica, vulnerabilidade jurídica,

\footnotetext{
${ }^{102}$ COSTA, Judith Martins. A 'Guerra' do Vestibular e a Distinção entre Publicidade Enganosa e Clandestina. Revista Direito do Consumidor, São Paulo, v. 6, abr./jun., p. 219-231, 1993. p. 222.

${ }^{103}$ MORAES, Paulo Valério Dal Pai.Código de defesa do consumidor: no contrato, na publicidade, nas demais práticas comerciais. 2. ed. Porto Alegre: Síntese, 2001.
} 
vulnerabilidade política ou legislativa, vulnerabilidade biológica ou psíquica, vulnerabilidade econômica e social e vulnerabilidade ambiental.

Para o jurista, a vulnerabilidade técnica configura-se principalmente pela insuficiência ou incorreção na prestação de informações ou, até mesmo, pelo excesso de informações desnecessárias, impedindo que o consumidor se atente para aquelas que de fato interessam. Essa espécie de vulnerabilidade é explicada pelo fato de que consumidor não detém o conhecimento sobre todo o processo de produção ou de prestação de serviços, dependendo do fornecedor para alcançar essas informações ${ }^{104}$.

A vulnerabilidade jurídica diz respeito às dificuldades encontradas pelo consumidor para defender seus direitos, tanto na esfera administrativa como na judicial, que às vezes não sabem nem mesmo a qual órgão se dirigir para buscar a satisfação de um direito violado. Paulo Valério Dal Pai Moraes alerta que o consumidor está diante muitas vezes de uma necessidade premente, enquanto o fornecedor, na condição de litigante potencial ou habitual, tem a seu favor a experiência acumulada e a preparação para o que há por vir; não tem a menor pressa, interessando-lhe mais a demora do que o pronto encerramento da demanda ${ }^{105}$. Esta tática também é seguida por muitas empresas no âmbito trabalhista.

Por vulnerabilidade política ou legislativa, entende-se a fragilidade do consumidor no cenário brasileiro, tanto em relação à escassez de associações ou órgãos dispostos a conter mecanismos prejudiciais aos interesses consumeristas como a construção de leis sem a participação efetiva dos consumidores, mas tão somente pela maioria detentora do poder econômico e político, que possuem maiores condições de criar o direito e impingi-lo contra os demais. Essas regras, portanto, não corresponderiam à vontade da maioria. É o caso da edição e reedição desenfreada de medidas provisórias, que acabam por se converter em leis ${ }^{106}$.

Por sua vez, a vulnerabilidade biológica ou psíquica diz respeito à fragilidade do consumidor, que decorre da simples natureza humana e está à disposição de interessados na sua estimulação. Esses interessados, a partir do estudo do complexo nervoso, empregam todas as técnicas para "criar" necessidades, desejos e manipular vontades, buscando, perversamente,

\footnotetext{
${ }^{104}$ MORAES, Paulo Valério Dal Pai.Código de defesa do consumidor: no contrato, na publicidade, nas demais práticas comerciais. 2. ed. Porto Alegre: Síntese, 2001.

${ }^{105}$ Ibidem.

${ }^{106}$ Ibidem.
} 
incrementar o consumo de produtos e serviços, muitas vezes supérfluos, sem que o consumidor se atente que está sendo envolvido.

Paulo Valério Dal Pai Moraes apresenta como exemplo as mensagem subliminares em publicidades praticadas em novelas, filmes e seriados e seus efeitos no interior neurológico, citando como recortes concretos a incitação ao crédito, o consumo de serviços e produtos não essenciais e a obsolescência programada ${ }^{107}$.

A vulnerabilidade econômica social configura-se pelo desequilíbrio de forças entre os consumidores e os agentes econômicos, que possuem maiores condições de submeter aqueles às suas vontades através de mecanismos técnicos sofisticados garantidos pelo poder econômico. É a submissão do consumidor “às imposições econômicas e políticas dos mais fortes, sofrendo diretamente os reflexos de qualquer medida que venha a interferir na circulação da moeda e, em especial, do crédito" ${ }^{\text {"108. }}$.

Alguns elementos acentuam ainda mais essa espécie de vulnerabilidade como: a eliminação da concorrência; as leis rígidas a respeito de patentes; a dificuldades de pagar os custos de locomoção nas grandes cidades, obrigando a aquisição nos locais mais acessíveis, porém não necessariamente mais baratos ou com qualidade de produtos ou serviços; a dificuldade de obtenção de saúde e de educação, que favoreceria a formação cidadã e a ascensão social $^{109}$.

E, por fim, a vulnerabilidade ambiental "decorre da própria tradição consumerista de considerar o ato de consumo como ação restrita ao objetivo imediato de satisfação de alguma necessidade momentânea, sem considerar as implicações, os efeitos deste ato como um todo" ${ }^{110}$. Esta espécie de vulnerabilidade considera a intersecção entre proteção da saúde e da segurança do consumidor e proteção ambiental.

Assevera Paulo Valério Dal Pai Moraes que a produção, o transporte de bens, o uso de produtos em geral, em suma, a filosofia consumista tem causado graves danos ao meio ambiente e, por consequência, ao consumidor, chancelando a sobreposição da produção econômica a valores maiores como a saúde, a segurança, a vida, como direitos básicos

\footnotetext{
${ }^{107}$ MORAES, Paulo Valério Dal Pai.Código de defesa do consumidor: no contrato, na publicidade, nas demais práticas comerciais. 2. ed. Porto Alegre: Síntese, 2001.

${ }^{108}$ Ibidem, p. 161.

${ }^{109}$ Ibidem.

${ }^{110}$ Ibidem.
} 
previsto no Código de Defesa do Consumidor (art. $4^{\mathrm{o}}$, III) ${ }^{111}$. Pouco sabe o consumidor do destino das embalagens e dos resíduos da produção e seu potencial ofensivo ao meio ambiente, que constitui seu habitat. Em geral, a informação sobre os impactos de determinados produtos na saúde e no ambiente também é precária.

Por isso, a vulnerabilidade ambiental decorre diretamente das imposições mercadológicas, responsáveis por levar à sociedade produtos e serviços apresentados, em princípio, como benéficos e vantajosos, mas que, em verdade, seu potencial danoso é infinitamente superior ${ }^{112}$.

Essa visão multidimensional legitima a elevação da vulnerabilidade do consumidor ao patamar principiológico, tal como ocorreu no Direito do Trabalho em relação ao trabalhador com a cristalização do Princípio da Proteção ao Trabalhador, que se subdivide em outros três (Princípio da norma mais favorável, Princípio da condição mais benéfica e Princípio in dúbio pro misero).

Segundo Vólia Bomfim Cassar, o Princípio da Proteção caracteriza-se "pela intensa intervenção estatal brasileira nas relações entre empregado e empregador, o que limita, em muito, a autonomia da vontade das partes", pois "o Estado legisla e impõe regras mínimas que devem ser observadas pelos agentes sociais" $" 113$.

De acordo com Maurício Godinho Delgado ${ }^{114}$, este princípio - por ele também chamado de Princípio Tutelar - informa que o Direito do Trabalho sustenta em sua estrutura uma teia de proteção ao trabalhador como parte hipossuficiente da relação de trabalho, buscando atenuar, no plano jurídico, o desequilíbrio inerente a realidade do contrato de trabalho.

Assegura Américo Plá Rodriguez que este princípio é a própria razão de ser do Direito do Trabalho, cujo regramento surgiu para frear as formas de exploração mais perversas e abusivas praticadas na história do trabalho com o aval da liberdade de contrato entre pessoas com poder e capacidade econômica desiguais ${ }^{115}$. E é justamente essa

\footnotetext{
${ }^{111}$ MORAES, Paulo Valério Dal Pai.Código de defesa do consumidor: no contrato, na publicidade, nas demais práticas comerciais. 2. ed. Porto Alegre: Síntese, 2001.

112 Ibidem.

113 CASSAR, Vólia Bomfim. Direito do Trabalho. 5. ed. Niterói: Impetus, 2011. p. 185.

114 DELGADO, Maurício Godinho. Curso de Direito do Trabalho. 8. ed. São Paulo: LTr, 2009.

${ }^{115}$ PLÁ RODRIGUEZ, Américo. Princípios de Direito do Trabalho. Tradução Wagner D. Giglio. 3. ed. São Paulo: LTr, 2000.
} 
subordinação que embasa o Princípio Protetor, de acordo com Homero Batista Mateus da Silva ${ }^{116}$.

De igual forma, o Princípio da Vulnerabilidade do Consumidor, consubstanciado no art. $4^{\circ}$, inciso I, da Lei $n^{\circ} 8.078 / 90$, fez um corte transversal no sistema positivado brasileiro, de modo a reconhecer a fragilidade do consumidor na relação de consumo e concretizar o Princípio da Isonomia, ao qual é diretamente vinculado. Dessa forma, apregoou o tratamento desigual pela lei, para que se atingisse a igualdade real e se cumprisse o dogma constitucional da isonomia (art. $5^{\circ}$, caput), na medida em que devem os desiguais serem tratados desigualmente na medida exata de sua desigualdades ${ }^{117}$. Essa desigualdade emana do fato de que é o fornecedor quem detém o controle do mercado de consumo e escolhe o que, como, quando e para quem produzir e o quanto vai lucrar.

Mesmo antes da concepção do Código de Defesa do Consumidor, a Constituição Federal de 1988 já havia previsto a defesa do consumidor no plano da política constitucional (art. $5^{\circ}$, inciso XXXII), incluindo-a no rol de direitos e garantias fundamentais (art. 60, $\S 4^{\circ}$, inciso IV). O texto constitucional já descortinada a necessidade de nivelamento do desequilíbrio entre os sujeitos da relação consumerista, visando resguardar a incolumidade do consumidor em todas as suas dimensões.

De acordo com José Geraldo Brito Filomeno, o movimento consumerista se desenvolveu nos Estados Unidos ao mesmo tempo em que os movimentos sindicalistas reclamavam por melhores condições de trabalho. Somente com a criação da Consumers League (1891), em Nova York, cindiu-se o movimento trabalhista-consumerista, cada qual seguindo caminhos próprios, embora com propostas bem parecidas quanto aos instrumentos de tutela de seus interesses ${ }^{118}$.

Daí, não se duvida que o Direito do Consumidor tenha encontrado inspiração no Direito do Trabalho, especialmente no Princípio da Proteção, para a construção do Princípio da Vulnerabilidade do Consumidor.

\footnotetext{
${ }^{116}$ SILVA, Homero Batista Mateus da. Curso de Direito do Trabalho aplicado: parte geral. v. 1. Rio de Janeiro: Elsevier, 2009. p. 150.

117 NERY JUNIOR, Nelson. Princípios gerais do Código Brasileiro do Consumidor. Revista Direito do Consumidor, Editora RT, São Paulo, v. 3, set./dez. 1992.

${ }^{118}$ FILOMENO, José Geraldo Brito. Da política nacional das relações de consumo. In BENJAMIM, Antonio Herman V. et al. Código brasileiro de defesa do consumidor: comentado pelos autores do anteprojeto. Rio de Janeiro: Forense Universitária, 1998.
} 
Diz-se isso, pois o reconhecimento da vulnerabilidade do trabalhador precedeu a do consumidor, não havendo dúvidas de que o regramento trabalhista, com sua teia de proteção, surgiu muito mais cedo do que as primeiras regras consumeristas, até porque o movimento operário tem raízes no século XVIII e o movimento consumerista no século XX. Da mesma forma ocorreu no Brasil, cujo avanço social e jurídico sempre foi mais tardio em relação aos países desenvolvidos, que vivenciaram os movimentos sociais muito mais cedo, conforme já demonstrado na abordagem histórico-evolutiva antes apresentada. Enquanto a Consolidação das Leis do Trabalho é de 1943, o Código de Defesa do Consumidor é de 1990.

Por fim, importa dizer que, guardadas as devidas peculiaridades, tanto a relação de trabalho como a relação de consumo se assentam cada qual em seu "princípio protetor", por constituírem uma relação jurídica tão assimétrica, que já não mais se duvida que uma das partes sempre estará em desvantagem para negociar, exigir e cobrar, cabendo à ciência jurídica instituir, na medida do possível, formas de reequilíbrio no plano material e processual $^{119}$.

\subsection{A harmonização da relação de consumo: finalidade e mecanismos de viabilização}

O Código de Defesa do Consumidor instituiu, como princípio da Política Nacional das Relações de Consumo, a harmonização dos interesses dos sujeitos das relações de consumo, tendo em vista o equilíbrio da proteção do consumidor com a necessidade de desenvolvimento econômico e tecnológico (art. $4^{\circ}$, inciso III). Com base na boa-fé e no equilíbrio das relações entre consumidores e fornecedores, o intuito é viabilizar os princípios nos quais se funda a ordem econômica, nos termos do art. 170 da Constituição Federal, dentre eles, a livre concorrência (art. 170, inciso IV), a defesa do consumidor (art. 170, inciso V), a defesa do meio ambiente (art. 170, inciso VI) e a busca do pleno emprego (art. 170, inciso VIII).

Portanto, consoante ao que determina a Política Nacional das Relações de Consumo, o mandamento principiológico contido no art. $4^{\circ}$, inciso III, do Código de Defesa do Consumidor, é harmonizar, equacionar, equilibrar as relações de consumo. É garantir o respeito à dignidade, saúde, segurança, qualidade de vida e a proteção dos interesses

\footnotetext{
${ }^{119}$ SILVA, Homero Batista Mateus da. Curso de Direito do Trabalho aplicado: parte geral. v. 1. Rio de Janeiro: Elsevier, 2009.
} 
econômicos dos consumidores, sem que isso inviabilize o desenvolvimento econômico e tecnológico. É, em suma, a ideia de equilíbrio e não de sobreposição.

Ainda convém elucidar quais são os mecanismos de harmonização da relação de consumo. De início, é preciso apontar que o Código de Defesa do Consumidor não se pôs a construir um rol de instrumentos ou medidas para atender a essa finalidade. E nem poderia, sob pena de engessar as possibilidades. Contudo, deixou algumas pistas, como é o caso do art. $4^{\mathrm{o}}$, inciso $\mathrm{V}$.

Aponta José Geraldo Brito Filomeno três instrumentos a serem utilizados para a harmonização das relações de consumo: o Serviço de Atendimento ao Consumidor, também conhecido como marketing de defesa do consumidor, telemarketing ou teleatendimento; o recall; e a convenção coletiva de consumo ${ }^{120}$.

O recall é previsto no art. 10 do Código de Defesa do Consumidor e visa à retirada do mercado, a reparação do defeito ou a recompra de produtos ou serviços defeituosos a título gratuito, portanto, às expensas do fornecedor. Tanto a informação do recall como os riscos aos quais os consumidores forem expostos em decorrência da aquisição ou utilização do produto ou serviço devem ser amplamente divulgados, também às expensas do fornecedor, devendo a União, os Estados, o Distrito Federal e os Municípios, sempre que tiverem conhecimento de periculosidade de produtos ou serviços à saúde dos consumidores, informá-los a respeito.

A convenção coletiva de consumo, prevista no art. 107 do Código de Defesa do Consumidor, é um instrumento para solução de conflitos coletivos em que os sujeitos da relação de consumo, por meio de entidades representativas, instituem condições que servirão como parâmetro para a celebração e execução de contratos individuais. José Geraldo Brito Filomeno a define como o pacto firmado entre entidades civis de consumidores e associações de fornecedores ou sindicatos de categorias ou, ainda, entre órgãos governamentais e fornecedores $^{121}$.

Explica Homero Batista Mateus da Silva que a convenção coletiva de consumo é um instrumento propício para a manutenção de um canal estreito de comunicação entre consumidores e associações representativas, visando à prevenção e à resolução de conflitos. A

\footnotetext{
${ }^{120}$ FILOMENO, José Geraldo Brito. Manual de direitos do consumidor. 10. ed. São Paulo: Atlas, 2010.

${ }^{121}$ Ibidem.
} 
título de ilustração, aponta que foi por meio desse instrumento que empresas do transporte aéreo solucionaram problemas de excesso de reservas nos voos (overbooking) e supermercados franceses passaram a divulgar os preços de produtos por valor do peso/medida (valor do grama ou do litro) ou do pacote, para facilitar a comparação dos preços praticados pelos fabricantes e evitar equívocos e prejuízos em caso de embalagens de tamanhos diferentes ${ }^{122}$.

A convenção coletiva de consumo deve ser reduzida a termo e, posteriormente, registrada em cartório de registro de títulos e documentos, obrigando todos os filiados às entidades signatárias, mesmo que, após o registro, delas se desliguem. Quanto ao objeto, é vedada a instituição de cláusulas menos favoráveis ao consumidor, bem como contrárias à Lei $n^{\circ}$ 8.078/90. É também um instrumento hábil para dispor parâmetros para reclamação e composição de conflitos de consumo ${ }^{123}$.

Leonardo de Medeiros Garcia até mesmo faz um recorte comparativo com as convenções coletivas de trabalho previstas pela Consolidação das Leis do Trabalho e que, celebradas pelos sindicatos representativos das categorias, assumem eficácia normativa válida para uma determinada coletividade ${ }^{124}$.

O telemarketing, que se enquadra como um dos mecanismos alternativos de solução de conflitos de consumo previstos no art. $4^{\circ}$, inciso $\mathrm{V}$, do Código de Defesa do Consumidor, é talvez o instrumento de harmonização da relação consumerista que esteja mais a serviço do consumidor. Isto porque, independe de motivação coletiva - como é o caso do recall e da convenção coletiva de consumo - e, além da facilidade do acesso remoto por meio de contato telefônico, geralmente está a disposição do usuário para toda e qualquer reclamação, dúvida ou sugestão, durante 24 horas, todos os dias da semana. Certamente, é por este motivo que a atividade expandiu-se surpreendentemente nos últimos anos e gerou milhares de empregos no país, despertando a atenção de consumidores, empresários, trabalhadores, sindicatos e até mesmo do Estado.

Maiores elucidações sobre o telemarketing e sua repercussão econômica e social foram reservadas ao Capítulo 4 deste estudo.

\footnotetext{
${ }^{122}$ SILVA, Homero Batista Mateus da. Curso de Direito do Trabalho aplicado: direito coletivo do trabalho. v. 7. Rio de Janeiro: Elsevier, 2010.

${ }^{123}$ GARCIA, Leonardo de Medeiros. Direito do consumidor: código comentado, jurisprudência, doutrina. Decreto nº 2.181/1997. 8. 8d. Niterói: Impetus, 2012.

${ }^{124}$ Ibidem.
} 
Convém esclarecer que, a despeito de não constar no rol apresentado anteriormente, algumas leis tem se prestado à finalidade de equilibrar a relação entre fornecedores e consumidores.

À guisa de exemplo, alguns estados (São Paulo, Rio de Janeiro, Rio Grande do Sul, Minas Gerais, Paraná, etc.) e municípios brasileiros instituíram a "lei contra demora nas filas", impondo tempo máximo para atendimento dos consumidores de serviços bancários, freando a sanha capitalista empresarial destituída de qualquer preocupação com a qualidade da prestação.

Outro exemplo é o Decreto $\mathrm{n}^{\circ}$ 6.523/08, que fixou normas gerais para o Serviço de Atendimento ao Consumidor (SAC) por telefone, instituindo em seu art. $1^{\circ}$ o dever de observância dos direitos básicos para a obtenção pelos consumidores de informações adequadas e claras sobre os serviços prestados e a proteção contra práticas abusivas ou ilegais.

Não há dúvidas de que esses dispositivos normativos estão alicerçados no art. 20, $\S 2^{\circ}$, do Código de Defesa do Consumidor, que preceitua serem "impróprios os serviços que se mostrem inadequados para os fins que razoavelmente deles se esperam, bem como daqueles que não atendam as normas regulamentares de prestabilidade".

Contudo, não se pode ser ingênuo ao ponto de pensar que essas medidas não impactaram no mundo do trabalho, haja vista que Direito é sistema, os contextos ambientais são interdependentes, o fornecedor é, ao mesmo tempo, fornecedor e empregador, e o coletivo social é unitário. Assim, as relações de consumo e as relações de trabalho ocorrem num mesmo plano social, interagindo e influenciando-se mutuamente. É o que se pretende demonstrar no próximo subcapítulo, que retrata os impactos da harmonização da relação de consumo no mundo do trabalho, bem como no Capítulo 3 , dedicado ao tema meio ambiente do trabalho.

\subsection{A harmonização da relação de consumo e seus impactos no mundo do trabalho}

Os diversos modelos já examinados de reorganização do sistema produtivo, sempre a serviço dos interesses econômicos, jamais deixaram de produzir impactos no mundo do trabalho, cujos estilhaços foram além da circunscrição do locus laboral. A busca 
desenfreada pela acumulação do capital, sustentada pela expansão da produtividade desonerada para fomentar o consumo, comprometeu as condições de trabalho, repercutindo, inclusive, na saúde do trabalhador.

Há ainda que se considerar o contexto atual. A abertura do mercado, decorrente do processo de globalização da economia, intensificou a oferta e o consumo. Com a supressão das barreiras entre fornecedores e consumidores em todo o contexto global, o mercado tornou-se mais competitivo, devido à facilidade de acesso aos consumidores que, em virtude do benefício da concorrência, tornaram-se mais exigentes. Portanto, mais do que angariar uma clientela, tornou-se imprescindível fidelizá-la.

É verdade que, em um primeiro momento, como sempre ocorreu na história do trabalho, os interesses econômicos prevaleceram aos interesses sociais. Contudo, cedo ou tarde, tornou-se essencial a promoção de direitos, da prosperidade, da saúde, da segurança e do bem-estar dos trabalhadores, ainda que progressivamente e a curtos passos, para a própria sobrevivência e desenvolvimento dos objetivos capitalistas.

Em uma abordagem mais contemporânea, foi o que ocorreu na integração comunitária europeia, pois a previsão embrionária de matérias sociais nos Tratados Constitutivos, como o desenvolvimento do emprego e a melhoria das condições de trabalho, embora não tratadas como prioridade, serviram mais tarde para o desenvolvimento do Direito Social Comunitário, que garantiu a viabilidade e a sobrevivência da proposta de integração dos Estados europeus, possibilitando o que hoje se conhece por União Europeia ${ }^{125}$.

A viabilidade dos interesses econômicos no plano da integração comunitária europeia não cuidou somente de instituir, paulatinamente, patamares mínimos em matéria social no campo do direito do trabalho, mas também para as relações de consumo, prevendo a promoção dos direitos, da prosperidade e do bem-estar dos consumidores, como valores fundamentais da União Europeia.

O raiar de uma massa de milhões de consumidores com a integração de mercado e a supressão de fronteiras, assegurou-lhes uma proteção adicional, tal como ocorreu no Direito Comunitário do Trabalho, através da previsão de um nível mínimo de garantias, ressalvando aos Estados-Membros a incumbência de disciplinar os pormenores e as formas de efetivação.

\footnotetext{
${ }^{125}$ BELTRAN, Ari Possidonio. Os impactos da integração econômica no direito do trabalho: globalização e direitos sociais. São Paulo: LTr, 1998. p. 21.
} 
Como se extrai da experiência comunitária europeia, a prosperidade da economia é intrinsecamente relacionada à previsão e manutenção de direitos sociais suficientes para garantir a sustentabilidade dos interesses econômicos. Por isso, evidente a necessidade de harmonização desses interesses com outras dimensões, mormente sociais, situadas no campo da dignidade humana, como por exemplo, nas relações de trabalho e de consumo que, por sua vez, não devem se abalroar.

Não bastasse essa colisão entre matérias econômicas e sociais, o conflito entre interesses econômicos (decorrentes do modelo capitalista empresarial e da política de harmonização da relação de consumo) e interesses sociais (como a garantia à dignidade no trabalho), tem se apresentado e contribuído para a precarização das condições laborais, sobretudo por influenciarem na organização e no equilíbrio do meio ambiente do trabalho.

A instituição de políticas de harmonização da relação de consumo sem qualquer coordenação com o estabelecimento e manutenção de garantias sociais de melhores condições de trabalho, tornou-se mais um trunfo do capital na velha quizila com o trabalho.

Se consumidor é o elo mais fraco da economia, não podendo nenhuma corrente ser mais forte do que seu elo mais fraco ${ }^{126}$, o mesmo ocorre com o empregado, que é o sujeito mais vulnerável da relação de emprego. Se por um lado a política de harmonização da relação de consumo tutela a satisfação das necessidades básicas dos consumidores, como sua dignidade, saúde, segurança, interesses econômicos e a melhoria de sua qualidade de vida, por outro lado, esses mesmos valores também são (ou devem ser) objeto de tutela da legislação e das políticas públicas voltadas para a saúde e segurança no trabalho. Se o consumidor não dispõe de controle sobre os bens de produção, devendo-se se submeter àqueles que o detém $^{127}$, igualmente ocorre com o trabalhador, subordinado ao poder diretivo do empregador, a quem cabe a organização, a disciplina e o controle da atividade.

Nessa perspectiva, empregados e consumidores se assemelham enquanto sujeitos vulneráveis nas relações em que se encontram, evidenciando uma dupla existência de vulnerabilidade, cada qual sob diferentes quadrantes, porém, em alguns casos, sujeitas ao conflito, diante da ausência de harmonização entre as políticas consumeristas e as políticas garantidoras da dignidade no trabalho.

\footnotetext{
${ }^{126}$ BELTRAN, Ari Possidonio. Os impactos da integração econômica no direito do trabalho: globalização e direitos sociais. São Paulo: LTr, 1998.

${ }^{127}$ FILOMENO, José Geraldo Brito. Manual de direitos do consumidor. 10. ed. São Paulo: Atlas, 2010.
} 
É o que se extrai do exame dirigido através do método de casos proposto, que será melhor abordado no Capítulo 4 deste estudo, quando se aponta que a política de harmonização da relação de consumo no setor de telemarketing, descoordenada com as políticas de melhoria das condições laborais, influenciou diretamente o meio ambiente do trabalho, impactando na saúde dos trabalhadores do setor.

No entanto, antes de examinar esses impactos, cuja abordagem pressupõe a interrelação pessoa-ambiente e uma visão sistêmica da interdependência entre contextos ambientais, faz-se necessário primeiro compreender a complexidade do meio ambiente do trabalho e como ele dialoga e negocia com o ser humano, no caso, o trabalhador. Por isso, o Capítulo a seguir se dedica a analisar o conceito jurídico de meio ambiente do trabalho, propondo um novo olhar, sob uma perspectiva interdisciplinar entre Direito do Trabalho e Psicologia Ambiental. 


\section{MEIO AMBIENTE DO TRABALHO E SAÚDE DO TRABALHADOR}

\subsection{A construção do conceito jurídico de meio ambiente do trabalho}

Por algum tempo, a noção de meio ambiente do trabalho focalizava predominantemente os aspectos físicos ambientais e desconsiderava a sinergia entre esse meio e outros contextos correlatos, aproximando-se mais do conceito de estabelecimento empresarial contido no artigo 1.142 do Código Civil do que de meio ambiente.

Pouco se fazia menção aos aspectos psicológicos e comportamentais dos trabalhadores que, na perspectiva construída neste estudo, também integram o meio ambiente do trabalho e sustentam a dinâmica da inter-relação pessoa-ambiente. Também pouco se falava na interdependência entre o meio ambiente do trabalho e outros contextos ambientais que também integram o meio ambiente ao qual se refere o artigo 225 da Constituição da República Federativa do Brasil de 1988.

Recorda José Antônio Ribeiro de Oliveira Silva que, embora a preocupação com o meio ambiente de trabalho seja antiga, sendo possível encontrar vestígios ainda nos primeiros passos da legislação trabalhista do século XIX, ainda não havia a compreensão completa e genérica que hoje se tem sobre meio ambiente geral e do trabalho, alcançada apenas na década de $70^{128}$.

Não é raro encontrar noções sobre meio ambiente do trabalho que compreendam somente as edificações do estabelecimento, instrumentos, maquinários, condições de salubridade e periculosidade, armazenagem e manuseio de materiais, jornada de trabalho, intervalos, iluminação, conforto térmico, instalações elétricas e tecnológicas, entre outros elementos.

Tome-se, como exemplo, a concepção de Amauri Mascaro Nascimento:

Meio ambiente do trabalho é, exatamente, o complexo máquina-trabalho; as edificações do estabelecimento, equipamentos de proteção individual,

\footnotetext{
${ }^{128}$ SILVA, José Antônio Ribeiro de Oliveira. A saúde do trabalhador como um direito humano: conteúdo essencial da dignidade humana. São Paulo: LTr, 2008.
} 
iluminação, conforto térmico, instalações elétricas, condições de salubridade ou insalubridade, de periculosidade ou não, meios de prevenção á fadiga, outras medidas de proteção ao trabalhador, jornadas de trabalho e horas extras, intervalos, descansos, férias, movimentação, armazenagem e manuseio de materiais que formam o conjunto de condições de trabalho, etc. $^{129}$

Na mesma esteira, Mônica Maria Lauzid de Morais, ao conceituar meio ambiente do trabalho, restringe o alcance desse instituto jurídico apenas à circunscrição espacial da prestação laboral e seus aspectos físicos:

Meio ambiente do trabalho é o local onde o homem realiza a prestação objeto da relação jurídico-trabalhista, desenvolvendo atividade profissional em favor de uma atividade econômica. Ao conjunto do espaço físico e as condições existentes no local de trabalho (ferramenta de trabalho, máquinas, equipamentos de proteção individual, temperatura, elementos químicos, etc.) nas quais se desenvolve a prestação laboral denominamos meio ambiente do trabalho. ${ }^{130}$

Sidnei Machado define meio ambiente do trabalho como o "conjunto de condições internas do local de trabalho e sua relação com a saúde dos trabalhadores" ${ }^{131}$, considerando também apenas o espaço onde ocorre a prestação laboral. Antonio Silveira Ribeiro dos Santos amplia o alcance desse contexto ambiental, apoiando-se no artigo $3^{\circ}$, inciso $\mathrm{I}$, da Lei $\mathrm{n}^{\circ}$ $6.938 / 81^{132}$, ao considerar fatores físicos e outros não especificados, definindo-o como "o conjunto de fatores físicos, climáticos ou qualquer outro que interligados, ou não, estão presentes e envolvem o local de trabalho da pessoa" ${ }^{133}$.

Nota-se, portanto, através do exame das noções apresentadas, que pouco se considerava a interdependência do meio ambiente do trabalho com outros contextos e aspectos ambientais que com ele se relacionam, produzindo um feedback recíproco e dinâmico, tendente a influenciar o seu equilíbrio.

\footnotetext{
${ }^{129}$ NASCIMENTO, Amauri Mascaro. A defesa processual do meio ambiente do trabalho. Revista LTr, São Paulo, v. 63, n. 5, 1999. p. 584.

${ }^{130}$ MORAIS, Mônica Maria Lauzid de. O direito à saúde e segurança no meio ambiente de trabalho. São Paulo: LTr, 2002. p. 25.

${ }^{131}$ MACHADO, Sidnei. O direito à proteção ao meio ambiente do trabalho no Brasil. São Paulo: LTr, 2001, p. 66-67.

${ }^{132}$ Art. $3^{\circ}(\ldots)$ I - (...) conjunto de condições, leis, influências e interações de ordem física, química e biológica, que permite, abriga e rege a vida em todas as suas formas.

${ }^{133}$ SANTOS, Antonio Silveira Ribeiro dos. Meio ambiente do trabalho: considerações. Teresina: Jus Navegandi, set. 2000. Disponível em: <jus2.uol.com.br/doutrina/texto.asp?id=1202>. Acesso em: 29 jun. 2011.
} 
Houve ainda quem não considerasse parte do meio ambiente do trabalho a pessoa humana, embora jamais tivessem conseguido defini-lo sem mencionar o organismo vivo e dinâmico que integra esse meio: o próprio trabalhador. É o caso da seguinte definição apresentada por um participante deste estudo:

Entendo como o local onde as pessoas exercem suas atividades, envolvendo as instalações físicas do local, onde devem oferecer um ambiente saudável para a prestação do serviço. (Participante: RH3).

Outros participantes, embora não mencionassem pontualmente o trabalhador ao definir meio ambiente do trabalho, integraram à noção fatores pessoais (psicológicos e comportamentais - relações interpessoais, conhecimento, aprendizagem, etc.), conforme se observa nos seguintes recortes:

Meio ambiente do trabalho é o meio em que as pessoas interagem para realizar suas atividades. Envolve os fatores físicos e psicológicos, desde o material de trabalho, a relação com os colegas, até o reconhecimento profissional. (Participante: RH1).

Meio ambiente do trabalho é tudo aquilo que afeta direta ou indiretamente sua atividade, ou seja, mobiliário, todo material disposto para desenvolvimento da atividade, relação interpessoal, tanto com público interno quanto público externo. (Participante: RH2).

O lugar onde passamos maior parte de nosso tempo, meio de relacionamentos, aprendizagem, conhecimento e avaliação profissional e pessoal que influencia muito na formação de profissionais. (Participante: RH4).

O meio ambiente do trabalho pra mim é... uma espécie de meio ambiente como um todo, ou seja, qualquer interação de elementos e aí não envolve apenas o aspecto físico, mas também a estrutura dinâmica e humana desse ambiente, de forma que o ambiente do trabalho seria esse conjunto entre o espaço físico e condições relacionadas a estrutura de relacionamento humano em que labor se desenvolve. (Participante: MT3).

É um conceito bastante amplo, bastante aberto... Mas eu penso muito em equilíbrio. Quando me vem à mente, a melhor palavra, minha melhor definição é equilíbrio. $\mathrm{O}$ equilíbrio envolve, evidentemente, os elementos químicos, físicos, mas também envolve a harmonia do relacionamento. Então um meio ambiente do trabalho pode estar negligenciado, desgastado, sem que haja um derramamento de mercúrio ou uma poluição sonora no local, bastando apenas que haja um chefe neurótico, por exemplo, ou que haja uma gestão pelo temor... ou a gestão pela pressão. Então, a partir dessa premissa do equilíbrio, meio ambiente se torna sinônimo de harmonia (Participante: MT1). 
Entendo que é o espaço que abarca a estrutura física e também os relacionamentos de trabalho; não somente os aspectos físicos. (Participante: MT2).

Paulatinamente, a noção de meio ambiente do trabalho recebeu novos contornos que permitiram melhor compreender seus impactos na saúde do trabalhador, bem como a influência de contextos mais amplos (sistemas econômico, político, etc.) na organização e nas condições laborais. Esse esforço, sobretudo da área da saúde e das ciências ecológicas, permitiram também repensar estratégias para se alcançar um meio ambiente do trabalho equilibrado, condizente com o dever de proporcionar dignidade no trabalho a todos, sem qualquer distinção.

Concepções mais abrangentes acerca do assunto, porém ainda incompletas por não compreenderem o trabalhador como parte do ambiente, cavaram espaço no celeiro doutrinário, contemplando os aspectos imateriais do meio e sua inter-relação com ambientes correlatos, espraiando-se para além do espaço interno onde ocorre a prestação laboral. Nesse sentido, aponta Cláudio Mascarenhas Brandão que o meio ambiente do trabalho "não se restringe ao espaço interno da fábrica ou da empresa e alcança, por isso mesmo, o próprio local de morada e o ambiente urbano" ${ }^{134}$, devendo se considerar:

o conjunto de todos os fatores que, direta ou indiretamente, se relacionam com a execução da atividade do empregado, envolvendo os elementos materiais (local de trabalho em sentido amplo, máquinas, móveis, utensílio e ferramentas) e imateriais (rotinas, processos de produção e modo de exercício do poder de comando do empregado) ${ }^{135}$.

É verdade que a Constituição Federal de 1988 contribuiu, e muito, para a reconstrução da noção de meio ambiente do trabalho, despertando um olhar para além dos muros do estabelecimento empresarial e para o próprio trabalhador. Sobre a tutela do meio ambiente do trabalho, tratará o subcapítulo a seguir, que palmilhará os dispositivos legais que evidenciam a preocupação do constituinte e do legislador infraconstitucional com o instituto em comento.

\footnotetext{
${ }^{134}$ BRANDÃO, Cláudio Mascarenhas. Proteção jurídica à saúde do trabalhador: uma necessária (re)leitura constitucional. Revista LTr, São Paulo, v. 74, n. 1, p. 24-29, 2010. p. 28.

${ }^{135}$ Ibidem.
} 
Não se discute também o rico esforço doutrinário, que não precisou se aventurar tanto pelos caminhos da exegese para alinhavar os diversos dispositivos constitucionais e infraconstitucionais dedicados a tutela do meio ambiente e nele encontrar o meio ambiente do trabalho como uma manifestação particular ambiental; uma unidade autônoma, com leis próprias, porém, dependente da estrutura sistêmica, conforme esclarece Guilherme Guimarães Feliciano:

Doutrinariamente, o meio ambiente do trabalho aparece ao lado do meio ambiente natural (constituído pelos elementos físicos e biológicos nativos do entorno: solo, água, ar atmosférico, flora, fauna, e suas interações entre si e com o meio); do meio ambiente artificial (constituído pelo espaço urbano construído, que compreende o conjunto de edificações - espaço urbano fechado - e dos equipamentos públicos - espaço urbano aberto; alguns autores referem, ainda, o meio ambiente rural, relativo ao espaço rural construído); do meio ambiente cultural (constituído pelo patrimônio histórico, artístico, arqueológico, paisagístico e turístico, que agregou valor especial pela inspiração de identidade perante os povos), sendo todos manifestações particulares da entidade meio ambiente, que acima concebíamos como gestalt. ${ }^{136}$

Essa perspectiva sistêmica de que o meio ambiente abarca quatro níveis relevantes - natural, cultural, artificial e do trabalho - encontra fundamento no artigo 225 da Constituição Federal $^{137}$ e sustenta a construção doutrinária de que o meio ambiente do trabalho integra o meio ambiente geral.

Conforme relembra Júlio César de Sá da Rocha, antes mesmo da vigente Constituição Federal, na Conferência em Genebra de 1988 a Organização Internacional do Trabalho já considerava o meio ambiente do trabalho como parte integrante do meio ambiente geral $^{138}$, reconhecendo a influência recíproca dos diversos contextos ambientais, conforme assevera Sebastião Geraldo de Oliveira:

O meio ambiente do trabalho está inserido no meio ambiente geral (art. 200, VII, da Constituição da República), de modo que é impossível alcançar qualidade de vida sem ter qualidade de trabalho, nem se pode atingir meio ambiente equilibrado e sustentável, ignorando o meio ambiente do trabalho. Dentro desse espírito, a Constituição de 1988 estabeleceu expressamente que

\footnotetext{
${ }^{136}$ FELICIANO, Guilherme Guimarães. Meio ambiente do trabalho: aspectos gerais e propedêuticos. Síntese Trabalhista, Porto Alegre, v.14, n. 162, p. 122-153, dez. 2002. p. 126.

${ }^{137}$ FIORILLO, Celso Antonio Pacheco; RODRIGUES, Marcelo Abelha. Direito Ambiental e Patrimônio Genético. Belo Horizonte: Editora Del Rey, 1996.

${ }^{138}$ ROCHA, Júlio César de Sá da. Direito ambiental e meio ambiente do trabalho. Dano, prevenção e proteção jurídica. São Paulo: LTr, 1997. p. 30.
} 
a ordem econômica deve observar o princípio da defesa do meio ambiente $\left(\right.$ art. 170, VI). ${ }^{139}$

Na prática, pode parecer remota essa interdependência entre contextos ambientais insculpida na noção doutrinária de meio ambiente do trabalho, assim como a inter-relação pessoa-ambiente ressaltada neste estudo, ou seja, o trabalhador influindo no meio ambiente do trabalho e este na maneira como trabalhador percebe, experimenta, vivencia e interage com o trabalho e seu meio. No entanto, essa ideia fica mais clara quando se considera que um trabalhador adoecido pela atividade que desempenha será um trabalhador adoecido não apenas no trabalho, mas em casa, na comunidade, no lazer, no mercado de consumo, enfim, seu estado de saúde repercutirá na sua condição humana em todo e qualquer contexto ambiental em que se encontre e faça parte. Isto é, a qualidade do meio ambiente do trabalho repercutirá na qualidade de vida do trabalhador, que está intrinsecamente relacionada também a outros contextos ambientais.

O inverso também é possível. Por exemplo, uma epidemia que atinge uma determinada região onde se encontra instalada uma empresa que emprega trabalhadores regionais, inevitavelmente repercutirá na qualidade de vida dessas pessoas, dentro e fora dos muros da empresa. A situação econômica de uma certa região, estado ou país pode ser um outro exemplo da interdependência entre contextos ambientais, haja vista que as dificuldades econômicas empresariais certamente influenciarão na produção, na quantidade de postos de trabalho, na remuneração e na satisfação com o trabalho, balizada pelo temor do desemprego.

A greve do transporte público ou a precária mobilidade em uma determinada região que imponha ao trabalhador diariamente a utilização de várias conduções para cumprir o trajeto casa-trabalho certamente influenciarão na rotina laboral e na qualidade de vida desse trabalhador.

Por isso, sem essa noção de interdependência não há como se pensar no equilíbrio do meio ambiente do trabalho como um direito fundamental do trabalhador que, por ser parte do meio ambiente geral, encontra-se em vários contextos ambientais que se comunicam e interagem, um influindo no outro, conforme apontou um participante deste estudo:

\footnotetext{
${ }^{139}$ OLIVEIRA, Sebastião Geraldo de. Proteção jurídica á saúde do trabalhador. 4. ed. São Paulo: LTr, 2002. p.
} 129. 
Meio ambiente do trabalho é o local onde a pessoa trabalho. Mas eu vou um pouquinho mais longe, eu acho que o meio ambiente envolve todo o meio ambiente, não só o local onde a pessoa trabalha. São as ruas, o ar condicionado, o equipamento utilizado, a forma de atendimento, as pessoas com que as pessoas tem que trabalhar, a forma mais fácil no atendimento, o que pode gerar um melhor atendimento, o trabalho sendo feito de uma maneira alegre, de uma maneira tranquila, a tendência é fazer um trabalho melhor do que se ele trabalhar sob uma pressão, ou num local muito ruim, com pouca luminosidade... muito quente ou muito frio, tudo isso gera um ambiente de trabalho desagradável. Agora, de uma outra forma, você tem outras coisas que podem tornar esse ambiente desagradável... a pressão, as pessoas que trabalham junto, você não poder se relacionar com a pessoa do lado, não poder conversar, você acaba ficando isolado. No nosso caso de atendimento, você acaba ficando isolado, e isso leva muitas vezes a pessoa a se isolar um pouco do mundo e esquece que o ambiente de trabalho dele é aquele cubículo que ele está. Não é! É tudo mais, o restante todo da empresa, a pessoa que tá trabalhando do lado dele, iluminação, o ar, o rua onde ele trabalho, ruídos, conversas e uma descontração para que ele possa ter um tempo, pelos menos por alguns minutos, de aliviar a cabeça, pensar em outras coisas, poder ligar e falar com a esposas, com os filhos... ter alguns minutos para que ele possa relaxar um pouco, ter essa situação. (Participante: Sindicato).

Não se trata de expandir o alcance do meio ambiente do trabalho, tampouco sugerir uma apropriação pelo Direito do Trabalho de outras dimensões ambientais (natural, artificial e cultural) ou da competência de outras áreas (medicina, psicologia, sociologia, economia, etc.). Trata-se sim - e essa é a proposta deste estudo - de não ignorar a influência de outros contextos ambientais no meio ambiente do trabalho, cujos aspectos, ainda que mais gerais e mediatos, podem repercutir na saúde do trabalhador, que também é parte do meio ambiente e a ele está inseparavelmente vinculado.

\subsubsection{Meio ambiente do trabalho: fundamento legal}

Não obstante a ausência de menção literal ao meio ambiente do trabalho no art. 225 da Constituição Federal ${ }^{140}$, é evidente que a noção de meio ambiente ecologicamente equilibrado abarca todos os níveis ambientais, incluindo o do trabalho, no qual a pessoa passa a maior parte de sua vida ${ }^{141}$.

\footnotetext{
${ }^{140}$ Art. 225. Todos têm direito ao meio ambiente ecologicamente equilibrado, bem de uso comum do povo e essencial à sadia qualidade de vida, impondo-se ao Poder Público e à coletividade o dever de defendê-lo e preservá- lo para as presentes e futuras gerações.

${ }^{141}$ PADILHA, Norma Sueli. Do meio ambiente do trabalho equilibrado. São Paulo: LTr, 2002.
} 
Para João José Sady ${ }^{142}$, embora o aludido dispositivo constitucional não mencione expressamente a garantia e o dever de proteção do meio ambiente do trabalho, com notável esforço hermenêutico a doutrina edificou o entendimento de que o meio ambiente do trabalho integra o meio ambiente geral, conforme se extrai do texto do art. 200, inciso VII, da Constituição Federal: “Ao sistema único de saúde compete, além de outras atribuições, nos termos da lei: (...) VIII - colaborar na proteção do meio ambiente, nele compreendido o do trabalho". Por meio dessa integração sistêmica dos dispositivos constitucionais, incluindo também a previsão contida nos artigos $7^{\circ}$, inciso XXII ${ }^{143}$, e 225 da Constituição Federal, é que se reconhece o meio ambiente do trabalho equilibrado como um direito fundamental do trabalhador; um "bem de uso comum do povo e essencial à sadia qualidade de vida" (art. 225, $\mathrm{CF})$.

Enquanto a Lei $n^{\circ}$ 6.938/81 (Lei de Política Nacional do Meio Ambiente) define meio ambiente como "o conjunto de condições, leis, influências e interações de ordem física, química e biológica, que permite, abriga e rege a vida em todas as suas formas" (art. $3^{\circ}$ ), nem o constituinte, nem o legislador infraconstitucional se atreveram a traçar um conceito de meio ambiente do trabalho, diante da evidente dificuldade de conceituá-lo abarcando toda a complexidade desse microssistema.

A própria definição contida na Lei $\mathrm{n}^{\circ}$ 6.938/81 vacila ao não contemplar os aspectos pessoais (psicológicos e comportamentais) e ambientais (culturais, sociais, econômicos, jurídicos, políticos, etc.) que permeiam o meio ambiente e influenciam em seu equilíbrio. Segundo Júlio César de Sá da Rocha, um conceito de meio ambiente não pode considerar apenas os elementos naturais, "mas também os componentes ambientais humanos, em outras palavras, o ambiente construído pela ação antrópica"144.

Nesse sentido, torna-se difícil traçar um conceito universal, haja vista que cada atividade possui determinadas peculiaridades que requerem diferentes entendimentos de riscos e segurança, os quais variam de acordo com a função exercida e com a especificidade

\footnotetext{
${ }^{142}$ SADY, João José. Direito do meio ambiente de trabalho. São Paulo: LTr, 2000.

${ }^{143}$ Art. $7^{\circ}$. São direitos dos trabalhadores urbanos e rurais, além de outros que visem à melhoria de sua condição social: (...) XXII - redução de riscos inerentes ao trabalho, por meio de normas de saúde, higiene e segurança.

${ }^{144}$ ROCHA, Julio César de Sá da. Direito ambiental do trabalho: mudança de paradigma na tutela jurídica à saúde do trabalhador. São Paulo: LTr, 2002. p. 127.
} 
do ambiente laboral. Ademais, a noção de meio ambiente do trabalho não pode ser imutável, devendo refletir as constantes evoluções sociais e técnicas ${ }^{145}$.

Evidenciando essa complexidade, João José Sady ainda explica que o campo de estudo do meio ambiente do trabalho não é um sistema claramente articulado que possibilita a extração de regras especiais a partir de regras gerais, mas sim o contrário; um sistema de regras de sentido amplo do qual o constituinte extraiu preceitos de caráter pontual e alçou ao nível constitucional ${ }^{146}$.

Justamente por não ser um sistema claramente articulado, por abrigar regras de sentido amplo e por estar a saúde do trabalhador inserida em um vasto campo multidisciplinar, surge a necessidade de se promover estudos multi ou interdisciplinares entre diferentes áreas do conhecimento, como ora aqui se faz quando se propõe uma abordagem de meio ambiente do trabalho através da perspectiva interacional entre Direito do Trabalho e Psicologia Ambiental (subcapítulo 3.2).

\subsubsection{Meio ambiente do trabalho: princípios jurídicos}

Os princípios jurídicos "são ordenações que se irradiam e imantam os sistemas de normas, são (como observam Gomes Canotilho e Vital Moreira) núcleos de condensações nos quais confluem valores e bens constitucionais" ${ }^{147}$. Significam o ponto de partida, o veio, o alicerce que compreende "os fundamentos da Ciência Jurídica em que se firmam as normas originárias ou as leis científicas do Direito" ${ }^{\text {148. }}$.

Para Américo Plá Rodrigues, "um princípio é algo mais geral do que uma norma porque serve para inspirá-la, para entendê-la, para supri-la. E cumpre essa missão relativamente a um número indeterminado de normas"149. Segundo Dalmo de Abreu Dallari,

\footnotetext{
${ }^{145}$ ROCHA, Julio César de Sá da. Direito ambiental do trabalho: mudança de paradigma na tutela jurídica à saúde do trabalhador. São Paulo: LTr, 2002. p. 127.

${ }^{146}$ SADY, João José. Repensando o direito ambiental do trabalho. Revista do Advogado, São Paulo, n. 82, p. 6373, 2005.

${ }^{147}$ SILVA, José Afonso da. Curso de direito constitucional positivo. 22. ed. rev. atual. São Paulo: Malheiros, 2003. p. 92.

${ }^{148}$ MELO, Raimundo Simão de. Direito ambiental do trabalho e a saúde do trabalhador: responsabilidades legais, dano material, dano moral, dano estético, indenização pela perda de uma chance, prescrição. 4. ed. São Paulo: LTr, 2010. p. 51.

${ }^{149}$ PLÁ RODRIGUEZ, Américo. Princípios de Direito do Trabalho. Tradução Wagner D. Giglio. 3. ed. São Paulo: LTr, 2000. p. 37.
} 
ao ressaltar que os princípios jurídicos constitucionais deixaram de ser tratados como meras recomendações ou sugestões, assumindo caráter obrigatórios e exigíveis juridicamente,

uma das mais importantes inovações introduzidas pelo neoconstitucionalismo foi o reconhecimento da natureza jurídica dos princípios referidos expressamente ou implícitos no texto constitucional, igualando-os, em termos de eficácia e imediata exigibilidade, às normas constitucionais. ${ }^{150}$

A elaboração de uma principiologia própria no campo ambiental, com o objetivo fundamental de proteger o meio ambiente e garantir sadia qualidade de vida a toda coletividade, teve início na Suécia com a Conferência de Estocolmo de 1972. Prosseguiu na ECO 92, sediada no Rio de Janeiro, quando se criaram importantes princípios globais, adaptáveis às legislações de cada país, para orientação e aplicação das normas voltadas à proteção do meio ambiente ${ }^{151}$.

No Brasil, a harmonização desses princípios com o ordenamento jurídico pátrio ocorreu por meio do art. 225 da Constituição Federal, que estabeleceu princípios próprios, conferindo autonomia à ciência do Direito Ambiental ${ }^{152}$. Esclarece Guilherme José Purvin de Figueiredo que o Direito Ambiental propõe novos paradigmas de produção e consumo no processo econômico, modificando a relação entre o ser humano e o ambiente de trabalho ${ }^{153}$.

Essa concepção evidencia o fenômeno em estudo, qual seja, a interdependência entre os aspectos macrossistêmicos e o meio ambiente do trabalho, sobretudo porque ambos integram o meio ambiente geral, tanto na perspectiva jurídica sistêmica - conforme Fábio Fernandes ${ }^{154}$, Guilherme Guimarães Feliciano ${ }^{155}$, Norma Sueli Padilha ${ }^{156}$ e Sebastião Geraldo

\footnotetext{
${ }^{150}$ DALLARI, Dalmo de Abreu. A Constituição na vida dos povos: da Idade Média ao século XXI. São Paulo: Saraiva, 2010. p. 320-321.

${ }^{151}$ MELO, Raimundo Simão de. Direito ambiental do trabalho e a saúde do trabalhador: responsabilidades legais, dano material, dano moral, dano estético, indenização pela perda de uma chance, prescrição. 4. ed. São Paulo: LTr, 2010.

152 Ibidem.

${ }^{153}$ FIGUEIREDO, Guilherme José Purvin de. Direito ambiental e a saúde dos trabalhadores. 2. ed. São Paulo: LTr, 2007.

${ }^{154}$ FERNANDES, Fábio. Meio ambiente geral e meio ambiente do trabalho: uma visão sistêmica. São Paulo: LTr, 2009.

155 FELICIANO, Guilherme Guimarães. Tópicos avançados de direito material do trabalho: atualidades forenses. v. 1. São Paulo: Editora Damásio de Jesus, 2006.

${ }^{156}$ PADILHA, Norma Sueli. Do Meio Ambiente do Trabalho Equilibrado. São Paulo: LTR, 2002.
} 
de Oliveira ${ }^{157}$ - como na perspectiva interdependente da Psicologia Ambiental, abordada no subcapítulo 3.2.

Daí a pertinência da abordagem ilustrativa dos principais princípios jurídicos do Direito Ambiental, quais sejam, Princípio da Obrigatoriedade de Intervenção Estatal, Princípio da Prevenção, Princípio da Precaução, Princípio do Poluidor-pagador, Princípio da Informação, Princípio da Educação, Princípio da Participação, Princípio do Desenvolvimento Sustentável e Princípio da Ubiquidade.

Esses princípios, explorados a seguir, serão enfocados sob a perspectiva da potencial contribuição para um meio ambiente do trabalho equilibrado.

O Princípio da Obrigatoriedade de Intervenção Estatal decorre do art. 200, caput, inciso VIII, da Constituição Federal, ao estabelecer que compete ao Sistema Único de Saúde (SUS), além de outras atribuições, colaborar na proteção do meio ambiente do trabalho, nele compreendido o do trabalho, e do art. 225, parágrafo $1^{\circ}$, inciso $\mathrm{V}$, que impõe ao Poder Público o controle da produção, da comercialização e do emprego de técnicas, métodos e substâncias que comportem risco para a vida, a qualidade de vida e o meio ambiente. Em consonância com este Princípio, a Constituição do Estado de São Paulo estabelece o dever do Estado "garantir a saúde e a segurança nos empregados nos ambientes de trabalho" (art. 229, $\left.\S 3^{\circ}\right)$.

O Princípio da Prevenção, informado em 1972 pela Declaração da Conferência das Nações Unidas sobre o Meio Ambiente Humano, de Estocolmo, e também consagrado no art. 225 da Constituição Federal, é doutrinariamente considerado como o princípio nuclear do Direito Ambiental e conduz à "adoção de medidas tendentes a evitar riscos ao meio ambiente e ao ser humano" ${ }^{158}$. Explica Raimundo Simão de Melo que, na seara trabalhista, esse princípio preleciona a orientação dos trabalhadores sobre os riscos ambientais e a disponibilização dos equipamentos adequados de proteção, conforme institui o art. 157 da Consolidação das Leis do Trabalho, cabendo, inclusive, punição para aqueles que,

\footnotetext{
${ }^{157}$ OLIVEIRA, Sebastião Geraldo de. Proteção jurídica á saúde do trabalhador. 4. ed. São Paulo: LTr, 2002.

${ }^{158}$ MELO, Raimundo Simão de. Direito ambiental do trabalho e a saúde do trabalhador: responsabilidades legais, dano material, dano moral, dano estético, indenização pela perda de uma chance, prescrição. 4. ed. São Paulo: LTr, 2010. p. 52.
} 
devidamente orientados, recusam-se em observar as normas de segurança e medicina do trabalho, nos termos do art. 159 celetista $^{159}$.

Quanto ao Princípio da Precaução, este não se confunde com o Princípio da Prevenção.

Segundo Paulo Affonso Leme Machado, previne-se porque são conhecidas as consequências antes de iniciar, prosseguir ou suprimir determinado ato, sendo o nexo causal cientificamente comprovado, por isto certo, ou até mesmo decorrente da lógica. Acrescenta Paulo de Bessa Antunes que "aplica-se a impactos ambientais já conhecidos e que tenham uma história de informação sobre eles"160.

Esses dois princípios são importantes vetores para a apreciação das liminares e tutelas antecipadas em ações que visem à tutela do meio ambiente do trabalho e à preservação da saúde do trabalhador. O Princípio da Precaução, inclusive, é visto como um instrumento de política ambiental baseado na inversão do ônus da prova, consubstanciado no art. $6^{\circ}$, inciso II, do Código de Defesa do Consumidor, para que o suposto autor do dano comprove que a intervenção pretendida não causará prejuízo ao meio ambiente e à saúde do trabalhador ${ }^{161}$.

Quanto à precaução, evita-se porque não se sabe as consequências que determinado ato, empreendimento ou aplicação científica causará ao meio ambiente, considerando a variável espaço-tempo, havendo, pois, incerteza científica não dirimida ${ }^{162}$. Nessas situações, de acordo com Guilherme José Purvin de Figueiredo, "a ausência de certeza científica absoluta não deve servir de pretexto para procrastinar a adoção de medidas efetivas visando a prevenir degradação do meio ambiente"163.

Dito isto, pode-se dizer que o Princípio da Precaução institui o dever de se adotar medidas preventivas, mesmo em situações de incerteza do risco, sob dois fundamentos: (a) uma vez concretizados os danos ambientais é quase impossível restituir o bem ao estado anterior; e (b) a proteção da vida e de qualquer aspecto humano está acima de qualquer

\footnotetext{
${ }^{159}$ MELO, Raimundo Simão de. Direito ambiental do trabalho e a saúde do trabalhador: responsabilidades legais, dano material, dano moral, dano estético, indenização pela perda de uma chance, prescrição. 4. ed. São Paulo: LTr, 2010. p. 52.

${ }^{160}$ ANTUNES, Paulo Bessa. Direito Ambiental. 7. ed. 2. tir. Rio de Janeiro: Lumen Juris, 2005. p. 37.

${ }^{161}$ MELO, Raimundo Simão de. Op. cit.

${ }^{162}$ MACHADO, Paulo Affonso Leme. Direito Ambiental Brasileiro. 13. ed. rev. atual. e ampl. São Paulo: Malheiros Editores, 2005.

${ }^{163}$ FIGUEIREDO, Guilherme José Purvin de. Direito ambiental e a saúde dos trabalhadores. 2. ed. São Paulo: LTr, 2007. p. 60.
} 
aspecto econômico, nos termos do art. 170 da Constituição Federal ${ }^{164}$. Esse Princípio, consagrado na Conferência das Nações Unidas para o Meio Ambiental e o Desenvolvimento (ou ECO 92) com a aprovação dos Princípios 15 e 17, foi agasalhado pela Lei ${ }^{\circ}$ 6.938/81 Lei de Política Nacional do Meio Ambiente (art. $4^{\circ}$, incisos I e IV) e expressamente previsto no Constituição Federal (art. 225, $\$ 1^{\circ}$, inciso V) e na Lei $n^{\circ}$ 9.605/98 - Lei de Crimes Ambientais $\left(\operatorname{art} .54, \S 3^{\circ}\right)$.

Por sua vez, emana do Princípio do Poluidor-pagador o dever de prevenção da ocorrência do dano ambiental e, em não havendo a prevenção, o dever de reparação da forma mais integral possível. Este princípio, agasalhado pela Constituição Federal (art. $225, \S^{\circ}$ ) e pela Lei $\mathrm{n}^{\circ} 6.938 / 81$ (art. $3^{\circ}$, caput e $\S 3^{\circ} \mathrm{c} / \mathrm{c}$ art. $4^{\circ}$, caput e inciso VII), consta também dos Princípios $\mathrm{n}^{\circ} 13$ e $\mathrm{n}^{\circ} 16$ da Declaração edificada na Conferência das Nações Unidas para o Meio Ambiental e o Desenvolvimento (ou ECO 92).

Raimundo Simão de Melo evidencia três aspectos relacionados ao Princípio do Poluidor-pagador: (a) responsabilidade civil objetiva, prevista na Lei $n^{\circ}$ 6.938/81 e recepcionada pela Constituição Federal; (b) prioridade da reparação específica do dano ambiental, ou seja, buscar primeiramente a reparação do dano e, apenas diante da impossibilidade, substituí-la por uma indenização compensatória; e (c) responsabilidade solidária de todos aqueles que, direta ou indiretamente, se beneficiaram da atividade poluidora, nos termos do art. 225, parágrafo $3^{\circ}$, da Constituição Federal e art. $3^{\circ}$, inciso IV, da Lei $\mathrm{n}^{\mathrm{o}} 6.938 / 81^{165}$.

No plano laboral, deve-se entender que o sujeito passivo direto do dano ambiental é o trabalhador, enquanto o sujeito ativo pode ser o empregador ou até mesmo um terceiro (pessoa física ou jurídica) que, vinculado à relação de emprego ou de trabalho, intervenha de forma prejudicial no meio ambiente do trabalho onde se encontra o trabalhador. Contudo, não se discute que a responsabilidade será do empregador-poluidor, por força do disposto no art. $2^{\circ}$ da Consolidação das Leis do Trabalho.

\footnotetext{
${ }^{164}$ MELO, Raimundo Simão de. Direito ambiental do trabalho e a saúde do trabalhador: responsabilidades legais, dano material, dano moral, dano estético, indenização pela perda de uma chance, prescrição. 4. ed. São Paulo: LTr, 2010.

${ }^{165}$ Ibidem.
} 
Do Princípio da Participação, também denominado por Fábio Fernandes ${ }^{166}$ de Princípio da Participação Popular, extrai-se o dever não apenas do Estado, mas de toda a sociedade de proteger e preservar o meio ambiente através de ações e parcerias conjuntas. Não se trata de uma fragmentação de responsabilidades em que cada um atua isoladamente, mas sim da união de esforços de vários atores vinculados por esse objetivo (Estado, sindicatos, trabalhadores, empregadores e toda a sociedade em geral), haja vista a ineficiência do Poder Público e a precária conscientização política e social da sociedade na defesa desse direito fundamental.

No âmbito laboral, o Princípio da Participação evidencia-se no dever do Estado, através do Ministério do Trabalho e Emprego, de elaborar normas de proteção e prevenção dos ambientes de trabalho (art. 156 CLT), de orientar trabalhadores e empregadores e de fiscalizar quanto ao cumprimento dessas normas, impingindo sanções pecuniárias (art. 201 CLT) e administrativas (art. 161 CLT) se verificado o descumprimento. Evidencia-se, ainda, no papel do SUS na execução de tarefas de vigilância sanitária e epidemiologia, inclusive no campo da saúde do trabalhador, colaborando para a proteção do meio ambiente, nele compreendido o do trabalho, conforme prevê o art. 200, inciso II e VII da Constituição Federal. E na esfera judicial, com a legitimação ativa solidária da União, dos Estados, do Distrito Federal, dos Municípios, do Ministério Público e das sociedades civis (por exemplo, sindicatos) na defesa do meio ambiente do trabalho.

A participação também inclui os sindicatos, nos termos do art. $8^{\circ}$, inciso III, da Constituição Federal, na defesa dos interesses coletivos e individuais da categoria representada no que diz respeito ao meio ambiente do trabalho, tanto na seara judicial com na administrativa; e os trabalhadores, nas ações de prevenção de riscos ambientais junto à Comissão Interna de Prevenção de Acidentes (CIPA), constituída em parte por representantes eleitos pelos próprios trabalhadores.

Raimundo Simão de Melo $^{167}$ aponta que a informação sobre as condições ambientais, a educação ambiental em todos os níveis de ensino e a conscientização pública acerca da preservação do meio ambiente, asseguradas pelo art. $225, \S 1^{\circ}$, inciso VI, da

\footnotetext{
${ }^{166}$ FERNANDES, Fábio. Meio ambiente geral e meio ambiente do trabalho: uma visão sistêmica. São Paulo: LTr, 2009.

${ }^{167}$ MELO, Raimundo Simão de. Direito ambiental do trabalho e a saúde do trabalhador: responsabilidades legais, dano material, dano moral, dano estético, indenização pela perda de uma chance, prescrição. 4. ed. São Paulo: LTr, 2010.
} 
Constituição Federal, decorrem do Princípio da Participação e justificam a natureza difusa do meio ambiente equilibrado como bem de uso comum do povo, cuja degradação alcança toda a sociedade. Fábio Fernandes ${ }^{168}$ encampa o mesmo entendimento, ao abordar a informação e a educação ambiental conjuntamente com o Princípio da Participação.

Por outro lado, Guilherme José Purvin de Figueiredo ${ }^{169}$ eleva a educação ambiental ao patamar principiológico, inserindo nesse rol o Princípio da Educação Ambiental, assim reconhecido pelo art. $2^{\circ}$, inciso X, da Lei $n^{\circ} 6.938 / 91^{170}$, e o Princípio da Informação, que aduz estar presente em quase todas as recentes Convenções da Organização Internacional do Trabalho, em Diretivas da União Europeia, em Resoluções do MERCOSUL, leis e normas brasileiras.

Quanto às Convenções da Organização Internacional do Trabalho, aponta, por exemplo: a Convenção sobre a proteção dos trabalhadores contra as radiações ionizantes Genebra, 22/06/60; a Convenção sobre a proteção sobre os riscos de intoxicação devido ao benzeno - Genebra, 23/06/71; e a Convenção sobre a proteção dos trabalhadores contra os riscos profissionais devido à poluição do ar, do ruído e das vibrações nos locais de trabalho Genebra, 20/06/77).

Com relação à União Europeia, aponta, ilustrativamente, a Diretiva-Quadro 89/391/CEE, que exige a ampla informação dos trabalhadores e seus representantes dos riscos à segurança e à saúde no local de trabalho e as medidas necessários para reduzi-los ou suprimi-los. E ao MERCOSUL, o art. $6^{\circ}$ da Resolução CPC/REC n ${ }^{\circ} 27 / 00$, que recomenda o aperfeiçoamento de mecanismos legais para garantir às partes envolvidas no processo produtivo e às suas entidades representativas o acesso a dados e informações relativos a riscos à saúde e ao meio ambiente.

$\mathrm{E}$, quanto ao ordenamento jurídico pátrio, aponta o jurista: o art. $4^{\circ}$, inciso $\mathrm{V}$, da Lei $n^{\circ}$ 6.938/91, que estabelece, como um dos objetivos da Política Nacional do Meio

\footnotetext{
${ }^{168}$ FERNANDES, Fábio. Meio ambiente geral e meio ambiente do trabalho: uma visão sistêmica. São Paulo: LTr, 2009.

${ }^{169}$ FIGUEIREDO, Guilherme José Purvin de. Direito ambiental e a saúde dos trabalhadores. 2. ed. São Paulo: LTr, 2007.

${ }^{170}$ Art $2^{\circ}$. A Política Nacional do Meio Ambiente tem por objetivo a preservação, melhoria e recuperação da qualidade ambiental propícia à vida, visando assegurar, no País, condições ao desenvolvimento sócioeconômico, aos interesses da segurança nacional e à proteção da dignidade da vida humana, atendidos os seguintes princípios: (...) X - educação ambiental a todos os níveis de ensino, inclusive a educação da comunidade, objetivando capacitá-la para participação ativa na defesa do meio ambiente.
} 
Ambiente, "a difusão de tecnologias de manejo do meio ambiente, a divulgação de dados e informações ambientais e a formação de uma consciência pública sobre a necessidade de preservação da qualidade ambiental e do equilíbrio ecológico".

Há que se lembrar ainda do art. 19, parágrafo $2^{\circ}$, da Lei $n^{\circ} 8.213 / 91$, que dispõe sobre o "dever da empresa prestar informações pormenorizadas sobre os riscos da operação a executar e do produto a manipular".

O dever de informação também está previsto na NR 5, que regula a CIPA, ao estabelecer: a atribuição de divulgar aos trabalhadores informações sobre segurança e saúde no trabalho (item 5.16, f), requisitar ao empregador o exame das informações acerca de questões que interfiram no equilíbrio dessas condições (item 5.16, m) e o dever da empresa contratante adotar medidas para que as contratadas, suas CIPA, designados e trabalhadores recebam informações sobre os ricos labor-ambientais e medidas de proteção adequadas (item $5.49)$

Os itens 9.5.1 e 9.5.2 da NR 9, sobre o Programa de Prevenção de Riscos Ambientais (PPRA), estabelecem sucessivamente que "os trabalhadores interessados terão o direito de apresentar propostas e receber informações e orientações a fim de assegurar a proteção aos riscos ambientais identificados na execução do PPRA" e "os empregadores deverão informar os trabalhadores de maneira apropriada e suficiente sobre os riscos ambientais que possam originar-se nos locais de trabalho e sobre os meios disponíveis para prevenir ou limitar tais riscos e para proteger-se dos mesmos"; e, por fim, a letra "c" do item 1.7 da NR 1, que dispõe sobre o dever do empregador de:

c) informar aos trabalhadores:

I - os riscos profissionais que possam originar-se nos locais de trabalho;

II - os meios para prevenir e limitar tais riscos e as medidas adotadas pela empresa;

III - os resultados dos exames médicos e de exames complementares de diagnóstico aos quais os próprios trabalhadores forem submetidos;

IV - os resultados das avaliações ambientais realizadas nos locais de trabalho.

Por oportuno, há também que se lembrar, sobretudo diante da abordagem do presente estudo, das letras "c" e "d" do item 6.1.2 do Anexo II da NR 17, que abordam o dever de incluir na capacitação dos teleoperadores "informações sobre os sintomas de 
adoecimento que possam estar relacionados a atividade de teleatendimento/telemarketing, principalmente os que envolvem o sistema osteomuscular, a saúde mental, as funções vocais, auditivas e acuidade visual dos trabalhadores" e "informações sobre a utilização correta dos mecanismos de ajuste do mobiliário e dos equipamentos dos postos de trabalho, incluindo orientação para alternância de orelhas no uso dos fones mono ou biauriculares e limpeza e substituição de tubos de voz".

O Princípio do Desenvolvimento Sustentável, também denominado por Guilherme José Purvin de Figueiredo como Princípio do Desenvolvimento Sustentado ${ }^{171}$, foi consagrado na Conferência das Nações Unidas para o Meio Ambiental e o Desenvolvimento (ou ECO 92) com a aprovação do Princípio no 3, ao dispor que "o direito ao desenvolvimento deve ser realizado de modo a satisfazer às necessidades relativas ao desenvolvimento ao meio ambiente das gerações presentes e futuras", e do Princípio $n^{\circ} 4$, que apresenta a seguinte redação: "Para se alcançar o desenvolvimento sustentável, a proteção do meio ambiente deve constituir parte integrante do processo de desenvolvimento e não pode ser considerada isoladamente em relação a ele".

Evidenciando a natureza de um direito intergeracional, busca este princípio a compatibilização do desenvolvimento econômico com a preservação e equilíbrio do meio ambiente para a presente e as futuras gerações, nos termos preceituados no art. 225 da Constituição Federal, que recepcionou o art. $4^{\circ}$, incisos I, IV e V da Lei $n^{\circ}$ 6.938/81. Em outras palavras, citando Fábio Fernandes, "não se quer impedir o desenvolvimento, pois este é inerente à natureza humana, mas sim evitar que esse desenvolvimento seja selvagem e possa ser exercido para o bem de todos por meio de um uso racional dos ecossistemas" ${ }^{\text {"172 }}$.

Na perspectiva laboral, o Princípio do Desenvolvimento Sustentável implica na coexistência harmônica entre economia e meio ambiente do trabalho, para a garantia de um emprego digno, promotor de qualidade de vida para os trabalhadores. Conforme Fábio Fernandes, focaliza tanto a proteção dos recursos naturais como do próprio meio ambiente do trabalho para a preservação da saúde do trabalhador, por meio da compatibilização dos princípios do Direito do Trabalho e da livre iniciativa ${ }^{173}$.

\footnotetext{
${ }^{171}$ FIGUEIREDO, Guilherme José Purvin de. Direito ambiental e a saúde dos trabalhadores. 2. ed. São Paulo: LTr, 2007.

${ }^{172}$ FERNANDES, Fábio. Meio ambiente geral e meio ambiente do trabalho: uma visão sistêmica. São Paulo: LTr, 2009. p. 59.

${ }^{173}$ Ibidem.
} 
Por fim, o Princípio da Ubiquidade evidencia que a proteção do meio ambiente deve servir como parâmetro em toda política, ação, legislação sobre qualquer atividade, obra ou tema, diante da sua influência na vida na qualidade de vida humana, resguardadas pela Constituição Federal. Esclarece Celso Antonio Pacheco Filho que a proteção do meio ambiente é o epicentro dos direitos humanos e, por isso, "tudo que se pretende fazer, criar ou desenvolver deve antes passar por uma consulta ambiental, enfim, para saber se há ou não a possibilidade de que o meio ambiente seja degradado"174.

Na seara laboral, à luz do Princípio da Ubiquidade, toda intervenção direta ou indireta no meio ambiente do trabalho deve preceder do estudo dos impactos nas condições laborais e, por corolário, na saúde do trabalhador, atrelada à dignidade da pessoa humana, resguardada pela Constituição Federal. Como exemplo, a alteração da organização do trabalho, do próprio sistema produtivo, das leis trabalhistas e da tecnologia a ser utilizada deve ocorrer sem antes examinar quais os impactos dessas intervenções na saúde e na segurança dos trabalhadores, tendo em vista seus impactos no equilíbrio do meio ambiente do trabalho.

Superada a abordagem desses princípios do Direito Ambiental que alcançam o meio ambiente do trabalho, com base na perspectiva da Psicologia Ambiental a seguir explorada, este estudo ainda proporá e justificará mais adiante dois novos princípios que, na visão deste autor, devem integrar o rol principiológico anteriormente examinado para uma necessária compreensão mais abrangente da complexa interação pessoa-ambiente.

\subsection{O meio ambiente do trabalho sob a perspectiva da Psicologia Ambiental}

O campo de estudo das relações pessoa-ambiente é indiscutivelmente multidisciplinar, sendo diversas as ciências que o tomam como objeto de estudo, sobretudo quando se considera que o ambiente é arena e motor do desenvolvimento e da condição humana.

Para se discutir a influência de outras dimensões ambientais correlatas no meio ambiente do trabalho e seus impactos na saúde do trabalhador, propõe este estudo uma

${ }^{174}$ FIORILlO, Celso Antonio Pacheco. Curso de direito ambiental brasileiro. 8. ed. ver. atual. e ampl. São Paulo: Saraiva, 2007. p. 49. 
releitura da noção jurídica de meio ambiente do trabalho, através de uma abordagem interdisciplinar entre Direito do Trabalho e Psicologia Ambiental, buscando melhor compreender a complexidade da interdependência entre contextos ambientais e da interação pessoa-ambiente. Parte-se da premissa de que as características da pessoa e os atributos dos diversos contextos ambientais interagem entre si, influenciando-se mútua e continuamente.

Essa proposta de abordagem interdisciplinar deve ser entendida, conforme já justificado, não como uma sobreposição de ciências ou uma apropriação de competências de outras áreas, mas sim como um processo de investigação palmilhado em duas áreas do conhecimento e dirigida a um problema a elas comum ${ }^{175}$. Visa, portanto, “a abertura de diálogo em outros quadrantes e sob outras justificativas teóricas, compreendendo, sistematicamente, o momento do direito na atualidade e seu impacto sobre a sociedade" ${ }^{176}$.

Sendo o também campo da saúde do trabalhador uma seara eminentemente interdisciplinar, justifica-se a presente intersecção, porque nenhuma área do conhecimento consegue isoladamente abarcar com êxito a complexidade que lhe é peculiar. A respeito, complementam Maria Helena Barros de Oliveira e Luiz Carlos Fadel Vasconcellos:

Não se trata aqui da sobreposição de ciências, que aparentemente percorrem caminhos próprios, métodos específicos e produtos que se completam em si só. Trata-se de buscar-se uma aproximação entre elas, com a ousada criação de um novo campo do conhecimento, que se impõe pelas expressões materiais e factuais que se colocam na vivência humana, no convívio entre iguais e singularmente diferenciados.

\section{(...)}

Falar de Direito e Saúde é ter a compreensão que não esgotamos, ou melhor, sequer iniciamos um caminho que dê conta de tão complexa e fundamental relação. Dependendo do objeto ao qual se dedica este campo do conhecimento, teremos a necessidade do uso de disciplinas já construídas nas duas ciências, adequando-as a esta necessária aproximação.

Por exemplo, ao tratarmos da disciplina saúde pública, vinculada às Ciências da Saúde, seu instrumental técnico, teórico e de intervenção sobre os fatores que põem em risco a saúde coletiva (do público, das populações em geral) se apropria do instrumental técnico, teórico e de intervenção [sic] relacionadas a disciplinas do Direito e, portanto, vinculadas às Ciências Jurídicas. Ou seja, não se opera de forma finalística a saúde pública sem ombreá-la com o

${ }^{175}$ STOKOLS, Daniel; et al. Evaluating transdisciplinary science. Nicotine \& Tobacco Research, Madison, v. 5, n. 1, p. S21-S39, dec. 2003.

${ }^{176}$ ROCHA, Júlio César de Sá da. Direito ambiental do trabalho: mudança de paradigma na tutela jurídica à saúde do trabalhador. São Paulo: LTr, 2002. p. 277. 
Direito (Constitucional, Administrativo, do Trabalho, Ambiental, entre outros) ${ }^{177}$.

O gradual surgimento de trabalhos interdisciplinares no campo de estudos da relação pessoa-ambiente tem enfatizado a necessidade do reagrupamento de disciplinas e o advento de novas formas de atuação em diversas áreas e profissões, constituindo, nas palavras de Gleice Azambuja Elali ${ }^{178}$, um espaço de complementação.

Homero Batista Mateus da Silva também acompanha esse entendimento ao apontar que

\begin{abstract}
O tema abrangido pela segurança e medicina do trabalho é necessariamente multidisciplinar e plurinormativo. Envolve a soma do conhecimento acumulado por diversos estudiosos do relacionamento entre o homem e o ambiente, com suas implicações no campo da medicina e da biologia, os impactos sobre a previdência social e sobre as relações de trabalho, bem como os esforços da engenharia e da arquitetura na busca incessante de condições mais confortáveis para o desenvolvimento do trabalho humano ${ }^{179}$.
\end{abstract}

Valorizando esse encontro de diálogos, Sergio Pinto Martins evidencia a importante relação do Direito do Trabalho com outras ciências, como a Sociologia, a Economia, a Administração de Empresas, a Contabilidade, a Estatística, a Medicina, a Filosofia do Trabalho e, inclusive, a Psicologia que, através da subárea da Psicologia do Trabalho, estuda "as técnicas para adaptação do trabalhador a sua atividade"180.

Pelo fato da Psicologia do Trabalho e da Psicologia Organizacional negligenciarem as dimensões físicas ambientais, priorizou este estudo a abordagem da interrelação pessoa-ambiente por meio da intersecção entre Direito do Trabalho e Psicologia Ambiental.

177 OLIVEIRA, Maria Helena Barros de; VASCONCELLOS, Luiz Carlos Fadel. Direito e saúde Possibilidades de um novo campo na luta pela Saúde do Trabalhador. $3^{\text {a }}$ Conferência Nacional de Saúde do Trabalhador, Brasília, maio 2005. Disponível em: <http://www.hc.ufmg.br/crest/downloads/Coletanea.pdf〉. Acesso em: 28 jun. 2011.

${ }^{178}$ ELALI, Gleice Azambuja. Psicologia e arquitetura: em busca do locus interdisciplinar. Estudos de Psicologia, Natal, v. 2, n. 2, p. 349-362, 1997.

179 SILVA, Homero Batista Mateus da. Curso de Direito do Trabalho aplicado: segurança e medicina do trabalho, trabalho da mulher e do menor. v. 3. Rio de Janeiro: Elsevier, 2009. p. 5.

${ }^{180}$ MARTINS, Sergio Pinto. Direito do Trabalho. 28. ed. São Paulo: Atlas, 2012. p. 34. 
Desde a década de 70, a Psicologia Ambiental, um dos campos de pesquisa e intervenção na Psicologia, dedica-se ao estudo da inter-relação pessoa-ambiente, priorizando os aspectos físicos ambientais ${ }^{181}$. Nos Estados Unidos, originou-se da Psicologia Ecológica de Barker $^{182}$, enquanto na Europa surgiu em decorrência da necessidade de reconstrução das cidades europeias, após a Segunda Guerra Mundial ${ }^{183}$. Desde então, a Psicologia Ambiental passou a se ocupar, tanto em pesquisas quanto em intervenções, da conjunção de dois segmentos - degradação ambiental e planejamento de ambientes construídos - e a apresentar interesse pelos seguintes temas: efeitos do ambiente sobre o comportamento humano; mudanças de atitudes; percepções e comportamentos frente ao ambiente; mudanças e planejamento do ambiente; construção de determinados ambientes para obter certos efeitos sobre o comportamento humano; entre outros ${ }^{184}$.

A concepção de ambiente na perspectiva sistêmica da Psicologia Ambiental caracteriza-se por uma visão multidimensional e compreende tanto componentes físicos (por exemplo, arquitetura, decoração, acústica, iluminação, temperatura, mobiliários, objetivos, características topográficas e climáticas, etc.), como também componentes não físicos (aspectos psicológicos ou pessoais dos usuários, por exemplo, expectativas, motivações, padrões de comportamento, crenças, autoestima, etc.) e aspectos sociais (por exemplo, papéis, atividades e valores dos participantes daquele contexto) ${ }^{185}$.

Para a Psicologia Ambiental, o conceito de ambiente é multidimensional, “compreendendo o meio físico concreto em que se vive, natural ou construído, o qual é indissociável das condições sociais, políticas, culturais e psicológicas daquele contexto específico" ${ }^{186}$. Tal noção encontra sintonia com a etimologia da palavra ambiente - ambi, do

\footnotetext{
${ }^{181}$ MOSER, Gabriel. Psicologia ambiental. Estudos de Psicologia, Natal, v. 3, n. 1, p. 121-130, jan./jun. 1998. CAMPOS-DE-CARVALHO, Mara. Pesquisas contextuais e seus desafios: uma contribuição a partir de investigação sobre arranjos espaciais em creches. Estudos de Psicologia, Natal, v. 8, n. 2, p. 289-297, maio/ago. 2003.

${ }^{182}$ CAMPOS-DE-CARVALHO, Mara. Psicologia ambiental - Algumas considerações. Psicologia: Teoria e Pesquisa, Brasília, v. 9, n. 2, p. 435-447, 1993; FERREIRA, Marcos Ribeiro. Problemas ambientais como desafio para a psicologia. In GÜNTHER, Hartmut; PINHEIRO, José Q.; GUZZO, Raquel Souza Lobo. (Orgs.). Psicologia Ambiental: entendendo as relações do homem com seu ambiente. Campinas: Alínea, 2004.

${ }^{183}$ MELO, Rosane Gabriele C. de. Psicologia ambiental: uma nova abordagem da psicologia. Psicologia-USP, São Paulo, v. 2, n. 1/2, p. 85-103, 1991.

${ }_{184}$ STOKOLS, Daniel. Environmental psychology. Annual Review Psychology, Palo Alto, n. 29, p. 253-295, 1978; CAMPOS-DE-CARVALHO, Mara. Op. cit.

185 CAMPOS-DE-CARVALHO, Mara Ignez; CAVAlCANTE, Sylvia; NÓBREGA, Lana Mara Andrade. Ambiente. In: CAVALCANTE, Sylvia; ELALI, Gleice A. (Orgs). Temas básicos de Psicologia Ambiental. Petrópolis: Vozes, 2011.

${ }^{186}$ Ibidem, p. 28.
} 
latim, significa "de ambos os lados, ao redor de" $" 187$ - e com sua definição na língua portuguesa como "tudo o que rodeia ou envolve por todos os lados os seres vivos ou coisas e constitui o meio em que se vive; o conjunto de condições materiais, culturais, psicológicas e morais que envolve uma ou mais pessoas" ${ }^{\prime 188}$.

Essa visão multidimensional também se aplica ao meio ambiente do trabalho, que está imerso no meio ambiente geral. Sob essa perspectiva sistêmica da Psicologia Ambiental, o equilíbrio do meio ambiente do trabalho não é apenas influenciado pelos aspectos físicos ambientais (por exemplo, arquitetura, arranjo espacial, decoração, acústica, iluminação, temperatura, mobiliários, características topográficas e climáticas, etc.), mas também por aspectos não físicos (psicológicos ou pessoais dos usuários, por exemplo, relações interpessoais, satisfação com o trabalho, identidade com a atividade, apropriação do espaço, etc.) e por aspectos sociais específicos daquele contexto (por exemplo, papéis, atividades e valores dos trabalhadores, etc.).

Para Eric Sundstrom, a relação entre meio ambiente de trabalho e satisfação individual do trabalhador, em geral, sofre considerável influência do ambiente físico laboral e suas características específicas, em razão da interdependência entre os aspectos físicos ambientais e os aspectos psicológicos do trabalhador, que interagem e se modificam constantemente $^{189}$. Todos os aspectos ambientais do meio ambiente do trabalho influenciam o comportamento daqueles que se encontram imersos naquele contexto; por exemplo, o desempenho, a organização do trabalho e o arranjo espacial podem repercutir na satisfação do trabalhador e no seu estado de saúde ${ }^{190}$.

Não bastasse essa malha de influências, o meio ambiente do trabalho também é influenciado por sistemas ambientais mais amplos e mediatos, nos quais se encontra e é inseparavelmente relacionado. Em outras palavras, o meio ambiente do trabalho é envolto pelos sistemas social, jurídico, econômico, cultural e político ${ }^{191}$, que influenciam na sua condição e no seu equilíbrio e por ele também são influenciados.

\footnotetext{
${ }^{187}$ CUNHA, Antônio Geraldo da. Dicionário etimológico Nova Fronteira da Língua Portuguesa. Rio de Janeiro: Nova Fronteira, 1997. p. 38.

${ }^{188}$ HOUAISS. Antônio. Dicionário Houaiss da Língua Portuguesa. Rio de Janeiro: Objetiva, 2001. p. 183.

189 SUNDSTROM, Eric. Work environments: offices and factories. In: STOKOLS, Daniel; ALTMAN, Irwin. (Eds.). Handbook of Environmental Psychology. v.1. New York: Wiley, 1987.

${ }^{190}$ MCCOY, Janetta Mitchell. Work environments. In: STOKOLS, Daniel; ALTMAN, Irwin (Eds.). Handbook of Environmental Psychology, New York: Wiley, 2002. v. 2, p. 443-460.

191 RIVLIN, Leanne G. Olhando o passado e o futuro: revendo pressupostos sobre inter-relações pessoaambiente. Estudos de Psicologia, Natal, v. 8, n. 2, p. 215-220, 2003.
} 
Segue nesse sentido a conceituação de ambiente na perspectiva ecológica de Urie Bronfenbrenner, que é ampla e refere-se a um conjunto de sistemas interdependentes, abrangendo desde contextos imediatos dos quais a pessoa participa (escola, creche, igreja, casa, local de trabalho, etc.) até estruturas sociais específicas e contextos mais amplos, nos quais os ambientes imediatos estão imersos (sistemas econômico, educacional, político, social e jurídico $)^{192}$.

Urie Bronfenbrenner concebe o ambiente "como um arranjo aninhado de estruturas, cada uma contida dentro da outra" ${ }^{193}$, devendo essas estruturas e os processos que ocorrem dentro e entre elas ser vistos como interdependentes e analisados em sistemas. Essa interdependência sistêmica compreende os seguintes contextos, denominados por Bronfenbrenner de settings: microssistema e mesossistema, que contém a pessoa e influenciam diretamente e são por elas influenciados; exossistema e macrossistema, que são contextos mais distais e não contém diretamente a pessoa, porém, agem sobre ela ou envolvem o contexto imediato onde a pessoa se encontra.

De acordo com o teórico, o microssistema é o "complexo de relações entre a pessoa em desenvolvimento e o ambiente em um contexto imediato que contém a pessoa"194. No caso da presente abordagem, o microssistema considerado é o meio ambiente do trabalho, haja vista que se busca examinar a influência de aspectos macrossistêmicos consumeristas no meio ambiente do trabalho e, por conseguinte, seus impactos na saúde do trabalhador. Em outras abordagens, o microssistema poderia ser a casa, a escola ou outros contextos focalizados diretamente em uma investigação.

Por sua vez, Bronfenbrenner define mesossistema como as inter-relações estabelecidas entre os principais contextos em que a pessoa se encontra em um dado momento, influenciando-a direta e/ou indiretamente ${ }^{195}$. É o caso da inter-relação entre escola, igreja, casa, local de trabalho, etc.; por exemplo, o trabalhador submetido a condições precárias de trabalho e que, em virtude disso, encontre-se em estado depressivo, poderá ter seu estado de saúde agravado por problemas familiares, decorrentes da sua insatisfação com o

${ }^{192}$ CAMPOS-DE-CARVALHO, Mara. A metodologia do experimento ecológico. In: PINHEIRO, José Q.; GÜNTHER, Hartmut. (Orgs.). Métodos de pesquisa nos estudos pessoa-ambiente. São Paulo: Casa do Psicólogo, 2008. p. 11-52. p. 17.

193 BRONFENBRENNER, Urie. Toward an experimental ecology of human development. American Psychologist, Washington, v. 32, p. 513-531, 1977. p. 514.

${ }^{194}$ Ibidem, p. 514.

${ }^{195}$ Ibidem. 
trabalho. Tanto a casa como o local de trabalho contém o trabalhador, que influencia e é influenciado por esses dois contextos.

O exossistema é definido como um contexto mais amplo e distal que abarca estruturas sociais específica formais e informais, das quais a pessoa não participa diretamente, contudo, envolvem os contextos imediatos nos quais ela se encontra, influenciando e delimitando-os ${ }^{196}$. São exemplos: o mundo do trabalho, a mídia, as agências governamentais em suas diversas esferas, a distribuição de bens e serviços, o transportes, as redes sociais e de comunicação.

E, por fim, segundo Bronfenbrenner, contextos mais amplos e mediatos - como os sistemas social, jurídico, econômico e político - constituem o macrossistema, que são "protótipos gerais que existem na cultura ou subcultura, os quais estabelecem o padrão para as estruturas e atividades que ocorrem no nível concreto" ${ }^{\text {"197 }}$. Portanto, pode-se entender que o microssistema, mesossistema e o exossistema são manifestações concretas do macrossistema, conforme pode-se observar no organograma a seguir apresentado:

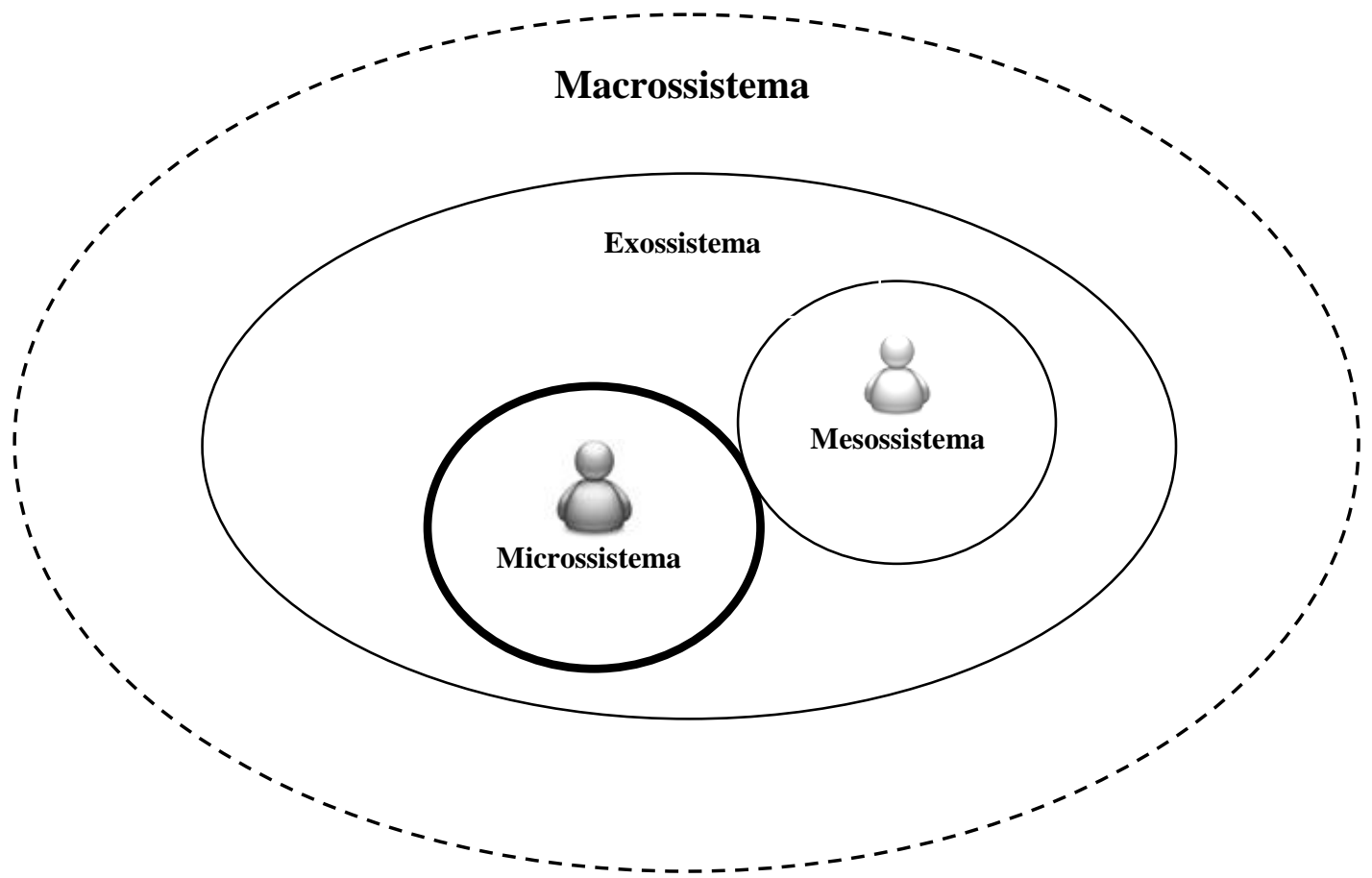

Figura 1. A interdependência contextual na inter-relação pessoa-ambiente.

196 BRONFENBRENNER, Urie. Toward an experimental ecology of human development. American Psychologist, Washington, v. 32, p. 513-531, 1977. p. 514.

${ }^{197}$ Ibidem. 
Note-se que o microssistema e o mesossistema estão imersos no exossistema e todos, no macrossistema.

Embora esses quatro sistemas ambientais sejam intrinsecamente relacionados, priorizou-se neste estudo o exame de apenas dois deles, microssistema e macrossistema, diante da dificuldade de se abarcar em uma mesma abordagem todos os sistemas ambientais propostos por Urie Bronfenbrenner. Evidentemente, o recorte proposto é apenas para fins didático-metodológicos.

Todos os aspectos - sejam eles físicos ou não físicos - e sistemas ambientais imediatos (contexto ambiental investigado) ou mais amplos e distais (outras dimensões ambientais) - produzem tanto mudanças quanto continuidade nas características da pessoa. A perspectiva ecológica de Urie Bronfenbrenner enfatiza essa inter-relação pessoa-ambiente ao considerar a mútua influência de fatores ambientais e pessoais no desenvolvimento humano. Mara Campos-de-Carvalho esclarece que essa interação

implica em processos através dos quais as propriedades da pessoa e do ambiente interagem, produzindo tanto continuidade quanto mudanças nas características da pessoa durante o curso de vida, no modo como ela percebe e negocia com seu ambiente, isto é, mudança e constância nas suas capacidades em descobrir, manter ou alterar as propriedades do ambiente, as quais, por sua vez, também exercem influência nas características da pessoa $^{198}$.

Significa dizer que, tanto a pessoa como o ambiente, nele compreendido o do trabalho, possuem propriedades mutáveis, intra e interdependentes, que dialogam entre si e se influenciam mutuamente, constituindo uma reciprocidade complexa: um domínio exercendo influência no outro ${ }^{199}$.

\subsubsection{Pressupostos da abordagem ecológica: um paradoxo com a noção sistêmica ambiental}

O estudo da inter-relação pessoa-ambiente, sob a perspectiva da abordagem ecológica, compreende quatro pressupostos que ofertam caudalosas contribuições para uma

198 CAMPOS-DE-CARVALHO, Mara. A metodologia do experimento ecológico. In: PINHEIRO, José Q.; GÜNTHER, Hartmut (Orgs.). Métodos de pesquisa nos estudos pessoa-ambiente. São Paulo: Casa do Psicólogo, 2008. p. 14.

${ }^{199}$ Ibidem. 
melhor compreensão da complexidade do meio ambiente do trabalho e sua interação recíproca com o trabalhador: visão bidirecional da relação pessoa-ambiente, interdependência de variáveis, ausência de neutralidade dos contextos ambientais e unicidade do ambiente.

Esses pressupostos podem inclusive contribuir para a análise do impacto do meio ambiente do trabalho na saúde do trabalhador, tanto em abordagens científicas como no trabalho pericial realizado por profissionais da Previdência Social ou habilitados na Justiça do Trabalho, sobretudo em caso de doenças cuja relação com o trabalho ainda é pouco conhecida (por exemplo, doenças psicológicas).

De acordo com o pressuposto da visão bidirecional da relação pessoa-ambiente, "as características da pessoa e do contexto interagem, modificando-se mutuamente" 200 . Portanto, o meio ambiente do trabalho influi no trabalhador e este no meio ambiente do trabalho.

Diversas investigações no campo da Psicologia Ambiental demonstram que as pessoas tendem a modificar o ambiente por elas ocupado, tornando-o mais adequado às suas necessidades e buscando suporte para suas atividades e inter-relações ${ }^{201}$. Essa transação recíproca e extremamente complexa pode ser imediata ou a longo-prazo, em virtude dos valores, normas e hábitos contextuais ${ }^{202}$.

Esse pressuposto também evidencia que a pessoa é parte do ambiente e, por isso, na perspectiva sistêmica, pessoa e ambiente devem ser abordados conjuntamente a medida que são constitutivos um do outro ${ }^{203}$. Em outras palavras, não existe contexto ambiental sem pessoa, nem pessoa sem contexto ambiental, ou melhor, não existe meio ambiente do trabalho sem trabalhador, nem trabalhador sem meio ambiente do trabalho. Por isso, toda noção de meio ambiente do trabalho deve considerar o trabalhador como parte integrante e inseparável.

Por sua vez, o pressuposto da interdependência de variáveis estabelece que não há apenas uma fonte de causalidade na explicação dos fenômenos, mas sim um sistema causal

\footnotetext{
${ }^{200}$ CAMPOS-DE-CARVALHO, Mara. Pesquisas contextuais e seus desafios: uma contribuição a partir de investigação sobre arranjos espaciais em creches. Estudos de Psicologia, Natal, v. 8, n. 2, p. 289-297, maio/ago. 2003. p. 291.

${ }^{201}$ MOSER, Gabriel. Psychologie environnementale: les relations homme-environnement. Bruelas: De Boeck, 2009.

${ }^{202}$ RIVLIN, Leanne G. Olhando o passado e o futuro: revendo pressupostos sobre inter-relações pessoaambiente. Estudos de Psicologia, Natal, v. 8, n. 2, p. 215-220, 2003.

${ }^{203}$ CAMPOS-DE-CARVALHO, Mara Ignez; CAVAlCANTE, Sylvia; NÓBREGA, Lana Mara Andrade. Ambiente. In: CAVALCANTE, Sylvia; ELALI, Gleice A. (Orgs). Temas básicos de Psicologia Ambiental. Petrópolis: Vozes, 2011.
} 
inter-relacionado entremeado por componentes físicos e humanos de um dado contexto ambiental $^{204}$.

Significa dizer, na perspectiva deste estudo, que o meio ambiente do trabalho é composto por vários aspectos, tais como: aspectos físicos (por exemplo, instrumentos, arquitetura, características espaciais, etc.), aspectos sociais (por exemplo, papéis, atividades, valores culturais dos trabalhadores daquele contexto) e aspectos pessoais ou psicológicos (por exemplo, percepção do ambiente, relações interpessoais, satisfação com o trabalho, estímulos, expectativas, apropriação do espaço, experiências pregressas, etc.). Todos esses aspectos influenciam no modo como pessoa e ambiente dialogam e negociam.

Sendo assim, para a explicação causal do comportamento estudado deve-se levar em consideração os diversos aspectos ambientais (físicos, sociais, pessoais ou psicológicos, culturais, econômicos, políticos, jurídicos, etc.), pois o ambiente, incluindo o meio ambiente do trabalho que a ele integra, está envolto pelos "sistemas social, econômico, político e cultural nos quais se encontra e é inseparavelmente relacionado a eles" 205.

Vale dizer que, seja para pesquisa ou intervenção, qualquer aspecto escolhido para análise está relacionado a todos os outros aspectos que integram o ambiente, devendo-se, portanto, considerar esse sistema de interdependência na interpretação dos resultados obtidos $^{206}$.

Quanto ao pressuposto da ausência de neutralidade ambiental, "um contexto ambiental nunca é neutro, mesmo aquele cotidiano e habitual; qualquer um de seus aspectos influencia e é influenciado pelas pessoas usuárias daquele contexto"207. Segundo Leanne G. Rivlin, mesmo que as pessoas não tenham consciência dessa influência, ainda assim poderão

\footnotetext{
${ }^{204}$ CAMPOS-DE-CARVAlHO, Mara Ignez; CAVAlCANTE, Sylvia; NÓBREGA, Lana Mara Andrade. Ambiente. In: CAVALCANTE, Sylvia; ELALI, Gleice A. (Orgs). Temas básicos de Psicologia Ambiental. Petrópolis: Vozes, 2011.

${ }^{205}$ RIVLIN, Leanne G. Olhando o passado e o futuro: revendo pressupostos sobre inter-relações pessoaambiente. Estudos de Psicologia, Natal, v. 8, n. 2, p. 215-220, 2003. p. 217.

${ }^{206}$ CAMPOS-DE-CARVALHO, Mara Ignez; CAVALCANTE, Sylvia; NÓBREGA, Lana Mara Andrade. Ambiente. Op. cit.

${ }^{207}$ CAMPOS-DE-CARVALHO, Mara. Pesquisas contextuais e seus desafios: uma contribuição a partir de investigação sobre arranjos espaciais em creches. Estudos de Psicologia, Natal, v. 8, n. 2, p. 289-297, maio/ago. 2003. p. 291.
} 
ser afetadas pelo ambiente ${ }^{208}$; e mesmo que a pessoa não aja ou fale, isso não significa que sua presença não seja capaz de modificá-lo ${ }^{209}$.

Mara Ignez Campos-de-Carvalho, Sylvia Cavalcante e Lana Mara Andrade Nóbrega esclarecem que

Os contextos ambientais não são isentos de valores. Por exemplo, sua organização transmite significações, tais como as intenções e valores das pessoas que os construíram e os controlam; desta forma, a organização do ambiente gera expectativas sobre quais pessoas serão as usuárias e quais comportamentos se espera que ocorram. Os ambientes também situam a pessoa social, cultural e economicamente e, assim, participam das construção de sua identidade pessoal. Por sua vez, o nível sócio-econômicocultural condiciona os papéis sociais e laborais, as expectativas, percepções, sentimentos e ações das pessoas de um dado contexto ambiental ${ }^{210}$.

Dito isto, pode-se inferir que os aspectos sociais, econômicos, culturais e jurídicos condicionam os papéis, as expectativas, percepções, sentimentos e ações das pessoas (trabalhadores, empregadores, etc.) que se encontram no meio ambiente do trabalho.

Com relação ao pressuposto da unicidade do ambiente, apesar da existência de vários aspectos ambientais interdependentes, como já descrito no pressuposto da interdependência de variáveis, todos eles são percebidos em conjunto pela pessoa ${ }^{211}$. Embora haja uma relação transacional pessoa-ambiente, esses múltiplos aspectos constituem o ambiente em seu todo e assim são vivenciados pelas pessoas, proporcionando um sentido de "campo unitário" "212. Selecionar um desses aspectos ambientais impõe-se somente por questões metodológicas para pesquisa ou intervenção, diante da dificuldade de se abarcar todos os aspectos de uma só vez e em um único estudo.

Não existe um meio ambiente do trabalho físico apartado de suas dimensões social, cultural, econômico, jurídica, entre outras. Contudo, "não significa que suas dimensões

\footnotetext{
${ }^{208}$ RIVLIN, Leanne G. Olhando o passado e o futuro: revendo pressupostos sobre inter-relações pessoaambiente. Estudos de Psicologia, Natal, v. 8, n. 2, p. 215-220, 2003.

${ }^{209}$ CAMPOS-DE-CARVALHO, Mara Ignez; CAVALCANTE, Sylvia; NÓBREGA, Lana Mara Andrade. Ambiente. In: CAVALCANTE, Sylvia; ELALI, Gleice A. (Orgs). Temas básicos de Psicologia Ambiental. Petrópolis: Vozes, 2011.

210 Ibidem, p. 39.

${ }^{211}$ CAMPOS-DE-CARVALHO, Mara. Pesquisas contextuais e seus desafios: uma contribuição a partir de investigação sobre arranjos espaciais em creches. Estudos de Psicologia, Natal, v. 8, n. 2, p. 289-297, maio/ago. 2003. p. 291.

${ }^{212}$ RIVLIN, Leanne G. Op cit., p. 217.
} 
não possam ser lembradas separadamente, e sim que a natureza fenomenológica da experiência proporciona um sentido de campo unitário" ${ }^{213}$.

Este pressuposto não é tão estranho às ciências jurídicas, sobretudo ao Direito Ambiental. Basta recordar a perspectiva sistêmica construída doutrinariamente, já exposta nas linhas anteriores, segundo a qual o ambiente geral, que é único, abarca quatro níveis relevantes interligados: natural, cultural, artificial e do trabalho. Segundo João José Sady, “essa separação dá-se, todavia, apenas para fins didático-classificatórios, uma vez que é preciso ver o bem jurídico meio ambiente como um conjunto de interações em marcha, em que a degradação de um setor acaba por caldear-se para outro"214.

Todavia, considera-se como principal contribuição da perspectiva da abordagem ecológica o pressuposto da unicidade do ambiente, que diz respeito à interdependência multidimensional (social, cultural, econômica, jurídica, etc.) de cada um desses níveis ambientais.

\subsection{O Princípio da Bidirecionalidade e o Princípio da Interdependência como propostas deste estudo}

Diversos fundamentos suscitados anteriormente neste Capítulo, sobretudo aqueles compreendidos na perspectiva da abordagem ecológica de Urie Bronfenbrenner, levaram este estudo a propor a inserção de dois novos princípios jurídicos no rol principiológico ambiental: Princípio da Bidirecionalidade e Princípio da Interdependência.

Esses dois novos postulados servem a todo estudo que se propuser a fazer uma análise multidimensional da inter-relação pessoa-ambiente, com vista à interação entre os diversos contextos ambientais e seus impactos no comportamento humano. Servem também para estimular peritos previdenciários e judiciais a se atentarem para a complexidade da interrelação trabalhador e do meio ambiente do trabalho, no exame do nexo causal entre a atividade profissional e a doença, sobretudo a atípica, e não apenas do nexo etiológico. Devem ser considerados tanto no planejamento de intervenções no meio ambiente do trabalho como na elaboração e na interpretação de normas de saúde e segurança no trabalho.

${ }^{213}$ RIVLIN, Leanne G. Olhando o passado e o futuro: revendo pressupostos sobre inter-relações pessoaambiente. Estudos de Psicologia, Natal, v. 8, n. 2, p. 215-220, 2003.

${ }^{214}$ SADY, João José. Direito do meio ambiente de trabalho. São Paulo: LTr, 2000. p. 17. 
Constituem a base teórica do presente estudo para o exame da interação do meio ambiente do trabalho com outras dimensões ambientais, inclusive macrossistêmicas, e seus impactos no comportamento e na saúde do trabalhador.

Enquanto para a Psicologia Ambiental a inter-relação pessoa-ambiente e a interdependência de variáveis causais são pressupostos da abordagem ecológica, a essência desses dois pressupostos é proposta neste estudo sob a forma de princípio.

Um pressuposto, diriam os léxicos, é uma suposição por antecipação, uma pressuposição. Deve ser entendido como uma condição extrínseca ao objeto, podendo ser anterior (pressupostos de existência), concomitante ou posterior a ele (pressupostos de validade e eficácia $)^{215}$.

No entender deste autor, a inter-relação pessoa ambiente e a interdependência de contextos e sistemas ambientais não são extrínsecas ao meio ambiente do trabalho, mas sim inerentes. Primeiro, porque não existe meio ambiente do trabalho sem trabalhador e viceversa; segundo, porque a construção doutrinária labor-ambiental já consolidou o entendimento de que o meio ambiente é único e o meio ambiente do trabalho é apenas uma de suas manifestações particulares. Assim sendo, a inter-relação pessoa-ambiente e a interdependência entre sistemas e contextos ambientais são indissociáveis da noção de meio ambiente, nele compreendido o do trabalho.

Por isso a proposta sob a forma de princípio, que é algo mais geral e universal do que a norma e pode até mesmo a ela preexistir. Por entendermos que esses dois postulados sugeridos são verdades fundantes, máximas da relação entre o ser humano e o seu entorno, adotou-se as vestes do princípio e não as do pressuposto; porque além deles servirem para a análise de uma situação concreta, entendemos também que eles são essenciais na elaboração e na interpretação das normas de saúde e segurança no trabalho, ou até mesmo para suprir eventual lacuna existente nessa seara.

O Princípio da Bidirecionalidade pessoa-ambiente parte da premissa de que a pessoa é parte integrante e inseparável do ambiente e não apenas nele se encontra. Pessoa e ambiente se relacionam e se influenciam recíproca e continuamente.

\footnotetext{
${ }^{215}$ MELLO, Celso Antônio Bandeira de. Curso de Direito Administrativo. 29. ed. São Paulo: Malheiros, 2012.
} 
Ignorar que o trabalhador é parte constitutiva do meio ambiente do trabalho é descartar toda interação entre a pessoa e seu meio, desprezando todos os aspectos pessoais (comportamentais e psicológicos) que influenciam na maneira como o trabalhador enxerga, vivencia e negocia com o contexto laboral onde passa grande parte do seu dia.

Para Maria Clotilde Rossetti-Ferreira, Katia de Souza Amorim e Ana Paula Soares da Silva, "não se pode pensar o contexto sem considerar as pessoas que dele participam e as interações que nele se estabelecem" 216 . As "relações pessoa-meio são compreendidas como mutuamente constitutivas", evidenciando que pessoa e meio se constroem e se transformam recíproca e dialeticamente ${ }^{217}$. Certo é, nessa perspectiva, que o meio ambiente do trabalho é arena e motor para o desenvolvimento humano, "que se dá por meio das interações estabelecidas pelas pessoas em contextos social e culturalmente organizados"218.

Diversos institutos que integram o campo do Direito do Trabalho e da saúde do trabalhador, como o dano moral, o assédio moral e o assédio sexual só existem em função da perspectiva interacional entre a pessoa e seu contexto laboral, pois é impossível discuti-los sem considerar os atributos da pessoa humana. Os aspectos psicológicos e comportamentais, inerentes ao ser humano, no caso ao trabalhador, também integram o meio ambiente do trabalho e influenciam no seu equilíbrio, uma vez que o trabalhador é ser humano. E, nas palavras de Maria Clotilde Rossetti-Ferreira, Katia Souza Amorim e Ana Paula Soares da Silva, o ser humano se constrói e se desenvolve na relação com o contexto, com o mundo e com outro ${ }^{219}$.

Significa dizer que "o entendimento do meio ambiente do trabalho estabelece-se com a percepção do espaço do trabalho e, mais ainda, do próprio trabalhador, na medida em que não existe tal ambiente sem o ser humano" ${ }^{220}$, pois as condições internas do trabalhador influenciam e são influenciadas pelas condições externas, evidenciando, pois, uma interação $^{221}$.

\footnotetext{
${ }^{216}$ ROSSETTI-FERREIRA, Maria Clotilde; AMORIM, Katia de Souza; SILVA, Ana Paula Soares da. Rede de significações: alguns conceitos básicos. in: ROSSETTI-FERREIRA, Maria Clotilde et al. (Orgs.) Rede de significações e o estudo do desenvolvimento humano. Porto Alegre: Artmed, 2004. p. 23-34. p. 26.

${ }^{217}$ Ibidem, p. 26.

${ }^{218}$ Ibidem, p. 23.

${ }^{219}$ Ibidem.

${ }^{220}$ Ibidem, p. 130.

${ }^{221}$ ROSSIT, Liliana Allodi. O meio ambiente de trabalho no direito ambiental brasileiro. São Paulo: LTr, 2001. $216 \mathrm{p}$.
} 
Por força da Convenção $\mathrm{n}^{\mathrm{o}} 155$ da Organização Internacional do Trabalho ${ }^{222}$, ratificada pelo Brasil, a compreensão dessa inter-relação pessoa-ambiente é vista também no plano de ação que deve ser adotado por cada estado como política nacional em matéria de segurança e saúde dos trabalhadores e o meio ambiente do trabalho, através das seguintes medidas, conforme aponta Otavio Pinto e Silva:

treinamento das pessoas envolvidas com a obtenção dos níveis adequados de higiene e segurança; a comunicação e cooperação entre as pessoas envolvidas; e a proteção dos trabalhadores e de seus representantes contra medidas disciplinares em face de sua atuação na busca de objetivos de redução dos riscos inerentes ao trabalho ${ }^{223}$.

Se o tema saúde e a segurança no trabalho integra o campo de estudo do Direito do Trabalho, como estudá-lo sem examinar a inter-relação pessoa-ambiente, concentrando-se apenas nos aspectos físicos ambientais? Apesar de raramente se conferir na construção doutrinária a menção do trabalhador como parte integrante do meio ambiente do trabalho, não se deve ignorar que o ambiente laboral faz parte da condição humana e é reinventado todos os dias pela atividade produtiva, fazendo parte da vida do ser humano e de sua sobrevivência como espécie ${ }^{224}$.

Alguns participantes deste estudo, Gestores de Recursos Humanos, embora não tivessem apontado diretamente o trabalhador como parte integrante do meio ambiente do trabalho, ao defini-lo fizeram menção a elementos psicológicos e comportamentais humanos, demonstrando, ainda que inconscientemente em um primeiro momento, que o trabalhador é parte integrante e inseparável do locus laboral. Ainda assim, definiram o meio ambiente do trabalho como se o trabalhador nele estivesse e não dele fizesse parte, conforme se observa nos seguintes recortes:

Meio ambiente do trabalho é o meio em que as pessoas interagem para realizar suas atividades. Envolve os fatores físicos e psicológicos, desde o material de trabalho, a relação com os colegas, até o reconhecimento profissional (Participante: RH1).

Meio ambiente do trabalho é tudo aquilo que afeta direta ou indiretamente sua atividade, ou seja, mobiliário, todo material disposto para

\footnotetext{
222 ORGANIZAÇÃO INTERNACIONAL DO TRABALHO. Convenção $n^{\circ} 155.20$ jun. 2002. Disponível em: <http://www.ilo.org/ilolex/cgi-lex/convde.pl?P155>. Acesso em: 29 jun. 2011.

${ }^{223}$ SILVA, Otavio Pinto e. Meio ambiente e saúde do trabalhador. Revista do TRT da $2^{a}$ Região, São Paulo, n. 4/2010, p. 69-119. p. 70.

${ }^{224}$ SADY, João José. Repensando o direito ambiental do trabalho. Revista do Advogado, São Paulo, n. 82, p. $63-$ $73,2005$.
} 
desenvolvimento da atividade, relação interpessoal, tanto com público interno quanto público externo (Participante: RH2).

Entendo como o local onde as pessoas exercem suas atividades, envolvendo as instalações físicas do local, onde devem oferecer um ambiente saudável para a prestação do serviço (Participante: RH3).

O lugar onde passamos maior parte de nosso tempo, meio de relacionamentos, aprendizagem, conhecimento e avaliação profissional e pessoal que influencia muito na formação de profissionais (Participante: RH4).

No mesmo compasso, seguem os conceitos ofertados por dois outros participantes, Magistrados do Trabalho:

Entendo que é o espaço que abarca a estrutura física e também os relacionamentos de trabalho; não somente os aspectos físicos (Participante: MT2.)

O meio ambiente do trabalho pra mim é... uma espécie de meio ambiente como um todo, ou seja, qualquer interação de elementos e aí não envolve apenas o aspecto físico, mas também a estrutura dinâmica e humana desse ambiente, de forma que o ambiente do trabalho seria esse conjunto entre o espaço físico e condições relacionadas a estrutura de relacionamento humano em que labor se desenvolve (Participante: MT3)

Mais além, outro participante, integrante do quadro da Magistratura do Trabalho, ainda relacionou o organismo vivo do trabalhador com o equilíbrio do meio ambiente do trabalho, considerando a influência dos aspectos psicológicos e comportamentais em um determinado contex to laboral:

É um conceito bastante amplo, bastante aberto. Mas eu penso muito em equilíbrio. Quando me vem à mente, a melhor palavra, minha melhor definição é equilíbrio. O equilíbrio envolve, evidentemente, os elementos químicos, físicos, mas também envolve a harmonia do relacionamento. Então um meio ambiente do trabalho pode estar negligenciado, desgastado, sem que haja um derramamento de mercúrio ou uma poluição sonora no local, bastando apenas que haja um chefe neurótico, por exemplo, ou que haja uma gestão pelo temor... ou a gestão pela pressão. Então, a partir dessa premissa do equilíbrio, meio ambiente se torna sinônimo de harmonia (Participante: MT1).

Quando questionados sobre quais aspectos ambientais (geográficos, arquiteturaistecnológicos e socioculturais) e pessoais (biogenéticos, comportamentais e psicológicos) integravam o meio ambiente do trabalho, todos os participantes deste estudo apontaram na 
lista que lhes foi apresentada as alternativas "aspectos psicológicos" e "aspectos comportamentais". Apenas um participante não assinalou a alternativa "aspectos biogenéticos", sob a justificativa de que considerá-lo como aspecto integrante do meio ambiente do trabalho seria, em alguns casos, admitir a prática de condutas discriminatórias, conforme a seguir se observa:

\begin{abstract}
Excepcionalmente sim, normalmente não. Eu acredito na igualdade de chances, acredito muito que um jovem pode liderar, acredito muito que uma mulher pode liderar uma equipe de homens, um homem pode liderar uma equipe de mulheres, uma pessoa portadora de deficiente, uma pessoa com um histórico de doenças. Excepcionalmente eu poderia ver um constrangimento de uma mulher num vestiário feminino. Um constrangimento de um homem num serviço doméstico, o salva vidas com limitações físicas de limitação. No mais, esse item não poderia influenciar o meio ambiente, nem positivo nem negativo.
\end{abstract}

Contudo, entende-se que os aspectos biogenéticos integram os fatores pessoais do meio ambiente do trabalho, não no sentido de determinar o sucesso ou o insucesso de certo trabalhador naquele contexto, mas tão somente porque também deverão ser considerados para se alcançar condições de igualdade e dignidade no trabalho. Por isso, compõem o meio ambiente do trabalho e influenciam no seu equilíbrio. Tome-se como exemplo um trabalhador, com deficiência física, que exerce suas atividades em um estabelecimento sem qualquer adaptação para sua mobilidade; ou até mesmo um trabalhador com baixa imunidade que exerce suas atividades em um ambiente insalubre. Nos dois casos, os aspectos biogenéticos apresentados poderão comprometer a saúde daqueles trabalhadores (o ambiente influindo na pessoa) ou justificar intervenções para garantir condições adequadas de trabalho (a pessoa influindo no ambiente).

Gisele Rodrigues Ferreira também considera que a tutela jurídica do meio ambiente do trabalho se estende desde a qualidade do ambiente físico interno e externo, até as relações interpessoais e a saúde física e mental do trabalhador, integrando à noção atributos inerentes ao trabalhador (aspectos psicológicos e comportamentais) ${ }^{225}$.

Nessa mesma esteira, palmilhando o pressuposto da indissociabilidade de ambiente natural, artificial, cultural e do trabalho, Norma Sueli Padilha inclui os aspectos psíquicos da pessoa à sua concepção de meio ambiente, junto dos aspectos físicos e sociais,

\footnotetext{
${ }^{225}$ FERREIRA, Gisele Rodrigues. Direito ambiental do trabalho. Boletim Jurídico, Uberaba, v. 3, n. 117, 2005. Disponível em: <http://www.boletimjuridico.com.br/doutrina/texto.asp?id=542>. Acesso em: 24 jun. 2011.
} 
que proporcionam condições necessárias e suficientes para que o ser humano se desenvolva na sua plenitude, conforme a seguir se observa:

\begin{abstract}
Podemos afirmar que o meio ambiente é tudo aquilo que cerca um organismo ( o homem é o organismo vivo), seja físico (água, ar, terra, bens tangíveis pelo homem), seja o social (valores culturais, hábitos, costumes, crenças), seja o psíquico (sentimento do homem e suas expectativas, segurança, angústia, estabilidade) uma vez que os meios físicos, social, e psíquico são os que dão as condições interdependentes, necessárias e suficientes para que o organismo vivo (planta ou animal) se desenvolva na sua plenitude 226 .
\end{abstract}

Sendo assim, parece ser impossível discutir a relação entre saúde e meio ambiente do trabalho, atravessando as causas de adoecimento dos trabalhadores, sem considerá-los parte integrante do meio ambiente do trabalho, haja vista que não há elemento psíquico isolado do organismo vivo trabalhador.

Talvez seja por esse equívoco que muitas doenças não são reconhecidas pela Previdência Social como relacionadas ao trabalho, sobretudo doenças psicológicas (estresse, depressão, síndrome do pânico, síndrome do esgotamento, etc.), ainda que diversos estudos no campo da saúde do trabalhador atestem a conexão com as condições (físicas e organizacionais) em que a atividade é desempenhada. O despreparo dos profissionais da saúde e peritos, a falta de apoio propedêutico, a desinformação dos trabalhadores sobre os riscos da atividade e as lacunas existentes no conhecimento médico-científico ${ }^{227}$ são outros fatores que podem dificultar o reconhecimento da conexão de determinadas doenças com o trabalho, cujo liame, direto ou indireto, nem sempre é buscado em perícias judiciais e previdenciárias rasas e mal feitas.

Portanto, consoante ao Princípio da Bidirecionalidade, os fatores pessoais do trabalhador interagem com os fatores ambientais do meio ambiente do trabalho, resultando em uma interação recíproca, um sendo modificado pelo outro. Por isso, a noção de meio ambiente do trabalho, à luz desse princípio, deve considerar o trabalhador como parte constitutiva e inseparável do locus laboral, bem como fizeram alguns dos participantes deste estudo, quando questionados quais aspectos compõem esse meio.

\footnotetext{
${ }^{226}$ PADILHA, Norma Sueli. Do Meio Ambiente do Trabalho Equilibrado. São Paulo: LTR, 2002. p. 27.

227 DIAS, Elizabeth Costa. Aspectos atuais da saúde do trabalhador no Brasil. In: ROCHA, Lys Esther; BUSCHINELLI, Tarcísio Penteado; RIGOTTO, Raquel Maria (Orgs.). Isto é trabalho de gente? Vida, doença e trabalho no Brasil. Petrópolis: Vozes, 1993.
} 
Por sua vez, o Princípio da Interdependência pressupõe a existência de uma interação entre as diversas dimensões ambientais (natural, artificial, cultural e do trabalho) e dos fatores inerentes a cada uma delas (sociais, econômicos, políticos, jurídicos, etc.), que dialogam entre si e influenciam tanto no meio ambiente do trabalho como na maneira em que o trabalhador enxerga, experimenta, negocia e dialoga com o meio em que ele se ativa.

Significa dizer que o trabalhador é influenciado tanto por aspectos de outras dimensões ou contextos ambientais, nas quais também se encontra ou não, como por fatores macrossistêmicos, mediatos e mais distais (sociais, econômicos, políticos, jurídicos, etc.), que embora não sejam atributos imediatos do meio ambiente do trabalho, influenciam no seu equilíbrio, pois refletem na organização da atividade e nas políticas públicas que afetam o campo do trabalho.

Como exemplo, a pesquisa de mestrado deste autor analisou a influência de uma sala de descanso implementada em uma empresa de telemarketing na saúde e na qualidade de vida dos trabalhadores. Os resultados obtidos apontaram o não uso daquela sala de descanso, embora os teleoperadores a considerassem benéfica para a saúde, por diversos fatores ambientais e pessoais, quais sejam: a distância entre a sala de descanso e o posto de atendimento (fator ambiental - aspecto arquitetural), o pouco tempo de intervalo (fator organizacional e jurídico), a forte cobrança de metas de número de chamadas atendidas e do tempo médio de atendimento (fator ambiental - organização do trabalho; fator pessoal aspecto psicológico), o precário incentivo ao uso da sala de descanso (fator pessoal - aspecto comportamental) e o temor de demissão pelo comprometimento da produtividade (fator pessoal - aspecto psicológico). Outra justificativa apontada foi a impossibilidade de se utilizar da sala de descanso pelo fato dos participantes estudarem após o final do expediente ou se ativarem em outro emprego, o que sinaliza a busca por melhores oportunidades de trabalho e remuneração (fator ambiental - aspectos macrossistêmicos, social e econômico) ${ }^{228}$.

Vale destacar que o Sindicato participante deste estudo definiu meio ambiente do trabalho sob a perspectiva do Princípio da Interdependência, conforme se observa no recorte colacionado a seguir:

\footnotetext{
${ }^{228}$ ALMEIDA, Victor Hugo de. Sala de descanso em empresas de telemarketing e qualidade de vida. 2008. 143 f. Dissertação (Mestrado em Psicologia) - Faculdade de Filosofia, Ciências e Letras de Ribeirão Preto, Universidade de São Paulo, São Paulo, 2008.
} 
Meio ambiente do trabalho é o local onde a pessoa trabalha. Mas eu vou um pouquinho mais longe. $\mathrm{E}$ acho que o meio ambiente envolve todo o meio ambiente, não só o local onde a pessoa trabalha. São as ruas, o ar condicionado, o equipamento utilizado, a forma de atendimento, as pessoas com que as pessoas tem que trabalhar, a forma mais fácil no atendimento, $o$ que pode gerar um melhor atendimento, o trabalho sendo feito de uma maneira alegre, de uma maneira tranquila, a tendência é fazer um trabalho melhor do que se ele trabalhar sob uma pressão, ou num local muito ruim, com pouca luminosidade... muito quente ou muito frio, tudo isso gera um ambiente de trabalho desagradável. Agora, de uma outra forma, você tem outras coisas que podem tornar esse ambiente desagradável... a pressão, as pessoas que trabalham junto, você não poder se relacionar com a pessoa do lado, não poder conversar, você acaba ficando isolado. No nosso caso de atendimento, você acaba ficando isolado, e isso leva muitas vezes a pessoa a se isolar um pouco do mundo e esquece que o ambiente de trabalho dele é aquele cubículo que ele está. Não é! É tudo mais, o restante todo da empresa, a pessoa que tá trabalhando do lado dele, iluminação, o ar, o rua onde ele trabalho, ruídos, conversas e uma descontração para que ele possa ter um tempo, pelos menos por alguns minutos, de aliviar a cabeça, pensar em outras coisas, poder ligar e falar com a esposas, com os filhos... ter alguns minutos para que ele possa relaxar um pouco, ter essa situação. (Participante: Sindicato).

Ao serem questionados quais os sistemas componentes do macrossistema (social, jurídico, econômico, político e cultural) que influenciam no meio ambiente do trabalho, todos os participantes apontaram o sistema jurídico e o sistema econômico. Apenas um não apontou o sistema social e outro, o sistema político. Todos os participantes apontaram que o sistema cultural não influencia no meio ambiente do trabalho.

A intervenção estatal por meio da regulamentação das relações de trabalho e da solução de conflitos apresentados à Justiça do Trabalho evidencia a influência do sistema jurídico no meio ambiente do trabalho, seja na seara preventiva, por meio das normas de saúde e segurança, seja na seara reativa, através da fiscalização e do exercício da jurisdição.

A velha batalha entre capital e trabalho evidencia a influência do sistema econômico nas relações laborais, nela compreendida a inter-relação trabalhador e meio ambiente do trabalho. A economia, o consumo, as políticas e crises econômicas nacionais e internacionais influenciam na dinâmica das contratações, do desemprego, na informalidade dos contratos e, inclusive, em alguns setores, na organização e nas condições de trabalho, impactando nas metas impostas aos trabalhadores, no ritmo da atividade, na dilação da jornada de trabalho e em outros diversos aspectos, como bem elucidou um dos participantes deste estudo, que vislumbrou essa interdependência na situação em que: 
(...) um consumidor aceita pagar um pouco mais por um produto, que se sabe feito com normas de padrão internacional e podia pagar menos por um produto que utilizou de mão de obra escrava. Isso pra mim é um exemplo clássico. (Participante: MT1).

Até mesmo a Consolidação das Leis do Trabalho, em seu artigo 555, alínea c, considera essa interdependência ao prever a pena de cassação da carta de reconhecimento à entidade sindical que criar obstáculos à execução da política econômica adotada pelo Estado; e ao prever, no artigo 623, a nulidade de pleno direito a disposição de negociação coletiva que, direta ou indiretamente, contrariar proibição ou norma disciplinadora da política econômico-financeira ou concernente à política salarial vigente. E mais, prevê o artigo celetista 896-A que, em sede de Recurso de Revista, deve o Tribunal Superior do Trabalho examinar previamente se a causa oferece transcendência com relação aos reflexos gerais de natureza econômica, dentre outros.

Em suma, explica Sérgio Pinto Martins que o Direito do Trabalho interage com a economia, cujo objeto de estudo é a produção, distribuição e consumo de bens essenciais ou úteis, a partir do momento em que o Estado intervém no sistema produtivo, estabelecendo políticas que tem reflexos no nível de emprego (econômica, salarial, etc.), ensejam modificações na estrutura jurídica ${ }^{229}$ ou impactam nas condições de trabalho, repercutindo no meio ambiente laboral.

Quanto ao sistema político, embora não apontado unanimemente pelos participantes, sua influência no contexto laboral, nele compreendido o meio ambiente do trabalho, também ocorre. Recorrendo a um exemplo já mencionado, o artigo 896-A da Consolidação das Leis do Trabalho também prevê que, em sede de Recurso de Revista, deve o Tribunal Superior do Trabalho examinar se a causa oferece transcendência com relação aos reflexos gerais de natureza política. Ademais, por política deve-se entender a "arte e ciência da organização e administração de um Estado, uma sociedade, uma instituição etc." 230 e "o conjunto de fatos, processos, conceitos, instituições etc. que envolvem e regem a sociedade, o Estado e suas instituições, e o relacionamento entre eles" ${ }^{\text {"231 }}$, sendo que esses dois conceitos remetem à ideia da relação entre Estado e sociedade, que compreende a função social estatal, nela inclusa a garantia do trabalho digno e adequado. No sentido figurado, política é a

\footnotetext{
${ }^{229}$ MARTINS, Sergio Pinto. Direito do Trabalho. 28. ed. São Paulo: Atlas, 2012.

${ }^{230}$ CAUDAS, Aulete. Aulete Digital. Dicionário Contemporâneo da Língua Portuguesa. São Paulo: Lexicon, 2008. Disponível em: <http://aulete.uol.com.br/site.php?mdl=aulete_digital〉. Acesso em: 30 ago. 2012.

${ }^{231}$ Ibidem.
} 
"habilidade para negociar e harmonizar interesses diferentes"232, sendo essa a principal competência das entidades sindicais na negociação dos interesses da categoria perante o Estado e os atores laborais. Portanto, conforme relatou um dos participantes deste estudo, evidente a interdependência entre as relações de trabalho e o sistema político, "por ser o sistema de pressão, para sensibilizar o Congresso, sensibilizar as autoridades, para lançar luzes sobre alguma profissão esquecida" (Participante MT1).

Em relação ao sistema cultural, não apontado por nenhum participante, é preciso antes esclarecer o que é cultura. Na língua portuguesa, entende-se por cultura o "conjunto de costumes predominantes num grupo ou classe social"; e "tudo o que caracteriza uma sociedade qualquer, compreendendo sua linguagem, suas técnicas, artefatos, alimentos, costumes, mitos, padrões estéticos e éticos” ${ }^{233}$. Portanto, costume é um dos elementos que caracteriza um grupo, classe social ou sociedade.

Ora, se cultura abrange costume, que é uma das formas de integração do ordenamento jurídico, nos termos do art. $4^{\circ}$ do Decreto-Lei $n^{\circ} 4.657$, de 4 de setembro de 1942 (Lei de Introdução às Normas do Direito Brasileiro), pode-se inferir sua influência nas relações laborais, que ocorrem no plano concreto do meio ambiente do trabalho.

Exemplo disso é o art. $5^{\circ}$ da Lei $n^{\circ} 5.889$, de 8 de junho de 1973, que estatui normas reguladoras do trabalho rural e prevê a concessão do intervalo para repouso e alimentação observados os usos e costumes regionais. Um outro exemplo é identidade de classe existente em algumas localidades, como no contexto da categoria dos metalúrgicos de São Bernardo do Campo, que consiste em um aspecto cultural que reforça a efetividade da atividade sindical regional e da representação dos trabalhadores das empresas na busca por melhores condições de trabalho, o que não se confere em todas as regiões do país. Essa cultura sindical favorece, por exemplo, a manutenção do equilíbrio do meio ambiente do trabalho através do importante papel da comissão de fábrica retratada na Convenção n ${ }^{\circ} 138$ da OIT e consagrada no art. 11 da Constituição Federal de 1988, que pode contribuir consideravelmente para a redução de acidentes de trabalho, entre outros benefícios. Assim sendo, existe interdependência entre o sistema cultural e o meio ambiente do trabalho.

${ }^{232}$ CAUDAS, Aulete. Aulete Digital. Dicionário Contemporâneo da Língua Portuguesa. São Paulo: Lexicon, 2008. Disponível em: <http://aulete.uol.com.br/site.php?mdl=aulete_digital〉. Acesso em: 30 ago. 2012.

232 Ibidem.

${ }^{233}$ Ibidem. 
E, por fim, quanto ao sistema social, não apontado por apenas um participante, acredita-se que aspectos sociais influenciam nas relações de trabalho, podendo, inclusive, contribuir com sua precarização. Cabe trazer o recorte da fala de um dos participantes que, além de alcançar a compreensão dessa interdependência, ainda exemplifica como o sistema social pode influenciar em outros sistemas e todos eles na inter-relação pessoa-ambiente:

O sistema cultural está junto com a minha resposta do social, porque precisa que haja um discernimento, um esclarecimento. Uma população mais e mais escolarizada entenderá quem é o alvo, pois é muito comum na nossa sociedade a gente atirar no alvo errado. A gente aproveita para xingar o caixa bancário, a gente aproveita para xingar o ascensorista, porque $o$ sistema cultural é decisivo na missão do discernimento.

Noutro giro, pode-se evidenciar a influência das políticas sociais no meio ambiente do trabalho, como por exemplo a Política Nacional de Saúde do Trabalhador, que apresenta interface com as políticas econômicas, além de estar diretamente relacionada às políticas do trabalho, da Previdência Social e do meio ambiente, nele incluído o meio ambiente do trabalho, visando à promoção de condições dignas, seguras e saudáveis de trabalho ${ }^{234}$.

Não se quer dizer que todos esses sistemas (social, econômico, político, jurídico e cultural) influenciam necessariamente e de forma homogênea em todo e qualquer contexto laboral examinado, mesmo porque é possível que um prevaleça ao outro dependendo do fenômeno, da abordagem e das especificidades contextuais analisadas. Defende-se sim que esses contextos são interdependentes e repercutem de forma diferente nos microssistemas, que não são neutros porque integram esse macrossistema, influenciando-o e por ele sendo influenciado. Nesta abordagem, o microssistema meio ambiente do trabalho está imerso no macrossistema e, por isso, percebe as influências dos sistemas que o compõe.

Vê-se, portanto, que os dados colhidos nesta pesquisa apontam a interdependência de diversos fatores e aspetos mediatos e imediatos, presentes ou não diretamente no meio ambiente do trabalho, sinalizando a interdependência tanto de aspectos pessoais como de aspectos ambientais do contexto estudado (microssistema) como de outros contextos mais amplos que com ele interagem (macrossistema).

\footnotetext{
${ }^{234}$ MINISTÉRIO DA SAÚDE. Política Nacional de Saúde do(a) Trabalhador(a): Proposta para Consulta Pública. Brasília. In: Portal da Saúde, Brasília, jan. 2004. Disponível em: <http://portal.saude.gov.br/portal/ arquivos/pdf/proposta_pnst_st_2009.pdf>. Acesso em: 12 set. 2012.
} 
Quanto ao presente estudo, os dois princípios são essenciais para a compreensão do fenômeno abordado, haja vista que se busca analisar a influência de aspectos macrossistêmicos - especialmente derivados do contexto econômico-social consumerista - no meio ambiente do trabalho e na saúde do trabalhador.

Com base no Princípio da Interdependência, busca-se demonstrar a interdependência entre o contexto macrossistêmico consumerista e o microssistema meio ambiente do trabalho, sobretudo na sua dimensão socioeconômica. E, com base no Princípio da Bidirecionalidade, busca-se evidenciar os impactos desse contexto no meio ambiente do trabalho (organização, condições de trabalho, etc.) e na saúde do trabalhador, considerando a inter-relação pessoa-ambiente.

\subsection{Uma concepção moderna de saúde do trabalhador como condição de um meio ambiente do trabalho equilibrado}

A respeito da noção de meio ambiente do trabalho equilibrado, Rodolfo Camargo Mancuso salienta a necessidade de abrangência de todos os aspectos que envolvem e condicionam, direta ou indiretamente, o "habitat laboral", em equilíbrio com o ecossistema, para atender às necessidades de sobrevivência e desenvolvimento e garantir patamares mínimos para uma satisfatória qualidade de vida do trabalhador ${ }^{235}$.

Portanto, sob a perspectiva sistêmica (noção jurídica) e interdependente (noção da abordagem ecológica), o equilíbrio do meio ambiente do trabalho é dependente das condições de todo o seu entorno ${ }^{236}$, devendo-se considerar "todos os elementos, interrelações e condições que influenciam o trabalhador em sua saúde física e mental, comportamento e valores reunidos no locus do trabalho",237.

A concepção de equilíbrio do meio ambiente do trabalho está intrinsecamente relacionada à noção de saúde do trabalhador e transcende os parâmetros da prevenção e da precaução, cujo dever se encontra estabelecido no artigo $7^{\circ}$, inciso XXII, da Constituição

\footnotetext{
235 MANCUSO, Rodolfo Camargo. Ação civil pública trabalhista: análise de alguns pontos controvertidos. Revista de Processo, RT, São Paulo, v. 93, a. 24, 1996. p. 161.

${ }^{236}$ PADILHA, Norma Sueli. Do Meio Ambiente do Trabalho Equilibrado. São Paulo: LTR, 2002.

${ }^{237}$ ROCHA, Julio César de Sá da. Direito ambiental do trabalho. São Paulo: LTr, 2002, p. 127.
} 
Federal. Espraia-se para os caminhos da busca pela qualidade de vida, uma das dimensões do termo saúde.

Resta, portanto, compreender o que é saúde e suas várias dimensões (prevenção, precaução, qualidade de vida e bem-estar), até mesmo para que seja possível fazer uma leitura jurídica do que vem a ser um comportamento, um trabalhador e um meio ambiente do trabalho saudável. Compreender se um determinado contexto é saudável ou não, exige que se busque averiguar o que é saúde para os atores daquele contexto. Este é o primeiro passo para se desenvolver ações, intervenções, políticas públicas e leis que proponham mecanismos viáveis e efetivos para a promoção de saúde no trabalho. E, mais do que isso, para que seja possível de cobrá-los do Poder Público.

A Constituição da Organização Mundial da Saúde define saúde como "um estado de completo bem-estar físico, mental e social, e não apenas a ausência de doenças" ${ }^{\text {,238 }}$. Em outras épocas, entendia-se por saúde o silêncio dos órgãos, depois a ausência de doenças e, mais recentemente, esse conceito espraiou-se para o vasto campo do bem-estar e da qualidade de vida, havendo ainda quem inclua ao conceito outros elementos, como o bem-estar espiritual, prometendo o impossível, ou nas palavras de Homero Batista Mateus da Silva, "o paraíso na Terra" 239 .

Quanto mais amplo o conceito de saúde, menos possível e efetivo no plano concreto. Corre-se o risco de que nenhum trabalhador ou meio ambiente do trabalho alcance esse "estado de completo bem-estar físico, mental e social"240. Por isso, conforme José Antônio Ribeiro de Oliveira Silva, é mais adequado se falar em noção do que em conceito de saúde ${ }^{241}$, pois uma noção é mais plástica e admite a subjetividade e a idiossincrasia de cada contexto. Para se ter condições seguras de propor uma definição ou ao menos uma noção do que seja esse direito, aponta o jurista que o caminho é buscar um núcleo essencial do direito à

238 ORGANIZAÇÃO MUNDIAL DA SAÚDE. Constituición de La Organización Mundial de La Salud. Disponível em: <http://www.who.int/gb/bd/S/S_documents.htm>. Acesso em: 20 maio 2012.

${ }^{239}$ Expressão usada por Homero Batista Mateus da Silva em diversas comunicações orais sobre o tema saúde e segurança no trabalho, dentre elas no Curso de Temas Atuais de Direito do Trabalho, realizado pelo Departamento de Direito do Trabalho e da Seguridade Social da Faculdade de Direito da Universidade de São Paulo, em 24 nov. 2012.

240 ORGANIZAÇÃO MUNDIAL DA SAÚDE. Op. cit.

241 SILVA, José Antônio Ribeiro de Oliveira. A saúde do trabalhador como um direito humano: conteúdo essencial da dignidade humana. São Paulo: LTr, 2008. 
saúde, e não enfeixá-lo numa redoma juslegalista ${ }^{242}$. Esse núcleo essencial deve identificar o que é imprescindível à satisfação das necessidades básicas da pessoa humana ${ }^{243}$.

Por isso, a noção de saúde deve ser construída contextualmente, considerando quem são aqueles trabalhadores, a atividade que exercem, o meio ambiente do trabalho que integram e o que é saúde para aqueles sujeitos. É a partir dessa análise contextual que é possível fazer uma leitura do que é saúde para um grupo de trabalhadores, cuja noção pode contribuir tanto para a promoção e estímulo de práticas saudáveis no ambiente trabalho como para a instituição de medidas preventivas, visando ao afastamento dos riscos aos quais estão sujeitos aqueles trabalhadores.

Para o campo da saúde, prevenir "exige uma ação antecipada"244 e significa "preparar; chegar antes de; dispor de maneira que evite (dano, mal); impedir que se realize" 245 .

Na concepção jurídica principiológica, conforme já exposto, há diferenças entre prevenção e precaução. Segundo Paulo Affonso Leme Machado, quanto ao Princípio da Precaução, "previne-se porque se sabe quais as consequências de se iniciar determinado ato, prosseguir com ele ou suprimi-lo. O nexo causal é cientificamente comprovado, é certo, decorre muitas vezes até da lógica" ${ }^{246}$; quanto ao Princípio da Prevenção, evita-se porque "não se pode saber quais as consequências que determinado ato, ou empreendimento, ou aplicação científica, causará ao meio ambiente no espaço e/ou no tempo, quais os reflexos ou consequências. Há incerteza científica não dirimida" 247 .

Para um completo estado de saúde, não basta apenas evitar a prática de determinados atos, cujas consequências nefastas são conhecidas pela ciência ou pela lógica, havendo ainda que se evitar ações, práticas e manipulação de substâncias, cujas consequências ainda são desconhecidas ou não comprovadas cientificamente. Logo, tanto a prevenção como a precaução são essenciais para um completo estado de saúde, porém, não bastam.

\footnotetext{
242 SILVA, José Antônio Ribeiro de Oliveira. A saúde do trabalhador como um direito humano: conteúdo essencial da dignidade humana. São Paulo: LTr, 2008.

243 Ibidem.

${ }^{244}$ LEAVELL, Hugh; CLARCK, Edwin Gurney. Medicina Preventiva. São Paulo: McGraw-Hill, 1976. p. 17.

${ }^{245}$ FERREIRA, Aurélio Buarque de Hollanda. Dicionário da Língua Portuguesa. 11. ed. Rio de Janeiro: Editora Civilização Brasileira, 1987.

${ }^{246}$ MACHADO, Paulo Affonso Leme. Critérios para Diferenciação dos Princípios da Prevenção. Ecoambiental. Disponível em: <http://www.ecoambiental.com.br/principal/principios.html>. Acesso em: 8 jun. 2011.

${ }^{247}$ Ibidem.
} 
O bem-estar da pessoa também se relaciona ao incremento do estado de saúde ${ }^{248}$, independentemente da existência de riscos ou perigos, comprovados cientificamente ou não, embora não devam ser desconsiderados. Juan Francisco Godoy ${ }^{249}$ esclarece que a promoção de saúde requer o conjunto de atuações centradas no indivíduo, grupos e na comunidade voltadas para a proteção, manutenção e melhoria da saúde. Wilfredo Guibert Reyes, Jorge Grau Abalo e Mariela de la Caridad Prendes Labrada ${ }^{250}$ associam a promoção de saúde à educação e esclarecem que promover saúde é educar, fazer com que as pessoas se apropriem de um comportamento realmente efetivo para um bom estado de saúde, através de novas práticas e da mudança de hábitos. Isso, evidentemente, exige que se conheça o contexto e o entendimento de saúde para aqueles nele se encontram.

A qualidade de vida é outro elemento do estado de saúde, cuja compreensão é necessária diante da menção desse termo em diversos dispositivos legislativos pátrios.

À guisa de exemplo, a Constituição da República Federativa do Brasil de 1988, ao instituir o meio ambiente ecologicamente equilibrado como um direito fundamental, dispõe em seu art. 225, parágrafo $1^{\circ}$, inciso V, o dever do Poder Público de "controlar a produção, a comercialização e o emprego de técnicas, métodos e substâncias que comportem risco para a vida, a qualidade de vida e o meio ambiente". Em seu art. 79, incluído pela Emenda Constitucional $n^{\circ} 31$ de 2010, a Constituição Federal torna a mencionar o termo qualidade de vida instituir no âmbito do Poder Executivo Federal o Fundo de Combate e Erradicação da Pobreza, "com o objetivo de viabilizar a todos os brasileiros acesso a níveis dignos de subsistência, cujos recursos serão aplicados em ações suplementares de nutrição, habitação, educação, saúde, reforço de renda familiar e outros programas de relevante interesse social voltados para melhoria da qualidade de vida".

A Constituição do Estado de São Paulo também faz menção ao termo qualidade de vida em diversos dispositivos. No art. 152, inciso I, institui como objetivo da organização regional do estado a promoção do "planejamento regional para o desenvolvimento sócioeconômico e melhoria da qualidade de vida". Também no art. 180, inciso V, institui o dever dos municípios assegurarem "a observância das normas urbanísticas, de segurança, higiene e

\footnotetext{
${ }^{248}$ LEAVELL, Hugh; CLARCK, Edwin Gurney. Medicina Preventiva. São Paulo: McGraw-Hill, 1976.

${ }^{249}$ GODOY, Juan Francisco. Psicología de la salud: delimitación conceptual. In: SIMON, M. A. (Ed.). Manual de psicología de la salud. Fundamentos, metodología y aplicaciones. Madrid: Editorial biblioteca Nueva, 1999.

250 GUIBERT REYES, Wilfredo; GRAU ÁBALO, Jorge; PRENDES LABRADA, Mariela de la Caridad. ¿Cómo hacer más efectiva la educación en salud en la atención primaria? Revista Cubana Medicina General y Integral, Ciudad de La Habana, v. 15, n. 2, p. 176-183, 1999. p. 182.
} 
qualidade de vida" e, no art. 183, inciso XI, a criação de um sistema de administração e qualidade ambiental, proteção, controle do desenvolvimento do meio ambiente e uso adequado dos recursos naturais, com a participação de órgãos de entidades da administração pública direta e indireta e da coletividade, visando "controlar e fiscalizar a produção, armazenamento, transporte, comercialização, utilização e destino final de substâncias, bem como o uso de técnicas, métodos e instalações que comportem risco efetivo ou potencial para a qualidade de vida e meio ambiente, incluindo o de trabalho". À luz do art. 79 da Constituição Federal, incluído pela Emenda Constitucional n ${ }^{\circ}$ 31/2010, a Constituição do Estado de São Paulo também previu a instituição Fundo de Combate e Erradicação da Pobreza no âmbito do Poder Executivo Estadual, com o fim de "proporcionar aos residentes no Estado de São Paulo o acesso a níveis dignos de sobrevivência, cujos recursos serão aplicados em ações complementares de nutrição, habitação, educação, saúde, reforço de renda familiar e outros programas de relevante interesse social voltados para a melhoria da qualidade de vida".

Na Lei ${ }^{\circ} 6.938$ de 31 de agosto de 1981, que dispõe sobre a Política Nacional do Meio Ambiente, há também menção ao termo qualidade de vida atrelado ao equilíbrio do meio ambiente, como objetivos das políticas públicas e normas deliberadas pelo Conselho Nacional do Meio Ambiente (CONAMA), órgão do Sistema Nacional do Meio Ambiente (SISNAMA), nos termos do art. $6^{\circ}$, inciso II, a seguir transcrito:

Art. $6^{\circ}$. Os órgãos e entidades da União, dos Estados, do Distrito Federal, dos Territórios e dos Municípios, bem como as fundações instituídas pelo Poder Público, responsáveis pela proteção e melhoria da qualidade ambiental, constituirão o Sistema Nacional do Meio Ambiente - SISNAMA, assim estruturado:

(...)

II - órgão consultivo e deliberativo: o Conselho Nacional do Meio Ambiente (CONAMA), com a finalidade de assessorar, estudar e propor ao Conselho de Governo, diretrizes de políticas governamentais para o meio ambiente e os recursos naturais e deliberar, no âmbito de sua competência, sobre normas e padrões compatíveis com o meio ambiente ecologicamente equilibrado e essencial à sadia qualidade de vida - grifo nosso.

Contudo, o que se deve entender por qualidade de vida? De acordo com Augus Campbel, qualidade de vida é "uma vaga e etérea entidade, algo sobre a qual muita gente fala, 
mas que ninguém sabe claramente o que é" ${ }^{, 251}$. Essa ideia de abstração do termo talvez se justifique porque a noção de qualidade de vida ainda está em construção e, evidentemente, deve ser flexível e dinâmica ao ponto de ser adaptada às necessidades de cada contexto, tempo e realidade.

Nesse sentido, para Eliane Maria Fleury Seidl e Célia Maria Lana da Costa Zannon, o conceito de qualidade de vida deve considerar dois aspectos: subjetividade e multidimensionalidade. Subjetividade, porque qualidade de vida para uma pessoa ou um grupo não necessariamente será qualidade de vida para outros indivíduos ou para toda coletividade e, multidimensionalidade, por se tratar de um construto eminentemente interdisciplinar e que deve considerar a interdependência de vários contextos e aspectos interligados, pessoais e ambientais em sentido amplo. Diante dessa complexidade, salientam as autoras a necessidade da integração de diferentes áreas do conhecimento, que podem "contribuir para a melhoria da qualidade e da integralidade da assistência na perspectiva da saúde como direito e cidadania" ${ }^{252}$.

Com base na Convenção $n^{\circ} 155$ da Organização Internacional do Trabalho sobre o tema Saúde e Segurança dos Trabalhadores, aprovada no Brasil pelo Decreto Legislativo $\mathrm{n}^{\mathbf{0}} 2$ de 17 de março de 1992 e ratificada em 18 de maio do mesmo ano, José Afonso da Silva vincula qualidade de vida com qualidade do meio ambiente do trabalho, como modalidade de direito fundamental da pessoa humana ${ }^{253}$. Portanto, nessa perspectiva, a qualidade de vida depende também da qualidade do meio ambiente do trabalho.

Concordamos que a efetiva promoção de qualidade de vida é indissociável da noção de saúde e de meio ambiente equilibrado, nele incluído o meio ambiente do trabalho sob a perspectiva sistêmica e interdependente já examinada anteriormente, pois "o mundo é um só e os trabalhadores existem, neste mundo, transformado e sendo transformados por

\footnotetext{
${ }^{251}$ AWAD, George; VORUGANTI, Lakshmy Narayana Pant. Intervention research in psychosis: issues related to the assessment of quality of life. Schizophrenia Bulletin. Disponível em: <http://schizophreniabulletin. oxfordjournals.org/content/26/3/557.full.pdf+html>. Acesso em: 8 jun. 2011.

${ }^{252}$ SEIDL, Eliane Maria Fleury; ZANNON, Célia Maria Lana da Costa. Qualidade de vida e saúde: aspectos conceituais e metodológicos. Caderno Saúde Pública, Rio de Janeiro, n. 20, v. 2, p. 580-588, 2004. p. 587.

${ }^{253}$ SILVA, José Afonso da. Curso de direito constitucional positivo. 22. ed. rev. atual. São Paulo: Malheiros, 2003.
} 
ele ${ }^{, 254}$. Daí também a noção da inter-relação pessoa-ambiente disposto no Princípio da Bidirecionalidade proposto e construído neste estudo.

Se promover saúde é atuar em suas mais diversas dimensões e não apenas na busca pela ausência de doenças, parece adequado afirmar que a promoção de saúde não se limita apenas à prevenção e à precaução, mas espraia-se também para o campo da promoção de qualidade de vida e bem-estar na busca de um meio ambiente equilibrado, incluindo o do trabalho.

O dever de promoção de saúde está atrelado aos direitos fundamentais à vida, à dignidade da pessoa humana e ao trabalho digno, que "denotam não somente a preocupação com a ausência de doenças, mas também com a busca do completo bem-estar físico, mental e social do indivíduo em sua comunidade" 255 .

Há também que se considerar que é dever do empregador promover qualidade de vida e bem-estar no meio ambiente do trabalho, cujas condições influenciam e são influenciadas pelo ambiente geral, resultando ou não no seu equilíbrio, pois, conforme Sebastião Geraldo Oliveira, "é impossível alcançar qualidade de vida sem ter qualidade de trabalho, nem se pode atingir meio ambiente equilibrado e sustentável, ignorando o meio ambiente do trabalho",256.

Promover saúde, na perspectiva da qualidade de vida, é educar, informar e estimular a apropriação pelas pessoas de práticas, comportamentos e relações saudáveis, mesmo na esfera laboral. Sendo assim, se for admitido que apenas é dever do empregador a prevenção e a precaução quanto aos riscos inerentes à atividade, estar-se-ia afastando também o dever patronal de manter um meio ambiente do trabalho equilibrado por meio de práticas, ações, informações, políticas internas e relacionamento interpessoal sadio que, evidentemente, influenciam no bem-estar daqueles que dele fazem parte.

\footnotetext{
254 DIAS, Elizabeth Costa. Aspectos atuais da saúde do trabalhador no Brasil. In: ROCHA, Lys Esther; BUSCHINELLI, Tarcísio José; RIGOTTO, Raquel Maria. (Orgs.). Isto é trabalho de gente? Vida, doença e trabalho no Brasil. Petrópolis: Vozes, 1993. p. 139.

${ }^{255}$ SILVA, Otavio Pinto e. Meio ambiente e saúde do trabalhador. Revista do TRT da $2^{a}$ região, São Paulo, n. 4/2010, p. 69-119. p. 69

${ }^{256}$ OLIVEIRA, Sebastião Geraldo. Proteção jurídica à saúde do trabalhador. 4. ed. São Paulo: LTr, 2002. p. 129.
} 
Evidenciando essa relação entre saúde e meio ambiente, Daniel Stokols elenca algumas funções do ambiente sócio-físico relacionadas à promoção de saúde, esclarecendo que o ambiente pode operar, positiva ou negativamente, como:

- transmissor de doenças (por exemplo, como meio de propagação de doenças contagiosas);

- estressor (por exemplo, submetendo pessoas a ruídos acima do nível de tolerância, a conflitos interpessoais, a ritmos e condições de trabalho exaustivas, etc.);

- fonte de segurança ou de eliminação de riscos e perigos (por exemplo, eliminando ou reduzindo riscos inerentes a atividade, desastres tecnológicos e naturais, etc.);

- fonte de estímulo a comportamentos saudáveis (por exemplo, estimulando práticas que proporcionem bem-estar, através da informação e educação, etc.);

- contexto de promoção de saúde (por exemplo, implementando serviços de saúde comunitária, zelando pela qualidade do ambiente físico e natural através do cumprimento da legislação, etc.) ${ }^{257}$.

Cabe, portanto, examinar quais os fatores do ambiente sócio-físico que podem influenciar na saúde do trabalhador

\subsection{Fatores e aspectos que compõem o meio ambiente do trabalho: uma sistematização necessária}

Quanto ao meio ambiente geral, Daniel Stokols ${ }^{258}$ aponta a influência de fatores pessoais, incluindo aspectos biogenéticos, comportamentais e psicológicos; e de fatores ambientais, incluindo aspectos geográficos, arquiteturais-tecnológicos e socioculturais.

\footnotetext{
${ }^{257}$ STOKOLS, Daniel. Establishing and maintaining healthy environments. American Psychologist, Washington, v. 47, n. 1, p. 6-22, 1992.

${ }^{258}$ Ibidem.
} 
Propomos uma releitura dessa sistematização apresentada por Daniel Stokols ${ }^{259}$, focalizando especificamente o meio ambiente do trabalho, por meio do seguinte constructo:

\section{Fatores pessoais:}

(a) aspectos biogenéticos (por exemplo, sexo, idade cronológica, histórico de doenças na família, competência imunológica, deficiência, etc.);

(b) aspectos comportamentais (por exemplo, participação em programas de promoção de saúde, padrões de sono, tabagismo, consumo de álcool/drogas, etc.); e

(c) aspectos psicológicos (por exemplo, otimismo, criatividade, extroversão, habilidade interpessoal, ansiedade, estado depressivo, esgotamento, estresse, pressão, satisfação com o trabalho, subjetividade, etc.).

\section{Fatores ambientais:}

(a) aspectos geográficos (por exemplo, clima, vegetação, radiação ultravioleta, aquecimento global, ruído, insalubridade, periculosidade, etc.);

(b) aspectos arquiteturais-tecnológicos (por exemplo, arquitetura, ergonomia, estrutura das áreas de trabalho, arranjo espacial, radiação eletromagnética, poluição sonora, poluição ambiental, aparatos tecnológicos, equipamentos, maquinários, etc.); e

(c) aspectos socioculturais (por exemplo, status socioeconômico individual e coletivo, crenças e práticas culturais e religiosas, clima social na empresa, instabilidade política, mudanças econômicas, legislação - existência, aplicação e eficácia, etc.).

${ }^{259}$ STOKOLS, Daniel. Establishing and maintaining healthy environments. American Psychologist, Washington, v. 47, n. 1, p. 6-22, 1992. 
Propomos, ainda, a inclusão de aspectos organizacionais (por exemplo, rotina, procedimentos, regulamento da empresa, normas coletivas, estrutura hierárquica, penosidade, jornada de trabalho, intervalos, pausas, etc.) aos fatores ambientais, diante da certeza de que esses aspectos, que devem ser considerados parte do meio ambiente do trabalho, exercem incontestável influência na saúde dos trabalhadores. Acredita-se, inclusive, que esses aspectos são estreitamente inter-relacionados com os aspectos pessoais, pois influenciam na satisfação individual e coletiva dos trabalhadores com o trabalho e nas relações interpessoais.

A pesquisa de mestrado deste autor, que buscou averiguar o uso de uma sala de descanso como medida de redução de afastamentos por motivo de saúde no contexto de telemarketing, evidenciou essa inter-relação entre os aspectos organizacionais e pessoais do contexto investigado. Dos 80 teleoperadores participantes, $26 \%$ apontou a necessidade de revisão dos aspectos organizacionais (por exemplo, atividades menos repetitivas, sistema diferenciado de atendimento, jornada reduzida, maior autonomia no trabalho, rodízio de campanhas, maior tempo entre ligações, melhor remuneração, etc.) como medida de redução de afastamento por motivos de saúde, sobretudo em caso de estresse e depressão.

Diversas pesquisas, sobretudo no campo da saúde, também evidenciam a influência dos aspectos organizacionais no processo de adoecimento e promoção de saúde do trabalhador.

A pesquisa realizada por Silvia Helena Henriques Camelo et al. apontou que os riscos ergonômicos aos quais estão expostos os profissionais da saúde estão relacionados à organização do trabalho, como por exemplo, ritmo acelerado, aumento da jornada e número reduzido de trabalhadores. Salienta o estudo que as formas de organização e gestão do trabalho tem contribuído para o adoecimento dos trabalhadores em serviços de saúde, embora haja mais estudos e práticas dedicados ao diagnóstico e gerenciamento de riscos ocupacionais do que a mudanças organizacionais e ações de promoção de saúde ${ }^{260}$.

Outro estudo sobre formas de adoecimento pelo trabalho e estratégias de gerenciamento vincula o processo de adoecimento dos trabalhadores às múltiplas tarefas

\footnotetext{
${ }^{260}$ CAMELO, Silvia Helena Henriques, et al. Adoecimento e promoção da saúde do trabalhador. In: VIII Seminário de Saúde do trabalhador e VI Seminário O trabalho em debate, 2012, Franca. Anais do VIII Seminário de Saúde do trabalhador e VI Seminário "O Trabalho em debate", 2012.
} 
delegadas, ao alto grau de exigência e responsabilidade, ao ambiente e à organização do trabalho $^{261}$.

Portanto, essa sistematização dos fatores e aspectos que integram o meio ambiente do trabalho e podem influenciar na saúde do trabalhador pode ser melhor representada pelo organograma a seguir exposto:

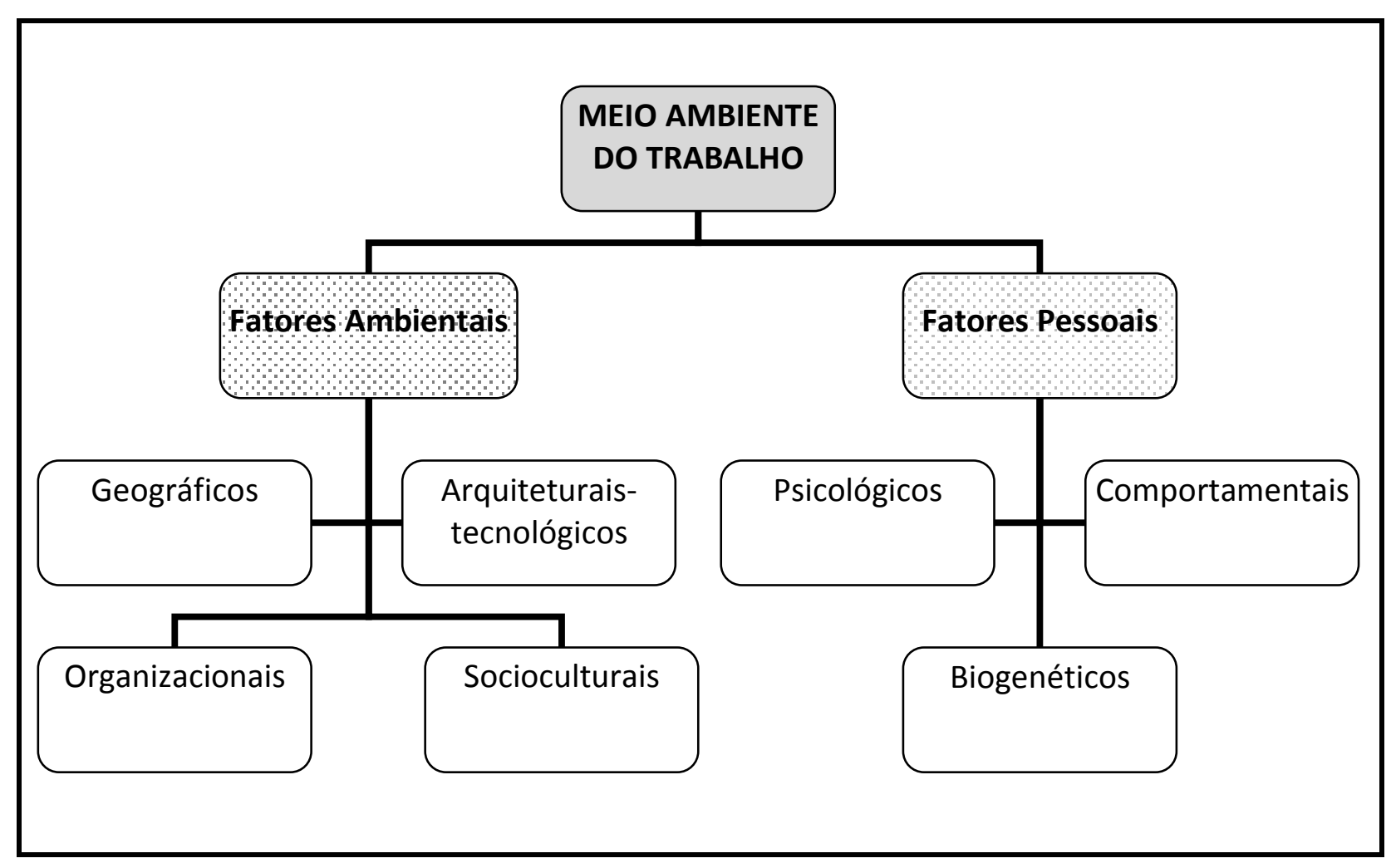

Figura 2. Sistematização dos fatores e aspectos componentes do meio ambiente do trabalho.

Evidentemente que não são apenas esses aspectos que explicam o estado de saúde em um contexto laboral específico, pois, conforme já discorrido, os aspectos de um determinado microssistema laboral também são influenciados por aspectos macrossistêmicos (econômicos, sociais, culturais, jurídicos e políticos), que moldam a organização do trabalho para a obtenção de certos resultados e influenciam na maneira como os trabalhadores experienciam, dialogam e negociam com o meio ambiente do trabalho.

${ }^{261}$ CAMELO, Silvia Helena Henriques, et al. Adoecimento e promoção da saúde do trabalhador. In: VIII Seminário de Saúde do trabalhador e VI Seminário O trabalho em debate, 2012, Franca. Anais do VIII Seminário de Saúde do trabalhador e VI Seminário "O Trabalho em debate", 2012. 
De acordo com a Figura 3, a seguir apresentada, os sistemas econômico, cultural, político, jurídico e social integram o contexto denominado macrossistema:

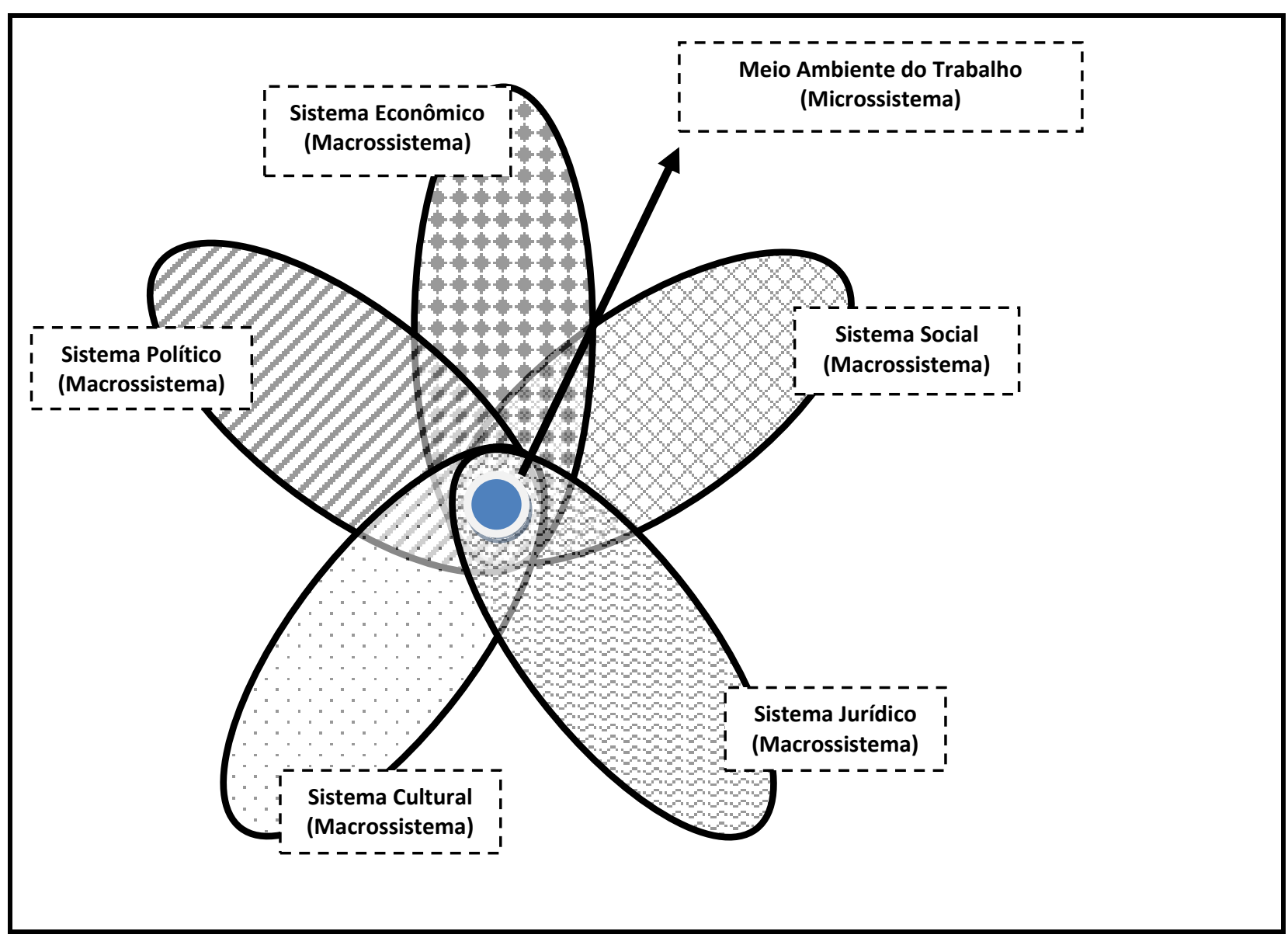

Figura 3. Sistemas que integram o macrossistema: interdependência com o meio ambiente do trabalho.

Cada um desses sistemas exerce influência nos outros e todos influenciam os microssistemas que neles se encontram imersos; alguns mais, outro menos. Sob a perspectiva da presente abordagem, esses sistemas se influenciam e, por sua vez, influenciam no microssistema meio ambiente do trabalho, podendo contribuir positiva ou negativamente para o seu equilíbrio. Assim sendo, sob a perspectiva do Princípio da Interdependência, eventual desarmonia entre esses sistemas pode comprometer o equilíbrio do meio ambiente do trabalho e impactar na saúde do trabalhador.

Tome-se como exemplo o enfrentamento de uma crise econômica (sistema econômico) sem qualquer política pública que busque estancar o crescimento de elevado índice de desemprego (sistema social). Estima-se, por exemplo, que um dos reflexos desse desequilíbrio seria a instabilidade e a pressão suportada pelos empregados dos setores mais atingidos pela crise (fator pessoal - aspecto psicológico do meio ambiente do trabalho) e o 
enrijecimento da organização do trabalho (fator ambiental - aspecto organizacional do meio ambiente do trabalho).

Outro exemplo é a instituição de um regramento que torne obrigatório o atendimento médico antes do uso de todo e qualquer medicamento (aspecto jurídico), com a finalidade de modificar a cultura de automedicação (sistema cultural). Se nesse caso não houver uma ampliação das unidades de saúde com número satisfatório de profissionais, ter-seá um aumento considerável e imediato da demanda, que muito poderia contribuir para o adoecimento e afastamento dos trabalhadores da atividade e, consequentemente, para a insatisfação dos usuários do sistema de saúde, pela insuficiência de médicos, enfermeiros e técnicos na rede de atendimento (sistema social).

Esse conflito pode ser intersistêmico, ou seja, entre elementos que integram sistemas diversos, ou intrassistêmico, entre elementos de um mesmo sistema. As situações expostas nos parágrafos acima constituem conflitos intersistêmicos. Um exemplo de conflito intrassistêmico seria a instituição de duas legislações antagônicas voltadas para o mesmo contexto (sistema jurídico). É o caso da regulamentação do atendimento por meio de telemarketing que limitou a sessenta segundos o tempo máximo de espera dos consumidores na linha e, um ano antes, o Ministério do Trabalho e Emprego já havia instituído o Anexo II da NR 17, proibindo a utilização de mecanismos para acelerar o ritmo da atividade de telemarketing. Esse exemplo de conflito intrassistêmico no plano do sistema jurídico será melhor analisado nos Capítulos 4 e 5 deste estudo.

Portanto, na perspectiva sistêmica e interdependente, tantos os fatores ambientais - do contexto imediato laboral (aspectos físicos - geográfico, arquitetural-tecnológico, sociocultural e organizacional) e de contextos mais amplos e distais (econômicos, sociais, jurídico e políticos) - como os fatores pessoais (aspectos psicológicos e comportamentais) influenciam na relação pessoa-ambiente e, por corolário, no equilíbrio do meio ambiente do trabalho e na saúde do trabalhador.

\subsection{A saúde do trabalhador como um direito fundamental}

Antes mesmo da promulgação da Constituição Federal de 1988, consolidou-se no país o movimento da Reforma Sanitária, assentado na saúde como um direito de todos. 
Considerando que é a sociedade a destinatária das ações de saúde, a usuária das instituições e a melhor conhecedora das deficiências da prestação, esse movimento pautou-se na participação social, e não apenas do Estado, para a efetivação do direito fundamental à saúde.

A legitimidade das reivindicações desse movimento, que empenhou as bandeiras da universalização e da concretização, elevou a saúde ao patamar de direito fundamental insculpido na Constituição Federal de 1998, prevendo em seu artigo 196 que "a saúde é direito de todos e dever do Estado, garantido mediante políticas sociais e econômicas que visem à redução do risco de doença e de outros agravos e ao acesso universal e igualitário às ações e serviços para sua promoção, proteção e recuperação".

Ao mesmo passo que nascia um direito fundamental, surgia também o desafio de como dar capilaridade a esse direito e concretizá-lo de forma efetiva e democrática, porque, à luz da lição de Norberto Bobbio, o importante não é justificar os direitos fundamentais, mas protegê-los e buscar meios eficazes para implementá-los, não bastando apenas proclamá$\operatorname{los}^{262}$.

O Sistema Único de Saúde (SUS), instituído e regulamentado pela Lei Orgânica da Saúde no 8.080/90, portanto dois anos após a promulgação da Constituição Federal vigente, foi a forma que o Poder Público encontrou para alcançar, ou ao menos buscar, a universalidade do direito à saúde, conforme explica Hésio Cordeiro:

Os princípios do novo sistema de saúde defendiam a descentralização e o fortalecimento do papel do município, participação e controle popular na formulação de políticas, planejamento, gestão, execução e avaliação das ações de saúde, integralização das ações, universalização do acesso e da cobertura, iniciados pelas áreas carentes ou totalmente desassistidas, e equidade e garantia de qualidade na humanização do atendimento ${ }^{263}$.

A proposta de um sistema único buscava a organização do setor público federal, estadual e municipal, incluindo os serviços privados conveniados, para uma gestão da rede de serviços de saúde pautada na descentralização e na universalidade, ou seja, a distribuição de unidades de saúde pelo território brasileiro para o atendimento de toda população.

Em seguida, com a Lei $n^{\circ} 8.142 / 90$, foram criados os Conselhos de Saúde e as Conferências de Saúde, como espaços públicos de participação da sociedade, convidando os

\footnotetext{
${ }^{262}$ BOBBIO, Norberto. A era dos direitos. 10. reimp. Rio de Janeiro: Elsevier, 2004.

${ }^{263}$ CORDEIRO, Hésio. Sistema Único de Saúde. Rio de Janeiro: Ayuri Editorial, 1991. p. 85.
} 
atores civis a também protagonizarem o processo de planejamento, promoção e fiscalização de políticas públicas, referendando o liame entre saúde, democracia e cidadania.

Quanto ao campo da saúde do trabalhador, antes da criação do Sistema Único de Saúde, assuntos relacionados à Política Nacional de Saúde no Trabalho, como redução de acidentes de trabalho e doenças ocupacionais, eram tratados no âmbito do Ministério do Trabalho e Emprego e da Previdência Social. O Sistema Único de Saúde reviu essa estrutura baseando-se em dois aspectos: a capilaridade - unidades de saúde em todos os municípios brasileiros - e a universalidade - atendimento de trabalhadores do serviço público e privado. Carlos Vaz, coordenador-geral do Ministério da Saúde, aponta que anualmente é repassado cerca de 72 milhões de reais aos duzentos Centros de Referência em Saúde do Trabalhador instalados em todos os estados brasileiros ${ }^{264}$.

A Política Nacional de Saúde no Trabalho (PNSST), nos termos do item I do anexo aprovado pelo Decreto $\mathrm{n}^{\mathrm{o}} 7.602$ de 7 de novembro de 2011, tem por objetivo a "promoção da saúde e a melhoria da qualidade de vida do trabalhador e a prevenção de acidentes e de danos à saúde advindos, relacionados ao trabalho ou que ocorram no curso dele, por meio da eliminação ou redução dos riscos nos ambientes de trabalho"; e é assentada nos seguintes princípios: universalidade; prevenção; precedência das ações de promoção, proteção e prevenção sobre as de assistência, reabilitação e reparação; diálogo social e integralidade.

O Decreto $n^{\circ}$ 7.602/2011 ainda instituiu como responsáveis pela implementação e execução da Política Nacional de Saúde no Trabalho os Ministérios do Trabalho e Emprego, da Saúde e da Previdência Social, sem prejuízo de outros órgãos ou instituições afins, fixando, em seu item IV, as seguintes diretrizes:

a) inclusão de todos trabalhadores brasileiros no sistema nacional de promoção e proteção da saúde;

b) harmonização da legislação e a articulação das ações de promoção, proteção, prevenção, assistência, reabilitação e reparação da saúde do trabalhador;

c) adoção de medidas especiais para atividades laborais de alto risco;

d) estruturação de rede integrada de informações em saúde do trabalhador;

${ }^{264}$ SAÚDE DO TRABALHADOR. A Voz do Brasil. Brasília: Rede Nacional, 24 de agosto de 2012. Programa de rádio. 
e) promoção da implantação de sistemas e programas de gestão da segurança e saúde nos locais de trabalho;

f) reestruturação da formação em saúde do trabalhador e em segurança no trabalho e o estímulo à capacitação e à educação continuada de trabalhadores; $\mathrm{e}$

g) promoção de agenda integrada de estudos e pesquisas em segurança e saúde no trabalho.

Previu ainda no item IV que, compete ao Ministério do Trabalho e Emprego, entre outras responsabilidades, "elaborar e revisar, em modelo tripartite, as Normas Regulamentadoras de Segurança e Saúde no Trabalho" (item VI, b); "promover estudos da legislação trabalhista e correlata, no âmbito de sua competência, propondo o seu aperfeiçoamento" (item VI, d); acompanhar o cumprimento, em âmbito nacional, dos acordos e convenções ratificados pelo Governo brasileiro junto a organismos internacionais, em especial à Organização Internacional do Trabalho - OIT, nos assuntos de sua área de competência (item VI, e); e, "por intermédio da Fundação Jorge Duprat Figueiredo de Segurança e Medicina do Trabalho - FUNDACENTRO”, entre outras tarefas, elaborar estudos e pesquisas sobre problemas que afetam a segurança e a saúde trabalhador, desenvolver e executar ações educativas e difundir informações para a proteção e promoção de saúde no trabalho (item VI, g, 1, 3 e 4).

Embora desde 2004 já constasse da Proposta para Consulta Pública da Política Nacional de Saúde do Trabalhador a articulação das estruturas organizadas da sociedade civil e das organizações de trabalhadores, para garantir a participação e dar subsídios para a promoção de condições de trabalho dignas, seguras e saudáveis para todos os trabalhadores ${ }^{265}$, a participação social dos atores não estatais em ações de saúde ainda é escrava de uma visão que a concebe como um favor prestado pelo Estado, uma caridade, e não como um direito a ser efetivado a partir da sua democratização e do exercício consciente da cidadania, que não se esgota no voto. Consiste, substancialmente, na diferença entre participar e ser representado.

Esclarece Felipe Dutra Asensi que democracia representativa "significa a participação da população nas decisões políticas por intermédio de representantes, os quais objetivam realizar a vontade geral dos representados de acordo com a lei e com a legitimidade

${ }^{265}$ MINISTÉRIO DA SAÚDE. Política Nacional de Saúde do(a) Trabalhador(a): Proposta para Consulta Pública. Brasília. In: Portal da Saúde, Brasília, jan. 2004. Disponível em: <http://portal.saude.gov.br/portal/ arquivos/pdf/proposta_pnst_st_2009.pdf>. Acesso em: 12 set. 2012. 
que lhes foi aferida pelo voto". E democracia participativa, "a participação da população em conjunto aos seus representantes em espaços públicos, com o objetivo de promover, formular, deliberar e fiscalizar as políticas públicas em igualdade de voz e voto, de modo a legitimar socialmente as decisões ali estabelecidas" 266 .

Se a democracia participativa pressupõe a participação da sociedade, com igualdade de voz e voto, essa finalidade democrática também deve permear tanto a produção como a interpretação do direito. Para Luiz Werneck Vianna e Marcelo Burgos, o que caracteriza a democracia participativa é a procedimentalização do direito, ou seja, a democracia no processo de produção do direito ${ }^{267}$.

Portanto, não há que se falar em efetivação do direito à saúde por meio de lei ou de políticas públicas sem a participação da sociedade, incluindo os atores não estatais, destinatários diretos dessas ações, tanto para impedir ingerências por parte do Estado como para o desenvolvimento de normas e políticas públicas que busquem efetivar plenamente esse direito (garantindo atendimento médico-hospitalar, materiais, medicamentos, equipamentos, saúde e segurança no trabalho, etc.).

Essa procedimentalização requer o diálogo entre todos os protagonistas no que diz respeito à finalidade e aos procedimentos de efetivação do direito à saúde que, para Luiz Werneck Vianna e Marcelo Burgos, possui “um caráter de direito individual (pois é pertencente a cada indivíduo), social (pois diz respeito à esfera pública) e de participação (pois pressupõe a participação popular); o conjunto destas três dimensões remete à ideia de saúde como um direito de cidadania" ${ }^{, 268}$.

No campo da saúde do trabalhador, a necessidade dessa participação ainda é mais evidente. Primeiro, porque a noção de saúde no trabalho deve ser plástica e contextual; deve atender a subjetividade e as necessidades da coletividade de trabalhadores de cada categoria profissional, atentando-se para as especificidades do meio ambiente do trabalho, sem negligenciar os aspectos pessoais e ambientais daquele contexto. A título de ilustração, o entendimento de saúde para um trabalhador em minas e subsolo certamente não será o mesmo

\footnotetext{
${ }^{266}$ ASENSI, Felipe Dutra. Biodireito, saúde e participação social. In: Âmbito Jurídico, Rio Grande, IX, n. 32, ago 2006. Disponível em: <http://www.ambito-juridico.com.br/site/?n_link=revista_artigos_leitura\&artigo_ id=1232\&revista_caderno=6>. Acesso em: 12 ago. 2012.

${ }^{267}$ VIANNA, Luiz Werneck; BURGOS, Marcelo. Revolução processual do direito e democracia progressiva. In: VIANNA, Luiz Werneck. Democracia e os três poderes no Brasil. Belo Horizonte: Editora UFMG, 2003.

${ }^{268}$ Ibidem.
} 
para um trabalhador em telemarketing, pois o equilíbrio do meio ambiente do trabalho em cada uma dessas atividades deverá levar em consideração o que é saúde na perspectiva de cada uma delas para a efetivação desse direito fundamental. Segundo, porque são os próprios trabalhadores que vivenciam aquele contexto e, por isso, ninguém melhor que eles conhece os riscos da atividade e as necessidades para se alcançar um meio ambiente do trabalho equilibrado, capaz de promover saúde aos trabalhadores que o integram.

Nesse prisma, encerra Sueli Dallari:

O direito à saúde, portanto, goza da mesma complexidade, onde fique evidente a necessidade de haver efetiva participação popular para que ele seja definido. Se saúde é assim complexa, é impossível que alguém possa defini-la, em última instância, numa mesa, num gabinete.

É necessário que o povo diga o que entende por saúde e, portanto, por direito à saúde.

(...)

Isso significa afirmar que as ações que compõem a política de saúde se traduzem em atos normativos - têm que se traduzir em atos normativos, porque vivemos em um Estado de Direito -, mas elas também exigem a participação popular, porque essa é a única forma de se garantir o direito justo. Vivemos em um Estado democrático - nosso Estado é democrático de Direito. ${ }^{269}$

Dito isto, para compreender se um determinado contexto no campo da saúde do trabalhador é saudável ou não, há que se averiguar o que é saúde para os protagonistas daquele contexto. Este é o primeiro passo para se desenvolver ações, intervenções, políticas públicas e normas que proponham mecanismos viáveis e efetivos para a promoção de saúde no trabalho. E, mais do que isso, para que seja possível fazer uma leitura jurídica da concepção de saúde para aqueles trabalhadores e cobrá-la do empregador, tomador e do Poder Público.

Por isso, Víctor Currea-Lugo destaca que uma definição do direito à saúde deve ser real ou potencialmente "garantizável” para que seja exigível ${ }^{270}$.

Não se deve esquecer que a saúde é um dos elementos viabilizadores do direito ao trabalho digno, também considerado um direito fundamental. Dentre os princípios gerais da atividade econômica, previstos no art. 170 da Constituição da República Federativa do Brasil

\footnotetext{
${ }^{269}$ DALLARI, Sueli Gandolfi. Comunicação - Centro de Estudos e Pesquisas de Direito Sanitário. Supremo Tribunal Federal, 6 maio 2009. Disponível em: <http://www.stf.jus.br/arquivo/cms/processoAudienciaPublica Saude/anexo/SUELI_DALLARI.pdf >. Acesso em: 8 out. 2012.

${ }_{270}$ CURREA-LUGO, Víctor de. La salud como derecho humano: 15 requisitos y uma mirada a lãs reformas. Bilbao: Cuadernos Deusto de Derechos Humanos, Universidade de Deusto, 2005, p. 29-30.
} 
de 1988, estão os princípios da Função Social da Propriedade, da Defesa do Meio Ambiente e da Busca do Pleno Emprego, que impingem caráter social à atividade econômica e possuem um importante papel na efetivação do direito ao trabalho.

O Princípio da Função Social da Propriedade, previsto tanto no art. 170, inciso III, como no art. $5^{\circ}$, inciso XXIII da Constituição Federal, possui função harmonizadora dos interesses econômicos e sociais, compreendidos nestes últimos os interesses trabalhistas. Deve portanto a propriedade atender a sua função social, sobretudo quando destinada a fins econômicos. Segundo Fábio Konder Comparato:

$\mathrm{O}$ adjetivo social mostra que esse objetivo corresponde ao interesse coletivo e não ao interesse próprio do dominus; o que não significa que não possa haver harmonização entre um e outro. Mas de qualquer modo, se se está diante de um interesse coletivo, essa função social da propriedade corresponde a um poder-dever do proprietário, sancionável pela ordem jurídica. $^{271}$

Há quem entenda que este postulado possui função limitadora da autonomia da propriedade privada sobre os bens. Contudo, não se trata de um limite ao direito de propriedade e à livre iniciativa, haja vista que a empresa gozará de autonomia e liberdade quando respeitar os direitos e garantias dos trabalhadores e consumidores, o meio ambiente (incluindo o do trabalho) e a livre concorrência. Nesse sentido, esclarece José Affonso da Silva:

A função social da propriedade não se confunde com os sistemas de limitação da propriedade, pois estes dizem respeito ao exercício do direito do proprietário. A função social da propriedade privada surge em razão da utilização produtiva dos bens de produção, proporcionando crescimento econômico e produção de riquezas na forma de um bem estar coletivo. ${ }^{272}$

Quanto à função social em matéria trabalhista, não se trata de transferir a responsabilidade social do Poder Público aos empregadores, mas sim de estimulá-los a se apropriarem de uma responsabilidade que lhes pertence pelo simples fato de exercerem uma atividade lucrativa sob sua conta e risco, criando expectativas sociais objetivamente criadas a partir do papel institucional desempenhado. Não se espera nada além do previsto no

${ }^{271}$ COMPARATO, Fábio Konder. Função social da propriedade dos bens de produção. Revista de Direito Mercantil, São Paulo, n. 63, p. 63-73, 1990. p. 73.

${ }^{272}$ SILVA, José Afonso da. Curso de direito constitucional positivo. 22. ed. rev. atual. São Paulo: Malheiros, 2003. p. 280-281. 
ordenamento jurídico, como por exemplo: não discriminação de empregados em todas as fases da relação de emprego, incluindo a pré e pós-contratual (discriminação por gênero, idade, etnia, estado civil, ideologia, nacionalidade, saúde, etc. ${ }^{273}$; observância dos direitos trabalhistas e dos percentuais para contratação de minorias; eliminação ou neutralização dos riscos inerentes à atividade; viabilização e manutenção do equilíbrio do meio ambiente do trabalho; entre outras.

Por meio da análise integrada dos artigos $7^{\circ}$, inciso XXII, 200, inciso VIII e 225 da Constituição Federal, conclui-se que o Princípio da Defesa do Meio Ambiente, como princípio da ordem econômica (art. 170, inciso VI, da Constituição Federal), preleciona o dever do Estado regular a exploração econômica sem perder de vista a defesa do meio ambiente, nele incluído o do trabalho.

Significa dizer que os interesses econômicos jamais devem se sobrepor ao direito fundamental ao meio ambiente do trabalho equilibrado, devendo o empregador construir, adaptar, instalar e equipar os edifícios e locais de trabalho buscando condições ambientais e sanitárias adequadas; disponibilizar, na medida da necessidade concreta, equipamentos de proteção individual e coletiva, observando a melhor técnica; monitorar as operações e processos de trabalho; prevenir inadequação ergonômica e/ou sobrecarga psicofísica; disponibilizar sem qualquer ônus exames médicos; manter em bom estado de conservação, utilização e funcionamento instalações, maquinários, ferramentas de trabalho, instalações elétricas, sanitárias e o fornecimento de água potável; capacitar empregador em matéria de higiene e segurança do trabalho; comunicar acidentes e enfermidades do trabalho; buscar meios de neutralizar ou reduzir riscos inerentes ao trabalho e ao local de trabalho ${ }^{274}$; entre outras medidas e intervenções.

Convém lembrar que a responsabilidade do empregador em promover e manter um meio ambiente do trabalho equilibrado, um dos instrumentos de efetivação do direito ao trabalho digno e à saúde, não se restringe ao fornecimento de equipamentos de proteção individual e coletiva e ao pagamento de adicionais monetários. O empregador tem ainda o dever de cumprir sua função social consubstanciada também na informação dos trabalhadores sobre os aspectos que põem em riscos sua integridade física, buscando neutralizá-los, se

\footnotetext{
${ }^{273}$ OLIVEIRA, Paulo Eduardo V. O dano pessoal no direito do trabalho. 2. ed. São Paulo: LTr, 2010.

${ }^{274}$ Guilherme Guimarães Feliciano, em aula ministrada no dia 9 de junho de 2010, na disciplina "Saúde, Ambiente e Trabalho: novos rumos da regulação jurídica do trabalho I", ministrada aos alunos da pós-graduação da Faculdade de Direito da Universidade de São Paulo.
} 
possível, ou reduzi-los a níveis tolerantes, sem prejuízo de buscar novas formas de intervenção para promover saúde no trabalho.

Deve o empregador, como beneficiário direto da exploração da atividade econômica, não apenas gerar mais e sim melhores empregos, contribuindo para a efetivação do direito ao trabalho, como um direito econômico-social fundamental, pois, conforme Maria Hemília Fonseca, "a exigência de um direito a trabalhar, além do simples objetivo da sobrevivência física, vincula-se à ideia de dignidade humana e, consequentemente, à valoração do trabalho como forma de realização pessoal" ${ }^{\text {275 }}$. E o alcance da dignidade e da realização pessoal apenas é possível se o trabalho for executado em um contexto capaz de efetivar os direitos fundamentais à saúde, ao trabalho digno e ao meio ambiente do trabalho equilibrado.

${ }^{275}$ FONSECA, Maria Hemília. Direito ao Trabalho: Um Direito Fundamental. São Paulo: LTr, 2009. p. 98. 


\section{UMA RADIOGRAFIA DO TELEMARKETING}

\subsection{Entendendo o telemarketing}

A Associação Brasileira de Telesserviços define telemarketing como "toda e qualquer atividade desenvolvida através de sistemas de telemática e múltiplas mídias, tendo como objetivo as ações padronizadas e contínuas de marketing" ${ }^{276}$. Por telemática entende-se a associação entre telecomunicação e informática.

Edmundo Brandão Dantas, por sua vez, define a atividade como "a utilização planejada de recursos de telecomunicações e informática como forma de se obter lucro direto ou indireto, através da satisfação do mercado consumidor de qualquer bem ou serviço"277.

As definições de Neil Johnson, Bob Stone e John Wyman também reforçam a natureza tecnológica da atividade, além do propósito de atingir a clientela, garantir a eficiência e reduzir custos:

É a técnica de vendas de maior crescimento no mundo. É rápida, barata e combina perfeitamente com as comunicações via satélite, aparelhos de fax e todos os demais equipamentos de telecomunicações ${ }^{278}$.

O telemarketing compreende a aplicação integrada e sistemática de tecnologia e de telecomunicações e processamento de dados, com sistemas administrativos, com o propósito de otimizar o mix das comunicações de marketing usado por uma companhia para atingir seus clientes. O telemarketing desenvolve a interação personalizada com clientes, enquanto, simultaneamente, tenta fazer face às necessidades dois clientes e melhorar a eficiência de custos ${ }^{279}$.

O item 1.1.2 do Anexo II da NR 17, do Ministério do Trabalho e Emprego, entende como trabalho de teleatendimento/telemarketing "aquele cuja comunicação com interlocutores clientes e usuários é realizada à distância por intermédio da voz e/ou mensagens

\footnotetext{
${ }^{276}$ ASSOCIAÇÃO BRASILEIRA DE TELESSERVIÇOS. O que é Telemarketing? São Paulo, 2005. Disponível em: < http://www.abt.org.br/telemarketing.asp>. Acesso em: 12 set. 2012.

${ }^{277}$ DANTAS, Edmundo Brandão. Telemarketing: a chamada para o futuro. São Paulo: Atlas, 2000. p. 69.

${ }^{278}$ JOHNSON, Neil. Os segredos do telemarketing. São Paulo: Littera Mundi, 2000. p. 3.

${ }^{279}$ STONE, Bob; WYMAN, John. Telemarketing. São Paulo: Nobel, 1992. p. 5.
} 
eletrônicas, com a utilização simultânea de equipamentos de audição/escuta e fala telefônica e sistemas informatizados ou manuais de processamento de dados".

Embora o Anexo II da NR 17 mencione os dois termos como sinônimos, há quem diferencie telemarketing e teleatendimento, esclarecendo que a primeira atividade, mais ostensiva, refere-se a ações de marketing, cobranças e vendas (modalidade ativa), enquanto a segunda, mais receptiva, refere-se ao pós-venda, geralmente prestado por um Serviço de Atendimento ao Consumidor (SAC). Optou-se neste estudo pelo uso da palavra telemarketing, mais usado pela literatura e mais difundido entre os usuários desse serviço.

José Augusto Molz evidencia as seguintes características da atividade: método mercadológico eficaz, versátil e com custos razoáveis; garantia do contato permanente para fidelização dos clientes; diminuição dos custos de venda através da eliminação de visitas físicas; possibilidade de reações mais ágeis às ações da concorrência e mudanças de mercado; possibilidade de acessar clientes de outras localidades mais distantes; propicia operações de busca, prospecção, classificação e acompanhamento da clientela ${ }^{280}$.

Algumas vantagens, diga-se de passagem empresariais, também são apontadas por José Augusto Molz, como por exemplo, velocidade de penetração, cobertura de forma controlada, capacidade de mensuração imediata, comodidade para o comprador, comunicação interativa, custo operacional menor, flexibilidade, aglutinação - associação das ações de venda, promoção e marketing - e foco ${ }^{281}$. Contudo, por outro lado, há também desvantagens para os consumidores sujeitos a esse serviço. A impessoalidade, a falta de autonomia e flexibilidade dos teleoperadores, o parcelamento de competências e a insegurança quanto ao conteúdo do registro dos protocolos e das providências solicitadas são algumas das desvantagens.

O ambiente de trabalho onde ocorre a execução dessa atividade é chamado de central de atendimento, contact center ou call Center. Essa última denominação foi adotada pelo Anexo II da NR 17 que, em seu item 1.1.1, o define como "o ambiente de trabalho no qual a principal atividade é conduzida via telefone e/ou rádio com utilização simultânea de

\footnotetext{
${ }^{280}$ MOLZ, José Augusto. Telemarketing - aplicabilidade no Banco do Brasil SA. 2002. 57 f. Dissertação (Mestrado em Economia)-Programa de Pós-Graduação em Economia, Universidade Federal do Rio Grande do Sul, Porto Alegre, 2002.

${ }^{281}$ Ibidem.
} 
terminais de computador". A Health and Safety Executive, entidade independente da GrãBretanha dedicada à saúde, segurança e doença no trabalho, define call center como:

ambiente de trabalho no qual a principal atividade é conduzida através do telefone, utilizando-se simultaneamente terminais de computador (...). Isto inclui partes de empresas dedicadas a essa atividade em linhas internas de ajuda bem como companhias voltadas para essa atividade ${ }^{282}$ (tradução nossa).

O Anexo II da NR 17 não se pôs a descrever o arranjo espacial de um call center, muito embora a configuração seja semelhante em todos os estabelecimentos que se dedicam a essa atividade, independentemente do local, país ou do produto ou serviço explorado.

Entende-se que, por integrar os fatores ambientais do meio ambiente do trabalho, são relevantes para este estudo os aspectos física do ambiente de telemarketing, sobretudo quanto aos aspectos gerais presentes em todo e qualquer estabelecimento para atender à organização do trabalho desse ramo. Portanto, o arranjo espacial do meio ambiente do trabalho em telemarketing é evidentemente funcional à organização e às condições laborais.

O espaço físico do call center, por abrigar muitos trabalhadores, sobretudo teleoperadores, é amplo, equipado com ar-condicionado, sistema de isolamento acústico, forte iluminação artificial e painéis informativos sobre o número de ligações em espera, atendidas e abandonadas. É composto por várias ilhas, que são agrupamentos enfileirados de postos de trabalho, também conhecidos por posições de atendimento ou pela sigla "P.A.", conforme é chamado pelos próprios teleoperadores; cada uma dessas ilhas é fiscalizada por um supervisor de telemarketing.

Em cada posição de atendimento há uma mesa, uma cadeira, um computador, um telefone e um fone de ouvido com um microfone acoplado e, em uma mesma ilha, as posições de atendimento são separadas por baias, impossibilitando que um teleoperador interaja com o outro lotado no posto de atendimento ao lado. O supervisor de cada ilha tem sua mesa em posição estratégica, para que possa enxergar todos os teleoperadores que compõem sua equipe e para monitorá-los através de um sistema em seu computador, que lhe permite saber o tempo de pausa, o tempo de atendimento, o número de ligações efetuadas/atendidas, a jornada de trabalho efetivamente cumprida naquele dia por cada teleoperador, dentre outras informações.

\footnotetext{
${ }^{282}$ HEALTH \& SAFETY EXECUTIVE. Advice regarding call centre working practices. 2006. Disponível em: <http://www.hse.gov.uk/lau/lacs/94-2.pdf>. Acesso em: 31 jun. 2012.
} 
Quanto ao aspecto físico externo, o call center, quando localizado em edifício térreo, possui janelas blindadas visualmente por película escura, para proteger a identidade dos teleoperadores que, em alguns casos, sobretudo quando se trata de telemarketing ativo para cobranças, são orientados a se identificar como a tomadora do serviço, ocultando o local onde se encontram lotados e o sobrenome.

O trabalhador que faz dessa atividade sua profissão é conhecido por teleoperador, definido pela Classificação Brasileira de Ocupação ${ }^{283}$, sob o código 4222-10, como aqueles que

Operam equipamentos, atendem, transferem, cadastram e completam chamadas telefônicas locais, nacionais e internacionais, comunicando-se formalmente em português e/ou línguas estrangeiras. Auxiliam o cliente, fornecendo informações e prestando serviços gerais. Podem treinar funcionários e avaliar a qualidade de atendimento do operador, identificando pontos de melhoria.

A Health and Safety Executive define teleoperador como:

Atendente de chamadas (também conhecido como consultor de serviços ao consumidor/agente/operador) - um indivíduo cujo trabalho requer que ele gaste uma proporção significante de seu tempo de trabalho atendendo a chamadas telefônicas e utilizando simultaneamente terminais de computadores $^{284}$ (tradução nossa).

Registre-se que as duas definições de teleoperador apresentadas são incompletas, pois não fazem menção àqueles que exercem a função na modalidade ativa, ou seja, que se ocupam da atividade no que se refere, por exemplo, à oferta de produtos e serviços e à cobrança dos consumidores inadimplentes.

Entende-se, portanto, que a categoria de teleoperador pode ser melhor definida em duas perspectivas. Na perspectiva funcional, como aqueles que atendem e efetuam chamadas, para ações de venda (incluindo marketing e cadastro), pós-venda (averiguar a satisfação do consumidor, reclamações, solicitações e elogios) e cobrança de consumidores inadimplentes, ativando-se em setores de empresas e postos de trabalhos dedicados ao telemarketing ou em empresas terceirizadas que o exploram como atividade-fim. E na perspectiva técnica, como

\footnotetext{
${ }^{283}$ Documento que reconhece, nomeia, codifica e caracteriza as ocupações do mercado de trabalho brasileiro.

${ }^{284}$ HEALTH \& SAFETY EXECUTIVE. Advice regarding call centre working practices. 2006. Disponível em: $\langle$ http://www.hse.gov.uk/lau/lacs/94-2.pdf>. Acesso em: 31 jun. 2012.
} 
aqueles que exercem sua atividade utilizando simultaneamente terminais de computadores e equipamentos de telefonia, que geralmente conjuga um telefone e um fone de ouvido com um microfone acoplado.

Vale dizer que as teclas numéricas de discagem e de comandos do aparelho de telefone à disposição dos teleoperadores são utilizadas apenas para a sinalização das pausas admitidas pela organização do trabalho (pausa refeição, pausa reunião, pausa treinamento e outras pausas), já que a entrada de chamadas, tanto na modalidade ativa como na modalidade passiva, são distribuídas automaticamente por um roteador, obedecendo a ordem de entrada.

Assim sendo, o controle do ritmo da atividade e do número de chamadas não sofre qualquer interferência dos teleoperadores, cujo ofício na modalidade passiva pode ser acelerado dependendo do número de chamadas em espera que, se não atendidas, somarão ao cômputo chamadas abandonadas, sendo esse um dos critérios para medir o desempenho de cada equipe e de todo o call center. Trata-se de uma medição de considerável impacto na atividade, pois, ao mesmo passo que influencia na satisfação dos consumidores atendidos por aquele call center, os índices dessas ocorrências também são acompanhados pela Agência Nacional de Telecomunicações (ANATEL).

O agrupamento de teleoperadores em ilhas, além de facilitar a fiscalização pelos supervisores, favorece tanto a competição entre teleoperadores de uma mesma equipe como entre as ilhas do call center. O desempenho individual e coletivo é um dos indicadores para premiação (televisores, computadores, folgas, etc.) e para o acesso vertical dos teleoperadores a cargos hierarquicamente superiores e melhor remunerados. Outros indicadores utilizados para a avaliação individual e coletiva são: baixo absenteísmo, respeito ao limite de pausas, qualidade do atendimento, comprometimento com a empresa e cumprimento das metas de atendimento (telemarketing passivo), recuperação de crédito ou vendas concretizadas (telemarketing ativo).

\subsection{Radiografia do telemarketing: Brasil e outros países}

No final da década de 90, após a privatização das empresas públicas e do desmonte do setor produtivo estatal, expandiu-se expressivamente o telemarketing, como um valioso mecanismo para encurtar distâncias entre fornecedores e consumidores, trazendo 
consigo a proposta de gerar novos postos de trabalho. A expansão do telemarketing no Brasil foi impulsionada pela sofisticação tecnológica decorrente do processo de globalização da economia, principalmente no setor da informática e das telecomunicações, que permitiu o acesso a tecnologia de ponta a custos mais acessíveis.

Atendendo as expectativas iniciais, o telemarketing gerou milhares de empregos no país e, embora isso só viesse a ocorrer no final da década de 90, essa atividade já era sugerida pelo Código de Defesa do Consumidor como um dos mecanismos de efetivação do Princípio da Harmonização das relações consumeristas, irradiado da Política Nacional das Relações de Consumo ${ }^{285}$, insculpido no art. $4^{\circ}$, inciso V.

No Brasil, o telemarketing é a principal atividade terceirizada e a segunda maior empregadora, atrás apenas do comércio varejista. Expressivamente, nos três primeiros anos do século XX, o telemarketing cresceu $235 \%$, mesmo em períodos de forte recessão e elevados índices de desemprego ${ }^{286}$.

Cerca de 500 mil pessoas foram empregadas no setor de telesserviços em 2003, contra 465 mil no final de 2002, indicando um crescimento de 7,5\%, superior à expectativa inicial, que era $6 \%{ }^{287}$. Em 2005, eram 600 mil teleoperadores distribuídos em 1.827 empresas, das quais 250 eram terceirizadas; $60 \%$ desses postos de trabalho estavam no Estado de São Paulo $^{288}$ e $45 \%$ acolhiam jovens em sua primeira experiência no mercado de trabalho ${ }^{289}$.

Em 2008, um ano após a aprovação das novas regras para o Serviço de Atendimento ao Consumidor e da regulamentação das condições de trabalho pelo Ministério do Trabalho e Emprego, o número de teleoperadores empregados no setor apresentou queda e o faturamento anual, que era de R $\$ 21$ bilhões, caiu para 471 mil. Apenas em 2009 houve a retomada de crescimento do setor de telesserviços, que empregou cerca de 517 mil teleoperadores, alcançando o faturamento de R \$23,66 bilhões $^{290}$.

\footnotetext{
${ }^{285}$ FILOMENO, José Geraldo Brito. Manual de direitos do consumidor. 10. ed. São Paulo: Atlas, 2010.

286 NOGUEIRA, Claudia Mazzei. O trabalho duplicado: a divisão sexual no trabalho e na reprodução: um estudo das trabalhadoras do telemarketing. São Paulo: Expressão Popular, 2006.

${ }^{287}$ FOLHA ONLINE. Telemarketing gera 500 mil empregos no Brasil, 60\% em SP. São Paulo, 26 dez. 2003. Disponível em: <http://www1.folha.uol.com.br/folha/dinheiro/ult91u78596.shtml>. Acesso em: 29 jun. 2011.

${ }^{288}$ Ibidem.

289 VENCO, Selma Borghi. Tempos moderníssimos nas engrenagens do telemarketing. 2006. 312 f. Tese (Doutorado em Educação)-Faculdade de Educação, Universidade Estadual de Campinas, Campinas, 2006.

${ }^{290}$ ANTONELLI, Valdir. Faturamento do setor crescerá para R\$ 23 bi em 2010. Portal Call Center, São Paulo, set. 2010. Disponível em: <http://portalcallcenter.consumidormoderno.uol.com.br/indicadores/anuario/ faturamento-do-setor-crescera-para-r-23-bi-em-2010>. Acesso em: 29 set. 2011.
} 
Uma pesquisa denominada Global Call Center Industry Project, realizada em 19 países (Estados Unidos, Canadá, Filipinas, Índia, Austrália, Inglaterra, Alemanha, Suécia, Polônia, África do Sul, Brasil, entre outros), coordenada pelas Universidades de Sheffield, da Inglaterra, e Cornell, dos Estados Unidos, evidenciou no Brasil os seguintes indicadores: (a) mais da metade dos call centers $(76 \%)$ foram implantados após o processo de privatização do setor de telecomunicações; (b) $25 \%$ tem mais de 500 posições de atendimento, $25 \%$ tem entre 100 e 500 e $50 \%$ tem mais de 10; (c) a expressiva maioria dos teleoperadores é composta por mulheres (77\%); (d) o tempo médio inicial de treinamento é de 4 semanas; $74 \%$ dos teleoperadores possuem o $2^{\circ}$ grau e $22 \%$, curso superior ${ }^{291}$. Em complementação, Airton Marinho da Silva ${ }^{292}$ e Selma Borghi Venco ${ }^{293}$ noticiam o predomínio de pessoas jovens predominantemente estudantes universitários de instituições de ensino privado - e mal remuneradas.

De acordo com informações fornecidas através da coleta de dados junto ao Sindicato que representa a categoria profissional no Estado de São Paulo, atualmente há cerca de pouco mais de 400 mil teleoperadores empregados no Brasil, cuja população oscila em virtude da alta rotatividade que é comum no setor. Em razão da organização dessa atividade, marcada por forte cobrança, ritmo acelerado e baixa remuneração, o tempo médio de permanência dos teleoperadores no emprego é de dois anos. Contudo, estima o Sindicato que até o final de 2012 estarão empregados cerca de 500 mil teleoperadores.

A quantidade de teleoperadores empregados no país ainda é uma incógnita. Enquanto pesquisas científicas, jornais e o próprio Sindicato que representa a categoria profissional no Estado de São Paulo aponta a quantidade aproximada de 500 mil empregados, recentemente o presidente do Sindicato Paulista das Empresas de Telemarketing, Marketing Direto e Conexões (Sintelmark), Lucas Mancini, estima cerca de 1,3 milhão de teleoperadores, sendo 700 mil terceirizados ${ }^{294}$.

${ }^{291}$ ASSOCIAÇÃO BRASILEIRA DE TELESSERVIÇOS. Pesquisa da PUC-SP radiografa o call center brasileiro. São Paulo, 2006. Disponível em: 〈http://www.abt.org.br/pesquisa.asp?banner=ABT>. Acesso em: 29 jun. 2011.

${ }^{292}$ SILVA, Airton Marinho da; ASSUNÇÃO, Ada Ávila. Negociações sociais para melhoria das condições de trabalho no setor de teleatendimento: o descompasso entre a posição das empresas e a realidade do trabalho. Interface, Botucatu, v. 9, n. 18, p. 553-570, fev. 2005.

${ }^{293}$ VENCO, Selma Borghi. Tempos moderníssimos nas engrenagens do telemarketing. 2006. 312 f. Tese (Doutorado em Educação)-Faculdade de Educação, Universidade Estadual de Campinas, Campinas, 2006.

${ }^{294}$ TRIBUNA DO NORTE. Terceirização de call center das teles é ilegal, diz TST. Natal, Economia, 10 nov. 2012. Disponível em: <http://tribunadonorte.com.br/noticia/terceirizacao-de-call-center-das-teles-e-ilegal-diztst/236293>. Acesso em: 12 nov. 2012. 
O Sindicato da categoria profissional ainda confirmou na entrevista que São Paulo ainda é o estado que mais emprega, acolhendo cerca de $50 \%$ dos teleoperadores do país, distribuídos em pequenas/médias (de 10 a 50 teleoperadores) e grandes empresas (a partir de 50 teleoperadores). Salientou que aquelas que empregam mais de 50 teleoperadores são acompanhadas pelo Sindicato "mais de perto, inclusive porque há necessidade de composição de CIPA".

Acredita-se que dificilmente o setor retomará o expressivo crescimento registrado entre 2005 e 2007, principalmente pela baixa remuneração ofertada e pelas regras instituídas tanto pelo Ministério do Trabalho e Emprego como pelo Ministério da Justiça, que ainda serão abordadas neste Capítulo.

Essa crise enfrentada pelas empresas de telemarketing tem impulsionado a flexibilização das exigências curriculares e de formação para o preenchimento das vagas disponibilizadas, que frequentemente são divulgadas através de panfletos afixados nas instituições escolares de ensino médio e nas universidades privadas, por meio de faixas ostentadas na fachada das empresas que exploram a atividade, em sítios eletrônicos de recolocação profissional e em anúncios de empregos em jornais locais. É intrigante recordar que nas áureas épocas do telemarketing, entre 1998 e 2007, essas vagas eram disputadas por centenas de candidatos, muitos com formação universitária e alta qualificação; o departamento de recursos humanos acumulava centenas de currículos e a equipe de treinamento se empenhava na instrução das turmas de novos teleoperadores, continuamente.

Essa dificuldade das empresas de telemarketing em preencherem vagas disponíveis para teleoperadores conduziu à flexibilização das exigências para contratação e à precarização do treinamento dos recém contratados, diante da necessidade premente de reocupar as posições vagas. Com poucas posições de atendimento a oferecer às empresas clientes, as prestadoras do serviço também tiveram a lucratividade comprometida, a medida que seu faturamento é relacionado a quantidade de posições disponibilizadas para cada uma das tomadoras do serviço.

A insatisfação dos consumidores quanto ao serviço de telemarketing abrange diversos segmentos como, por exemplo, comércio virtual, entretenimento, aviação civil, canais de televisão por transmissão a cabo ou via satélite, serviços de acesso à internet, plano de saúde, bancos e financiadoras, telefonia fixa e, principalmente, telefonia móvel. 
Em agosto de 2012, após a finalização de um relatório compreendendo os meses de março a maio do mesmo ano, que apontou um índice de 26,1 reclamações a cada 100 mil consumidores, uma das operadoras que exploram o ramo de telefonia móvel foi proibida pela ANATEL de vender novos chips em alguns estados, sob a acusação de derrubar ligações em plano que previa quantidade de chamadas ilimitadas, tendo faturado com essa prática cerca de $\mathrm{R} \$ 4,3$ milhões. Outras duas operadoras também foram proibidas de vender novos chips e planos, sob pena de pagamento de multa diária de $\mathrm{R} \$ 200$ mil, tendo a medida cautelar perdurado por cerca de onze dias. Essas empresas já haviam sido proibidas de comercializar chips e planos de telefonia móvel em julho do mesmo ano.

Além da medida administrativa imposta pela ANATEL, o Ministério Público do Paraná requereu a proibição das vendas no estado, o ressarcimento dos consumidores pela operadora e indenização por dano moral coletivo de 100 milhões ${ }^{295}$. No encalço da medida adotada pela ANATEL, consumidores comemoraram a exigência de padrão europeu de atendimento pelo Ministro das Comunicações Paulo Bernardo, enquanto os camelôs protestaram contra prejuízo em razão da proibição da venda de chips ${ }^{296}$.

Em contrapartida, para a retomada da comercialização de chips e planos de telefonia móvel, as operadoras anunciaram investimento de cerca de $\mathrm{R} \$ 20$ bilhões nos próximos dois anos, dos quais $\mathrm{R} \$ 4$ bilhões são decorrentes da medida cautelar e visam atender à exigência de melhoria dos serviços ${ }^{297}$.

Contudo, a qualidade do serviço não é a única reclamação dos consumidores. O atendimento prestado pelos Serviços de Atendimento ao Consumidor tem também despertado a insatisfação dos usuários. Entre janeiro e setembro de 2012, segundo os dados de 170 PROCON's distribuídos pelo país, o número de reclamações contra Serviços de Atendimento ao Consumidor crescer $86 \%$ em relação ao mesmo período de $2011^{298}$.

\footnotetext{
${ }^{295}$ CARAZZAI, Estelita Hass. TIM derruba sinal de propósito, diz ANATEL. Folha de São Paulo, São Paulo, 7 ago. 2012. Disponível em: <http://www1.folha.uol.com.br/mercado/1132964-tim-derruba-sinal-de-propositodiz-anatel.shtml>. Acesso em: 7 ago. 2012.

296 UOL NOTÍCIAS TECNOLOGIA. Anatel deve liberar venda de operadoras suspensas nesta quinta, diz Reuters. 2 ago. 2012. Disponível em: <http://tecnologia.uol.com.br/noticias/ redacao/2012/08/02/anatel-liberavendas-de-operadoras-de-telefonia-movel-suspensas.htm>. Acesso em: 2 ago. 2012. ${ }^{297}$ Ibidem.

298 FOLHA DE SÃO PAULO. Funcionário da Vivo orienta cliente a jogar celular na parede. São Paulo, 16 out. 2012. Disponível em: <http://www1.folha.uol.com.br/mercado/1169719-funcionario-da-vivo-orientacliente-a-jogar-celular-na-parede.shtml>. Acesso em: 16 out. 2012.
} 
Frequentes transferências de ligações, falta de autonomia dos teleoperadores para resolver problemas da relação de consumo, impessoalidade no atendimento, elevado tempo de espera para atendimento, dificuldade para cancelar serviços, desprezo das solicitações dos consumidores, chamadas aos sábados e domingos para oferta de produtos e serviços, tratamento grosseiro e falta de preparo dos teleoperadores para o trato com o público são alguns dos motivos dessa insatisfação.

À guia de exemplo, em julho de 2012, em resposta a reclamação de uma consumidora que afirmara não ter recebido um produto que havia comprado, um dos teleoperadores do Serviço de Atendimento ao Consumidor da empresa respondeu à queixa com várias ofensas, sugerindo a ela que procurasse "macho" para satisfazer suas necessidades sexuais. Após o caso vir a público, outra consumidora da mesma loja reclamou do atendimento. Informou que, após ameaçar processar a empresa, um teleoperador respondeu sua reclamação da seguinte forma: "Espero que seja uma advogada loira, gata e com peitos grandes, por favor. Não vou mandar mais abraços porque esse papo já tá muito melado"299.

Outra situação bastante peculiar ocorreu em outubro de 2012. Um teleoperador de uma empresa do setor de telefonia móvel, ao prestar atendimento a uma consumidora que enfrentava há cerca de dois meses problemas de acesso à internet através de seu aparelho celular, recomendou: "Pega o aparelho e arremesse contra a parede! Resolve na hora"300.

Em um editorial publicado na Folha de São Paulo em 2010 consta que, após um levantamento realizado em oito dos 28 call centers, verificou-se o descumprimento de normas mínimas de atendimento ao consumidor, sobretudo pelas empresas de telefonia e aviação civil, que respondiam com embaraços as reclamações, ao invés de devolverem soluções aos consumidores. Apontou o editorial que os operadores são incapazes de ir além da repetição do $s c r i p t^{301}$ e que a Agência Nacional de Telecomunicações e a Agência Nacional de Aviação Civil exercem fiscalização precária, distanciando-se da sua função maior, que é a defesa do consumidor, devendo, por isso, ser responsabilizadas pelo costumeiro desrespeito aos direitos

\footnotetext{
299 FOLHA DE SÃO PAULO. Loja que mandou cliente "procurar macho" fez mais ofensas, diz outra consumidora, São Paulo, Caderno Mercado, 12 set. 2012. Disponível em: <http://www1.folha.uol.com.br/mercado/1152223-loja-que-mandou-cliente-procurar-macho-fez-mais-ofensasdiz-outra-consumidora.shtml>. Acesso em: 12 set. 2012.

${ }^{300}$ FOLHA DE SÃO PAULO. Funcionário da Vivo orienta cliente a jogar celular na parede. Op. cit.

301 Texto padrão formulado pelas empresas de telemarketing, para ser utilizado pelos teleoperadores junto aos consumidores usuários do serviço nas ligações efetuadas ou recebidas pelos call centers. O emprego dessas falas pré-formuladas é obrigatório, podendo ser punido o teleoperador que delas não fizer uso.
} 
daqueles que pagam por uma prestação adequada ${ }^{302}$. O problema é que as operadoras apenas buscam novos clientes e pouco se preocupam com a qualidade do atendimento e com a qualificação dos profissionais, essenciais ao sucesso do negócio, pois falam em nome da empresa e representam o produto/serviço perante o mercado consumidor.

Neste estudo, foram entrevistados 50 consumidores que responderam as seguintes questões: (1) qual a sua opinião sobre a qualidade e eficácia dos serviços de telemarketing?; (2) na sua opinião, qual o setor em que o serviço de telemarketing é mais crítico/precário?; e (3) aponte o(s) motivo(s) da sua satisfação ou insatisfação com os serviços de telemarketing.

A Figura 4, a seguir apresentada, ilustra a opinião dos participantes consumidores sobre os serviços de telemarketing:

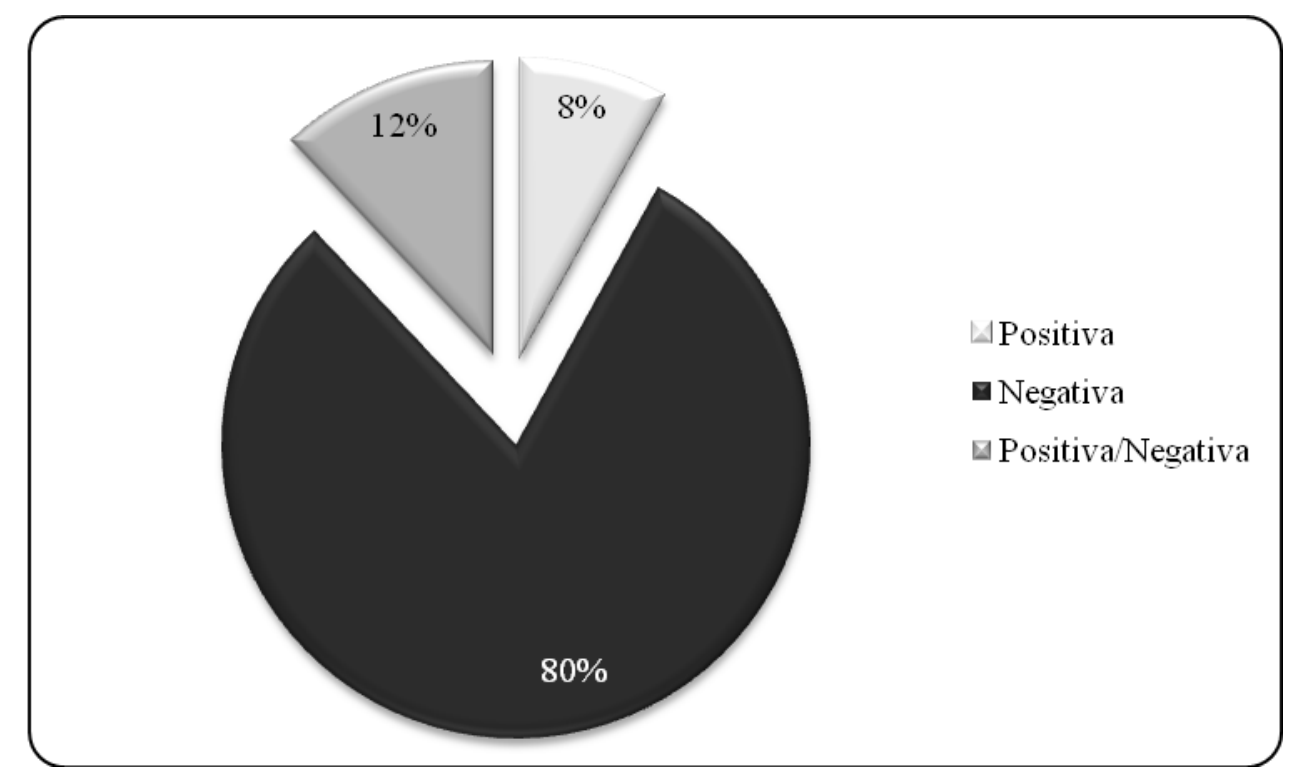

Figura 4. Opinião dos consumidores participantes sobre a qualidade e eficácia dos serviço de telemarketing.

Considerando a totalidade de consumidores entrevistados (50), 80\% (40) manifestou insatisfação em relação aos serviços de telemarketing, mencionando opiniões negativas (incluindo: descaso, inadequados, ineficazes, insatisfatórios, não atendem as expectativas, péssimos, precários, ruins); dentre esses consumidores, 3 também são operadores de telemarketing. Apenas 4 participantes (8\%) apontaram que frequentemente tem seus problemas resolvidos por meio dos serviços de telemarketing, manifestando opiniões

302 FOLHA DE SÃO PAULO. Editorial, 13 jun. 2010. Disponível em: <http://www1.folha.uol.com.br/ fsp/opiniao/fz1306201002.htm>. Acesso em: 12 set. 2012. 
positivas; 6 participantes (12\%) apresentaram argumentos positivos e negativos, no sentido de que nem todas as empresas do setor prestam um serviço de má qualidade.

A Figura 5 ilustra os Serviços de Atendimento ao Consumidor mais criticados pelos consumidores participantes, organizados por setores.

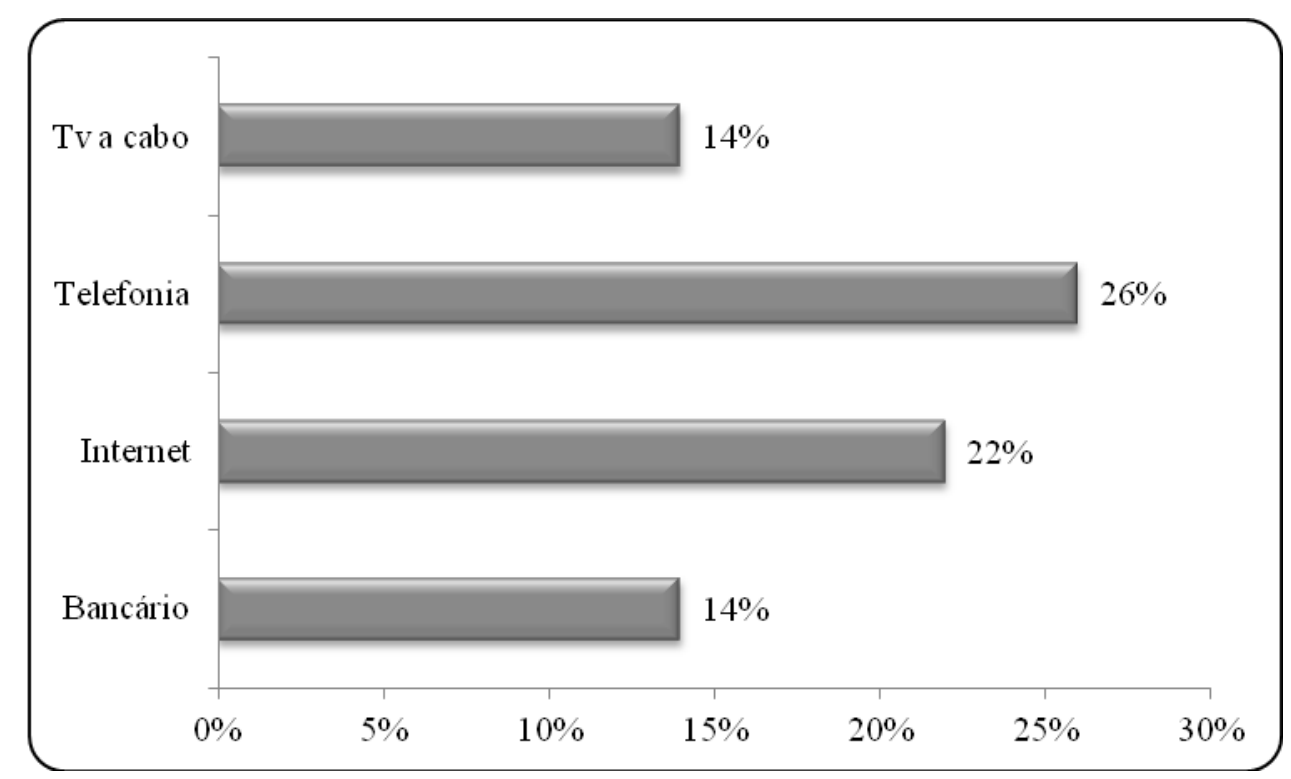

Figura 5. Serviços de Atendimento ao Consumidor mais criticados, organizados por setores.

Observou-se que o setor de telefonia foi o mais apontado pelos consumidores (26\% - 13 participantes), seguido dos provedores de internet (22\% - 11 participantes), das operadoras de TV a cabo (14\% - 7 participantes) e do setor bancário (14\% - 7 participantes). Dois participantes $(4 \%)$ apontaram outras atividades (concessionária de veículos e fabricante de brinquedos) e 10 participantes (20\%) não opinaram.

A predominância da indicação do setor de telefonia confirma a precariedade dos serviços de telemarketing mantidos por esse segmento, conforme evidencia a literatura já comentada nas linhas anteriores, justificando as recentes medidas e sanções aplicadas recentemente pela ANATEL contra algumas empresas de telefonia móvel.

A Figura 6 ilustra as justificativas da insatisfação com os serviços de telemarketing apontadas pelos consumidores. Nessa questão, os participantes podiam indicar uma ou mais justificativas. A análise das respostas indicadas pelos 50 participantes evidenciou 86 justificativas (100\%) agrupadas em 5 categorias: (1) atendimento demorado (incluindo múltiplas transferências, demora na resolução do problema, confirmação de dados 
por diversas vezes); (2) atendimento ineficiente (incluindo informações equivocadas, falta de autonomia dos teleoperadores para a solução de problemas, imprevisibilidade, desconhecimento de procedimentos, produtos elou serviços); (3) má-fé/agressividade do atendente (incluindo chamadas "derrubadas", inclusão de produtos e serviços sem adesão do consumidor, agressões verbais desferidas pelos teleoperadores); (4) treinamento precário (incluindo despreparo funcional e incapacidade dos teleoperadores para lidar com público); (5) longa espera para atendimento (fila de espera para atendimento).

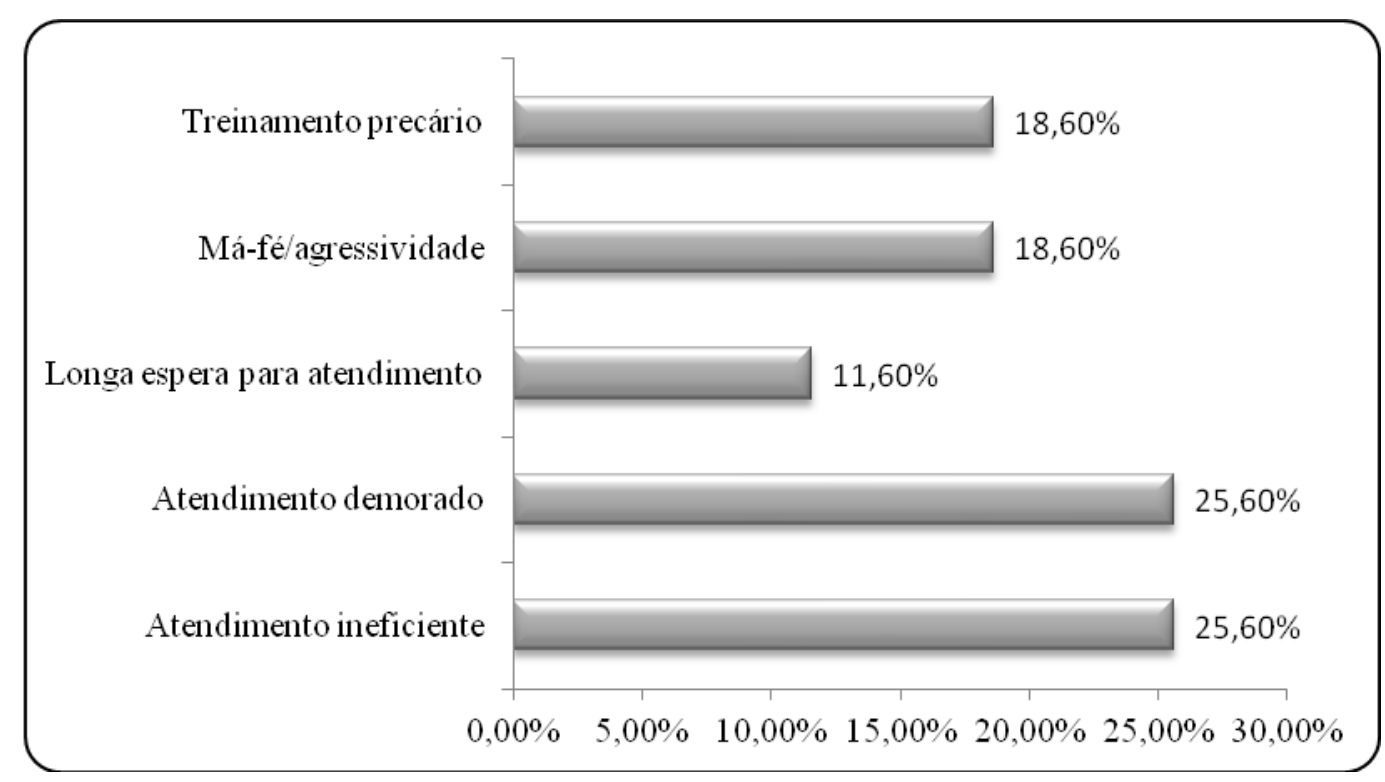

Figura 6. Justificativas da insatisfação com os serviços de telemarketing.

Observou-se que a demora (25,6\% - 22 participantes) e a ineficiência $(25,6 \%-22$ participantes) do atendimento foram as justificativas mais apontadas pelos consumidores, seguidas da má-fé/agressividade dos teleoperadores (18,6\% - 16 participantes), do treinamento precário a que são submetidos (18,6\% - 16 participantes) e da longa espera para $\mathrm{o}$ atendimento $(11,6 \%-10$ participantes $)$.

Para ilustrar esses dados, seguem alguns recortes das entrevistas feitas junto aos consumidores:

Na minha opinião, como operadora de telemarketing e consumidora, acredito que os atendimentos não são adequados. Como operadora acredito que falta treinamento ao funcionário, melhores condições de trabalho e melhor seleção do perfil. Devem ser melhor avaliadas as características dos futuros teleoperadores, pois, pela falta de mão de obra, são contratadas pessoas sem qualquer perfil. Como consumidora, percebo essa falta de treinamento. Os operadores normalmente não tem conhecimento básico sobre o produto ou 
serviço solicitado, às vezes falta até educação. Quando precisamos de um cancelamento ou reclamação o serviço é ainda pior, não se conseguindo nem o contato com o fornecedor. Quando é um telemarketing ativo, a insistência em oferecer um produto ou serviço acaba deixando o cliente nervoso, irritado, devido a essa pressão de venda. (Participante: CS 4).

Na maioria das vezes, eles não perguntam se queremos contratar o serviço oferecido. Simplesmente pedem a confirmação dos dados e endereços. (Participante: CS 18).

Algumas empresas de telemarketing deveriam rever o atendimento que prestam, pois, ao entrarmos em contato com o teleatendimento, ficamos por vários minutos apertando teclas e teclas, tentando achar o setor correto. Depois vem um atendente que te enche de perguntas, fazendo vocês esperar mais alguns minutos. Ao retornar, diz que vai encaminhar ao setor responsável. Depois outra pessoa te atende e te enche das mesmas perguntas, deixando você ainda mais irritado. (Participante: CS 33).

Alguns funcionários, por sua vez, atendem de forma agressiva o consumidor, fazendo com que ele passe por momentos constrangedores. O consumidor passa horas pendurado no telefone e muitas vezes desliga sem ter seu problema resolvido. (Participante: CS 36).

Sempre que entramos em contato com o teleatendimento de uma empresa terminamos a ligação estressados. Ficamos horas na espera de atendimento, a ligação cai várias vezes e o atendente não sabe passar as informações corretas. Muitas vezes é necessário entrar em contato com a ANATEL para que alguém nos ajude e solucione o problema. (Participante: CS 37).

No entanto, a insatisfação com o telemarketing não é uma queixa apenas de consumidores. Aqueles que se encontram do outro lado da chamada, os teleoperadores, também manifestaram insatisfação com a atividade. Não protestaram, não reivindicaram publicamente como fizeram os consumidores. Denunciaram a precarização da atividade silenciosamente, por meio dos elevados índices de absenteísmo, de afastamento da atividade laboral por motivo de saúde, das infindáveis reclamações trabalhistas ajuizadas perante a Justiça do Trabalho - muitas delas denunciando situações de assédio e dano moral - e, em alguns casos, por intermédio do respectivo sindicato.

Vale adiantar que consumidores e teleoperadores concordam em pelo menos um aspecto: a organização do trabalho em telemarketing contribui para a insatisfação desses atores sociais tanto na perspectiva econômica como social (do trabalho). Diante dessa tensão de interesses, cabe examinar as consequências da precarização do trabalho em telemarketing, o que se fará a seguir. 


\subsection{A precarização do trabalho em telemarketing}

Apesar da expressiva lucratividade das empresas do setor e da abertura de novos postos de trabalho, se o sucesso do telemarketing parecia uma solução para um período de forte recessão e crescente desemprego no país, as precárias condições laborais, marcadas pela rígida organização do trabalho, passaram a repercutir na saúde dos trabalhadores ${ }^{303}$.

O telemarketing, que se consagrou a partir do final de década de 90 como um importante mecanismo da Política Nacional de Harmonização da Relação de Consumo, tornou-se, sem demora, arena de infindáveis lides trabalhistas nos últimos tempos, impulsionando diversos estudos científicos das mais diversas áreas do conhecimento.

É por isso que, em 24 de maio de 2011, o Pleno do Tribunal Superior do Trabalho reconheceu e penosidade da atividade de telemarketing e cancelou a Orientação Jurisprudencial $n^{\circ} 273$ da Seção Especializada de Dissídios Individuais 1, que vedava a aplicação por analogia aos teleoperadores da jornada reduzida de que trata o artigo 227 da Consolidação das Leis do Trabalho, fixando em seis horas a jornada de trabalho para essa categoria profissional. Com razão o Tribunal Superior do Trabalho, pois o telemarketing

É um trabalho desgastante para a pessoa humana; é o tipo de trabalho que, por si ou pelas condições em que exercido, expõe o trabalhador a um esforço além do normal para as demais atividades e provoca desgaste acentuado no organismo humano. É o trabalho que, pela natureza das funções ou em razão de fatores ambientais, provoca uma sobrecarga física e/ou psíquica para o trabalhador. ${ }^{304}$

Os estudos de Carla Oda ${ }^{305}$, Leonilde Ribeiro Galasso ${ }^{306}$, Cláudia Mazzei Nogueira $^{307}$ e Simone Santos Silva Oliveira ${ }^{308}$ abordaram os impactos da atividade de

\footnotetext{
${ }^{303}$ RIBEIRO, Silvia Basílio. Telemarketing enfrenta crise de saúde. Folha de São Paulo, São Paulo, 14 mar. 2004. Caderno Ilustrada, p. E2.

${ }^{304}$ MELO, Raimundo Simão de. Direito ambiental do trabalho e a saúde do trabalhador: responsabilidades legais, dano material, dano moral, dano estético, indenização pela perda de uma chance, prescrição. 4. ed. São Paulo: LTr, 2010. p. 208.

305 ODA, Carla. Operadores de telemarketing: stress, autonomia, somatização e dores em pescoço e ombros. 138 f. Dissertação (Mestrado em Psicologia) - Instituto de Psicologia, Universidade de São Paulo, São Paulo, 2003.

${ }^{306}$ GALASSO, Leonilde Ribeiro. Humor e estresse no trabalho: fatores psicossociais estressores e benéficos no trabalho dos operadores de Telemarketing. 2005. 260 f. Tese (Doutorado em Saúde Pública)-Faculdade de Saúde Pública, Universidade de São Paulo, São Paulo, 2005.

307 NOGUEIRA, Claudia Mazzei. O trabalho duplicado: a divisão sexual no trabalho e na reprodução: um estudo das trabalhadoras do telemarketing. São Paulo: Expressão Popular, 2006.
} 
telemarketing, sobretudo dos aspectos organizacionais e das condições de trabalho na saúde dos teleoperadores, evidenciando diversas variáveis causais que justificam o adoecimento (físico e psicológico) desses trabalhadores e os altos índices de afastamento e rotatividade no setor. Dentre essas variáveis causais se encontram: ritmo alucinante de trabalho, impossibilidade de interação entre os colegas de trabalho, escassez de pausas para descanso, metas de produtividade desgastantes (Tempo Médio de Atendimento - TMA; ou Tempo Médio Operacional - TMO), postura estática, movimentos repetitivos, pressão constante de supervisores, controle rígido de trabalho, inadequação do mobiliário e dos equipamentos, penosidade do ambiente de trabalho, baixos salários, sistemas de avaliação e fardo emocional de lidar com clientes exigentes ou desagradáveis, entre outras.

Diversos estudos apontam características tayloristas na organização do trabalho em telemarketing, tais como "o parcelamento de tarefas, a divisão entre o planejamento e a execução, a prescrição do trabalho e o controle dos tempos e movimentos" ${ }^{\text {309 }}$. Na visão de Selma Venco, as centrais de atendimento podem ser consideradas as fábricas modernas, assim como os trabalhadores, os novos operários do setor terciário, a medida que alguns aspectos peculiares ao modelo taylorista (trabalho penoso, flexibilização da mão de obra, baixa remuneração, parcelamento do processo produtivo, etc.) estão igualmente presentes no contexto de telemarketing ${ }^{310}$.

Reforça Ruy Braga a patente influência do modelo taylorista nas atividades laborais contemporâneas, especificamente no telemarketing, com a fixação de ritmos produtivos através de procedimentos rígidos e da utilização de tecnologias informacionais para o controle do trabalho dos teleoperadores pelos supervisores, justificando a degradação da atividade e das condições laborais do teleoperador ${ }^{311}$.

Carla $\mathrm{Oda}^{312}$ e Leonilde Ribeiro Galasso ${ }^{313}$ ainda apontam as principais queixas de saúde registradas pelos teleoperadores, incluindo: laringite, problemas auditivos e vocais,

\footnotetext{
${ }^{308}$ OLIVEIRA, Simone Santos Silva. Um olhar sobre a saúde a partir da dimensão gestionária do trabalho: contradições e ambigüidades no telemarketing. 184 f. Tese (Doutorado em Saúde Pública) - Escola Nacional de Saúde Pública, Fundação Oswaldo Cruz, Rio de Janeiro, 2007.

309 VENCO, Selma Borghi. Centrais de atendimento: a fábrica do século XIX nos serviços do século XXI. Revista Brasileira de Saúde Ocupacional, São Paulo, v. 31, n. 114, p. 7-18, jul./dez. 2006. p. 8.

${ }^{310}$ Ibidem.

311 BRAGA, Ruy. Uma sociologia da condição proletária contemporânea. Tempo Social, Revista de Sociologia da USP, São Paulo, v. 18, n. 1, p. 133-152, 2006.

312 ODA, Carla. Operadores de telemarketing: stress, autonomia, somatização e dores em pescoço e ombros. 138 f. Dissertação (Mestrado em Psicologia)-Instituto de Psicologia, Universidade de São Paulo, São Paulo, 2003.
} 
LER/DORT, tensão muscular, dores de cabeça e pescoço, alterações psicológicas, estresse, depressão, ansiedade, perturbação do sono, incapacidade de relaxamento, irritabilidade, choro fácil, sensação de abatimento e esgotamento, dificuldade de concentração e memória, agressividade, entre outras.

Maria Nerita de L. S. Belo ainda esclarece que teleoperadores sofrem também de dor localizada na região cervical, com irradiação para ao membros superiores, desencadeadas por várias situações inerentes ao trabalho em telemarketing, como alta pressão de trabalho, utilização intensiva de computadores, acumulação de várias tarefas, intensa demanda de processamento de informações e rotina de trabalho sem autonomia para tomada de decisões ${ }^{314}$. Segundo Venética Correia Santos, a intensificação do trabalho e o parco tempo de atendimento requerem a execução de diversas tarefas simultâneas pelos teleoperadores, incluindo falar, digitar e acessar diversas janelas. A rigidez postural e os riscos de doenças ocupacionais são consequências dessa mobilização cognitiva funcional ${ }^{315}$.

O nexo causal entre a execução do serviço e o acidente do trabalho ou doença ocupacional atestado por diversas pesquisas científicas, inclusive as referenciadas acima, tem sido reconhecido inclusive pelos Tribunais, conforme a seguir se observa:

OPERADORA DE TELEMARKETING. TENDINITE. NEXO CAUSAL. REDUÇÃO DA CAPACIDADE LABORATIVA. DANO MORAL. O caráter penoso da atividade das operadoras de telemarketing tem sido alvo de estudos interdisciplinares que merecem inteira consideração dos juslaboristas. A pesquisadora Cláudia Mazzei Nogueira, da PUC (in "O Trabalho Duplicado"- A divisão sexual no trabalho e na reprodução: um estudo das trabalhadoras do telemarketing, Editora Expressão Popular, 2006), conclui que "a rotina das teleoperadoras é exaustiva e pesada. As ações são repetitivas e submetidas a um rigoroso controle por parte da empresa, o que pode gerar, muitas vezes, problemas de ordem física e psicológica. Dentro dessa rotina, diversos fatores de risco estão presentes para o adoecimento da trabalhadora, entre eles: - Ritmo alucinante de trabalho; - Ausência de pausas para recuperar o organismo; - Metas de produtividade desgastantes- TMA; - Movimentos repetitivos; - Pressão constante de supervisores com controle rígido do trabalho; - Insalubridade do ambiente de trabalho; - Inadequação do mobiliário e dos equipamentos; -

\footnotetext{
${ }^{313}$ GALASSO, Leonilde Ribeiro. Humor e estresse no trabalho: fatores psicossociais estressores e benéficos no trabalho dos operadores de Telemarketing. 2005. 260 f. Tese (Doutorado em Saúde Pública)-Faculdade de Saúde Pública, Universidade de São Paulo, São Paulo, 2005.

${ }^{314}$ BELO, Maria Nerita de L. S. A importância da fisioterapia preventiva para os operadores de telemarketing. 2008. 71 f. Monografia - Universidade Veiga de Almeida, Rio de Janeiro, 2008. Disponível em: <http://www.uva.br/cursos/graduacao/ccbs/fisioterapia_monografias/importancia_da_fisioterapia_preventiva_pa ra_os_operadores_de_telemarketing.pdf >. Acesso em: 23 maio 2011.

315 REZENDE, Marcello Santos; BRITO, Jusssara; ATHAYDE, Milton. A automobilização de uma teleatendente para enfrentar as adversidades do trabalho em um Call Center. Revista Laboreal, Porto, v. 5, n. 2, p. 63-75, 2009.
} 
Postura estática". Enfatiza ainda, a presença constante de doenças do tipo LER-DORT, distúrbios auditivos, comprometimento das cordas vocais com o aparecimento de nódulos, e problemas relativos à saúde mental, com a ocorrência de sintomas diversos, p. exemplo, a "automatização do pensamento", semelhante à "neurose das telefonistas" (1956, Le Guillant). In casu, o perito do Juízo constatou o nexo causal entre a doença (tendinite) e a atividade desenvolvida na empresa, que implicava movimentos repetitivos, resultando na redução da capacidade laborativa. Cabe pois, ao empregador, reparar o dano moral decorrente. (TRT $2^{\mathrm{a}}$ Região. RO 01236200504302003. Relator Ricardo Artur Costa e Trigueiros. 27/05/2008).

A figura a seguir apresenta a quantidade de acidentes do trabalho no setor de teleatendimento (classe 82.20-2 da Classificação Nacional de Atividades Econômicas 2.0) no período de 2006 a $2011^{316}$, com e sem emissão de CAT, elaborada a partir dos Anuários Estatísticos da Previdência Social (AEPS) ${ }^{317}$ divulgados no período de 2006 a 2011 :

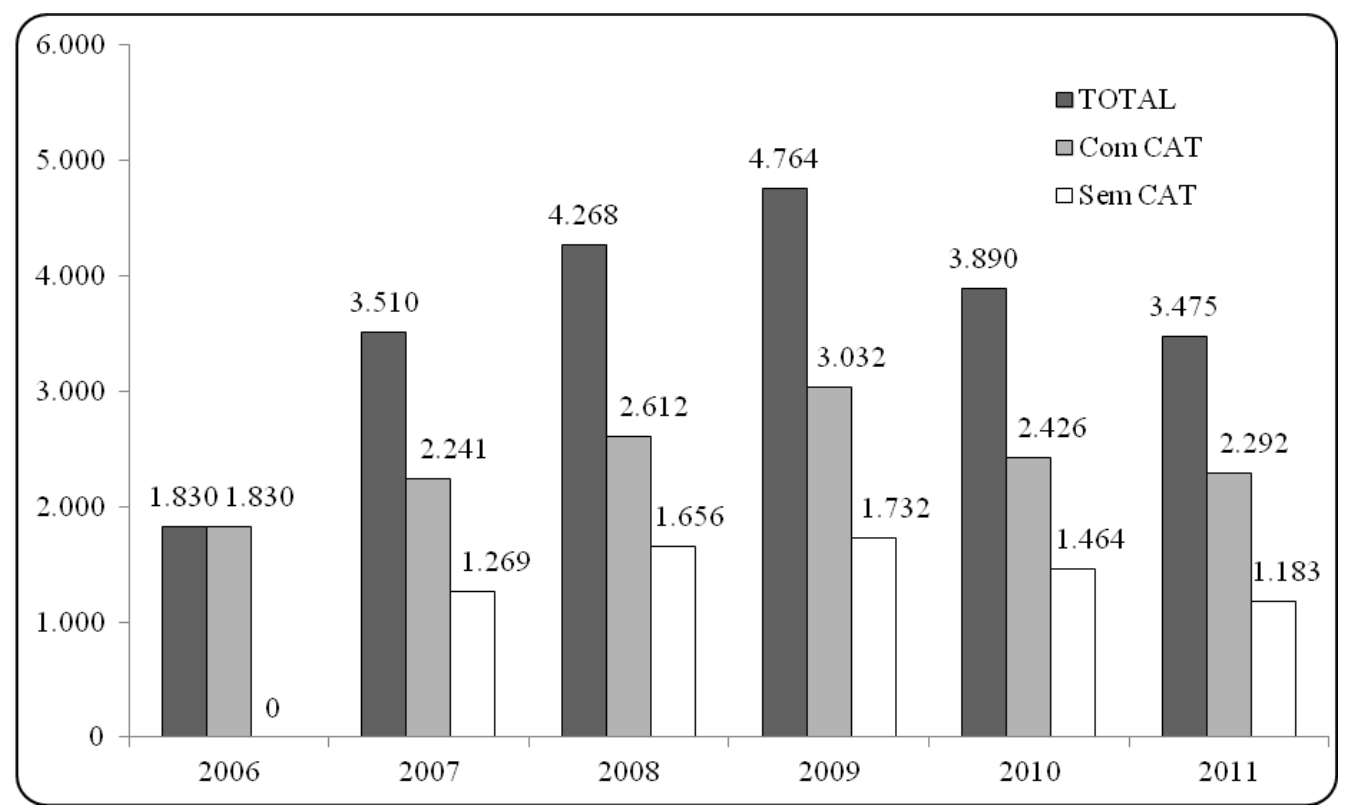

Figura 7. Quantidade de acidentes do trabalho no setor de teleatendimento, com e sem emissão de Comunicação de Acidente do Trabalho (CAT), segundo a Classificação Nacional de Atividades Econômicas (CNAE) - 2006/2011.

Observa-se que, nos anos de 2006 a 2008, houve um aumento progressivo na quantidade de acidentes do trabalho no setor. Surpreendentemente, foi o ano de 2009 que registrou o maior número de acidentes do trabalho, muito embora já se encontrasse vigente o

\footnotetext{
${ }^{316}$ Os anuários anteriores a 2006 não fazem qualquer menção aos trabalhadores em teleatendimento.

317 MINISTÉRIO DA PREVIDÊNCIA SOCIAL. Anuário Estatístico da Previdência Social / Ministério da Previdência Social. Brasília: MPS/DATAPREV, 2006/2011. Disponível em: <http://www.previdencia.gov.br/ conteudoDinamico.php?id=423>. Acesso em: 15 set. 2012.
} 
Anexo II da NR 17, aprovado em 2007, que que estabeleceu parâmetros para a adaptação das condições de trabalho às características psicofisiológicas dos trabalhadores. A Previdência Social não divulgou a quantidade de acidentes do trabalho em 2006 sem emissão de CAT.

Em um primeiro momento, o exame dos dados referentes aos anos de 2010 e 2011 pode levar à conclusão otimista de que houve redução da quantidade de ocorrências de acidentes do trabalho no setor de teleatendimento. Contudo, a leitura desses dados deve considerar três pontos: (a) a queda das contratações conferida a cada ano após o período de adaptação do setor ao Anexo II da NR 17 e ao Decreto ${ }^{\circ}$ 6.523/08; (b) a alta rotatividade do setor; e (c) os dados referentes ao ano de 2011 são parciais, uma vez que apenas no Anuário de 2012, ainda não divulgado, constarão os dados definitivos daquele exercício. Logo, estimase que essa redução está mais relacionada à diminuição da quantidade de teleoperadores empregados do que, necessariamente, à neutralização dos riscos por meio do cumprimento do Anexo II da NR 17.

Essas justificativas também devem ser consideradas na leitura da figura a seguir, que exibe a quantidade de acidentes de trabalho por situação do registro e motivo no mesmo período:

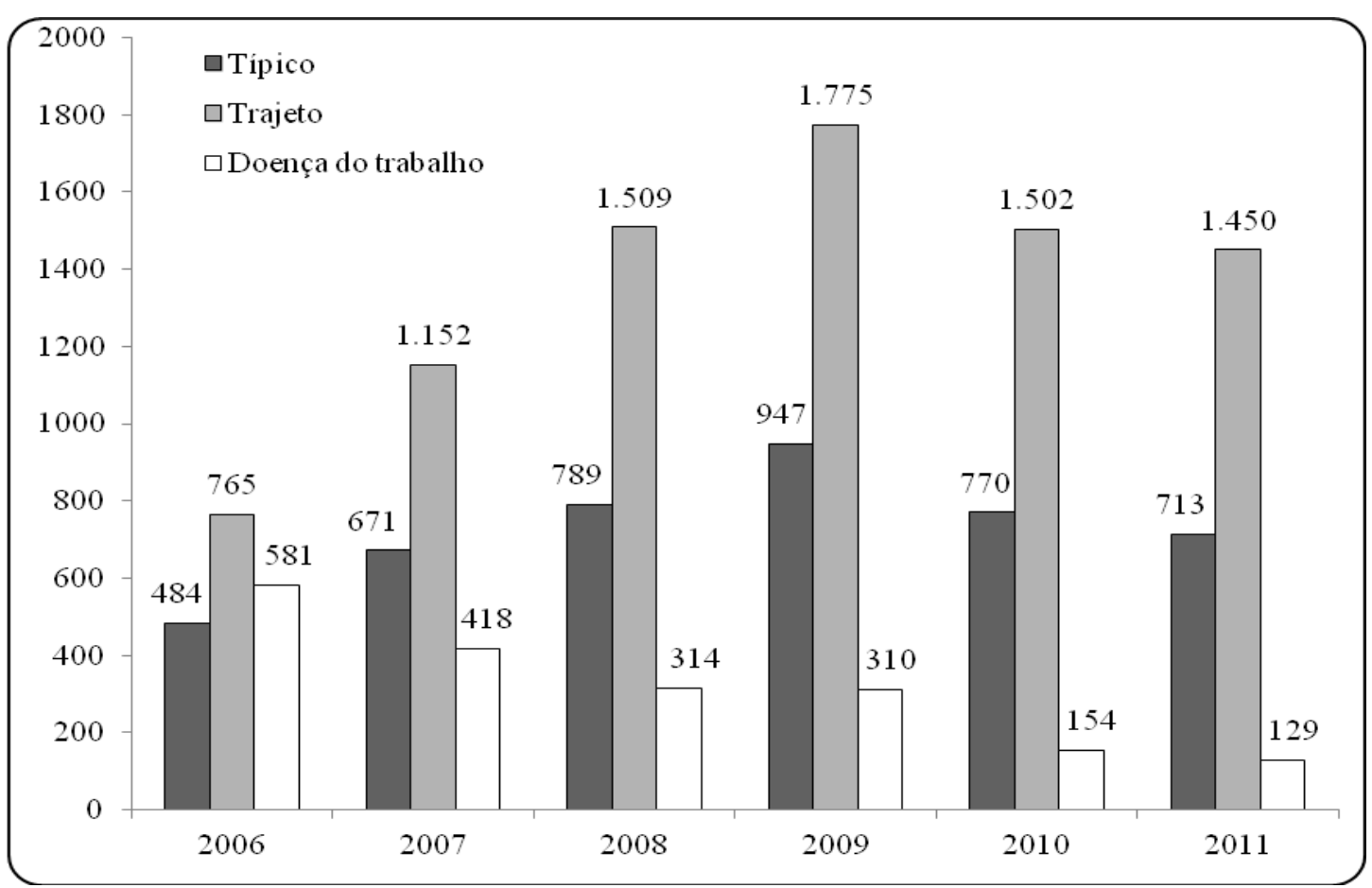

Figura 8. Quantidade de acidentes do trabalho no setor de teleatendimento, por situação do registro e motivo, segundo a Classificação Nacional de Atividades Econômicas (CNAE) - 2006/2011. 
Todavia, estima-se que a quantidade de acidentes do trabalho no setor de teleatendimento seja bem superior aos resultados apresentados pela Previdência Social, pois os dados foram extraídos do Sistema Único de Benefícios (SUB) e do Sistema de Comunicação de Acidente do Trabalho, alimentados pela DATAPREV, que consideram somente as informações cadastradas nas agências da Previdência Social ou pela internet para concessão de benefícios previdenciários. Desconsideram, portanto, situações ignoradas pela Previdência Social, como por exemplo: (a) acidentes do trabalho não comunicados ao órgão previdenciário por diversos motivos (falta de instrução do trabalhador, temor da perda do emprego, etc.); (b) acidentes reconhecidos posteriormente pela Justiça do Trabalho e, por terem sido indenizados, não houve emissão de CAT e requerimento do benefício previdenciário; e (c) não reconhecimento de algumas doenças comuns no setor de teleatendimento, sobretudo psicológicas, como doenças do trabalho.

As doenças psicológicas também se encontram latentes no contexto de telemarketing, embora dificilmente sejam reconhecidas como doenças do trabalho. Segundo o Sindicato da categoria no Estado de São Paulo, “depressão e estresse são sintomas que se apresentam cada vez com mais frequência em operadores de telemarketing”, em razão da forte cobrança para o alcance de metas, das atitudes grosseiras do público, da repetição à exaustão do mesmo script e "brincadeiras desagradáveis" dos superiores hierárquicos ${ }^{318}$.

As práticas chamadas por Silvia Basílio Ribeiro de "brincadeiras desagradáveis" ${ }^{319}$ dos superiores hierárquicos ganharam grande repercussão na Justiça do Trabalho, não sendo raros os casos de condenação de empresas do setor por assédio e dano moral. Os trabalhadores que não alcançavam as metas impostas eram compelidos a se fantasiar de palhaço, bruxa, a utilizar roupas do sexo oposto ou até mesmo orelhas de burro.

Argumentavam as empregadoras que se tratava de uma prática motivacional, que pretendia estimular esses teleoperadores a se empenhar para o alcance das próximas metas. Diziam que não havia dolo, ou seja, intenção de ridicularizar esses teleoperadores ou humilhálos perante seus parceiros de trabalho; e que muitos até gostavam de participar desses "momentos de descontração", que também ocorriam em datas festivas.

\footnotetext{
${ }^{318}$ RIBEIRO, Silvia Basílio. Telemarketing enfrenta crise de saúde. Folha de São Paulo, São Paulo, 14 mar. 2004. Caderno Ilustrada, p. E2.

${ }^{319}$ Ibidem.
} 
Contudo, os argumentos dessas empregadoras não sensibilizaram muitos magistrados, que decidiram por condená-las pelos danos pessoais (dano moral ou assédio moral) impingidos contra seus teleoperadores.

O assédio moral em questão não é aquela prática perversa que se estende no tempo e tem como finalidade prejudicar o assediado ao ponto de fazê-lo decidir pela ruptura da relação de emprego. Não se trata do assédio moral definido por Marie-France Hirigoyen como "qualquer conduta abusiva (gesto, palavra, comportamento, atitude) que atente, por sua repetição ou sistematização, contra a dignidade ou integridade psíquica ou física de uma

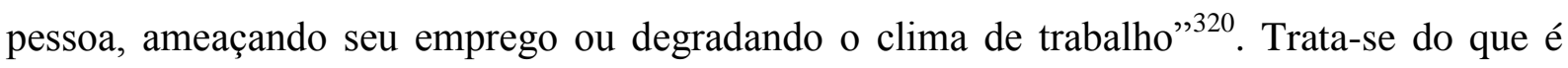
denominado pela doutrina de assédio moral corporativo, entendido por Marie-France Hirigoyen como práticas abusivas, manifestadas de diversas formas, como pela exigência de metas, imposição de objetivos absurdos ou qualquer conduta permeada pela estratégia empresarial ou cultura organizacional, que atente, repetida e sistematicamente, contra a dignidade ou integridade física de um grupo de trabalhadores ${ }^{321}$, nos termos do entendimento jurisprudencial a seguir exposto:

DANO MORAL. ASSÉDIO MORAL ORGANIZACIONAL. RESCISÃO INDIRETA. Não se pode esquecer que a humanidade caminha para frente, para sua libertação, buscando melhores condições de vida e de trabalho e não retrocedendo a um estado comparável à barbárie. O rigor excessivo como prática empresarial para estimular o cumprimento de metas, degradando as condições de trabalho, ignorando o capital humano e as peculiaridades de cada indivíduo, pode configurar o que vem sendo chamado de "assédio moral organizacional". (TRT 15ª Região. RO 0118800-98.2008.5.15.0022. Relatora: Ana Maria de Vasconcellos. Publicação: 09/09/2011).

Por esses motivos, é quase inevitável a presença de estresse, tensão psicológica, ansiedade, depressão, fadiga e esgotamento psicológico no setor de telemarketing ${ }^{322}$. O desafio dos teleoperadores é ver reconhecido o lime entre esses sintomas e a atividade laboral por peritos judiciais ou da Previdência Social, que não os reconhecem como relacionados ao trabalho, obstando o acesso desses trabalhadores ao benefício do auxílio-doença acidentário. Conforme assevera João José Sady, “o topo do sistema pretoriano trabalhista funciona como

\footnotetext{
${ }^{320}$ HIRIGOYEN, Marie-France. Mal-estar no trabalho: redefinindo o assédio moral. 5. ed. Rio de Janeiro: Bertrand Brasil, 2010. p. 17.

${ }^{321}$ Ibidem.

${ }^{322}$ SILVA, Airton Marinho da; ASSUNÇÃO, Ada Ávila. Negociações sociais para melhoria das condições de trabalho no setor de teleatendimento: o descompasso entre a posição das empresas e a realidade do trabalho. Interface, Botucatu, v. 9, n. 18, p. 553-570, fev. 2005.
} 
uma cidadela do positivismo dogmático neste terreno da saúde e segurança do trabalhador”, subsistindo um surdo conflito entre a doutrina jurídica e a jurisprudência, uma vez que muitos juristas apenas reconhecem como relevantes atores agressivos reconhecidos pela Administração Pública ${ }^{323}$.

Não obstante o Decreto $\mathrm{n}^{\circ}$ 6.042/07 tenha instituído o Nexo Técnico Epidemiológico, ampliando o rol de doenças e respectivos agentes etiológicos ou fatores de risco de natureza ocupacional, o desafio ainda persiste, sobretudo quanto às doenças ou transtornos psicológicos desencadeados pela atividade laboral.

Será o caso de um teleoperador que se encontre em estado depressivo em razão da atividade que exerce. Enfrentará esse trabalhador a dificuldade de comprovar o nexo de causalidade junto à Previdência Social para ver deferida a benesse do auxílio-doença acidentário, justamente porque o estado depressivo não apresenta uma causa clara e bem definida, podendo ser desencadeado ou agravado tanto por outros fatores internos (por exemplo, perseguição, forte cobrança, ameaça de demissão, etc.) como externos ao contexto de trabalho (por exemplo, problemas familiares, econômicos, aspectos biológicos, etc.). Restará a esse teleoperador enfrentar os longos e exaustivos trilhos do judiciário para comprovar o nexo de causalidade entre o estado depressivo e as condições de trabalho em que se encontra submetido.

Ainda assim, explica João José Sady que não são raros os casos em que os Tribunais Regionais do Trabalho enfrentam a questão evocando os fins sociais e o bem comum, interpretando extensivamente a legislação, sob o fundamento de que a mera imprevisão no Regulamento da Previdência Social não deve prejudicar o trabalhador, cuja dignidade fora violada por condições de trabalho insalubre, perigosas ou penosas. Contudo, mantendo a blindagem celetista, o Tribunal Superior do Trabalho reforma o acórdão regional, sob o fundamento de que as condições do meio ambiente do trabalho, ainda que atestadas por laudo pericial, não se encontram inseridas nos limites estabelecidos por normas regulamentadoras do Ministério do Trabalho e Emprego ${ }^{324}$.

\footnotetext{
${ }^{323}$ SADY, João José. O direito à sanidade no meio ambiente do trabalho. Revista do Advogado, São Paulo, n. 97, p. 82-88, 2008. p. 87-88.

${ }^{324}$ Ibidem.
} 
Não bastasse, conforme elucida Elizabeth Costa Dias, somam-se aos limites legais outros fatores, como por exemplo, o despreparo dos profissionais da saúde e a desinformação dos trabalhadores sobre os riscos da atividade:

(...) além dos limites legais para o reconhecimento da doença profissional contribuem os entraves da burocracia da Previdência Social, o desconhecimento e despreparo dos profissionais de saúde para fazer o diagnóstico da doença e o nexo com a atividade laboral do paciente, a falta de apoio propedêutico, a desinformação dos trabalhadores sobre os riscos a que estão expostos e de suas consequências para a saúde, somados às lacunas existentes no conhecimento médico-científico sobre a questão.

(...)

A complexidade do problema ganhas novos contornos ao se adentrar no universo das doenças relacionadas ao trabalho. Apesar de ainda pouco definidas no âmbito da medicina, são uma categoria que surge por pressão do movimento dos trabalhadores, interessados ao vê-las reconhecidas, indenizadas e modificadas as condições geradoras ${ }^{325}$.

José Antônio Ribeiro de Oliveira Silva aponta que o despreparo dos peritos judiciais e o parco número desses profissionais a serviço do Poder Judiciário também contribuem para a precária averiguação da contribuição da causa laborativa no surgimento da doença:

O que se tem visto, na maioria dos casos, é uma grande angústia dos juízes, primeiro, porque não conseguem um bom número de peritos que se dispõem a realizar tais perícias; segundo, porque dentre os integrantes do rol disponível, verifica-se a falta de capacitação dos louvados judiciais para a temática específica, mais precisamente para a averiguação da contribuição da causa laborativa no surgimento da doença, ainda que não seja a causa única (concausa); terceiro, por um desconhecimento a respeito do grau de incapacidade que se deve constatar para efeito de indenização de danos de ordem trabalhista (ou civil), diferentemente do que se exige para o deferimento de benefício previdenciário específico, como a aposentadoria por invalidez.

Urge, pois, que a Justiça do Trabalho, mormente por parte da Administração dos Tribunais e das associações de magistrados, envide todos os esforços possíveis para que haja uma melhoria dos serviços periciais, a fim de que se tenha uma efetiva tutela à saúde do trabalhador, seu bem mais importante no âmbito da relação de trabalho.

325 DIAS, Elizabeth Costa. Aspectos atuais da saúde do trabalhador no Brasil. In: ROCHA, Lys Esther; BUSCHINELLI, José Tarcísio Penteado; RIGOTTO, Raquel Maria (Orgs.). Isto é trabalho de gente? Vida, doença e trabalho no Brasil. Petrópolis: Vozes, 1993. p. 147. 
De todo modo, os limites legais, tampouco a burocracia da Previdência Social e a incerteza da verdadeira causa da doença, jamais devem se sobrepor aos direitos fundamentais da dignidade do trabalhador, à saúde, à vida e ao trabalho adequado.

Como bem aponta José Antônio Ribeiro de Oliveira Silva, "não há necessidade de que se descubra a verdadeira causa da doença, bastando que haja uma relação de causalidade - ainda que não seja única", conforme prevê a Lei $n^{\circ}$ 8.213/91, que aborda o nexo causal indireto, pelo simples fato do acidente ter ocorrido durante o curso da atividade laboral ${ }^{326}$.

Para o jurista, "havendo dúvida sobre a existência ou não de nexo causal (ou etiológico) entre a atividade e a doença que acomete o trabalhador, há farta jurisprudência no sentido da presunção do nexo causal, na aplicação do princípio in dubio pro misero" ${ }^{327}$, pois a concausa também é equiparada ao acidente do trabalho típico, nos termos do artigo 21 , inciso I, da Lei $\mathrm{n}^{\mathrm{o}}$ 8.913/91, conforme prevê o entendimento jurisprudencial a seguir colacionado:

CONCAUSA. NEXO ETIOLÓGICO E CULPA. RESPONSABILIDADE CIVIL. A concausa está expressamente prevista no art. 21, I da Lei 8213/91, no art. 133, I do Decreto 2.172 de 05/03/97 e no art. 141, I do Decreto 357 de 17/12/91, caracterizando nexo etiológico com o trabalho. Mesmo que se considere eventual tendência orgânica a determinada lesão, não há como se negar os efeitos ocasionados pelo processo produtivo. É responsabilidade do empregador realizar exames periódicos, encaminhar o trabalhador para tratamento médico, realocá-lo para setor compatível, e tomar todas as medidas que estão ao seu alcance a fim de evitar o desenvolvimento da moléstia. A omissão quanto a essas obrigações contratuais caracteriza culpa, ensejando a responsabilidade civil. 2. DANO MORAL. CARACTERIZAÇÃO. A lesão à integridade psicofísica, por si só, é capaz de causar dano, ainda mais quando causa incapacidade para o trabalho, pois traz repercussões negativas, aptas a causar abalos psíquicos de dor, sofrimento e angustia. A dor sentida, a dispensa ocorrida no momento em que estava com problema de saúde, a dificuldade de recolocação no mercado, os reflexos na vida familiar e social são circunstâncias que caracterizam danos morais. (TRT $2^{\mathrm{a}}$ Região $-4^{\mathrm{a}}$ Turma 02005200526302008 - RO - Acórdão 20090647682 - Relatora Ivani Contini Bramante - Publicado em 28/08/2009).

\footnotetext{
${ }^{326}$ SILVA, José Antônio Ribeiro de Oliveira. As perícias judiciais para a constatação de doença ocupacional: um gravíssimo problema a desafiar uma solução urgente, para a efetiva proteção a saúde do trabalhador . Caderno de doutrina e jurisprudência da Escola de Magistratura da 15a região, Campinas, v. 6, n. 1, fev. 2010. Disponível em: 〈http://bdjur.stj.jus.br/dspace/handle/2011/32491〉. Acesso em: 12 set. 2012. p. 11.

${ }^{327}$ Ibidem, p. 11.
} 
Portanto, é dispensável que o acidente ou a doença ocupacional sejam a causa única da incapacidade laborativa, total ou parcial, bastando a concausalidade, ou causalidade concorrente, que nada mais é do que "a circunstância independente do acidente e que à causa deste se soma para dar o resultado danoso final" ${ }^{328}$. Assim sendo, considerando o Princípio da Interdependência de variáveis proposto neste estudo, os aspectos organizacionais do contexto de telemarketing também devem ser considerados na investigação do nexo causal entre o infortúnio - sobretudo psicológico - e o trabalho.

\subsubsection{Terceirização: um contexto propício para a precarização da atividade}

Não por acaso, escolheu-se o telemarketing como pano de fundo para a contextualização da temática abordada neste estudo. Trata-se de uma das principais atividades terceirizadas no Brasil em proveito de diversos segmentos econômicos (comércio, marketing, pós-venda, serviço de atendimento ao consumidor, etc.), como por exemplo: comércio virtual, entretenimento, TV por transmissão a cabo ou via satélite, provedores de acesso à internet, planos de saúde, transportes aéreo e terrestre, bancos e administradoras de cartões de crédito, operadoras telefonia fixa e móvel, entre outros.

Entende-se por terceirização a relação de emprego triangular, na qual uma empresa (prestadora) contrata trabalhadores para prestar serviços em proveito de uma ou mais empresas (tomadora). O vínculo empregatício é constituído, em tese, entre o empregado terceirizado e a empresa prestadora do serviço, afastando a responsabilidade da empresa tomadora pelos encargos e obrigações trabalhistas. Evidentemente existem exceções a essa isenção de responsabilidade, como é o caso do direito à proteção da saúde do trabalhador e da manutenção do equilíbrio do meio ambiente do trabalho, que devem ser garantidos a todos, independente da condição de empregado ou não.

Sérgio Pinto Martins ainda apresenta outras denominações, como desverticalização, exteriorização, filialização, subcontratação, focalização e parceria ${ }^{329}$. Homero Batista Mateus da Silva acrescenta as expressões outsourcing - contratação de serviços de uma fonte externa - e downsizing - redução do tamanho de uma corporação por meio do repasse de funções acessórias - utilizadas no idioma inglês; e sous-traitance, do

\footnotetext{
${ }^{328}$ NASCIMENTO, Tupinambá Miguel Castro do. Curso de direito infortunístico. 3. ed. Porto Alegre: Fabris, 1992. p. 45.

${ }^{329}$ MARTINS, Sérgio Pinto. Direito do Trabalho. 28. ed. São Paulo: Atlas, 2012. p. 192.
} 
francês, que significa a contratação de serviços que podem ou não ser prestados pelo empregador $^{330}$. Outras denominações também são apontadas, por exemplo, marchandage e horizontalização $^{331}$. Optamos pela adoção do termo terceirização, por ser mais conhecido e já apropriado pela literatura jurídica, econômica, administrativa e por leigos.

Ainda sobre a expressão terceirização, Arion Sayão Romita justifica o uso desse vocábulo em razão da relação desse instituto com o setor terciário (serviços). Porém, considera inadequada tal expressão, por entender que existe de tão somente uma relação bilateral, e não triangular, entre as empresas prestadora e tomadora do serviço ${ }^{332}$. Com a devida vênia, não compartilhamos desse entendimento, pois, na perspectiva juslaboralista, a empresa tomadora do serviço interfere, direta ou indiretamente, na prestação laboral e se beneficia da força de trabalho do empregado terceirizado, caracterizando uma relação de emprego triangular; seja pela interferência da empresa tomadora na organização do trabalho, seja porque, em alguns casos, a empresa prestadora aloca seus trabalhadores no estabelecimento da tomadora. A terceirização pode ser considerada uma relação bilateral apenas na perspectiva civilista da prestação de serviços.

Ademais, conforme não deixa escapar Homero Batista Mateus da Silva, existe um grau de subordinação médio ou moderado nessa modalidade de contratação, "porque a terceirização não oferece, de fato, um desprendimento total do empregado em relação ao benefício dos serviços, mas uma ligação que deve ficar a meio caminho entre a intimidade completa e o estranhamento absoluto",333.

A apropriação do fenômeno da terceirização e sua banalização pelo mercado brasileiro não demorou muito a acontecer. Desprezaram a vantagem da especialização terceirizar para aprimorar os serviços/produtos, utilizando-se de mão de obra específica e qualificada - e o chamariz nefasto, evidentemente, foi a possibilidade de redução dos encargos trabalhistas, econômicos e sociais, em detrimento do equilíbrio do meio ambiente do trabalho e da saúde do trabalhador. Contudo, a finalidade do instituto da terceirização jamais foi o barateamento dos custos da produção. Isso seria consequência e não finalidade.

\footnotetext{
${ }^{330}$ SILVA, Homero Batista Mateus da. Curso de Direito do Trabalho Aplicado: parte geral. v. 1. Rio de Janeiro: Elsevier, 2009. p. 160.

${ }^{331}$ SÜSSEKIND, Arnaldo; MARANHÃO, Délio; VIANNA, Segadas; TEIXEIRA, Lima. Instituições de Direito do Trabalho. 22. ed. v. 1. São Paulo: LTr, 2005. p. 280-282.

${ }_{332}$ ROMITA, Arion Sayão. A terceirização e o Direito do Trabalho. Revista LTr, São Paulo, v. 56, n. 03, p. 273279, mar. 1992.

${ }^{333}$ SILVA, Homero Batista Mateus da. Op. cit., p. 160.
} 
No Brasil, após a expansão do telemarketing como mecanismo de harmonização da relação de consumo, tornou-se costume a terceirização dos serviços de atendimento ao consumidor, independentemente da modalidade - ativa (contato feito pela empresa para cobranças, vendas, marketing, etc.) ou passiva (contato feito pelos consumidores para reclamações, dúvidas, solicitações, informações, etc.). Ocorre, porém, que as empresas prestadoras passaram a terceirizar aquilo lhes era próprio, ligado à atividade-fim. E não se duvida que a finalidade sempre foi a redução dos custos da produção e não a especialização e a qualidade do serviço e/ou produto.

As empresas de telefonia, após a privatização do setor, foram as maiores entusiastas da terceirização de serviços ligados à atividade-fim explorada. Algumas criaram às escuras empresas de telemarketing para prestação de serviço de atendimento aos consumidor, visando afastar a concessão dos benefícios já garantidos por normas coletivas aos empregados da tomadora, por sinal, mais onerosos. Poucos sabem que essas prestadoras de serviço de telemarketing quase sempre pertencem ao mesmo grupo econômico da tomadora do serviço.

Não há no Brasil uma legislação que regulamente a terceirização como ocorre na Bélgica, Dinamarca, Noruega, Países Baixos, França, entre outros países. A inércia do Poder Legislativo levou o Tribunal Superior do Trabalho a tratar do assunto por meio da Súmula $\mathrm{n}^{\circ}$ 331, resultado da revisão da Súmula n 256, por meio da Resolução no 23/1993, alterada em 2000 (Resolução n 96/2000), mantida em 2003 (Resolução 121/2003) e novamente alterada em 2011, pela Resolução 174/2011, que deu nova redação ao item IV e inseriu os itens V e VI.

O inadimplemento das obrigações trabalhistas por parte das empresas de telemarketing implica na responsabilidade subsidiária das empresas tomadoras quanto àquelas obrigações, desde que tenham participado da relação processual e constem também do título executivo judicial, nos termos da Súmula n 331, item IV. A responsabilidade abrange todas as verbas decorrentes da condenação referentes ao período da prestação laboral, nos termos do item VI, acrescido em 2011.

Justiça seja feita, a Súmula $n^{\circ} 331$ do Tribunal Superior do Trabalho procurou corrigir a inventividade perversa daqueles que desvirtuaram o instituto da terceirização, sob o pálio da redução dos encargos laborais, subcontratando empresas sem a menor condição de honrar os direitos mínimos dos trabalhadores resguardados pela legislação trabalhista, quanto 
mais os créditos das execuções judiciais. Através da responsabilização subsidiária das empresas tomadoras, a Súmula n 331 também buscou desestimular a contratação de empresas mal estruturadas e incapazes de exercer qualquer atividade empresarial.

Desde então, muito se discutiu sobre a licitude da terceirização de serviços pelas empresas de telefonia fixa e móvel. O embate visava dirimir o problema jurídico da responsabilidade solidária ou subsidiária da tomadora pela satisfação dos créditos trabalhistas. Até poucos meses, o entendimento majoritário dos Tribunais Trabalhistas era pela responsabilidade subsidiária das empresas tomadoras, com fundamento na Súmula $\mathrm{n}^{\circ} 331$ do Tribunal Superior do Trabalho, calcada nas culpas in eligendo e in vigilando, conforme a seguir se confere:

RECURSO DE REVISTA. RESPONSABILIDADE SUBSIDIÁRIA ILEGITIMIDADE PASSIVA - OPERADORA DE TELEMARKETING. O inadimplemento das obrigações trabalhistas, por parte do empregador, implica a responsabilidade subsidiária do tomador dos serviços quanto àquelas obrigações, desde que haja participado da relação processual e conste também do título executivo judicial - (Súmula n $\mathrm{n}^{\circ} 331$, item IV, desta Corte). Recurso de revista não conhecido. (TST. RR 11940021.2004.5.04.0005. $2^{\mathrm{a}}$ Turma. Relator: Renato de Lacerda Paiva. Publicação: DEJT 26/08/2011).

RESPONSABILIDADE SUBSIDIÁRIA. Não há interesse em recorrer da primeira reclamada, ATENTO BRASIL S/A, quanto à decisão de origem, no aspecto em que, sendo reconhecida a legitimidade passiva da segunda reclamada, é atribuída a esta responsabilidade subsidiária pela satisfação dos créditos trabalhistas reconhecidos à reclamante. Recurso da primeira reclamada do qual não se conhece, por ausência de interesse em recorrer. (TRT 4 a Região. RO 00013-2008-022-04-00-0. Relatora: Ana Luiza Heineck Kruse. Julgamento: 07/05/2009).

RESPONSABILIDADE SUBSIDIÁRIA. TOMADOR DE SERVIÇOS. SÚMULA No 331, IV, DO C. TRIBUNAL SUPERIOR DO TRABALHO. O tomador de serviços é subsidiariamente responsável pelas obrigações decorrentes do contrato de trabalho dos empregados da empresa prestadora de serviço, mesmo em caso de terceirização lícita. Entendimento jurisprudencial cristalizado na Súmula $n^{\circ} 331$, item IV, do C. Tribunal Superior do Trabalho. Apelo a que se nega provimento. (TRT $1^{a}$ Região. RO 0001818-62.2011.5.01.0223. Relator: Rogério Lucas Martins. Julgamento: 28/08/2012).

Ocorre, porém, que a Subseção Especializada de Dissídios Individuais 1 do Tribunal Superior do Trabalho, em composição plena, decidiu recentemente, em 8 de novembro de 2012, pela irregularidade da terceirização do serviço de telemarketing pela empresa de telefonia Claro S/A. Argumentou o Ministro José Roberto Freire Pimenta, autor 
da divergência vencedora, que esse é um dos mais importantes casos destes últimos tempos, em razão da discussão dos limites da terceirização em uma atividade cada vez mais frequente e, também, controvertida.

Recobrando a síntese processual, um teleoperadora, empregada da empresa TMKT Serviços de Telemarketing Ltda. que presta serviços de teleatendimento à Claro S/A, ajuizou reclamação trabalhista perante a $2^{\mathrm{a}}$ Vara do Trabalho de Joinville em 17 de junho de $2010^{334}$. Postulou, entre outros pedidos, o reconhecimento da ilicitude da terceirização e, por corolário, o vínculo de emprego com a empresa tomadora do serviço, Claro S/A. Alegou a teleoperadora que as atividades desenvolvidas pela prestadora do serviço integram a atividade-fim da tomadora, tendo havido subordinação e dependência, em razão do controle exercido pela Claro S/A sobre os funcionários da TMKT Serviços de Telemarketing Ltda., sujeito a sanções caso não operassem nos padrões impostos pela empresa de telefonia.

Em sua defesa, alegou a tomadora que o serviço de call center não é considerado atividade-fim da Claro S/A, sendo lícita a terceirização nos moldes do artigo 94 da Lei no 9.472/97 (Lei Geral de Telecomunicações) e por estarem ausentes os requisitos do art. $3^{\circ}$ da Consolidação das Leis do Trabalho.

Com base no Contrato de Prestação de Serviços de Contact Center carreado aos Autos, cujo objeto era a prestação de diversos serviços (atendimento a clientes, vendas ativas, vendas receptivas, atendimento por chat ou e-mails ou outros canais), decidiu-se em primeira instância pela licitude da terceirização e pelo reconhecimento apenas da responsabilidade subsidiária da empresa tomadora do serviço, com fundamento nos seguintes entendimentos jurisprudenciais do Tribunal Regional da $12^{\mathrm{a}}$ Região:

TERCEIRIZAÇÃO LÍCITA. VÍNCULO DE EMPREGO NÃO CARACTERIZADO. A terceirização lícita não impõe o reconhecimento do vínculo de emprego direto com o beneficiário da mão de obra, mas tão somente a sua responsabilização de forma subsidiária, conforme $\mathrm{o}$ entendimento firmado no item IV da Súmula $\mathrm{n}^{\mathrm{o}} 331$ do TST. (TRT 12 Região. RO 04169-2009-004-12-00-5 - Juiz Gracio R. B. Petrone Publicado no TRTSC/DOE em 23-11-2010).

ISONOMIA SALARIAL. EMPREGADOS DE EMPRESAS DE TERCEIRIZAÇÃO $X$ EMPREGADOS DA TOMADORA DOS SERVIÇOS. IMPOSSIBILIDADE. RELAÇÕES DE TRABALHO DISTINTAS. A isonomia salarial restringe-se ao âmbito da empresa ou

\footnotetext{
${ }^{334}$ Processo n. 02938-2010-016-12-00-4. Origem: 2a Vara do Trabalho de Joinville - Tribunal Regional do Trabalho da $12^{\mathrm{a}}$ Região - Santa Catarina.
} 
categoria profissional, não se estendendo às relações de emprego diversas das empresas de terceirização. (TRT 12 ${ }^{\mathrm{a}}$ Região. RO 04217-2009050-12-00-6 - Juíza Sandra Marcia Wanbier - Publicado no TRTSC/DOE em 21-07-2010).

CONTRATAÇÃO PREVISTA NA LEI N $\mathrm{N}^{\circ}$ 6.019/1974 E DEMAIS HIPÓTESES DE TERCEIRIZAÇÃO. DIFERENCIAÇÃO. O trabalho desempenhado na forma da Lei $\mathrm{n}^{\circ} \quad 6.019 / 1974$ implica reconhecer a inserção do trabalhador na rotina da empresa tomadora dos serviços, a qual está subordinado, porquanto atende à necessidade transitória de substituição de pessoal ou a acréscimo extraordinário de serviços, enquanto nos demais casos de terceirização lícita, o vínculo de emprego se estabelece com o real empregador, ocorrendo a subordinação em relação a este, e não ao tomador dos serviços (TRT 12a Região. RO 01609-2009-050-12-00-3 Juíza Lília Leonor Abreu - Publicado no TRTSC/DOE em 06-05-2010).

TERCEIRIZAÇÃO LÍCITA. ISONOMIA SALARIAL ENTRE EMPREGADO DA PRESTADORA DE SERVIÇO E INTEGRANTES DA CATEGORIA PROFISSIONAL DA TOMADORA. IMPOSSIBILIDADE. Lícita a terceirização, incabível isonomia salarial entre o empregado da prestadora de serviço e os integrantes da categoria profissional da tomadora, visto que as atividades desempenhadas pela obreira referem-se à atividade-meio desta. Tal hipótese afasta a possibilidade de aplicação do inciso XXXII do art. $7^{\circ}$ da Constituição Federal, cuja observância está adstrita a trabalhadores em iguais condições de labor. Igualmente inaplicável por analogia a alínea "a" do art. 12 da Lei $n^{\circ}$ 6.019/74, a qual é norma específica para os trabalhadores contratados temporariamente pela empresa para atender a necessidade de substituição de seu pessoal regular ou em decorrência de acréscimo extraordinário de serviço, prestando os contratados trabalho na atividade-fim desta, como o fazem os empregados da tomadora, razão pela qual a eles se defere o direito à isonomia salarial. (TRT 12 ${ }^{\mathrm{a}}$ Região. RO 02465-2009-030-12-00-8 - Juíza Ligia M. Teixeira Gouvêa - Publicado no TRTSC/DOE em 19-03-2010).

A matéria foi devolvida ao Tribunal Regional do Trabalho da $12^{\mathrm{a}}$ Região, que manteve a decisão de primeira instância, sob o fundamento de que a permissão dada pelo art. 94, inciso II, da Lei $n^{\circ}$ 9.472/1997, que dispõe sobre a organização dos serviços de telecomunicações, retira do âmbito da ilegalidade a prestação de serviços discutida e faz dela exceção à regra geral contida no Direito do Trabalho, que veda a transferência de atividadefim para terceiros. Por esse motivo, entendeu o relator Edson Mendes de Oliveira que, diante da referida norma legal, a discussão quanto à essencialidade das atividades de telemarketing perde seu objeto e, ainda, que o labor prestado pela teleoperadora não estava inserido na atividade-fim da empresa Claro S/A, tomadora do serviço.

Inconformada, a teleoperadora interpôs Recurso de Revista perante o Tribunal Superior do Trabalho, insistindo no reconhecimento do vínculo empregatício em relação à 
tomadora do serviço, Claro S/A. Justificou que a prestação de serviços inseridos na atividadefim da empresa prestadora caracteriza a ilicitude da terceirização, reforçada pela existência de subordinação estrutural. Sustentou, ainda, que o art. 94, inciso II, da Lei nº 9.472/1997, não permite a terceirização da atividade-fim das empresas de telefonia e requereu a aplicação analógica do artigo 12, alínea “a”, da Lei n 6.019/74, apontando ofensa à Constituição Federal (artigo $3^{\circ}$, inciso IV; artigo $5^{\circ}$, caput e incisos V e XXX; e artigo $7^{\circ}$ ), bem como à Súmula no 331/TST, escorando sua pretensão nos seguintes arestos divergentes:

RECURSO DE REVISTA. AÇÃO CIVIL PÚBLICA. SERVIÇOS DE CALL CENTER. ATIVIDADE-FIM. IMPOSSIBILIDADE DE TERCEIRIZAÇÃO. SÚMULA 331, I/TST. As atividades-fim podem ser conceituadas como as funções e tarefas empresariais e laborais que se ajustam ao núcleo da dinâmica empresarial do tomador de serviços, compondo a essência dessa dinâmica e contribuindo inclusive para a definição de seu posicionamento e classificação no contexto empresarial e econômico. Sendo a atividade principal da tomadora a exploração de serviços de telecomunicações em geral, o trabalho executado pelos atendentes de call center é essencial ao seu empreendimento. Pontue-se, ainda, que, nesse contexto, a contratação por empresa interposta é irregular, passível, inclusive, de formação do vínculo de emprego diretamente com o tomador de serviços, na forma da Súmula 331, I/TST, que preserva a compreensão já sedimentada na antiga Súmula 256/TST, no tocante aos efeitos jurídicos decorrentes da terceirização ilícita. Ressalte-se que o inciso II do art. 94 da Lei 9472/97 (que dispõe sobre a organização dos serviços de telecomunicações), não comporta a interpretação de poder a concessionária contratar com terceiros o desenvolvimento de atividades inerentes, acessórias ou complementares ao serviço, concebidas estas como atividadesfim, já que tal exegese confrontaria com o texto da Súmula 331/TST. Estender o sentido do termo - inerente - nessa peculiar hipótese para compreendê-lo como análogo à atividade-fim, aceitando a transferência do desenvolvimento de serviços essenciais a terceiros, significaria um desajuste em face dos clássicos objetivos tutelares e redistributivos que sempre caracterizaram o Direito do Trabalho ao longo de sua história. O fenômeno da terceirização, por se chocar com a estrutura teórica e normativa original do Direito do Trabalho, sofre restrições da doutrina e jurisprudência justrabalhistas, que nele tendem a enxergar uma modalidade excetiva de contratação de força de trabalho. Precedentes desta Corte. Recurso de revista conhecido e provido. (TST. 6 ${ }^{\mathrm{a}}$ Turma. RR 8040-64.2002.5.12.0026. Relator: Mauricio Godinho Delgado. Julgamento: 02/06/2010. Publicação: DEJT 28/06/2010).

Admitido por divergência jurisprudencial quanto à ilicitude da terceirização, o Recurso de Revista interposto pela teleoperadora foi conhecido pelo Tribunal Superior do Trabalho, por maioria de votos da $6^{\mathrm{a}}$ Turma, culminando no reconhecimento do vínculo de emprego diretamente com a tomadora, ressalvado o entendimento pessoal do Ministro Relator 
Aloysio Corrêa da Veiga. Convém, portanto, colacionar a ementa extraída do respectivo acórdão:

RECURSO DE REVISTA. EMPRESA DE TELEFONIA. CALL CENTER. ILICITUDE DA TERCEIRIZAÇÃO. VÍNCULO DE EMPREGO COM A TOMADORA DOS SERVIÇOS. O vínculo de emprego do empregado que trabalha em serviço "central de atendimento", junto à empresa de telefonia, faz-se diretamente com a tomadora de serviços, por representar fraude na relação de trabalho, já que se trata de atividade-fim, sendo ilícita a terceirização. Ressalva do Relator. Recurso de revista conhecido e provido (TST. 6 $6^{\text {a }}$ Turma. RR-2938-13.2010.5.12.0016. Relator: Aloysio Corrêa da Veiga. Publicação: 01/06/2012).

Houve ainda oposição de Embargos de Declaração pela Claro S/A, que foram conhecidos, pois regulares e tempestivos, porém rejeitados, em razão da inexistência das hipóteses previstas no artigo 535 do Código de Processo Civil.

Concordamos com a atual posição do Tribunal Superior do Trabalho sobre a ilicitude da terceirização da atividade de telemarketing pelas empresas do setor de telefonia. $\mathrm{O}$ serviço terceirizado por essas empresas é essencial e não acessório, sobretudo em razão da sua indispensabilidade à manutenção da relação de consumo e da natureza continuada desse liame jurídico.

O telemarketing integra o núcleo dinâmico das empresas prestadoras de serviço de telefonia, sendo essencial (indissociável) ao empreendimento e não meramente acessório ou periférico. Basta lembrar que todos os serviços prestados por essas empresas, desde a oferta até o cancelamento de serviços, são feitos através das centrais de atendimento ao consumidor, constituída por teleoperadores treinados, fiscalizados e orientados geralmente pela própria tomadora do serviço.

As empresas de telefonia que atuam no Brasil, em geral, multinacionais, foram as principais e maiores beneficiárias do serviço de teleatendimento, a partir da privatização do setor de telecomunicações no final da década de 90. A terceirização dessa atividade foi a forma encontrada para reduzir os custos do negócio e, como sempre, foi o contexto laboral que absorveu essa responsabilidade. Diante da acirrada competitividade no mercado de telefonia, a garantia da lucratividade dependia de uma redução ainda maior dos custos da produção. Logo, para a manutenção do contrato de prestação de serviço, as empresas de telemarketing enrijeceram as cobranças e atenuaram as exigências para contratação de teleoperadores, passando a oferecer salários inferiores aos novos contratados. 
Desde então, a literatura científica vem denunciando uma série de artimanhas dessas empresas que culminaram na precarização das condições de trabalho em telemarketing. Não foi por acaso que o Ministério do Trabalho e Emprego aprovou o Anexo II da NR 17, com a finalidade de proporcionar um máximo de conforto, segurança e saúde aos trabalhadores do setor.

Os consumidores também sentiram os impactos dessa precarização, sobretudo aqueles que integram o mercado de massa (pessoas físicas). As próprias empresas tomadoras acabaram por reconhecer a baixa qualidade dos serviços prestados pelas empresas de telemarketing contratadas, ao terceirizar apenas o atendimento ao mercado de massa e não aos clientes preferenciais, aqueles que desembolsam altos valores pelo produto ou serviço. Nítida, portanto, a influência do sistema econômico no meio ambiente do trabalho, quando se conclui pela sua interferência na organização e nas condições laborais, conforme apontou uma dos participantes deste estudo:

Eu acabo de ser informado, que nos planos de saúde terceirizam-se o telemarketing dos clientes em geral e não se terceirizam dos clientes de um determinado patamar dos planos de saúde. Isso também é um exemplo concreto pra sua conclusão. O sistema econômico aceita pagar um pouco mais para os clientes que vão atender as consultas dos que pagam mais pelo plano de saúde, dos clientes preferenciais, dos clientes ricos. Se eles não terceirizam o da cúpula é porque eles sabem que a terceirização é sinônimo de serviço modesto, de rotatividade, de difícil qualificação, de difícil comprometimento. (Participante: MT1).

Não se duvida que a terceirização da atividade de telemarketing pelas empresas de telefonia buscava não a especialização e a qualificação do atendimento, mas sim o barateamento dos custos empresariais, até mesmo terceirizando serviços essencialmente ligados à atividade-fim. Ainda que o sindicato representante das operadoras de telefonia sustente que os serviços terceirizados, como os de telemarketing, proporcionam uma maior eficiência no atendimento dos clientes, fortalecendo o mercado, a competitividade e a geração de empregos, e o Sindicato Paulista das Empresas de Telemarketing, Marketing Direto e Conexões aponte um eventual surto de desemprego após a recente decisão do Tribunal Superior do Trabalho ${ }^{335}$, jamais se deve cogitar a supremacia dos interesses econômicos aos direitos fundamentais, dentre eles ao trabalho adequado, à saúde e à dignidade.

\footnotetext{
335 TRIBUNA DO NORTE. Terceirização de call center das teles é ilegal, diz TST. Natal, Economia, 10 nov. 2012. Disponível em: <http://tribunadonorte.com.br/noticia/terceirizacao-de-call-center-das-teles-e-ilegal-diztst/236293>. Acesso em: 12 nov. 2012.
} 


\subsection{As novas regras para o Serviço de Atendimento ao Consumidor versus Anexo II da Norma Regulamentadora $\mathrm{n}^{\circ}$ 17: antinomias}

O telemarketing expandiu-se no Brasil como um dos principais mecanismos de harmonização da relação consumerista para viabilizar os objetivos da Política Nacional das Reações de Consumo previstos no art. $4^{\circ}$, incisos III e IV, do Código de Defesa do Consumidor. No entanto, as expectativas quanto à efetividade desse mecanismo não se concretizaram, pois o contexto de telemarketing conquistou sem demora a insatisfação de consumidores e trabalhadores, conforme já exposto nas linhas pregressas.

Em resposta à denunciada precarização dos atendimentos e das condições de trabalho no setor de telemarketing, entre 2007 e 2008 passaram a viger dois dispositivos normativos: o Decreto $\mathrm{n}^{\circ}$ 6.523, de 31 de julho de 2008 - que fixou normas gerais sobre o Serviço de Atendimento ao Consumidor (SAC) - e o Anexo II da NR 17, do Ministério do Trabalho e Emprego - que estabeleceu parâmetros para a adaptação das condições de trabalho às características psicofisiológicas dos trabalhadores, sendo aplicável, conforme reforça Homero Batista Mateus da Silva, tanto a empresas do setor como para aquelas que se utilizam do telemarketing como mero apoio aos negócios ${ }^{336}$.

Colidentes entre si, esses dois dispositivos exerceram incontestável impacto no meio ambiente do trabalho, sobretudo na organização e nas condições laborais, em razão da necessidade de reestruturação do processo produtivo inerente a essas normas.

Em vigência desde $1^{\circ}$ de dezembro de 2008, o Decreto $n^{\circ} 6.523$, de 31 de julho de 2008, instituiu em seu artigo $1^{\circ}$ a observância dos direitos básicos para a obtenção de informações adequadas e claras sobre os serviços prestados e a proteção contra práticas abusivas ou ilegais. Dentre outras disposições, como a inadmissibilidade de transferência de ligações em caso de reclamação e cancelamento de serviço, instituiu ainda o prazo máximo de cinco dias úteis para a solução das reclamações (artigo 17, caput) e a clareza e a objetividade da resposta da demanda do consumidor (artigo 17, parágrafo $2^{\circ}$ ).

Foi a resposta do Estado à queixa dos consumidores sobre a baixa qualidade dos serviços prestados pelo setor de telemarketing, que se distanciava cada vez mais da sua natureza de mecanismo alternativo de solução de conflitos de consumo. Atendimento

\footnotetext{
336 SILVA, Homero Batista Mateus da. Curso de Direito do Trabalho aplicado: segurança e medicina do trabalho, trabalho da mulher e do menor. v. 3. Rio de Janeiro: Elsevier, 2009.
} 
precário, falta de autonomia dos teleoperadores para tomada de decisões, dificuldade no cancelamento de serviços, ausência de informações claras e precisas sobre produtos e serviços e maus tratos pelos teleoperadores são algumas justificativas da insatisfação dos consumidores que levaram à regulamentação do atendimento.

Conquanto, a disposição mais aguardada pelos consumidores foi definida somente mais tarde, através da Portaria $\mathrm{n}^{\mathrm{o}} 2.014$, de 13 de outubro de 2008, que limitou a sessenta segundos o tempo máximo de espera na ligação para contato direito com o teleoperador. Embora existisse expectativas de que essa providência repercutiria na humanização do atendimento e elevasse as contratações para atender ao aumento da demanda, a princípio, os impactos econômicos na receita das empresas de telemarketing frearam a abertura de novos postos de trabalho, intensificando ainda mais o ritmo da atividade.

Diante desse paradoxo, o Decreto $\mathrm{n}^{\circ}$ 6.523/08, ao instituir novas regras ao Serviço de Atendimento ao Consumidor para harmonizar a relação de consumo, seguiu na contramão do Anexo II da NR 17, cujo dispositivo há havia estabelecido em 2007 parâmetros mínimos para o trabalho em atividades de teleatendimento/telemarketing, incluindo a desaceleração do ritmo de trabalho para proporcionar um máximo de conforto, segurança e saúde aos trabalhadores do setor.

Enquanto o Decreto $n^{\circ}$ 6.523/2008 impôs tempo máximo para a duração da transferência de ligações e de solução para as reclamações, sem prejuízo do dever de objetividade e clareza das informações, o Anexo II da NR 17, na seção "Organização do Trabalho", estabeleceu o aumento de pausas fora do posto de trabalho (item 5.4.1), a proibição de aceleração do trabalho e da adoção de mecanismos de monitoramento da produtividade, como por exemplo, mensagens nos monitores de vídeo, sinais luminosos, sonoros ou indicações do tempo utilizado nas ligações ou de fila de espera de clientes (item 5.9).

Em síntese, ao mesmo passo que o Decreto $n^{\circ}$ 6.523/2008 propunha a aceleração do ritmo da atividade para atender os interesses consumeristas, o Anexo II da NR 17 instituiu parâmetros para a desaceleração, visando aos interesses dos trabalhadores do setor.

Não se duvida que os dois dispositivos traziam consigo a expectativa do aumento das posições de trabalho nas centrais de teleatendimento para não gerar sobrecarga habitual ao 
trabalhador, conforme mesmo preleciona o Anexo II da NR $17^{337}$. Porém, como já visto no subcapítulo anterior, entre 2008 e 2009 houve diminuição de postos de trabalho no setor, cujo fenômeno contribuiu para a precarização do trabalho em telemarketing, elevando os índices de doenças ocupacionais e afastamento pela sobrecarga de trabalho.

Evidente que não basta reduzir o tempo do atendimento e exigir dos teleoperadores um atendimento de qualidade, se não houver investimentos, novas contratações e fiscalização no setor de telemarketing, para equacionar os interesses dos consumidores e dos trabalhadores. E é justamente essa desarticulação que favorece a intensificação do ritmo de trabalho e das formas de exploração da atividade, que refletem na má prestação de serviços, desencadeando um relacionamento intolerante, tendente a influir no meio ambiente do trabalho e a comprometer seu equilíbrio. Isso porque quem faz a interface entre o fornecedor e o consumidor são os teleoperadores. São eles os destinatários tanto das cobranças de metas e resultados pelos fornecedores de produtos e serviços como das exigências dos consumidores, muitas vezes exaltados e frustrados pelo descumprimento de seus direitos e garantias.

É por isso que, de acordo com o sindicato da categoria em São Paulo, “depressão e estresse são sintomas que se apresentam cada vez com mais frequência em operadores de telemarketing”, causados, inclusive, pela forte cobrança de metas, atitudes grosseiras do público, repetição à exaustão do mesmo script e brincadeiras desagradáveis dos superiores hierárquicos ${ }^{338}$.

A ausência de autonomia desses trabalhadores, limados da participação intelectual e subjetiva no processo produtivo, também favorece o quadro de estresse ${ }^{339}$, embora determine o item 5.14 do Anexo II da NR 17 o dever de instituição de diretrizes claras quanto às ordens, à autonomia para a solução de problemas, à autorização para transferência de chamadas e às consultas a colegas e supervisores.

\footnotetext{
${ }^{337}$ 5.2. O contingente de operadores deve ser dimensionado às demandas da produção no sentido de não gerar sobrecarga habitual ao trabalhador; 5.3. O contingente de operadores em cada estabelecimento deve ser suficiente para garantir que todos possam usufruir as pausas e intervalos previstos neste Anexo.

${ }^{338}$ RIBEIRO, Silvia Basílio. Telemarketing enfrenta crise de saúde. Folha de São Paulo, São Paulo, 14 mar. 2004, Caderno Ilustrada. p. E2.

339 SILVA, Airton Marinho da. A regulamentação das condições de trabalho no setor de teleatendimento no Brasil: necessidades e desafios. 2004. 129 f. Dissertação (Mestrado em Saúde Pública) - Faculdade de Medicina, Universidade Federal de Minas Gerais, Belo Horizonte, 2004.
} 
Daí porque Ada Ávila Assunção e Airton Marino da Silva concluem que é quase inevitável a presença de estresse, tensão psicológica, ansiedade, depressão e fadiga em teleoperadores $^{340}$. Em outro estudo, $82 \%$ dos 34 operadores entrevistados manifestaram sintomas de estresse, como ansiedade, depressão, angústia, isolamento social, dores musculares, de cabeça e de estômago ${ }^{341}$.

Ainda em tempo, o Anexo II da NR 17 reconheceu o risco de esgotamento psicológico no desempenho da atividade, em decorrência do trato com superiores hierárquicos e clientes, dando um importante passo para o reconhecimento da causalidade ou concausalidade entre o trabalho e o infortúnio psicológico. Previu em seu item 5.4.5 a garantia de pausas no trabalho imediatamente após a ocorrência de ameaças, abusos verbais e agressões por parte dos consumidores, para que os teleoperadores socializassem conflitos e dificuldades com supervisores, profissionais de saúde ocupacional ou outros teleoperadores.

Para fins de elaboração de programas preventivos, o referido dispositivo proibiu a utilização de instrumentos de avaliação, tendentes a causar impactos sobre a saúde dos teleoperadores, e a aceleração do ritmo de trabalho em horários de maior demanda (no item 5.10, alíneas “c" e “d”); em descompasso, o Decreto $n^{\circ}$ 6.523/08 impôs a agilidade de atendimento e de solução dos problemas apresentados pelos consumidores. Deve-se, ainda, interpretar esse antagonismo levando-se em consideração a queda das contratações nos últimos anos, que tornou inviável a agilidade de atendimento sem prejuízo da qualidade e da saúde e bem-estar dos trabalhadores.

Diante dessa radiografia, evidente o conflito entre interesses consumeristas e interesses dos trabalhadores que impôs, por força do capital, alguns obstáculos à política de harmonização da relação de trabalho em telemarketing. Evidente, ainda, a interdependência do equilíbrio do meio ambiente do trabalho com outros contextos ambientais, no caso, o mercado de consumo, que pode ser vista, na perspectiva da abordagem ecológica proposta por Urie Bronfenbrenner, como a influência do exossistema no microssistema e vice-versa (vide Figura 1). Também é possível observar a influência do sistema econômico, que compõe o

\footnotetext{
${ }^{340}$ SILVA, Airton Marinho da; ASSUNÇÃO, Ada Ávila. Negociações sociais para melhoria das condições de trabalho no setor de teleatendimento: o descompasso entre a posição das empresas e a realidade do trabalho. Interface, Botucatu, v. 9, n. 18, p. 553-570, fev. 2005.

341 ODA, Carla. Operadores de telemarketing: stress, autonomia, somatização e dores em pescoço e ombros. 138 f. Dissertação (Mestrado em Psicologia)-Instituto de Psicologia, Universidade de São Paulo, São Paulo, 2003.
} 
macrossistema, no meio ambiente do trabalho em telemarketing, que é o microssistema focalizado neste estudo (vide Figura 3).

Nessa perspectiva, as normas que dispõem sobre a prestação de serviços, tanto na seara trabalhista como consumerista, carecem de medidas de integração e harmonização, sob pena de comprometer direitos fundamentais equilibrado garantidos a todo cidadão, como o direito ao trabalho digno e adequado, à saúde, à informação e ao meio ambiente do trabalho. Todavia, não se conferiu esse zelo no contexto de telemarketing.

Pouco após a aprovação do Decreto nº 6.523/08, o Ministério da Justiça já comemorava seus impactos na vida de milhares de consumidores, em razão da adaptação de cerca de $50 \%$ das empresas do setor às novas regras ${ }^{342}$. Contudo, por apresentar pontos de tensão com as políticas de saúde e qualidade de vida direcionadas aos trabalhadores do setor, contribuindo para a precarização das condições de trabalho, lamentaram os sindicatos o fato das autoridades terem elaborado o decreto e as portarias que estabeleceram as novas regras para as centrais de atendimento, sem consulta aos trabalhadores, mas apenas às empregadoras, consumidores e aos órgãos de proteção consumerista.

A elaboração do Decreto $n^{\circ} 6.523 / 08$ e das portarias que estabeleceram as novas regras para as centrais de atendimento sem a participação dos sindicatos profissionais comprometeu a democracia participativa no processo de produção dessa norma por não incluir todos os atores não estatais, sendo esse um dos pontos que explicam o conflito entre o Decreto e o Anexo II da NR 17. E como já dito antes, se inexistente o diálogo entre todos os atores não estatais protagonistas daquele contexto, é certo que surgirão dificuldades para se efetivar o direito contido na norma, até porque não foram ouvidos todos aqueles que participam e vivenciam aquele contexto, que melhor conhecem os riscos, as necessidades e as formas de efetivação das garantias e dos direitos versados na norma.

Até mesmo em um breve exame comparativo entre a importância dada ao Decreto $\mathrm{n}^{\mathrm{o}}$ 6.523/08 e ao Anexo II da NR 17 pelos veículos da imprensa, observou-se que mais se falou sobre o decreto. Falou-se muito sobre as novas regras para o telemarketing e sobre a sua fiscalização e pouco se falou sobre os impactos e o cumprimento das medidas instituídas pelo Anexo II da NR 17, que estabeleceu parâmetros para a adaptação das condições de trabalho às

\footnotetext{
${ }^{342}$ PEDUZZI, Pedro. Metade das empresas já se adaptou à Lei do Call Center, diz ministro da Justiça. Agência Brasil, Brasília, 19 dez. 2008. Disponível em: <http://www.agenciabrasil.gov.br/noticias/2008/12/19/ materia.2008-12-19.4088438939/view>. Acesso em: 3 nov. 2009.
} 
características psicofisiológicas dos teleoperadores, cuja discussão se restringiu ao cenário jurídico.

Desde a aprovação do Decreto $n^{\circ} 6.523 / 08$, somente em jornais foram publicadas diversas matérias sobre a fiscalização e a satisfação dos consumidores com as novas regras para o telemarketing ${ }^{343}$. No entanto, nesse mesmo período pouco se falou sobre as condições de trabalho dos teleoperadores e sobre os impactos do Anexo II da NR 17 do mundo do trabalho; pouco se sabe se as empresas do setor se adaptaram ao conteúdo dessa norma regulamentar.

Outra resistência enfrentada pela Portaria $n^{\circ} 9$ do Ministério do Trabalho e Emprego, que instituiu o Anexo II da NR 17, diz respeito à constitucionalidade dos seguintes itens: 5.3 - que fixou o tempo máximo de trabalho em efetiva atividade de telemarketing em 6 (seis) horas diárias, nele incluídas as pausas, sem prejuízo da remuneração, afastando a regra insculpida no artigo 58 da Consolidação das Leis do Trabalho; 5.4.1 - que instituiu duas pausas especiais de 10 minutos cada, após os primeiros e antes dos últimos 60 (sessenta) minutos de trabalho; 5.4.2 - que aumentou de 15 para 20 minutos o intervalo para repouso e alimentação - e 5.4.3 - que instituiu pausa de descanso de 10 minutos para jornada de trabalho de até 4 horas, a despeito do prescrito no art. 71 , parágrafo $1^{\circ}$, da Consolidação das Leis do Trabalho.

Tratava-se de uma discussão bastante recorrente na Justiça do Trabalho, dividindo opiniões motivadas por interesses econômicos, que sustentavam o encarecimento da mão de obra sujeita a uma jornada reduzida sem dedução das pausas previstas em desconformidade com a Consolidação das Leis do Trabalho, e por interesses sociais, que defendiam a redução

\footnotetext{
34319 dez. 2008 - 72 empresas são intimadas por call center (Folha de São Paulo - Caderno Cotidiano); 02 fev. 2009 - Procon detecta demora dos SACs para resolver queixas (Folha Online); 03 fev. 2009 - Atendimento pela internet será regulamentado (O Estado de São Paulo - Caderno Economia); 04 fev. 2009 - Governo multa empresa em R \$ 3 mi por descumprir regras de call Center (Correio Braziliense - Caderno Economia); 11 mar. 2009 - SACs descumprem regras (Jornal da Tarde - Economia); 31 mar. 2009 - Em 4 dias, 26 mil dizem não a telemarketing (Folha de São Paulo - Caderno Cotidiano); 30 jul. 2009 - Falha em call center rende multa de R\$ 10 milhões a empresas, diz Procon-SP (Folha Online); 21 ago. 2009 - Consumidor pode registrar queixa contra call center a partir de hoje (Correio Braziliense - Economia); 02 set. 2009 - Cliente mal atendido pode se desligar sem multa de teles, diz Ministério da Justiça (Correio Braziliense - Economia); 04 ago. 2010 - Cancelar serviço: queixa de consumidor (Jornal da Tarde - Economia); 30 ago. 2010 - Bloqueio de telemarketing ainda é ignorado (Jornal da Tarde - Economia); 01 fev. 2011 - Após dois anos de vigência da lei, o cidadão ainda é vítima dos SACs (Correio Braziliense - Economia); 28 fev. 2011 - Empresas não pagam por problema em call center (Folha de São Paulo - Mercado); 06 abr. 2011 - Lei 'antitelemarketing' completa 2 anos em baixa (Jornal da Tarde - Economia); 09 maio 2011 - Consumidor perde dinheiro com o SAC (Jornal da Tarde - Economia).
} 
da jornada de trabalho e a ampliação das pausas, por se tratar de uma atividade penosa, tendente ao adoecimento dos trabalhadores.

Para os defensores da tese da inconstitucionalidade da Portaria $\mathrm{n}^{\circ}$ 9, a fixação da jornada máxima de 6 horas apenas seria possível através de lei federal, da jurisprudência ou de negociação coletiva, sob pena de violação do Princípio da Legalidade, irradiado do artigo $5^{\circ}$, inciso II, da Constituição Federal. Alegavam a evasão do campo material das portarias, delimitado no artigo 84, inciso IV, da Constituição Federal ${ }^{344}$, haja vista que é defeso a essa espécie normativa inovar no mundo jurídico, sendo-lhe permitido apenas buscar a execução da lei. A essa corrente se filia Ricardo Georges Affonso Miguel:

Nos termos do art. 87, II da Constituição da República, compete ao Ministro de Estado "expedir instruções para a execução das leis, decretos e regulamentos". Logo, forçoso concluir que a função das normas regulamentadoras editadas pelo Ministério do Trabalho é, na verdade, instruir a execução das leis, decretos e regulamentos, e jamais legislar acerca de estipulação da duração do trabalho, criando intervalo intrajornada não insculpido no art. 71 da CLT, sob pena de afronta ao princípio da competência legislativa, arts. $22, \mathrm{I} \mathrm{c} / \mathrm{c} 48 \mathrm{da} \mathrm{CRFB}$, bem como à observância da legalidade estrita, já que norma regulamentadora não é lei em sentido formal. Mais ainda. Haveria violação do princípio da separação dos poderes do art. $2^{\circ}$ da CRFB.

No mesmo sentido deve ser a interpretação do disposto nos arts. 155 e 200 da CLT, até porque o inciso I do art. 155 faz referência aos limites da competência do órgão fiscalizador. A interpretação a se fazer do cotejo desses dispositivos com a Constituição é a de que o legislador celetista houve por bem conceder ao Poder Executivo a competência para estipular meios e modos para uma execução melhor e mais segura do trabalho. Porém, em momento algum atribuiu competência legislativa para, frise-se, legislar sobre duração do trabalho, jornada do trabalho, o que ocorreu manifestamente no item 5.4.1 do anexo II da NR-17 ao estipular a necessidade de intervalos durante a jornada do teleoperador.

Destarte, pacificada pela súmula 346 do TST a inaplicabilidade da jornada reduzida dos telefonistas aos operadores de teleatendimento, devemos entender também pela inaplicabilidade dos intervalos previstos no anexo II da NR-17 e no art. 72 da CLT, pois os intervalos aos quais fazem jus são os mesmos para os trabalhadores em geral, quais sejam, os insculpidos no art. 71 da CLT. Saliente-se, ainda, que a estipulação de jornada reduzida na norma administrativa em comento encontra os mesmos óbices acima esposados. $^{345}$

\footnotetext{
${ }^{344}$ Art. 84. Compete privativamente ao Presidente da República: (...) IV - sancionar, promulgar e fazer publicar as leis, bem como expedir decretos e regulamentos para sua fiel execução.

${ }^{345}$ MIGUEL, Ricardo Georges Affonso. A inaplicabilidade de jornada reduzida e intervalos específicos ao operador de teleatendimento. Revista do Tribunal Regional do Trabalho da $1^{a}$ Região, Rio de Janeiro, v. 21, n. 48, p. 97-99, jul./dez. 2010.
} 
Por outro lado, para os defensores da tese da constitucionalidade, a Portaria $\mathrm{n}^{\circ} 9$ decorre do uso das atribuições legais da Secretaria de Inspeção do Trabalho e do Diretor do Departamento de Segurança e Saúde no Trabalho, nos termos do artigo 200 da Consolidação das Leis do Trabalho ${ }^{346}$. Afirmam que o Ministério do Trabalho e Emprego é competente para estabelecer disposições complementares às normas do capítulo celetista que trata da segurança e medicina do trabalho, nos termos do artigo $1^{\circ}$ da Portaria $n^{\circ} 3.214 / 78$, cuja medida aprova as normas regulamentares do Capítulo V, Título II, da Consolidação das Leis do Trabalho. Nesse espeque, pontua Homero Batista Mateus da Silva:

No caso da segurança e medicina do trabalho, entretanto, entendeu-se necessário delegar a regulamentação para um órgão ainda mais técnico e mais aprofundado em seu mister, que vem a ser o Ministério do Trabalho e, dentro de seu cronograma, por intermédio de suas Secretarias e Departamentos especializados. ${ }^{347}$

José Affonso Dallegrave Neto também entende pela constitucionalidade nos seguintes termos:

Nessa esteira axiológica, não resta dúvidas de que a Carta Constitucional de 1988 recepcionou a Portaria $\mathrm{n}^{\circ}$ 3.214/78 do MTE (Ministério do Trabalho e Emprego) e suas inúmeras Normas Regulamentares (NRs). Ao julgador cabe efetivar estas regras de prevenção, seja com vista a contribuir para a redução dos altos índices de acidentes e doenças do trabalho, seja para prestigiar a interpretação sistêmica, conforme a Constituição Federal.

Não se duvide da força normativa dessas NRs pelo simples fato de elas serem Portarias do MTE e, portanto, meros atos regulamentares do Poder Executivo. De uma adequada interpretação do sistema jurídico, verifica-se que tanto a lei (art. 200 da CLT) quanto a Constituição Federal (art. $7^{\circ}$, XXII) inspiram, referendam e impulsionam as aludidas NRs, conferindo-lhes indubitável e autêntica normatividade.

Exemplo de sua plena aplicabilidade ocorre nos enquadramentos dos pedidos de insalubridade e de periculosidade nos termos da NR-15 e NR-16, respectivamente. Ora, durante décadas a Justiça do Trabalho vem aplicando com acerto as Normas Regulamentadoras e nunca ninguém obteve êxito na alegação de "ilegalidade" ou "ausência de força normativa".

\footnotetext{
${ }^{346}$ Art. 200. Cabe ao Ministério do Trabalho estabelecer disposições complementares às normas de que se trata este Capítulo, tendo em vista as peculiaridades de cada atividade ou setor de trabalho, especialmente sobre: (...) VIII - colaborar na proteção do meio ambiente, nele compreendido o do trabalho.

347 SILVA, Homero Batista Mateus da. Curso de Direito do Trabalho aplicado: segurança e medicina do trabalho, trabalho da mulher e do menor. v. 3. Rio de Janeiro: Elsevier, 2009. p. 3.
} 
O próprio STF já pacificou este entendimento ao editar a Súmula no 194: “é competente o MTE para especificações das atividades insalubres". ${ }^{348}$

Entendemos pela constitucionalidade do Anexo II da NR 17, até porque, além dos fundamentos supramencionados, ao colaborar com a proteção do meio ambiente do trabalho e considerar seus impactos na saúde e qualidade de vida dos teleoperadores, a Portaria $n^{\circ} 9$ se enquadra na previsão constitucional taxativa do art. 200, especificamente em seu inciso VIII.

Ademais, o objetivo do Ministério do Trabalho e Emprego era mitigar a penosidade da atividade de telemarketing através do aumento de pausas e da diminuição da exposição dos teleoperadores aos fatores de riscos por meio da redução para a jornada de trabalho, matéria que se encontra na competência do Direito do Trabalho, mais especificamente do órgão ministerial do trabalho, conforme esclareceu um dos participantes deste estudo:

Não é inconstitucional. Eu gostaria de fundamentar. Analisando exclusivamente do ponto de vista da fixação da jornada, só por esse lado, chamaria atenção porque a fixação da jornada é assunto concernente ao Direito do Trabalho. Direito do Trabalho é uma matéria de competência exclusiva da União, segundo o artigo 22 da Constituição, inciso I. Não se discute que seja competência exclusiva da União. Quando se fala competência da União, é competência do Congresso Nacional. (...) Só que a competência analisada de um contexto mais amplo, e provavelmente os detalhes fogem a uma análise mais superficial. (...) Na CLT, a grande preocupação do trabalho penoso e na Constituição de 88 o trabalho penoso está como uma promessa, que em 22 anos não bastaram para se concretizar. Então eu vejo com bons olhos que algumas atenuantes sejam feitas. Se a gente analisar com mais profundidade, a gente vai encontrar muito mais do que o telemarketing. O telemarketing é a bola da vez, provavelmente porque emprega um número expressivo de pessoas, envolve o capital internacional, mas isso já foi feito com o aeroviário, em 1962, com o trabalho em céu aberto, carga de 6 horas. (...) Então, analisando do ponto de vista da segurança do trabalho, a ergonomia a CLT delega para o Poder Executivo incontáveis vezes essa disciplina, daí porque não haveria uma colisão, desde que interprete a jornada dentro de um pacote de medidas. Provavelmente, o Anexo seria infeliz se ele tivesse um único dispositivo: jornada amanhã passa a ser de 6 horas. E não é! (Participante MT1).

\footnotetext{
${ }^{348}$ DALLEGRAVE NETO, José Affonso. A força vinculante das Normas Regulamentadoras do Ministério do Trabalho e Emprego (NRs do MTE) e o Anexo II da NR-17. Revista do Tribunal Regional do Trabalho da $1^{a}$ Região, Rio de Janeiro, v. 21, n. 48, p. 119-123, jul./dez. 2010.
} 
Nesse encalço, não se duvida que, ao instituir o Anexo II da NR 17, a finalidade do Ministério do Trabalho e Emprego era a tutela da saúde dos trabalhadores do setor, visando à redução dos altos índices de acidentes e doenças do trabalho, conforme anunciado em seu item 1: "O presente Anexo estabelece parâmetros mínimos para o trabalho em atividades de teleatendimento/telemarketing nas diversas modalidades desse serviço, de modo a proporcionar um máximo de conforto, segurança, saúde e desempenho eficiente”. A redução da jornada de trabalho, a instituição de pausas especiais e a ampliação do intervalo para repouso e alimentação foram "medidas-meio" e não a finalidade.

Portanto, a constitucionalidade do Anexo II da NR 17 é referendada pela integração dos artigos 155, 200 e $7^{\circ}$, inciso XXII, da Constituição Federal, que garantem autêntica e inquestionável normatividade aos seus dispositivos. É o que se denomina de competência normativa secundária ou delegação normativa, ou seja, a atribuição de uma função típica do Poder Legislativo ao Executivo para instituir normas complementares àquelas derivadas da fonte legislativa ${ }^{349}$.

O cancelamento da Orientação Jurisprudencial no 237 da Seção Especializada de Dissídios Individuais 1 pelo Pleno do Tribunal Superior do Trabalho, que reconheceu a penosidade da atividade de telemarketing e estendeu aos teleoperadores a jornada de seis horas prevista no artigo 227 da Consolidação das Leis do Trabalho, esvaziou definitivamente a tese dos defensores da inconstitucionalidade do Anexo II da NR 17.

Por fim, de tudo se extrai que, além da intensificação das formas de exploração do trabalho em telemarketing, os teleoperadores ainda se encontram esmagados pelos interesses econômicos do modelo capitalista, representados, de um lado, por consumidores reivindicando a qualidade e agilidade da prestação, cujos interesses foram positivados através do Decreto $\mathrm{n}^{\mathrm{o}}$ 6.523/08; do outro lado, por empregadores sedentos por resultados, sem qualquer preocupação com os aspectos organizacionais do meio ambiente do trabalho e seus impactos na saúde e qualidade de vida no trabalho, que preferem questionar a constitucionalidade do Anexo II da NR 17 a efetivá-la para garantir um meio ambiente do trabalho equilibrado aos teleoperadores.

Por essas e outras razões, o telemarketing - como um dos serviços mais terceirizados na atualidade - está inserido em uma “conjuntura recente de globalização, novas

\footnotetext{
${ }^{349}$ JUSTEN FILHO, Marçal. Curso de direito administrativo. 2. ed. São Paulo: Saraiva, 2006. p. 169.
} 
tecnologias e privatização da telefonia onde predomina a força econômica" ${ }^{350}$. É através da terceirização que as empresas de telemarketing viabilizam sua competitividade no mercado global, desmontando a estrutura tradicional das empresas tomadores do serviço e deixando de se responsabilizar pela totalidade do processo produtivo ${ }^{351}$, inclusive pelas condições em que o trabalho é desenvolvido. Eis, portanto, a forte influência do sistema econômico, como um dos elementos integrantes do macrossistema, no meio ambiente do trabalho em telemarketing.

Não se sugere nestas linhas uma sobreposição de hipossuficiência entre consumidores e teleoperadores, que evidentemente possuem interesses próprios. Não se quer dizer que os interesses dos teleoperadores devem sufocar os interesses consumeristas. Defende-se sim a necessidade da harmonização dos interesses dos trabalhadores e consumidores, através de políticas públicas coordenadas, para que as propostas de equilíbrio da relação de consumo não onerem ainda mais a relação de emprego através de medidas que envolvam os dois atores sociais, mas que sejam construídas apenas com a participação de um deles.

Cabe ao Direito do Trabalho a garantia a todos os cidadãos do acesso a um trabalho digno, através de uma "política de promoção dos direitos humanos fundamentais inspirada pelo artigo $1^{\circ}$ de nossa Constituição, que aponta a dignidade da pessoa humana como um dos fundamentos da República"352.

\subsubsection{A relação pessoa-ambiente e o Anexo II da Norma Regulamentadora $\mathrm{n}^{\circ} 17$}

O Anexo II da NR 17 deu um grande passo no contexto jurídico ao considerar a relação pessoa-ambiente enfocada neste estudo para a instituição de parâmetros visando à adaptação das condições de trabalho às características psicofisiológicas dos trabalhadores. Não se ateve apenas aos aspectos físicos do meio ambiente do trabalho em telemarketing, mas

\footnotetext{
${ }^{350}$ SILVA, Airton Marinho da. A regulamentação das condições de trabalho no setor de teleatendimento no Brasil: necessidades e desafios. 2004. 129 f. Dissertação (Mestrado em Saúde Pública)- Faculdade de Medicina, Universidade Federal de Minas Gerais, Belo Horizonte, 2004. p. 10.

${ }^{351}$ MANNRICH, Nelson. Terceirização: luzes e sombras. In: MARTINS, Sergio Pinto; MESSA, Ana Flávia (Coord.). Empresa e Trabalho. Estudos em homenagem a Amador Paes de Almeida. São Paulo: Saraiva, 2010. $415 \mathrm{p}$.

${ }^{352}$ SILVA, Otavio Pinto e. Relações de trabalho e relações de consumo: o futuro da Justiça do Trabalho. Revista do Departamento de Direito do Trabalho e da Seguridade Social, São Paulo, v. 1, n. 1, p. 143-162, jan./jun. 2006.
} 
também considerou os fatores pessoais, constituídos pelos aspectos psicológicos e comportamentais, que também integram o locus laboral (vide Figura 2).

Nessa perspectiva, o Anexo II da NR 17 chancelou a inter-relação pessoaambiente, proposta neste estudo na forma do Princípio da Bidirecionalidade, trazendo grandes avanços para o campo da saúde do trabalhador. Não se ateve a discutir a saúde e segurança dos teleoperadores apenas sob a perspectiva da ergonomia, mas foi além ao considerar a influência da organização e das condições de trabalho na saúde e bem-estar dos teleoperadores, considerando que os infortúnios psicológicos são as preocupações do novo século.

No item 5.1.2.1, o aludido anexo considerou eventuais necessidade especiais da vida familiar dos trabalhadores com dependentes sob seus cuidados, incluindo os casos de amamentação, para a elaboração das escalas de trabalho e flexibilização para trocas de horários e utilização das pausas. Considerou, portanto, os impactos da rígida organização da atividade no bem-estar dos trabalhadores, humanizando mais essa relação de trabalho ao olhar para a influência do microssistema meio ambiente no trabalho no mesossistema lar e viceversa. A mesma interdependência é considerada no item 5.1 que prevê, com reserva aos serviços obrigatoriamente disponibilizados em todos os dias da semana, a elaboração da escalas com folgas aos domingos e feriados, para que o trabalhador usufrua do convívio familiar e de vida social, nela inclusa o direito ao lazer.

Os itens 5.4.1, 5.4.2 e 5.4.3 abordam as pausas e o intervalo obrigatório, cuja matéria causou um evidente desconforto para o empresariado do setor, que se viu obrigado a reorganizar a atividade em virtude da mudanças impostas. O item 5.4.1 acrescentou duas pausas de 10 minutos (alínea "b") a serem concedidas após os primeiros e antes dos últimos 60 (sessenta) minutos da jornada de trabalho (alínea “c”); o item 5.4.2 ampliou o intervalo obrigatório para repouso e alimentação previsto no parágrafo $1^{\circ}$ do artigo 71 da Consolidação das Leis do Trabalho, de 15 para 20 minutos; e o item 5.4.3 inovou ao estabelecer uma pausa de 10 minutos aos teleoperadores submetidos à jornada de trabalho de 4 horas, não assistidos pelo artigo 71 da Consolidação das Leis do Trabalho.

Deve-se observar que as pausas previstas nos itens 5.4.1 e 5.4.3 não possuem a mesma natureza jurídica do intervalo previsto no art. 71 , parágrafo $1^{\circ}$, da Consolidação das Leis do Trabalho, devendo ser consideradas como pausas especiais. Por isso, a questão tem 
enfrentado opiniões divergentes dos Tribunais acerca ao cabimento de horas extras quando não concedidas essas pausas.

Diante da natureza jurídica diversa, uma das correntes sustenta que é incabível a aplicação analógica do art. 71, parágrafo $2^{\circ}$, da Consolidação das Leis do Trabalho, não havendo que se falar em cabimento de horas extras quando não concedidas as pausas previstas no Anexo II da NR 17, conforme a seguir se observa: HORAS EXTRAS PAUSAS DE DESCANSO NO ATENDIMENTO DE
TELEMARKETING - INTERVALO INTRAJORNADA CONCESSÃO -
NÃO CABIMENTO DAS HORAS EXTRAS PLEITEADAS. Não há que
confundir pausa para descanso prevista na NR 17, com intervalo
intrajornada previsto no art. 71, $\S \mathbf{1}^{\mathbf{0}}$, da CLT, uma vez que a primeira
integra a jornada de trabalho e o segundo não, sendo indevidas as horas
extras pleiteadas, quando concedidas as respectivas pausas e intervalos.
DANO MORAL - NÂ COMPROVAÇÂO DE ATO ILÍCITO
PRATICADO PELA RECLAMADA - INDEFERIMENTO. A
responsabilidade civil do empregador pela indenização decorrente de dano
moral pressupõe a existência de três requisitos: a prática de ato ilícito ou
com abuso de direito; o dano propriamente dito (prejuízo material ou o
sofrimento moral) e o nexo causal entre o ato praticado pelo empregador ou
por seus prepostos e o dano sofrido pelo trabalhador. Sem a comprovação
desses requisitos, não há como se reconhecer o direito à indenização.
Recurso conhecido, mas desprovido. (TRT $7^{\text {a }}$ região. $1^{\text {a }}$ Turma. RO
0000021-402015070011. Relatora Dulcina de Holanda Palhano.
Publicação: $04 / 07 / 2012$ DEJT) - grifo nosso.

ATIVIDADES DE TELEATENDIMENTO E TELEMARKETING. INTERVALO PARA REPOUSO E ALIMENTAÇÃO. O disposto no art. $71, \S 2^{\circ}$, da CLT, que disciplina que os intervalos de descanso não serão computados na duração do trabalho, encontra-se em harmonia com a NR 17, Anexo II. Apenas as 2 (duas) pausas de 10 minutos, cada, devem ser concedidas de forma remunerada e incluídas na jornada de $\mathbf{6}$ horas. Não comprovando o autor a inobservância do regramento acima, a sentença deve ser mantida. PARTICIPAÇÃO NOS LUCROS E RESULTADOS. PAGAMENTO PROPORCIONAL AOS MESES TRABALHADOS. PRINCÍPIO DA ISONOMIA. Fere o princípio da isonomia instituir vantagem mediante acordo coletivo ou norma regulamentar que condiciona a percepção da parcela participação nos lucros e resultados ao fato de estar o contrato de trabalho em vigor na data prevista para a distribuição dos lucros. Inteligência da OJ n 390 da SDI-1 do TST. (TRT $7^{\text {a }}$ Região. $1^{\text {a }}$ Turma. RO 0001819-6120105070014. Relatora: Dulcina de Holanda Palhano. Publicação: 22/03/2012 DEJT) - grifo nosso.

Justificam, ainda, que o intervalo previsto no art. 71 , parágrafo $1^{\circ}$, da Consolidação das Leis do Trabalho não integram a jornada de trabalho, enquanto as pausas especiais instituídas pelo Anexo II da NR 17 integram e são remuneradas. Ocorre que a maioria das empresas do setor integram o intervalo obrigatório para repouso e alimentação à 
jornada de trabalho, afastando a justificativa em que se ampara os acórdãos supramencionados.

Não nos filiamos à corrente que veda a aplicação analógica do art. 71, parágrafo $2^{\circ}$, da Consolidação das Leis do Trabalho, porque além do fato acima apontado, admitir a inexistência de qualquer sanção pelo descumprimento dos itens 5.4.1 e 5.4.3 do Anexo II da NR 17 seria concluir que tal dispositivo foi construído à luz do modal deôntico permissivo e não do obrigatório, tornando facultativo seu cumprimento, o que viria a comprometer a efetividade dessa medida tão importante para atenuar a penosidade do trabalho em telemarketing. Ademais, basta uma breve análise hermenêutica dos itens 5.4.1 e 5.4.3, sob os métodos de interpretação gramatical e teleológico, para se concluir que o caráter obrigatório da norma, emanado do emprego do verbo "dever", conforme o entendimento jurisprudencial a seguir apresentado:

INTERVALOS. TELEMARKETING. NORMA REGULAMENTADORA. Considerando a atividade de telemarketing desempenhada pela reclamante, tem-se como cabível a concessão de duas pausas de 10 minutos, durante a jornada de trabalho, nos termos da NR 17 do Ministério do Trabalho e Emprego. No caso, as reclamadas não se desincumbiram do ônus de comprovar a real jornada de trabalho da reclamante, na forma do art. 74, § $2^{\circ}$, da CLT, presumindo-se verdadeira a jornada descrita na inicial, conforme estabelece a Súmula $n^{\circ} 338$ do TST. Assim, entende-se que, por uma aplicação analógica do art. $71, \S 4^{\circ}$ da CLT, o trabalho desempenhado durante o período destinado a pausas deve ser remunerado como trabalho extraordinário. Recurso provido. (TRT $4^{\mathrm{a}}$ Região. RO 000115402.2010.5.04.0023. Relator Francisco Rossal de Araújo. Julgamento: 17/05/2012) - grifo nosso.

Ainda sobre o item 5.4.1, a alínea "a" instituiu o dever de concessão das pausas fora do posto de trabalho, pois, de acordo com a casuística, até mesmo o intervalo para repouso e alimentação antes do Anexo II da NR 17 muitas vezes era cumprido na posição de atendimento. Assim sendo, o teleoperador não se desligava da atividade, comprometendo o efetivo alcance da finalidade da norma, que é a recomposição psicofísica do trabalhador.

Evidentemente, o cumprimento da exigência em comento requer bom senso do empregador. Cumprir as pausas fora do posto de trabalho não significa em qualquer lugar ou dependência do centro de atendimento, haja vista que os fatores ambientais influenciam na recomposição psicofísica do trabalhador. Dificilmente um teleoperador recobrará suas energias se usufruir da pausa em local inapropriado, como por exemplo em pé, nas ilhas ou 
em qualquer outro lugar o call center que o mantenha direta ou indiretamente ligado a atividade. Deve ser um ambiente que permita, por exemplo, relaxamento, interação entre teleoperadores, contato com assuntos diversos (assistir televisão, acessar internet, etc.) ou atividades físicas conforme faculta item 5.6 do Anexo II da NR 17.

Contudo, a interação entre teleoperadores jamais foi estimulada no contexto de telemarketing, exceto para fins de competição visando ao aumento da produtividade. Prova disso é o próprio arranjo espacial do ambiente de telemarketing, que separa os teleoperados em baias, impedindo que um teleoperador interaja com os outros lotados nos postos de atendimentos à sua frente, atrás e aos lados. Além disso, há orientação para que se mantenham sentados durante a jornada de trabalho, sendo essa uma prática perversa a medida que ao teleoperador nem mesmo é possível se distanciar do posto de trabalho, onde se encontra conectado durante toda a jornada pelo fio do headset. Por isto, o item 5.8 do Anexo II da NR 17 instituiu o dever de que os empregadores do setor permitam a alternância de postura pelo trabalhador de acordo com sua conveniência e necessidade.

Os itens 5.4 .5 e 5.9 abordam dois aspectos de suma importância na saúde dos trabalhadores em telemarketing, cuja perspectiva interacional tem sido pouco abordada pelo Direito do Trabalho, favorecendo a impropriedade dos peritos judiciais e previdenciários no exame do nexo causal, direito e indireto, entre o trabalho e os infortúnios psicológicos.

O item 5.4.5 garante pausas imediatas aos teleoperadores após chamadas em que houver ocorrido ameaças, abusos verbais, agressões ou que tenham sido especialmente desgastantes, o que é comum nessa forma de trabalho, conforme já exposto. Visa possibilitar à socialização de conflitos e dificuldades com outros colegas, supervisores ou profissionais de saúde ocupacional devidamente capacitados para a promover o acolhimento desse teleoperador. Note-se que esse item reconhece que os fatores pessoais (psicológicos e comportamentais) integram o meio ambiente do trabalho (vide Figura 2) e, por sua vez, influenciam em seu equilíbrio e na saúde dos trabalhadores que vivenciam aquele contexto ambiental, chancelando a inter-relação pessoa-ambiente consubstanciada no Princípio da Bidirecionalidade proposto nesse estudo. Reconhece, ainda, a interdependência entre contextos ambientais, a partir do momento em que considera que reiteradas agressões verbais ou ameaças proferidas por consumidores insatisfeitos podem comprometer a saúde dos teleoperadores; significa dizer, na perspectiva da Figura 1, que existe interdependência entre o mesossistema mercado de consumo e o microssistema meio ambiente do trabalho. 
Logo, fica ainda mais claro que estresse, depressão, síndrome do pânico e do esgotamento nervoso são infortúnios que podem sim ser desencadeados ou agravados pela atividade laboral.

Por sua vez, o item 5.16 do Anexo II da NR 17 garantiu ao teleoperador o direito de ocultar seu sobrenome nos diálogos com consumidores, visando resguardar sua privacidade e segurança pessoal. Esse inusitado dispositivo não apenas reconheceu a interdependência entre o meio ambiente do trabalho e contextos externos (mercado de consumo), como também considerou os impactos na saúde dos teleoperadores dos atritos com consumidores, por vezes finalizados com ameaças e agressões verbais, como bem ventila o item 5.4.5.

No mesmo compasso, o item 5.9 proibiu a utilização ostensiva de mecanismos de monitoramento da produtividade (como por exemplo, mensagens nos monitores de vídeo, sinais luminosos, cromáticos, sonoros, ou indicações do tempo utilizado nas ligações ou de filas de clientes em espera), usualmente adotados pelas empresas do setor para acelerar o trabalho. Permitiu a utilização desses mecanismos apenas para a consulta pelos teleoperadores, quando e se quiserem. Extrai-se dessa regra a permissão da utilização de mecanismos de monitoramento apenas para medir a produtividade e não para acelerar o ritmo da atividade, mitigando com a vedação dessa prática a penosidade do telemarketing, marcado por fortes cobranças e rígida organização. Quanto aos períodos de alta demanda, previu o item 5.2.1 o dever das empresas do setor equacionarem o contingente de teleoperadores em cada estabelecimento à demanda, para garantir que todos possam usufruir as pausas e intervalos previstos, não havendo que se falar em sobrecarga em virtude de imprevistos.

Por meio desses itens, o Anexo II da NR 17 chancelou a influência dos aspectos organizacionais, que integram o meio ambiente do trabalho (vide Figura 2), na saúde do trabalhador, ao reconhecer que painéis informativos sobre o número de ligações em espera, atendidas e abandonadas, bem como mensagens na tela do computador do teleoperador avisando o transbordo do tempo médio de atendimento, podem contribuir para o adoecimento desses trabalhadores.

O item 5.15 ainda instituiu que os sistemas informatizados devem mitigar sobretarefas como a utilização constante de memória de curto prazo e duplicidade de registros de informações (anotação em papel e concomitantemente a alimentação do sistema com os 
mesmos dados), mais uma vez considerando a inter-relação pessoa-ambiente e os impactos dos aspectos organizacionais na saúde dos teleoperadores, tendentes a desencadear estresse e esgotamento psicofísico.

Os itens 5.11 e 5.12 foram instituídos para humanizar o atendimento de telemarketing, engessado pela obrigatoriedade de observância estrita do script ou roteiro de atendimento elaborado pelo empregador. O uso do script era obrigatório e sua inobservância, se constatada mediante procedimentos de monitoramento por escuta e gravação de ligações sem o conhecimento do teleoperador, era punida por sanção disciplinar (advertência verbal ou escrita, suspensão, anotação na avaliação para obstar a ascensão a cargos superiores, etc.), cuja informação era transmitido no treinamento de ingresso à função e prevista no regulamento interno das empresas do setor. Essa situação comprometia a subjetividade dos atendentes que sequer podiam elaborar (e pensar) a própria fala durante o diálogo travado com os clientes, cassando-lhe qualquer autonomia na função; se já não podiam dialogar livremente com os consumidores, quanto mais questionar ou discutir procedimentos com seus superiores hierárquicos.

Os itens 5.11 e 5.12 devem ser interpretados em conjunto com o item 8.2.1, alíneas "a" e "c", que relaciona o script ou o roteiro de atendimento à saúde vocal dos teleoperadores, ao impingir o dever dos empregadores implementarem modelos de diálogos que favoreçam micropausas e evitem carga vocal intensiva do operador, além de possibilitar a ingestão frequente de água potável, para hidratar as cordas vocais.

Outra regra importante instituída pelo Anexo II da NR 17 foi a vedação à utilização de métodos que causem assédio moral, medo ou constrangimento aos teleoperadores, prevista no item 5.13. As hipóteses apresentadas nesse item, de natureza exemplificativa e não taxativas, vedam o estímulo abusivo à competição entre trabalhadores ou equipes de trabalho (ilhas); a exigência do uso de adereços, fantasias e vestimentas como punição, promoção e propaganda; e a exposição pública das avaliações de desempenho dos teleoperadores, entre outras práticas.

O aludido item visa coibir práticas comuns ao setor, ilustradas nos arestos colacionados a seguir:

INDENIZAÇÃO POR DANOS MORAIS. IMPOSIÇÃO DO USO DE FANTASIA NO AMBIENTE DE TRABALHO. Hipótese em que a prova testemunhal é suficiente para autorizar a condenação ao pagamento de 
indenização por danos morais, restando evidente que a imposição de utilização de uma fralda geriátrica no ambiente de trabalho, como fantasia, extrapola os limites do poder diretivo do empregador, causando humilhação e constrangimento no empregado, violando, assim, sua imagem e sua honra (art. $5^{\circ}$, inc. X, da CF), além de afetar a dignidade do trabalhador (art. $\mathbf{1}^{\mathbf{0}}$, inc. III, da CF). Quanto ao valor arbitrado, entende-se razoável o montante de R\$ 3.000,00 (três mil reais), levando-se em conta a gravidade da ofensa e a respectiva sequela psíquica, bem como a capacidade econômica do ofensor e o fim punitivo-pedagógico da indenização, observando-se, ainda, os critérios de razoabilidade e proporcionalidade. Recursos da reclamada e do reclamante a que se negam provimento. (TRT 4 ${ }^{\mathrm{a}}$ Região. $7^{\mathrm{a}}$ Turma. 0001108-49.2010.5.04.0011 RO. Relator João Batista de Matos Danda. Julgamento: 12/07/2012) - grifo nosso.

INDENIZAÇÃO POR DANO MORAL. A intimidação por meio de gritos e conduta hostil do representante da empresa e a submissão do trabalhador a situações vexatórias, mediante o uso de fantasias e imitação de animais, configuram-se ofensivas a dignidade e fazem devida indenização por danos morais. (TRT $4^{\mathrm{a}}$ Região. RO 0000360-12.2010.5.04.0821. Relator: JOÃO GHISLENI FILHO. Julgamento: 09/11/2011) - grifo nosso.

AGRAVO DE INSTRUMENTO. DANO MORAL. SUBMISSÃO DE EMPREGADOS A EXPOSIÇÃO HUMILHANTE . NÃO-PROVIMENTO. A v. decisão recorrida entendeu pela existência de dano moral, com base na prova, ante a imposição pela empresa de humilhação aos empregados que não atingissem metas de vendas, fazendo-os portar fantasias e desfilar no ambiente da empresa, como castigo. Inviável a reforma do decisum sem o reexame do fato e da prova, o que encontra óbice na Súmula 126 do c. TST. (TST. 6 ${ }^{\text {a }}$ Turma. AIRR 126040-24.2005.5.03.0008. Relator: Aloysio Corrêa da Veiga. Julgamento: 08/11/2006. Publicação: DJ 01/12/2006) - grifo nosso.

\section{ASSÉDIO MORAL. COBRANÇA DE CUMPRIMENTO DE METAS COM XINGAMENTO E AMEAÇAS. DANO MORAL} CARACTERIZADO. A cobrança de metas faz parte do dia a dia de qualquer empresa como natural pressão decorrente do mercado de trabalho cada vez mais competitivo. Porém, quando feita pelo empregador, de forma abusiva, com intimidações e xingamento, em reuniões, na presença de outros empregados, configura-se a conduta abusiva atingindo a dignidade e a integridade psíquica do empregado. Reparação devida a título de dano moral. (TRT $1^{\mathrm{a}}$ Região. 10 $0^{\mathrm{a}}$ Turma. RO $\mathrm{n}^{\mathrm{o}}$ 013980096.2009.5.03.0138. Relatora Deoclécia Amorelli Dias. Publicação: 13/07/2010) - grifo nosso.

Não há barreiras para a inventividade das empresas do ramo. Em um inusitado caso julgado procedente em primeira instância e confirmado pelo Tribunal Regional da $15^{\mathrm{a}}$ Região, discutiu-se uma medida adotada por uma empresa de telemarketing, denominada "terça sem cadeira", que consistia em retirar todas as cadeiras dos supervisores nas terçasfeiras para que passassem toda a jornada executando suas atividades em pé. Defendeu-se a 
empregadora que a medida visava estimular os supervisores a se aproximarem de seus teleoperadores, intensificando a colaboração e a cobrança de resultados. Todavia, entendeu o Tribunal Regional da $15^{\text {a }}$ Região se tratar de assédio moral, condenando a empresa de telemarketing ao pagamento de indenização por danos morais ${ }^{353}$.

O item 5.10 chancela a sistematização dos fatores e aspectos constituintes do meio ambiente do trabalho proposta neste estudo, ao estabelecer o dever de considerar os seguintes elementos da organização do trabalho para fins de elaboração de programas preventivos: compatibilização de metas com as condições de trabalho e tempo oferecidas; monitoramento de desempenho; repercussões sobre a saúde dos trabalhadores decorrentes de todo e qualquer sistema de avaliação para efeito de remuneração e vantagens de qualquer espécie; pressões aumentadas de tempo em horários de maior demanda; e períodos para adaptação ao trabalho. Referenda, portanto, que os aspectos organizacionais compõem o meio ambiente do trabalho e repercutem na saúde dos trabalhadores.

Como a cobrança de metas e resultados é inerente à organização do trabalho em telemarketing, buscou esse item mitigar os impactos dessas medidas na saúde dos trabalhadores do setor, instituindo o dever de prevê-los em programas preventivos, como por exemplo, no Programa de Prevenção de Riscos Ambientais (PPRA) e no Programa de Controle Médico de Saúde Ocupacional (PCMSO), conforme salienta o item 8.5.

Os itens 8.1 e seguintes devem ser analisados em conjunto com o item 5.10. Prevê o item 8.1 o dever do Programa de Controle Médico de Saúde Ocupacional atender à Norma Regulamentadora 7, de modo a reconhecer e registrar os seguintes riscos identificados na análise ergonômica:

a) descrição das características dos postos de trabalho no que se refere ao mobiliário, utensílios, ferramentas, espaço físico para a execução do trabalho e condições de posicionamento e movimentação de segmentos corporais;

b) avaliação da organização do trabalho demonstrando:

1. trabalho real e trabalho prescrito;

2. descrição da produção em relação ao tempo alocado para as tarefas;

3. variações diárias, semanais e mensais da carga de atendimento, incluindo variações sazonais e intercorrências técnico-operacionais mais frequentes;

4. número de ciclos de trabalho e sua descrição, incluindo trabalho em turnos e trabalho noturno;

\footnotetext{
${ }^{353}$ Tribunal Regional do Trabalho da $15^{\text {a }}$ Região. $1^{\text {a }}$ Turma. RO 0153500-62.2008.5.15.006. Relatora: Tereza Aparecida Asta Gemignani. Publicação: 02/12/2011.
} 
5. ocorrência de pausas interciclos;

6. explicitação das normas de produção, das exigências de tempo, da determinação do conteúdo de tempo, do ritmo de trabalho e do conteúdo das tarefas executadas;

7. histórico mensal de horas extras realizadas em cada ano;

8. explicitação da existência de sobrecargas estáticas ou dinâmicas do sistema osteomuscular;

c) relatório estatístico da incidência de queixas de agravos à saúde colhidas pela Medicina do Trabalho nos prontuários médicos;

d) relatórios de avaliações de satisfação no trabalho e clima organizacional, se realizadas no âmbito da empresa;

e) registro e análise de impressões e sugestões dos trabalhadores com relação aos aspectos dos itens anteriores;

f) recomendações ergonômicas expressas em planos e propostas claros e objetivos, com definição de datas de implantação.

Vê-se, portanto, que a saúde do trabalhador na perspectiva do Anexo II da NR 17 não considera apenas os aspectos físicos e organizacionais do meio ambiente do trabalho, mas também aspectos psicológicos e comportamentais (fatores pessoais), haja vista que o item 8.4.1 estabelece o dever das análises ergonômicas contemplarem obrigatoriamente a discussão e restituição dos resultados aos trabalhadores envolvidos (alínea “c”) e a avaliação e revisão das intervenções efetuadas com a participação de teleoperadores, supervisores e gerentes (alínea “e”). Sacramenta a inter-relação pessoa-ambiente no processo de promoção de saúde, o Princípio da Participação - a participação democrática dos trabalhadores no processo de produção de medidas viabilizadoras do direito à saúde - e o Princípio da Informação - o dever de informar (dos empregadores) e o direito de ser informado (dos trabalhadores) sobre os riscos inerentes à atividade, por meio dos itens 8.1, alíneas "d" e "e" e 8.4.1, alíneas "c" e "e", a seguir transcritos:

8.4.1. As análises ergonômicas do trabalho deverão ser datadas, impressas, ter folhas numeradas e rubricadas e contemplar, obrigatoriamente, as seguintes etapas de execução:

a) explicitação da demanda do estudo;

b) análise das tarefas, atividades e situações de trabalho;

c) discussão e restituição dos resultados aos trabalhadores envolvidos;

d) recomendações ergonômicas específicas para os postos avaliados;

e) avaliação e revisão das intervenções efetuadas com a participação dos trabalhadores, supervisores e gerentes;

f) avaliação da eficiência das recomendações. - grifo nosso. 
Os itens 9.1 e 9.2 demonstram que os aspectos biogenéticos (fatores pessoais) integram o meio ambiente do trabalho e podem nele influir e repercutir na saúde dos trabalhadores. Preocupou-se o Anexo II da NR 17 com a mobilidade de pessoas com deficiência ao estabelecer em seu item 9.1 o dever de adaptação do mobiliário dos postos de atendimento às necessidades desses trabalhadores, como medida de saúde e segurança no trabalho. Não bastasse, previu no item 9.2 a adaptação das instalações, equipamentos, condições ambientais, capacitação, condições sanitárias, programas de prevenção, cuidados para segurança pessoal e até mesmo da organização do trabalho às necessidades dos trabalhadores com deficiência.

O item 5.7 talvez ainda seja o mais polêmico, cabendo sua recuperação para uma análise pormenorizada da casuística:

5.7. Com o fim de permitir a satisfação das necessidades fisiológicas, as empresas devem permitir que os operadores saiam de seus postos de trabalho a qualquer momento da jornada, sem repercussões sobre suas avaliações e remunerações.

Para os mais desavisados, esse dispositivo pode parecer um excesso de zelo do Ministério do Trabalho e Emprego, que resolvera instituir o óbvio: o direito dos teleoperadores satisfazerem suas necessidades fisiológicas, tal como deve ser e ocorre em diversas outras atividades. Porém, o uso do banheiro no contexto do trabalho em telemarketing é na atualidade um dos assunto mais controvertido nos tribunais trabalhistas e literatura jurídica e científica.

Para iniciar essa abordagem, que não por acaso deixou-se para o final desse subcapítulo, é preciso esclarecer que muitas demandas adentraram o judiciário trabalhista discutindo a caracterização de dano moral pelo impedimento do uso do banheiro pelos teleoperadores fora dos períodos de intervalo e pausas. Significa dizer que os aspectos organizacionais limitam a satisfação das necessidades fisiológicas, repercutindo na saúde psicofísica dos trabalhadores.

A justificativa das empresas é que os centros de atendimento comportam centenas de teleoperadores e o uso livre do banheiro poderia comprometer o atendimento das chamadas, caso o posto de atendimento fosse frequentemente abandonado ou se todos os 
teleoperadores, ou pelo menos uma considerável parcela, resolvessem se utilizar do banheiro ao mesmo tempo, sobretudo em horários de alta demanda de ligações.

Recentemente, em 06 de julho de 2012, o Colendo Tribunal Superior do Trabalho acolheu a pretensão indenizatória de uma teleoperadora que usufruía apenas cinco minutos para o uso do banheiro, sob pena de advertência caso esse limite fosse ultrapassado. Entendeu a $6^{\text {a }}$ Turma que a restrição do uso do banheiro pode configurar lesão à integridade do teleoperador, conforme se observa no aresto a seguir:

RECURSO DE REVISTA. CONCESSIONÁRIA DE SERVIÇOS DE TELECOMUNICAÇÕES. VENDA DE LINHAS DE TELEFONE POR MEIO DE ATENDIMENTO TELEFÔNICO. ATIVIDADE-FIM. TERCEIRIZAÇÃO ILÍCITA. 1. O Tribunal Regional entendeu que a atividade da reclamante, venda de linhas telefônicas, por meio de atendimento telefônico, na sede da Brasil Telecom S. A., não se identifica com a atividade-fim da reclamada. 2. O caput do art. 60 da Lei $n^{\circ}$ 9.472/97 dispõe que "Serviço de telecomunicações é o conjunto de atividades que possibilita a oferta de telecomunicação". Portanto, a atividade desenvolvida pela reclamante, venda de linhas de telefone, por meio de atendimento telefônico, ao teor do referido dispositivo de lei, identifica-se com a atividade-fim de uma empresa de telecomunicações. 3. O entendimento da Sexta Turma e o majoritário desta Corte é de que é ilícita a terceirização da atividade-fim. Recurso de revista a que se dá provimento. INDENIZAÇÃO POR DANO MORAL. RESTRIÇÃO DO USO DO BANHEIRO. TEMPO LIMITADO DE CINCO MINUTOS. 1. A jurisprudência desta Corte tem se firmado no sentido de que a restrição de uso de banheiros por parte do empregador, em detrimento da satisfação das necessidades fisiológicas do empregado pode configurar lesão à sua integridade. 2. No caso dos autos, consta que havia uma pausa de cinco minutos para ida ao banheiro, durante a jornada. Constata-se também que, se ultrapassado esse limite, o funcionário recebia advertência ou era interpelado pelo supervisor, o que configura lesão à integridade, que enseja indenização por dano moral. Precedentes. Recurso de revista a que se dá provimento. (TST. 6 ${ }^{\mathrm{a}}$ Turma. RR 154490039.2008.5.09.0001. Relatora: Kátia Magalhães Arruda. Publicação: 06/07/2012).

Tal entendimento não é isolado no Colendo Tribunal Superior do Trabalho. É compartilhado também por outras turmas e pela Subseção I Especializada em Dissídios Individuais, que ainda apontam violação ao princípio da dignidade da pessoa humana (artigo $1^{\circ}$, inciso III, da Constituição Federal) e abuso no exercício do poder diretivo da empresa (artigo $2^{\circ}$ da Consolidação das Leis do Trabalho) como fundamentos para a condenação de empresas de telemarketing ao pagamento de indenização por danos morais ao teleoperadores impedidos de usar o banheiro durante a jornada de trabalho, nos termos a seguir colacionados: 
RECURSO DE REVISTA. 1. DANO MORAL. RESTRIÇÃO AO USO DE BANHEIRO DURANTE A JORNADA DE TRABALHO. Nos termos da jurisprudência desta Corte Superior, a restrição ao uso de banheiros a apenas 1 intervalo de 5 minutos, por parte do empregador, inclusive com advertências, em detrimento da satisfação das necessidades fisiológicas do empregado, configura lesão à sua integridade a ensejar a indenização por dano moral. Recurso de revista não conhecido. (...). Recurso de revista não conhecido. (TST. $8^{\mathrm{a}}$ Turma. RR 2680100-74.2008.5.09.0009. Relatora: Dora Maria da Costa. Publicação: DEJT 27/06/2011).

RESTRIÇÃO AO USO DE BANHEIROS. ABUSO NO EXERCÍCIO DO PODER DIRETIVO. ATO ILÍCITO. DANO MORAL CONFIGURADO. Na hipótese dos autos, o Tribunal Regional, embora reconhecendo que se insere no poder diretivo do empregador a disciplina do uso do toalete pra trabalhadores que desenvolvem suas atividades em teleatendimento, afirmou, por outro lado, que essa limitação deve ser razoável, sob pena de afrontar direitos da personalidade, como entendeu ter ocorrido nos autos, em que reputou manifestamente ilícita a concessão de apenas cinco minutos diários, inclusive com a realização de advertências e interpelações, quando ultrapassa esse período. Este Tribunal Superior do Trabalho tem entendido que a submissão do uso de banheiros à autorização prévia fere o princípio da dignidade da pessoa humana (artigo $1^{\circ}$, inciso III, da Constituição Federal), traduzindo-se em verdadeiro abuso no exercício do poder diretivo da empresa (artigo $2^{\circ}$ da CLT), o que configura ato ilícito, sendo, assim, indenizável o dano moral sofrido pelos empregados. Precedentes desta Corte. Recurso de revista conhecido e provido. (TST. $2^{\text {a }}$ Turma. RR 22550056.2009.5.09.0014. Relator: José Roberto Freire Pimenta. Publicação: DEJT 27/04/2012).

DANO MORAL. RESTRIÇÃO AO USO DO TOALETE. DANO MORAL. TEMPO PARA O USO DO BANHEIRO. A dignidade é a pedra angular de todos os outros direitos e liberdades da pessoa humana: todas as pessoas são iguais, devem ser tratadas com respeito e integridade, e a violação deste princípio implica sanções pela lei. Pelo princípio da dignidade humana cada ser humano possui um direito intrínseco e inerente a ser respeitado, são seus próprios valores subjetivos - seu sistema de referências pessoais e morais que se revelam no universo coletivo. Todas as condutas abusivas, que se repetem ao longo do tempo e cujo objeto atenta contra o SER humano, a sua dignidade ou a sua integridade física ou psíquica, durante a execução do trabalho merecem ser sancionadas, por colocarem em risco o meio ambiente do trabalho e a saúde física e psicológica do empregado. Um meio ambiente intimidador, hostil, degradante, humilhante ou ofensivo que se manifesta em regra por palavras, intimidações, atos gestos ou escritos unilaterais que podem expor a sofrimento físico ou situações humilhantes os empregados deve ser objeto de proteção do legislador, do juiz e da sociedade. Nesse contexto, o empregador deve, pois, tomar todas as medidas necessárias para prevenir o dano psicossocial ocasionado pelo trabalho. Na particular hipótese dos autos, forçoso é convir que nem todos os empregados podem suportar, sem incômodo, o tempo de espera para uso dos banheiros, sem que tal represente uma agressão psicológica (e mesmo fisiológica) durante a execução do trabalho. A indenização em questão tem por objetivo suscitar a discussão sobre o papel do empregador na garantia dos direitos sociais fundamentais mínimos a que faz jus o trabalhador. Embargos conhecidos e desprovidos. (TST. E-ED-RR-159600-47.2007.5.03.0020. Subseção I 
Especializada em Dissídios Individuais. Relator: Aloysio Corrêa da Veiga. Publicação: DEJT 01/10/2010).

Contudo, o assunto ainda comporta controvérsias entre as turmas do Colendo Tribunal Superior do Trabalho, sobretudo quanto à exigência da comprovação do dano extrapatrimonial para a caracterização do dever de indenizar. Nos termos do aresto a seguir colacionado, embora entendesse a $1^{\text {a }}$ Turma que, ao firmar o contrato de trabalho, o empregado não se despoja dos direitos inerentes à sua condição de ser humano, que devem ser respeitados pelo tomador dos serviços, em face dos princípios da dignidade da pessoa humana e da boa-fé objetiva, negou-se a indenização pleiteada em razão da não comprovação do dano efetivo à honra, à imagem, à integridade psíquica e à liberdade pessoal do teleoperador:

RECURSO DE REVISTA - OPERADOR DE TELEMARKETING
LIMITAÇÃO DO TEMPO DE USO DE BANHEIRO DURANTE A
JORNADA DE TRABALHO - DANO MORAL - EXISTÊNCIA
POSSIBILIDADE - CONTROLE INDEVIDO SOBRE AS
NECESSIDADES FISIOLÓGICAS DO EMPREGADO - NÂO OCORRÊNCIA NA HIPÓTESE DOS AUTOS. A Constituição Federal de 1988 representa a decisão política fundamental do povo brasileiro acerca de quais valores devem nortear a condução dos negócios públicos e privados em nosso País. Nessa senda, a força normativa de seus preceitos impõe-se tanto às relações firmadas com as entidades da Administração Pública quanto àquelas estabelecidas entre particulares, pois, do contrário, estar-se-ia permitindo que a autonomia da vontade se sobrepusesse aos direitos e garantias fundamentais estabelecidos pelo poder constituinte originário, o que, desde que superado o formalismo positivista tão prestigiado no século XIX e na primeira metade do século XX, não mais se admite, tendo em vista o reconhecimento do conteúdo eminentemente valorativo dos princípios fundamentais positivados em nossa Carta Política. Em face disso, ao firmar o contrato de trabalho com o seu empregador, o empregado não se despoja dos direitos inerentes à sua condição de ser humano, que devem ser respeitados pelo tomador dos serviços, em face dos postulados da dignidade da pessoa humana e da boa-fé objetiva (arts. $1^{\circ}$, IV, da Carta Magna e 422 do Código Civil). Tendo essas premissas como norte interpretativo, o TST tem decidido reiteradamente que a restrição ao uso de toaletes por parte do empregador, em detrimento da satisfação das necessidades fisiológicas do empregado, pode configurar lesão à sua integridade física, mormente quando ela vem acompanhada de admoestações oriundas do tempo despendido pelo trabalhador com as referidas necessidades, ocasionando, assim, a condenação da empresa ao pagamento de danos morais. Na hipótese dos autos, foi registrado no acórdão regional que a reclamante não se desincumbiu de demonstrar satisfatoriamente o fato constitutivo de seu direito, qual seja, a ocorrência de constrangimento quanto à adoção da medida; não há comprovação de que medida adotada pela reclamada lesionava a integridade física da empregada; e não há, também, demonstração de que tenha sido atingida sua honra, imagem, integridade psíquica e liberdade pessoal, de modo a fazer jus à indenização por danos 
morais. Recurso de revista não conhecido. (TST. $1^{\text {a }}$ Turma. RR-10970035.2007.5.18.0002. Relator: Vieira de Mello Filho. Publicação: 19/12/2011).

Não há também consenso sobre a matéria nos Tribunais Regionais do Trabalho, conforme se pode observar nos entendimentos jurisprudenciais que seguem:

\section{Favoráveis}

DANO MORAL. DANO MORAL. LIMITAÇÃO DE USO DE BANHEIRO. CONFIGURAÇÃO. O dano moral representa uma violação à dignidade do indivíduo, a qual engloba os direitos à honra, ao nome, à intimidade, à privacidade e à liberdade. A fixação pelo empregador de qualquer parâmetro para a utilização de banheiro configura lesão extrapatrimonial, uma vez que ofende a honra e a dignidade do empregado. (TRT $1^{\text {a }}$ Região. $10^{\text {a }}$ Turma. RO 00561-2006-049-01-00-3. Relator: Marcos Cavalcante. Julgamento: 28/08/2007).

LIMITAÇÃO DO USO DE BANHEIRO. EXERCÍCIO ABUSIVO DO PODER DE DIREÇÃO PATRONAL. DANO MORAL CONFIGURADO. É inerente à natureza humana a satisfação das necessidades fisiológicas, não se podendo admitir que o empregador possa conceder tempo ínfimo para a utilização do banheiro, sujeitando a trabalhadora a explicações ao supervisor pelo excesso cometido. $\mathrm{O}$ poder de direção assim exercido viola gravemente a integridade psicológica da trabalhadora (art. 187,CC), sendo passível de indenização. Aplicação da jurisprudência atual do C. Tribunal Superior do Trabalho. (TRT 9a Região. $4^{a}$ Turma. RO 840-2011-892-9-0-8. Relator: Luiz Celso Napp. Publicação: 06/03/2012).

INDENIZAÇÃO POR DANOS MORAIS. LIMITAÇÃO DO USO DO BANHEIRO. A limitação do uso do banheiro durante a jornada de trabalho configura ofensa à dignidade da pessoa humana, garantida constitucionalmente, ensejando o dever de indenizar. Sentença mantida. (TRT 4 4 ${ }^{\mathrm{a}}$ Região. RO 0000684-64.2011.5.04.0013. Relator: Lucia Ehrenbrink. Publicação: 17/05/2012).

\section{Contrários}

RECURSO ORDINÁRIO - LIMITAÇÃO DO USO DO BANHEIRO INDENIZAÇÃO POR DANO MORAL - INDEFERIMENTO. Constatandose que a empresa apenas disciplinou a utilização do tempo despendido no sanitário, sem cercear ou inibir o direito de sua utilização, não há como deferir a indenização por danos morais, vez que inexistente $o$ constrangimento ou humilhação alegados. (TRT 6 ${ }^{\mathrm{a}}$ Região. RO 014800068.2009.5.06.0022. Relator: Nise Pedroso Lins de Sousa. Publicação: 20/01/2011).

DANO MORAL. LIMITAÇÃO DE USO DE BANHEIRO. O fato de a empresa controlar a ordem e os períodos de saída dos operadores do seu posto de trabalho, não importa em proibição de ir ao banheiro, mas sim, demonstra o rigor do empregador quanto ao controle das saídas dos 
empregados, diante da enorme quantidade de colaboradores que, por si só, não gera para o trabalhador o direito a reparação civil por danos morais. (TRT 18 ${ }^{a}$ Região. RO 02407-2009-002-18-00-2. Relator: Geraldo Rodrigues do Nascimento. Publicação: 26.10.2010).

RECURSO ORDINÁRIO. DANO MORAL. LIMITAÇÃO DO USO DO BANHEIRO. NÃO CONFIGURADO. Que a empresa apenas disciplinou a utilização do tempo despendido no sanitário, sem cercear ou inibir o direito de sua utilização, sendo certo que não parece razoável cogitar que todos os empregados pudessem utilizar de uma só vez aquelas dependências, mormente quando se tem um número elevadíssimo de trabalhadores laborando numa empresa. Recurso improvido no ponto. (TRT 6 ${ }^{a}$ Região. RO 0000683-71.2010.5.06.0009. Relator: Nise Pedroso Lins de Sousa. Publicação: 17/11/2011).

Credita-se a divergência sobre a matéria à tensão entre os interesses dos trabalhadores - fundados no princípio da dignidade da pessoa humana e nos direitos fundamentais à honra, à imagem, à saúde psicofísica e à liberdade pessoal - e os interesses patronais, sobretudo econômicos, a quem cabe o direito de organizar, dirigir e controlar a atividade laboral, nos termos do art. $2^{\circ}$ da Consolidação das Leis do Trabalho.

$\mathrm{O}$ aspecto organizacional dessa atividade é um outro fator que contribui para o tensionamento desses interesses. Sabe-se que a organização da atividade de telemarketing é pautada, essencialmente, no elemento "tempo". Controla-se o tempo de duração da chamada, de transferência de ligações e até mesmo de afastamento do teleoperador do posto de atendimento, para que não haja abandono de chamadas ou elevado tempo de espera dos clientes consumidores para serem atendidos. Esse elemento também é considerado para a contratação dos serviços das empresas de telemarketing, cujo contrato deve estipular o período e o número de posições dedicadas ao tomador. Portanto, se os teleoperadores são destinatários do direito ao trabalho digno e adequado, nele incluída a possibilidade de se ausentar do posto de atendimento para a satisfação de suas necessidades fisiológicas, por sua vez, os consumidores são destinatários do direito a um atendimento de qualidade, que compreende tanto a celeridade como a efetividade da prestação do serviço.

Contudo, a situação do uso do banheiro compreende abuso de ambos os lados, caracterizando um nefasto "cabo de guerra". Em uma das extremidades há empregadores que não dimensionam o contingente de teleoperadores às demandas da produção para evitar sobrecarga habitual, nos termos do item 5.2 no Anexo II da NR 17, e negligenciam as necessidades fisiológicas desses trabalhadores, que naturalmente ingerem muito líquido para 
lubrificar as cordas vocais durante a jornada; na outra extremidade, teleoperadores que reivindicam ampla liberdade de se ausentar do posto de atendimento, além do intervalo e das pausas permitidas. Nem se cogita situações específicas, como o caso de gestantes, lactantes e teleoperadores com problemas no sistema urinário, porque naturalmente precisam se utilizar do banheiro com mais frequência do que os outros teleoperadores e eventual negativa por parte do empregador caracterizaria abuso no exercício do poder diretivo da empresa em detrimento das normas de proteção à mulher e do direito fundamental da saúde do trabalhador.

Nesse compasso, merece relevo a opinião de uma dos participantes deste estudo sobre o assunto em exame:

Sobre o banheiro eu gostaria de fazer alguns comentários, porque eu tenho posições dos dois lados. O uso do banheiro não foi resolvido ainda. Sempre houve abuso dos dois lados. Eu tenho essa percepção antiga, mas não acusa um movimento de ensejar dano moral. Isso é notório em todos os lados. As situações de danos morais estavam associadas a extrema gravidade, que podia chegar até o óbito do trabalhador. Não se reivindicava a título de dano moral uma mora salarial, um atraso nas verbas rescisórias e hoje, como todo mundo sabe, isso se tornou mais comum. Os abusos acontecem de parte a parte, por quem? Do empregador, todos os afastamentos do posto de atendimento são onerosos; as famosas filas de espera do atendimento, aquela equação que se faz super enxuta de quem tem 30 pessoas atendendo... se tiver 29 já dá uma conta diferente. Do outro lado, os empregados, especialmente antes da NR, não tem outra forma de descomprimir, de descongestionar a não ser ir ao banheiro. Não estou nem falando da má-fé no sentido de ir ao banheiro no sentido de blefar, de lesar o empregador, estou falando simplesmente do ato de se levantar, caminhar 20 passos e voltar como uma forma de descomprimir um pouco as têmporas, de fazer com que a circulação sanguínea seja reativada, dependendo da jornada estafante. Isso porque nossa conversa gira em torno de um profissão com um desgaste. Isso valeria também pra outras situações, de pessoas que tem necessidade de se levantar. No trabalho intelectual não é muito diferente disso. A partir de um certo momento de leitura ou de redação de uma peça processual, você precisa pelo menos se espreguiçar. É comum que a ida ao banheiro seja uma válvula de escape. Pouca gente comenta que essas pessoas precisam de lubrificação da garganta, porque falam o dia inteiro. Esquecem que essas pessoas bebem mais líquidos do que a média dos trabalhadores. A medicina recomenda um litro e meio, um litro de água por dia. Essas pessoas talvez ingiram isso durante o expediente de 6 horas. Eles normalmente trabalham com garrafas plásticas. Isso é uma realidade daqueles pontos de atendimentos. Somando tudo isso, nós temos uma inovação no uso do toalete e hoje no fumódromo também que, no Estado de São Paulo, por sua vez, foi proibido. A NR 17 provavelmente quis disciplinar a situação e inseriu uma frase: "o uso do toalete não pode ser restritivo, contanto que a pessoa peça licença, observando-se uma ordem". Os dois pontos enxergaram essa frase de sua maneira: os trabalhadores enxergaram como uma liberdade total e irrestrita e as empresas enxergaram como uma liberdade pra proibir, pra fazer a fila do banheiro e pra pedir a licença. Eu acompanho com muito 
atenção isso e acho que, na minha sensibilidade, o vento sopra contra os trabalhadores nesse assunto, porque os acórdãos da SDI - só pra ficar na seção especializada de dissídios individuais - começaram a sair. Eles todos começaram a sair com fundamento de que as três pausas seriam suficientes para uma empresa, salvo a gestante, pessoas sob o tratamento de diuréticos e outras situações que não vêm ao caso. Porque uma jornada de 6 horas, excepcionalmente com 3 pausas, com uma ida ao banheiro a cada uma hora... E ainda tem aquele lance de que a pausa não pode ser nem na primeira nem na última... Então estamos falando de 3 pausas em 4 horas. Seria muito uma pessoas dizer que em 4 horas precisou ir 5 vezes ao banheiro. A gestante tudo bem, pois precisa ser tratada de uma forma diferente, como está acontecendo. Então acredito que os trabalhadores perderão essa batalha, mas por outros motivos, pensando nas necessidades fisiológicas. (Participante: MT1).

Concordamos com a posição desse participante, que reflete bem o tratamento da matéria pela jurisprudência. O Anexo II da NR 17 foi um divisor de águas quanto ao uso do banheiro no contexto do telemarketing. Antes do advento desse anexo, os teleoperadores contavam apenas com um intervalo de quinze minutos, quando submetidos à jornada de seis horas; àqueles que cumpriam jornada de quatro horas, nenhum intervalo lhes era garantido. Em razão disso, surgiu o embate quanto ao uso do banheiro, pois a permissão para se ausentar do posto de atendimento para a satisfação das necessidades fisiológicas dependia da benevolência dos supervisores, tanto nos casos em que o trabalhador já havia usufruído do intervalo que lhe era permitido como naqueles em que não se previa nenhum intervalo em virtude da jornada de trabalho inferior a seis horas. Essa inflexibilidade podia sim caracterizar dano moral, o que evidentemente não se discute.

Todavia, o Anexo II da NR 17 ampliou o intervalo para repouso e alimentação de 15 para 20 minutos, prevendo ainda a concessão de mais duas pausas de 10 minutos cada, após os primeiros e antes dos últimos sessenta minutos de trabalho. E para os trabalhadores submetidos à jornada de quatro horas instituiu o dever de concessão de uma pausa contínua de 10 minutos. Com isso, resolveu-se o problema do uso do banheiro, não por meio da permissão ampla e irrestrita para o teleoperador se ausentar do posto de atendimento, o que poderia a comprometer a qualidade da prestação do serviço e sobrecarregar o atendimento, mas através da ampliação do tempo do intervalo e do dever de concessão de pausas especiais, retiradas pelo referido anexo do campo da autonomia dos supervisores.

Não se quer dizer que a Justiça do Trabalho se libertou dessa celeuma. A frustração do direito ao intervalo para repouso e alimentação e às pausas especiais pelo 
empregador, sobretudo quando restar comprovada a restrição ao uso do banheiro justificadamente requerido pelo teleoperador, configura lesão à sua integridade a ensejar a indenização por dano moral, cujo constrangimento e humilhação são presumíveis. E, nesse caso, dispensável a comprovação do dano efetivo, pelo mero descumprimento do Anexo II da NR 17 e pelo raciocínio lógico de que a proibição injustificada e perversa da satisfação de uma real necessidade fisiológica atinge tanto a esfera da dignidade da pessoa humana como a saúde do trabalhador. Parece-nos que a jurisprudência tem adotado esse entendimento, chancelado pelo bom senso e pela harmonização dos interesses econômicos e sociais.

Desta feita, ao se afirmar que o Anexo II da NR 17 levou a sério a inter-relação pessoa-ambiente, não se ousa aventar que todas as demais normas regulamentadoras se esqueceram do organismo vivo do meio ambiente do trabalho, que é o trabalhador, haja vista que todas elas existem pelos e para os trabalhadores. $\mathrm{O}$ que se quer concluir é que pontuou bem o Ministério do Trabalho e Emprego ao lançar luzes à atividade contemplando toda a complexidade do meio ambiente do trabalho, abrangendo tanto os fatores físicos ambientais como os fatores pessoais, nele inclusos os aspectos psicológicos e comportamentais.

Este é o primeiro passo para se pensar em medidas preventivas para afastar doenças psicológicas comuns à atividade (depressão, estresse, síndrome do pânico, síndrome do esgotamento nervoso, etc.). É também um importante passo para que peritos judiciais e previdenciários passem a considerar em suas investigações que os fatores pessoais também integram o meio ambiente do trabalho e são influenciados pelos aspectos organizacionais da atividade, podendo comprometer a saúde psicofísica daqueles que se ativam naquele contexto laboral.

\subsubsection{O trabalho em telemarketing após a vigência do Anexo II da Norma Regulamentadora $\mathbf{n}^{\circ} 17$}

Desde a aprovação do Decreto $n^{\circ} 6.523 / 08$, somente em jornais foram publicadas diversas matérias sobre a fiscalização e a satisfação dos consumidores com as novas regras para o telemarketing. Todavia, pouco se falou as condições de trabalho dos teleoperadores após o Anexo II da NR 17 do mundo do trabalho; pouco se sabe se as empresas do setor se adaptaram ao conteúdo dessa norma regulamentadora e quais foram as dificuldades encontradas. 
Como proposta para futuros estudos, o levantamento desses dados por meio de uma metodologia empírica seria uma importante contribuição para o campo da saúde do trabalhador, sobretudo se analisados estatisticamente.

Questionado sobre os impactos do Decreto nº 6.523/08 e do Anexo II da NR 17, o Sindicato entrevistado, que representa a categoria profissional no Estado de São Paulo, apontou o aumento da quantidade de atendimento, salientando alguns impactos na saúde dos teleoperadores:

Eu acredito que aconteceu muita coisa. Primeiro, porque as empresas se viram com uma obrigação para a qual elas não estavam preparadas. E o impacto maior aconteceu exatamente em relação ao trabalhador, porque se ele fazia 10 atendimentos por hora, passou a fazer 12, 15 atendimentos. Então isso gera um problema muito grave para o trabalhador, primeiro porque prejudica a voz... você falando muito tempo seguido, seguindo um script, porque você não pode sair fora daquele script, então o que acontece... você acaba tendo uma sobrecarga em suas cordas vocais. E aí, normalmente, tem acontecido muitos problemas em relação a saúde nessa parte. Por um outro lado, depois de algum tempo, como eu disse antes, as empresas começaram a entender que precisavam abrir mais postos de trabalho e houve uma certa acomodação. Mas ainda hoje existe uma sobrecarga muito grande de trabalho.

Apontou, ainda, a dificuldade enfrentada pelas empresas para equacionar o atendimento com o intervalo para repouso e alimentação e as pausas especiais instituídas pelo Anexo II da NR 17:

O tempo para as pessoas realmente descansarem é um tempo mínimo, pela quantidade de ligações e de também funcionários, o que ocorre é que não existe uma forma adequada de dar esse descanso de 10 minutos nas primeiras 3 horas de trabalho e mais os 10 minutos na segunda fase, e tendo nesse meio aí ainda um descanso de 20 minutos. Para as empresas equacionarem esses detalhes fica muito complicado. Muitas vezes tem várias pessoas paradas ao mesmo tempo e em outros casos as pessoas não podem parar o atendimento, porque é necessário completar as ligações, o atendimento ao cliente, o que gera o acúmulo do descanso em cima do outro e de repente você tem lá uma quantidade de pessoas fazendo o descanso muito grande e começam acumular as ligações, começa novamente extrapolar o tempo de atendimento.

Outro ponto investigado diz respeito ao conhecimento pelos teleoperadores do teor do Anexo II da NR 17, essencial para a efetivação das garantias previstas naquela regulamentação. 
Dentre todos os participantes ouvidos neste estudo, apenas um apontou que os teleoperadores não tem conhecimento sobre o Anexo II da NR 17, de acordo com sua experiência profissional. Os demais, independentemente do grau de informação, apontaram que esses trabalhadores dominam o assunto. Um dos participantes justificou que os teleoperadores, quando ouvidos em juízo, além de mencionarem o termo "NR" e a Portaria n 9 do Ministério do Trabalho e Emprego, mencionam os termos "pausas" e ainda fazem comparação entre o período anterior e posterior ao Anexo II da NR 17, de acordo com o recorte a seguir transcrito:

Já faz muito tempo que eu dialogo com da seguinte maneira: as pausas da NR 17 eram observadas. A primeira vez que eu vi isso eu achei que a pessoa estava tirando uma da minha cara ou haviam sido instruídos pelo advogado. E não era. Ela estava falando com sinceridade. Está acabando o período anterior a NR, ainda assim eu me deparo com pessoas que vivenciaram os dois períodos. Quando eu pergunto como eram os intervalos, elas falam: “antes da NR, 15 minutos, depois da NR, 10+20+10". Então eles usam a palavra NR. A primeira forma de responder a sua pergunta é dizer que eles até sabem falar Norma Regulamentadora ou falam Portaria $\mathrm{n}^{\circ} 9$ do Ministério do Trabalho. Já está bom demais! Não dá pra exigir mais do que isso. Segundo, eles conhecem bem as necessidades após xingamento, após hostilidades... a sala de descompressão - eu não sabia desse nome - e eles me falam abertamente: "Eu dei pausa... eu pausei pra ir pra sala de descompressão". Eles sabem falar abertamente isso e não tem havido questionamento por parte dos empregadores, de acusar de desídia. (Participante: MT1).

Para justificar o conhecimento pelos teleoperadores do conteúdo do Anexo II da NR 17, um outro participante esclareceu que a internet tem colaborado para a difusão dos direitos dessa classe, predominantemente jovem, interessada e beneficiada por diversos meios de comunicação:

Hoje já há uma certa pacificação quanto a isso. Eu tenho percebido a maioria das empresas já tem observado a NR, então já diminuiu bastante, face a comparação com o período de transição da edição da NR. Hoje em dia eu vejo com mais frequência o cumprimento da redução da jornada, dos intervalos. (...) Olha, estão informados! Eu acho que é um público conectado. Eu acho que sim, Doutor. Eu acho que não há desconhecimento quanto ao teor do Anexo não. (Participante: MT3).

Todavia, o descumprimento e a desinformação sobre o teor do Anexo II da NR 17 ocorre, evidentemente, em empresas menores, com poucos teleoperadores, que fogem à fiscalização do Ministério do Trabalho e Emprego e dos sindicatos profissionais. Prova disso 
é que o sindicato participante deste estudo relatou que somente as empresas com mais de cinquenta empregados são fiscalizadas de forma mais incisiva.

Assim sendo, pouco se sabe sobre o efetivo impacto do Anexo II da NR 17 no contexto de telemarketing e se as empresas do setor se adequaram aos seus dispositivos, reestruturando a atividade e adequando a organização do trabalho às condições previstas na referida normatização.

\subsection{Telemarketing e outra(s) atividade(s): semelhanças}

Questionados se haveria outra atividade profissional assemelhada ao telemarketing, considerando a organização do trabalho (rígido controle, pressão por produtividade, etc.) a tensão entre interesses trabalhistas e consumeristas e a precarização das condições laborais, todos os participantes deste estudo apontaram semelhanças entre os setores bancário e de telemarketing, guardadas as devidas especificidades.

Outras atividades profissionais também tem recebido especial atenção do legislador, buscando instituir melhores condições de trabalho e reguardar a saúde dos trabalhadores.

É o caso dos motoristas profissionais que se ativam no transporte rodoviário de passageiros e de cargas, recentemente beneficiados pela Lei $\mathrm{n}^{\circ} 12.619$, de 30 de abril de 2012, que cuidou de instituir diversas medidas de preservação da saúde dessa categoria, entre elas: um intervalo mínimo de 30 (trinta) minutos para descanso a cada 4 (quatro) horas de tempo ininterrupto de direção e um intervalo mínimo de 1 (uma) hora para refeição (art. 235-D, incisos I e II, da Consolidação das Leis do Trabalho, incluído pela Lei $n^{\circ}$ 12.619/2012); benefício de seguro obrigatório, custeado pelo empregador e destinado à cobertura dos riscos pessoais inerentes às suas atividades, no valor mínimo correspondente a 10 (dez) vezes o piso salarial de sua categoria ou em valor superior fixado em convenção ou acordo coletivo de trabalho (art. $2^{\circ}$, parágrafo único, da Lei ${ }^{\circ} 12.619 / 2012$ ); e condições sanitárias e de conforto adequadas nos locais de espera (art. $9^{\circ}$ da Lei $\left.n^{\circ} 12.619 / 2012\right)$. Observa-se, neste caso, que o legislador, tal como fez em relação aos trabalhadores em telemarketing, fixou um tempo mínimo de intervalo para repouso e alimentação e instituiu um intervalo de 30 (trinta) minutos 
para descanso a cada 4 (quatro) horas de tempo ininterrupto de direção, buscando reduzir a exposição dos motoristas profissionais aos riscos e à penosidade da atividade.

Um outro exemplo é a Lei Municipal $n^{\circ} 4.890 / 2011$, aprovada pela Câmara Municipal de Alegrete, interior do Estado do Rio Grande do Sul, que dispôs sobre a obrigatoriedade dos supermercados, com três ou mais caixas de atendimento, disponibilizarem empacotadores de modo a equacionar o atendimento à demanda, evidenciando o fenômeno abordado neste estudo acerca da interdependência entre os contextos consumerista e trabalhista.

Embora buscasse a referida lei proporcionar dignidade e qualidade de vida aos clientes dos supermercados da cidade e melhores condições de trabalho aos empregados que se ativam no registro dos preços e acumulam a função de empacotadores, o Sindicato Intermunicipal do Comércio Varejista de Gêneros Alimentícios do Rio Grande do Sul ajuizou a Ação Direta de Inconstitucionalidade $n^{\circ} 70047284617$, alegando violação do art. 22, inciso I, da Constituição Federal, que prevê a competência exclusiva da União para legislar sobre matéria atinente ao Direito do Trabalho, e ao artigo 170, parágrafo único, também da Constituição Cidadã, que assegura a todos o livre exercício de qualquer atividade econômica, independentemente de autorização dos órgãos públicos. Acompanhando o parecer da Procuradoria Geral do Estado do Rio Grande de Sul, em 6 de agosto de 2012 o Tribunal Pleno do Estado, por maioria de votos, declarou a inconstitucionalidade da Lei Municipal $\mathrm{n}^{\circ}$ 4.890/2011, sob o fundamento de que não pode o município interferir nas relações de trabalho, cuja competência é privativa da União.

Contudo, suspeita-se que caso a discussão se concentrasse na qualidade da prestação do serviço aos consumidores, ao tempo de espera na fila dos caixas, ao horário e dias de funcionamento do comércio local, haveria grandes chances de se confirmar a constitucionalidade da lei em comento, o que seria uma importante conquista desses trabalhadores. Isso porque a Constituição do Estado do Rio Grande do Sul, em seu art. 13, incisos I e II, chancela a competência do município para as tratativas dessas matérias, nos termos a seguir evidenciados:

Art. 13 - É competência do Município, além da prevista na Constituição Federal e ressalvada a do Estado:

I - exercer o poder de polícia administrativa nas matérias de interesse local, tais como proteção à saúde, aí incluídas a vigilância e a fiscalização sanitárias, e proteção ao meio-ambiente, ao sossego, à higiene e à 
funcionalidade, bem como dispor sobre as penalidades por infração às leis e regulamentos locais;

II - dispor sobre o horário e dias de funcionamento do comércio local e de eventos comerciais temporários de natureza econômica; (...).

Com a devida licença, convém ainda lançar luzes a fragmentos do extenso voto divergente do Desembargador Jorge Luiz Lopes do Campo, acompanhado por mais três desembargadores:

A inconstitucionalidade incidental da Lei $\mathrm{n}^{\circ} 4.890$, de 12 de dezembro de 2011, do Município de Alegrete, não constitui ofensa ao princípio da livre iniciativa, nem a Constituição Federal ou a Estadual, pois a norma em questão visa melhorar o atendimento dos consumidores nos caixas de pagamento dos mercados e hipermercados naquela cidade, o que pressupõe a existência do número mínimo de funcionários para tanto naqueles estabelecimentos empresarias.

Note-se que este colegiado tem decidido, reiteradamente, que não há qualquer inconstitucionalidade na fixação de horário máximo de atendimento nos caixas de supermercados por parte dos municípios deste Estado, o que importa na necessária contratação de funcionários suficientes, dentre os quais empacotadores, para atender este tipo de regulação. Logo, a normatização reversa deste tipo de situação jurídica, ou seja, a contratação de empregados para diminuir o tempo de demora do consumidor no atendimento para pagar a sua conta e sair daquele estabelecimento, também não pode gerar a alegada inconstitucionalidade.

Destarte, a mera previsão de pessoal suficiente para o atendimento dos consumidores, constitui obrigação das empresas em disponibilizar este número mínimo de funcionários para tanto, de sorte que a referida regra municipal visa dar cumprimento a função social no desempenho da atividade privada em questão, valor preponderante sobre a livre iniciativa, interpretação conforme a ser dada no caso dos autos, cuja constitucionalidade vem sendo reiteradamente reconhecida pelo Supremo Tribunal Federal em casos análogos (...).

Além disso, conforme define Amauri Mascaro Nascimento, o direito do trabalho é o ramo da ciência do direito que tem por objeto as normas jurídicas que disciplinam as relações de trabalho subordinado, determinam os seus sujeitos e as organizações destinadas à proteção desse trabalho, em sua estrutura e atividade.

Desse modo, de acordo com a definição precitada, a norma que determina a disponibilização de pessoal suficiente ao cumprimento de prazos de atendimento não se refere a regulação do direito do trabalho, inexistindo violação, portanto, ao artigo 22, I, da Constituição Federal e, consequentemente, ao artigo $8^{\circ}$ da Constituição Estadual.

Do mesmo modo, não há falar em violação ao princípio da livre iniciativa, porquanto esse, no contexto de uma Constituição preocupada com a realização da justiça social (o fim condiciona os meios), não pode significar mais do que "liberdade de desenvolvimento de empresa no quadro 
estabelecido pelo Poder Público e, portanto, possibilidade de gozar das facilidades, e necessidade de submeter-se às limitações postas pelo mesmo"354.

Portanto, a liberdade de iniciativa deve ser exercida respeitando as normas impostas pelo Poder Público para o desempenho daquela atividade econômica, em especial aquelas de ordem pública e de interesse local que objetivam aprimorar o atendimento e prestação de serviços adequados aos consumidores. (...).

Então, sob este argumento de que, em um momento decidimos que sim, o Município pode regular o tempo de atendimento nos caixas de supermercado, hipermercado e por aí vai, e que para tanto é necessária, por razões óbvias, a contratação de funcionários, parece-me um excesso, no raciocínio reverso, se o ente público municipal estabelecesse regra dizendo que: ora, as empresas têm que contratar funcionários para que seja atendido rápida e eficazmente o consumidor. (...) (TJRS. Proc. $\mathrm{n}^{\mathrm{o}} 70047284617$. Relator Francisco José Moesch. Publicação: 08/10/2012).

Observa-se, portanto, que o insucesso da Lei $n^{\circ} 4.890 / 2011$ deu-se pela forma como o assunto foi enfrentado no texto legal. Para que fosse reconhecida sua constitucionalidade, bastaria que o legislador instituísse o dever dos supermercados equacionarem o atendimento à demanda, conforme fez o Anexo II da NR 17, em seus itens 5.2 e .5.2.1. Indiretamente, os trabalhadores do setor também seriam beneficiados, em virtude da interdependência entre os contextos consumerista e trabalhista.

Não se previu no objetivo deste estudo abordar as particularidades de outra atividade senão as de telemarketing, em razão da expressividade desse contexto nos últimos anos, das discussões em matéria de saúde do trabalhador e de seu importante papel como mecanismo de harmonização da relação de consumo. Contudo, convém destacar algumas semelhanças entre a atividade laboral no setor de telemarketing e no setor bancário, apontado unanimemente pelos participantes deste estudo, que podem ser úteis para fomentar futuros estudos e intervenções sobre a relação entre meio ambiente do trabalho e saúde do trabalhador.

Cynthia Suennia Damasceno Lucena de Paiva e Lívia de Oliveira Borges explicam que a reestruturação produtiva do setor bancário brasileiro tornou-se mais evidente a partir de 1960, com a criação dos centros de processamento de dados, instituindo um processo de mudanças tecnológicas e de gestão que repercutiram no conteúdo organizacional da

\footnotetext{
${ }^{354}$ SILVA, José Afonso da. Comentário contextual à constituição. 4. ed. São Paulo: Malheiros Editores, 2007. p.
} 711. 
atividade, visando à automação dos serviços (caixas automáticos, bancos 24 horas, serviços online, etc.), a redução de custos, a terceirização de atividades, a migração de parte do atendimento para o telemarketing e a desverticalização da estrutura organizacional através da limitação nas agências de apenas dois níveis hierárquicos (gerentes e atendentes) ${ }^{355}$.

Antes disso, já se conferia no final da década de 80 um movimento de expropriação do saber bancário através da substituição do conhecimento em contabilidade pela habilidade no manejo das máquinas, rapidez nos gestos corporais e destreza manual na execução de tarefas habituais ${ }^{356}$, tendentes ao desencadeamento de sintomas de estresse, nervosismo, ansiedade, gastrite, tensão e dor de cabeça crônica.

Os trabalhadores do setor bancário integram o grupo que mais sofre acidentes do trabalho por LER/DORT, em razão da imprevisão de pausas regulares, equipamento ergonômicos, ritmo de trabalho extenuante e intensa pressão para o cumprimento de metas e retorno ao trabalho nos casos de afastamentos, temor do desemprego e alta competitividade intralaboral.

Com o objetivo de compreender a saúde mental do bancário a partir das condições do meio ambiente de trabalho, o estudo realizado por Cynthia Suennia Damasceno Lucena de Paiva e Lívia de Oliveira Borges constatou que parte da amostra (44\%) constituída por 200 bancários, predominantemente do sexo masculino e casados, apresentou indicativos de insatisfação, depressão e tensão emocional relacionados com a organização e as relações de trabalho. Justificam que a privatização, a concorrência entre as instituições bancárias, a desregulamentação do mercado financeiro e a descaracterização da segurança do emprego bancário são elementos que influenciaram na saúde dos trabalhadores do setor ${ }^{357}$. Concluíram que os aspectos ambientais repercutiram positivamente na saúde mental dos bancários, com exceção das relações interpessoais comprometidas pelo aumento da competitividade intralaboral ${ }^{358}$.

Contudo, sob a perspectiva sistêmica corroborada pelo Princípio da Interdependência proposto neste estudo, os aspectos organizacionais - que integram os fatores

\footnotetext{
${ }^{355}$ PAIVA, Cynthia Suennia Damasceno Lucena de; BORGES, Lívia de Oliveira. O ambiente de trabalho no setor bancário e o bem-estar. Psicologia em Estudo, Maringá, v. 14, n. 1, p. 57-66, jan./mar. 2009.

356 BLASS, Leila Maria da Silva. Trabalho bancário: O (re)fazer de todo instante. Cadernos de Formação Sindical, São Paulo, n. 2, p. 20, 1989.

${ }^{357}$ PAIVA, Cynthia Suennia Damasceno Lucena de; BORGES, Lívia de Oliveira. Op. cit.

${ }^{358}$ Ibidem.
} 
ambientais constitutivos do meio ambiente do trabalho - e os aspectos psicológicos dos trabalhadores - que integram os fatores pessoais constitutivos do meio ambiente do trabalho são interdependentes, não havendo que considerá-los apartadamente. Assim, a organização da atividade bancária repercute tanto na forma como os trabalhadores vivenciam e se determinam diante do contexto laboral como nas relações com seus pares e consumidores. Por assim ser, se a própria organização do trabalho é afinada para acirrar a competitividade entre os trabalhadores que integram aquele contexto, ao ponto de precarizar as relações interpessoais e influir negativamente na saúde dos bancários, supõe-se o desequilíbrio do meio ambiente do trabalho. Daí não há que se falar em repercussão positiva dos aspectos ambientais na saúde mental dos trabalhadores, haja vista que, na perspectiva deste estudo, os aspectos organizacionais integram os fatores ambientais constituintes do meio ambiente do trabalho.

Assim como ocorre com os teleoperadores, os bancários também são cobrados pela produtividade, da qual depende a ascensão na estrutura funcional hierárquica, o incremento salarial, os benefícios associados às metas de produção (por exemplo, a Participação nos Lucros e Resultados - PLR) e até mesmo a manutenção no emprego. São compelidos a atingir metas pré-estabelecidas referentes a abertura de contas correntes e poupanças, adesão a seguros de vida, de automóvel ou residencial, planos de previdência privada, cartões de crédito e contratação de investimentos, empréstimos, financiamentos, entre outros produtos e serviços. Não se duvida que esses aspectos influenciam na competitividade entre os bancários e no temor de demissão, confirmando a interdependência dos indicativos de insatisfação, depressão e tensão emocional com a organização do trabalho e as relações interpessoais, ambas constitutivas do meio ambiente do trabalho.

Marcia Elena Rodrigues Gravina e Lys Esther Rocha apontam que a maioria os casos de adoecimento no setor bancário diz respeito a distúrbios osteomusculares relacionados ao trabalho e lesões por esforços repetitivos (DORT/LER). Mencionam diversos estudos epidemiológicos que registram alguns aspectos do meio ambiente do trabalho, ambientais e pessoais, como principais fatores para a gênese da LER/DOR, como por exemplo: a automação, a sobrecarga no trabalho, os critérios de avaliação, a responsabilidade excessiva, as características pessoais, a pressão do tempo e a influência negativa das normas internas de 
trabalho ${ }^{359}$. Nota-se, portanto, uma similaridade entre o contexto bancário e de telemarketing, sobretudo em relação aos impactos do aspecto organizacional na saúde psicofísica dos trabalhadores, reforçando a inter-relação trabalhador-ambiente e a interdependência de variáveis para a explicação causal do adoecimento nesses contextos.

Outro ponto em comum é a alta rotatividade ocupacional. Segundo o Departamento Intersindical de Estatística e Estudos Socioeconômicos (DIEESE), os banco substituem profissionais com salários mais altos por novos empregados com menor remuneração, buscando elevar os lucros que, entre 2004 e 2011, passou de R \$ 23,3 bilhões para R\$53,4 bilhões ${ }^{360}$.

Com base nos registros do Cadastro Geral dos Empregados e Desempregados (CAGED), segundo o DIEESE, entre 1989 e 1996 o número de empregados no setor passou de 824.316 para 497.108 e, em 2001, decaiu para 393 mil empregados. Apenas entre 2002 a 2011 o total de empregados no setor bancário alcançou um crescimento contínuo, atingindo a marca de 508 mil bancários.

De acordo com a Confederação Nacional dos Trabalhadores do Ramo Financeiro, a queda do número de empregos bancários na década de 90 deu-se, sobretudo, em razão do processo de terceirização dos serviços com o intuito de reduzir custos ${ }^{361}$. Todavia, deve-se também considerar que a automação dos serviços e o enxugamento das funções nas agências bancárias contribuíram substancialmente para tal decréscimo. Esse fenômeno ilustra a influência do sistema econômico - como elemento constituinte do macrossistema - no meio ambiente do trabalho, impactando, inclusive, nas condições laborais e no sistema social, evidenciando uma interdependência sistêmica consubstanciada no Princípio da Interdependência construído neste estudo.

Já o crescimento da quantidade de bancários empregados no país nos últimos anos deve-se à pressão da sociedade insatisfeita com o reduzido número de trabalhadores nas

\footnotetext{
359 GRAVINA, Marcia Elena Rodrigues; ROCHA, Lys Esther Rocha. Lesões por Esforços Repetitivos em bancários: reflexões sobre o retorno ao trabalho. Cadernos de Psicologia Social do Trabalho, São Paulo, v. 9, n. 2, p. 41-55, 2006.

${ }^{360}$ OLIVEIRA, Fernando César. Dieese: mesmo crescendo nos últimos dez anos, emprego no setor bancário é $70 \%$ do total há duas décadas. Agência Brasil - Empresa Brasil de Comunicação, 22 jul. 2012. Disponível em: $<$ http://agenciabrasil.ebc.com.br/noticia/2012-07-22/dieese-mesmo-crescendo-nos-ultimos-dez-anos-empregono-setor-bancario-e-70-do-total-ha-duas-decadas>. Acesso em: 30 set. 2012.

${ }^{361}$ PAIVA, Cynthia Suennia Damasceno Lucena de; BORGES, Lívia de Oliveira. O ambiente de trabalho no setor bancário e o bem-estar. Psicologia em Estudo, Maringá, v. 14, n. 1, p. 57-66, jan./mar. 2009.
} 
agências, segundo a Confederação Nacional dos Trabalhadores do Ramo Financeiro ${ }^{362}$, destacando a influência das políticas consumeristas no universo do trabalho, sobretudo na organização laboral. Essa insatisfação impulsionou a regulamentação por alguns estados (por exemplo, São Paulo, Rio de Janeiro, Rio Grande do Sul, Minas Gerais, Paraná, etc.) e municípios brasileiros do tempo máximo para atendimento dos consumidores, sob pena de multa, cuja legislação passou a ser conhecia popularmente como "lei contra demora nas filas". Essa dinâmica ilustra a influência de diversos sistemas constituintes do macrossistema no meio ambiente do trabalho, sobretudo dos sistemas jurídico, econômico e social.

É preciso destacar que a "lei contra demora nas filas" restringe-se a apenas alguns estados e municípios. Naquelas localidades em que não se regulamentou o tempo de espera na fila, ainda é possível verificar trabalhadores nas agência submetidos a uma intensa carga de trabalho. E mesmo nos municípios e estados onde ocorreu a regulamentação não houve nenhuma política ou legislação para o equacionamento do contingente de bancários à demanda de cada localidade, providência que estaria, em tese, relegada ao campo das negociações coletivas e da fiscalização dos sindicatos. Logo, no campo da autonomia da vontade dos atores sociais envolvidos no pacto coletiva.

Jaime Leandro Bulos a Zaiden Geraige Neto ainda evidenciam o rigor das políticas consumeristas no setor bancário ao mencionarem diversos fatores a serem observados no atendimento dos clientes-consumidores, sob pena de caracterização de dano moral coletivo, dentre eles a qualidade e celeridade do atendimento do consumidor não preferenciais:

$\mathrm{O}$ atendimento junto às casas bancárias deve sempre visar a coletividade. Não há agência bancária individual. Seu atendimento deve ser adequado para portadores de deficiência física, gestantes e idosos, dispondo de meios de acessibilidade a atendimento preferencial, tais como caixas, assentos para espera em fila de atendimento, tudo isso sem prejuízo ou atraso no atendimento do consumidor que não se encaixe na condição de "preferencial" 363 .

\footnotetext{
${ }^{362}$ PAIVA, Cynthia Suennia Damasceno Lucena de; BORGES, Lívia de Oliveira. O ambiente de trabalho no setor bancário e o bem-estar. Psicologia em Estudo, Maringá, v. 14, n. 1, p. 57-66, jan./mar. 2009.

363 BULOS, Jaime Leandro; GERAIGE NETO, Zaiden. Breves considerações sobre a possibilidade de condenação por dano moral coletivo às instituições bancárias, quando prejudicado o cliente-consumidor: aspectos materiais e processuais. In: RIBEIRO, José Horácio Halfeld Rezende. (Coord.). Revista de Direito Bancário e do Mercado de Capitais, a. 15, n. 57, p. 13-27, jul/set. 2012.
} 
Por isso, ainda se verifica a adoção de medidas para aceleração do ritmo laboral e a ampliação da jornada de trabalho dos bancários para além da sexta hora diária, cujo limite é previsto no artigo 224 da Consolidação das Leis do Trabalho, excetuados aqueles que desempenham funções de direção, fiscalização, chefia e outros cargos de confiança, nos termos do parágrafo $2^{\circ}$ do mesmo dispositivo celetista. Prova disso é que reclamações trabalhistas intentadas contra instituições bancárias não raramente denunciam volumosas horas extraordinárias habituais impagas e trabalhadores adoecidos em razão do trabalho.

É inegável que a "lei contra demora nas filas" é um exemplo da tensão existente entre os interesses consumeristas e trabalhistas que, se não harmonizados, tendem a precarizar ainda mais o meio ambiente do trabalho, de modo a comprometer a saúde dos trabalhadores daquele contexto. Ao menos em um primeiro momento, a supremacia dos interesses econômicos aos sociais induz ao favorecimento do pleito consumerista, em detrimento das garantias dos trabalhadores. Significa dizer que, se os consumidores devem ser atendidos rapidamente, a primeira medida do empregador será acelerar o ritmo de trabalho e não elevar o contingente de trabalhadores para suprir a demanda no tempo prescrito pela legislação.

Evidentemente, essa precarização das condições de trabalho no setor bancário atinge atendentes e gerentes de contas, cujas funções exigem contato direto com o público e, por isso, são mais suscetíveis às cobranças e pressões tanto dos empregadores como dos próprios consumidores. Sentem mais os impactos das medidas de harmonização da relação de consumo bancária, pois são eles os responsáveis diretos pela celeridade e qualidade do atendimento, principalmente porque os consumidores não acessam facilmente as instâncias superiores da instituição, a quem cabe a organização da atividade, incluindo o equacionamento do contingente de trabalhadores à demanda local.

Ao demonstrar a influência do sistema cultural no meio ambiente do trabalho, um dos participantes deste estudo ainda lembrou que não são todos os clientes-consumidores que são esclarecidos ao ponto de entender quem deve ser o alvo das críticas e reclamações, sendo "muito comum na nossa sociedade a gente atirar no alvo errado; a gente aproveita para xingar o caixa bancário, o ascensorista, porque o sistema cultural é decisivo na missão do discernimento" (Participante: MT1).

O Sindicato participante desta pesquisa ainda ressaltou que a reclamação é instantânea em caso de demora no atendimento e são dirigidas diretamente aos bancários: 
Formou fila ali na frente, no caixa, já se sabe que aconteceu alguma coisa errada. Não se sabe se a pessoa está ali com 15 ou 20 documentos pra serem resolvidos na hora lá. Mas quem está lá na fila já começa a questionar. E isso gera uma pressão muito grande. O próprio banco cobra muito isso. E tem um outro fator que gera mais problema psicológico que é o fator de lidar com dinheiro. Temos ainda, em se tratando de banco, o risco de um assalto. Tudo isso é complicado e reflete nas condições de trabalho. (Participante: Sindicato).

Portanto, não se duvida que essa tensão de interesses e a desconsideração da subjetividade do trabalhador, incluindo seus aspectos psicológicos e comportamentais que também integram o locus laboral, contribuem para o desequilíbrio do meio ambiente do trabalho, podendo repercutir negativamente na saúde do trabalhador. Tanto é que, no caso dos teleoperadores, o item 5.4.5 do Anexo II da NR 17 garantiu pausas imediatas após chamadas em que houver ocorrido ameaças, abusos verbais, agressões ou que tenham sido especialmente desgastantes; e o item 5.2.1 previu o dever das empresas de telemarketing equacionarem o contingente de teleoperadores à demanda em cada estabelecimento, para garantir que todos possam usufruir das pausas e intervalos previstos, de modo a evitar sobrecarga de trabalho.

Esse exemplo chancela tanto a interdependência de aspectos presentes diretamente (aspectos microssistêmicos) ou não (aspectos macrossistêmicos) no meio ambiente do trabalho, como também a interdependência de aspectos pessoais e ambientais, um influindo no outro, tendentes a influenciar o equilíbrio do meio e, consequentemente, a saúde do trabalhador. É o caso dos mecanismos de harmonização da relação de consumo, que não integram diretamente o meio ambiente do trabalho, contudo, devem ser considerados como manifestações de protótipos gerais dos sistemas social, econômico, cultural e jurídico que, embora sejam mais amplos e distais, estabelecem padrões para as estruturas e atividades que ocorrem no nível concreto, ou seja, no contexto laboral. Por isso, há que se harmonizar as políticas consumeristas com o direito fundamental dos trabalhadores a um trabalho digno, sob pena de comprometer o equilíbrio do meio ambiente do trabalho e a saúde daqueles que dele fazem parte. 


\section{CONSUMO E TRABALHO: IMPACTOS NO MEIO AMBIENTE DO TRABALHO E NA SAÚDE DO TRABALHADOR}

\subsection{A interdependência entre consumo e trabalho e seus impactos no contexto laboral}

O regramento consumerista e as políticas de harmonização da relação de consumo instituídas pelo Poder Público possuem duplo caráter: social e econômico. Eles também buscam equilibrar as forças antagônicas da relação de consumo, a fim de resguardar direitos e garantias do consumidor. Ao mesmo passo, repercutem na economia de um sistema que tem suas bases fincadas no consumo e na acumulação de riquezas.

A relação consumo e trabalho não se estreita apenas na semelhança entre institutos do Direito do Trabalho e do Direito do Consumidor e no caráter social e protetivo desses ramos jurídicos. Essas searas jurídicas são essencialmente interdependentes, não apenas porque Direito é sistema, mas, inclusive, porque o núcleo de cada uma dessas duas áreas, trabalho e consumo, são elementos inerentes ao sistema produtivo.

Consumo e trabalho são influenciados pelos elementos macrossistêmicos, quais sejam, pelos sistemas econômico, social, jurídico, político e cultural, como protótipos gerais que estabelecem padrões para estruturas e atividades que ocorrem no plano concreto ${ }^{364}$.

À guisa de exemplo, as recentes políticas econômicas de redução do imposto sobre produtos industrializados (IPI) não apenas aquecem o mercado de consumo e, consequentemente, a economia em situação de crise, mas também favorecem a geração de empregos contribuindo para a efetivação do direito fundamental ao trabalho. Nesse caso, os impactos são vantajosos.

Outro exemplo da interdependência benéfica é a grande quantidade de materiais recicláveis descartados no meio ambiente em razão do estímulo capitalista ao excesso de consumo justifica a atividade profissional dos catadores, cujo trabalho atualmente tem um papel fundamental, colaborando tanto na concretização dos princípios da ordem econômica da

364 BRONFENBRENNER, Urie. Toward an experimental ecology of human development. American Psychologist, Washington, v. 32, p. 513-531, 1977. 
Defesa do Meio Ambiente e da Busca do Pleno Emprego como na efetivação dos direitos ao trabalho e à dignidade, através do estímulo à organização da classe e da possibilidade desses trabalhadores alcançarem melhores condições de vida por meio dessa atividade profissional favorecida pelo consumo.

Assim sendo, trabalho e consumo atendem às necessidades humanas de alimentação, vestuário, saúde, habitação e lazer, entre outras, embora seja sabido que, nos novos tempos, o consumo deixou de apenas atender às necessidades primárias e se tornou o principal motor da economia, assumindo caráter patológico em algumas situações da sociedade moderna, denominado por consumismo.

Porém, é o trabalho que garante a manutenção da vida, possibilitando o consumo tanto de bens essenciais como supérfluos, ainda que se observe a inversão dessa ordem natural pela sociedade moderna. Consome-se mais e, para pagar os dívidas do consumismo, trabalhase mais ainda. Nesse caso, a necessidade insana do consumo vem antes mesmo da necessidade do trabalho.

A tensão entre interesses econômicos e sociais também se impõe tanto na relação de consumo como na relação de trabalho, havendo ainda uma interdependência desses interesses tanto dentro de cada uma dessas relações como entre uma e outra. Se para o crescimento econômico o investimento é fundamental, para o desenvolvimento social há que se viabilizar não apenas o acesso aos bens materiais, mas também aos serviços de saúde e ao trabalho, pois são eles que garantem o retorno do investimento econômico. A melhoria das condições de vida, nela incluídas as condições de trabalho, não está necessariamente na esfera do mercado de consumo. Por isso, não há que se falar em consumo como um dos principais elementos do desenvolvimento social, sobrepondo-o ao trabalho. Este sim, desde que em condições dignas e adequadas, importa em cidadania, dignidade, desenvolvimento, melhoria das condições de vida, justiça social e, inclusive, possibilita o acesso aos bens de consumo.

A interdependência entre trabalho e consumo também possui desvantagens, sobretudo nos casos em que a legislação não se apropria da sua função sistematizadora e harmonizadora. É o caso da antinomia entre o Decreto $n^{\circ} 6.523 / 08$ e o Anexo II da NR 17, cujo conflito pode favorecer a precarização das condições de trabalho no contexto de telemarketing. 
Enquanto o Decreto $\mathrm{n}^{\mathrm{o}}$ 6.523/08 impôs tempo máximo para a duração da transferência de ligações e de solução para as reclamações, acelerando o ritmo de trabalho sem prejuízo do dever de objetividade e clareza das informações, o Anexo II da NR 17 garantiu o aumento de pausas fora do posto de trabalho, a proibição de aceleração do trabalho e vetou a adoção de mecanismos de monitoramento da produtividade. Significa dizer que o Decreto $\mathrm{n}^{\circ}$ 6.523/08, aprovado cerca de um ano após o Anexo II da NR 17, privilegiou os consumidores em detrimento das precárias condições de trabalho vivenciadas pelos teleoperadores e reconhecidas no referido Anexo.

É certo que essa antinomia pode ser considerada apenas aparente, pois o Anexo II da NR 17 previu o dever dos empregadores equacionarem o contingente de teleoperadores em cada estabelecimento à demanda. Porém, essa previsão já existia antes mesmo do advento do Decreto $\mathrm{n}^{\circ} 6.523 / 08$ e não se viu qualquer medida política ou fiscalizatória que buscasse efetivar esse equacionamento. Como resultado, conforme afirmou o Sindicato entrevistado, houve sobrecarga do contingente de teleoperadores que já se encontravam em atividade.

Com isso, não houve benefício para nenhum dos atores desse contexto, conforme evidenciou um dos participantes deste estudo, ao apontar que, se os teleoperadores foram prejudicados com a limitação do tempo de atendimento e solução das reclamações, os consumidores perderam em relação à qualidade da prestação:

No meu entender, não houve benefício para nenhuma das partes. Não consigo ver um benefício, até porque ao instituir mecanismos de monitoramento da produtividade, o empregador favorece o consumidor na prestação de um atendimento de qualidade. E o aumento de pausas beneficia o empregado, proporcionando um descanso para a prestação de um trabalho com qualidade. Não vejo quem foi mais beneficiado. (Participante: MT2).

O Sindicato entrevistado ainda enfatiza a ausência de benefícios para consumidores, que não terão um atendimento adequado; para os empregados, com o desgaste em razão das cobranças e conflitos; e para os empregadores, em razão da insatisfação dos consumidores com a prestação e do esgotamento de seus empregados, tendente ao adoecimento:

Há uma coisa que precisa ficar clara pra todo mundo, inclusive para o próprio cliente. Se ele for atendido muito rapidamente ele não vai ter como ser bem atendido. Isso precisa ficar claro para o cliente. E dependendo do que esse cliente está questionando, do que está buscando, ele já liga pra lá como se o atendente que está do outro lado fosse a pessoa responsável pelo 
problema que ele está tendo. E ele descarrega sobre essa pessoa aquela insatisfação dele. E é muito difícil essa pessoa fazer esse atendimento com toda calma, passando tranquilidade e ainda fazer um trabalho bem feito para que o cliente saia daquela ligação satisfeito. Imagine só, você faz um atendimento sob essa pressão, faz outro, faz outro... chega uma hora, a pessoa acaba realmente até não querendo ser mal educado, nem grosso com a pessoa que está do outro lado da linha, mas acaba perdendo um pouco a compostura. E isso gera para o trabalhador uma série de problemas, uma série de dificuldades para continuar o trabalho. Porque a empresa não vê a sobrecarga que a pessoa está sentindo e o lado emocional acaba ficando de lado, mas, como todo ser humano, chega uma hora que o emocional às vezes extrapola e a pessoa acaba perdendo a compostura, o que não deveria acontecer, porém a gente deve entender que essa pressão é muito grande. (Participante: Sindicato)

Portanto, diante da interdependência já sustentada, ainda que os interesses trabalhistas e consumeristas devam coexistir harmonicamente, é possível que esses interesses se abalroem, produzindo impactos negativos nos dois contextos.

Para Jorge Cavalcanti Boucinhas Filho, a sobreposição dos direitos do consumidor aos direitos do trabalhador é destacada em diversas fontes e ocorre porque é o consumidor quem paga a conta da produção e dele também provém o lucro do negócio. Contudo, explica o jurista, que quantitativamente a massa consumidora é composta por empregados e trabalhadores informais, motivo pelo qual o papel dos trabalhadores na relação de produção não se limita apenas ao uso de sua força de trabalho, mas também a sua capacidade de consumir produtos, inclusive aquele que de alguma forma ajuda a produzir. Por isso, a estreita relação entre consumo e renda e entre trabalho e consumo. ${ }^{365}$

Jorge Cavalcanti Boucinhas Filho ainda evidencia a prevalência dos direitos do consumidor, ao destacar que "o trabalhador quando ingressa em uma loja para comprar o produto que ajudou a elaborar recebe melhor tratamento e maior proteção legal e judiciária do que quando trabalhava no processo de manufatura do mesmo item" ${ }^{366}$. E se a tensão é entre um consumidor e um trabalhador, o cliente sempre terá razão.

$\mathrm{Na}$ presente abordagem, um dos aspectos negativos apontados diz respeito aos impactos desse conflito no meio ambiente do trabalho, tendente a precarizar as condições

\footnotetext{
${ }^{365}$ BOUCINHAS FILHO, Jorge Cavalcanti. Tutela judicial e movimentos grevistas: um estudo sobre a atuação dos órgãos do poder judiciário diante das novas formas de manifestação coletiva dos operários. 2012. 276 f. Tese (Doutorado em Direito) - Faculdade de Direito, Universidade de São Paulo, São Paulo, 2012.

366 Ibidem, p. 13.
} 
laborais em telemarketing e influir na saúde dos trabalhadores desse contexto, considerando a interdependência entre meio ambiente do trabalho e os sistemas que compõem o que aqui se denominou como macrossistema.

Diante de um conflito entre interesses trabalhistas e consumeristas que imponha dificuldades na efetivação de direitos e garantias, cabe analisar qual deles prevalece em relação ao outro. E não será difícil a resposta.

Sabe-se que, no Direito brasileiro, existe uma rígida construção do ordenamento jurídico que dispõe as normas jurídicas em grau hierárquico escalonado e estático. Assim, as normas são dispostas de forma escalonada hierarquicamente, assumindo uma estrutura piramidal, encontrando-se em seu ápice a norma fundamental, da qual todas as outras normas dependem e retiram sua eficácia e validade ${ }^{367}$, assumindo a seguinte estrutura edificada em três grupos a seguir apresentados em ordem decrescente: Normas Constitucionais (Constituição Federal, Atos das Disposições Constitucionais Transitórias, Emendas Constitucionais, Tratados e Convenções sobre Direitos Humanos), Normas Infraconstitucionais (Lei Complementar, Lei Ordinária, Lei Delegada, Medida Provisória, Decreto Legislativo, Resolução e Tratado Internacional em geral) e Normas Infralegais (Decretos, Portarias e Instruções Normativas).

Nessa estrutura, o Decreto $n^{\circ}$ 6.523/08 do Ministério da Justiça estaria em posição hierarquicamente superior à Portaria $n^{\circ}$ 9/2007 do Ministério do Trabalho e Emprego, que instituiu o Anexo II da NR 17.

Todavia, além das especificidades das fontes do Direito do Trabalho (Constituição Federal, Lei, Regulamentos Normativos, Tratados e Convenções Internacionais, Sentenças Normativas, Costumes, Convenções e Acordos Coletivos de Trabalho), a despeito dessa regra geral, a matéria comporta exceções, como a hierarquia das normas no Direito do Trabalho, no qual se despreza o critério estático e escalonado de disposição normativa estabelecido pelo Direito Comum. Por força do Princípio da Norma mais favorável ao Trabalhador, um dos pilares do Princípio Proteção, a norma hierarquicamente superior será aquela mais favorável ao obreiro, independentemente do aspecto formal de sua produção.

\footnotetext{
${ }^{367}$ BOBBIO, Norberto. Teoria do Ordenamento Jurídico. 10. ed. Brasília: Editora Universidade de Brasília,
} 1999. 
Segundo Maurício Godinho Delgado “o vértice da pirâmide normativa, variável e mutável - ainda que apreendido segundo um critério permanente - não será a Constituição Federal ou a lei federal necessariamente, mas a norma mais favorável ao trabalhador, ${ }^{, 368}$, como forma de efetivação da proteção ao hipossuficiente da relação de emprego.

Logo, na seara laboral, diante de um conflito entre o Decreto $\mathrm{n}^{\circ} 6.523 / 08$ do Ministério da Justiça e a Portaria no 9/2007 do Ministério do Trabalho e Emprego, subsiste a última por ser mais favorável ao trabalhador, devendo o empregador primar pelo equilíbrio do meio ambiente do trabalho e pela saúde dos trabalhadores, buscando eliminar ou reduzir os riscos da atividade conforme o mandamento constitucional insculpido no art. $7^{\circ}$, inciso XXII. Além disso, o direito ao trabalho, à dignidade e à saúde, espécies de direitos humanos, garantem a supremacia do Anexo II da NR 17, instituído pela Portaria n $^{\circ}$ 9/2007 do Ministério do Trabalho e Emprego. Essa norma regulamentadora nada mais é que um instrumento de efetivação desses direitos fundamentais que prevalecem em relação a qualquer outro direito, inclusive ao direito do consumidor a um atendimento célere e adequado.

Evidentemente, o ideal seria que a legislação cumprisse sua função sistematizadora, imprimindo unidade e coerência ao sistema jurídico e primando pela harmonização dos interesses dos trabalhadores e consumidores, sobretudo porque ambos se situam no campo dos direitos sociais, influenciam-se reciprocamente e repercutem nos sistemas social e econômico.

Para Noberto Bobbio, o sistema jurídico é uma totalidade ordenada não apenas relacionada com o todo, mas coerente entre $\mathrm{si}^{369}$. Daí a necessidade de harmonização, como um processo que permite reconciliar os diversos ramos que compõem o sistema jurídico, sem desprezar as particularidades inerentes a cada um deles, considerando sua interdependência sistêmica e a necessidade de adaptação do Direito à complexidade de uma sociedade que se reinventa a cada tempo.

Direito e sociedade também são interdependentes, devendo o sistema jurídico considerar a intersubjetividade, a complexidade e a flexibilidade do processo evolutivo humano e social, sem se desgarrar dos aspectos sociológicos, econômicos, políticos e históricos para responder às angústias da sociedade. Por isso, a sistematização do meio

\footnotetext{
${ }^{368}$ DELGADO, Maurício Godinho. Curso de Direito do Trabalho. 8. ed. São Paulo: LTr, 2009. p. 166.

${ }^{369}$ BOBBIO, Norberto. Teoria do Ordenamento Jurídico. 10. ed. Brasília: Editora Universidade de Brasília, 1999.
} 
ambiente do trabalho proposta neste estudo considera a interdependência tanto de aspectos ambientais e pessoais no equilíbrio ambiental, como a interdependência do microssistema laboral e dos sistemas social, econômico, político, cultural e jurídico que compõem o macrossistema, para a efetivação do direito fundamental ao meio ambiente do trabalho equilibrado e da saúde do trabalhador.

Assim sendo, considera-se que o Anexo II da NR 17 cumpriu sua função harmonizadora ao equacionar interesses econômicos e sociais, prevendo em seus itens $5.2 \mathrm{e}$ 5.2.1 o dever das empresas do setor equacionarem o contingente de teleoperadores em cada estabelecimento à demanda, para garantir que todos possam usufruir as pausas e intervalos previstos, evitando sobrecarga de trabalho e a precarização da qualidade da prestação do serviço aos consumidores. Já o Decreto $\mathrm{n}^{\circ}$ 6.523/08, posterior ao referido Anexo, sequer mencionou a necessidade desse equacionamento ou sugeriu qualquer proporcionalidade entre posições de atendimento e demanda. Cobrou-se mais qualidade de atendimento e menos observância dos parâmetros mínimos de segurança e conforto para o desempenho da atividade.

Como os "lírios não nascem da lei",370, cabe a todos os atores sociais envergarem esforços para que os direitos sociais não sejam sufocados pelos interesses econômicos; para que os direitos fundamentais ao meio ambiente do trabalho equilibrado, à saúde, à dignidade e ao trabalho sejam efetivados e não tratados como empecilhos para o desenvolvimento econômico; e para que o Anexo II da NR 17, bem como tantos outros dispositivos atinentes à matéria saúde e segurança no trabalho, sejam observados como instrumentos de redução dos riscos inerentes à atividade e ao locus laboral, sem prejuízo de outras intervenções que busquem neutralizá-los, nos termos do mandamento constitucional contido no art. $7^{\circ}$, inciso XXII.

\subsection{A atuação dos atores sociais na efetivação do direito à saúde e ao meio ambiente do trabalho equilibrado: uma integração necessária}

O campo da saúde do trabalhador é um espaço de complementação. Além da contribuição de diversas áreas do conhecimento, requer o engajamento de diversos atores sociais, incluindo os próprios trabalhadores, empregadores e tomadores, para a concepção, A rosa do povo. 21. ed. Rio de Janeiro: Record, 2000. p. 29-37. 
instituição, implementação e fiscalização de medidas que garantam melhores condições de trabalho e de vida, pautadas na dignidade do trabalhador e na adequabilidade da organização, dos instrumentos e do meio ambiente do trabalho.

No prefácio da obra de José Antonio Ribeiro de Oliveira Silva, Maurício Godinho Delgado esclarece que:

Ao fixar a saúde como um direito de todos, inclusive do trabalhador, e, dever do Estado e da sociedade, inclusive empregador e tomador de serviços, plasmando também a noção de meio ambiente laborativo, ideias que vinculou à diretriz da dignidade da pessoa humana, a Constituição da República abriu clarão transformador no cenário jurídico ${ }^{371}$.

Desse modo, os próximos tópicos ilustrarão como cada ator social pode contribuir para a efetivação desse direito, seja por meio da prevenção, da recuperação e reabilitação dos trabalhadores adoecidos ou da abstenção de determinadas práticas que possam lesar a saúde do trabalhador.

\subsubsection{O papel do empregador}

O empregador, como um dos principais atores da relação de emprego, possui papel fundamental na efetivação do direito à saúde do trabalhador. Detém o poder de direção da atividade e, por corolário, é responsável pelo equilíbrio do meio ambiente do trabalho, cujas condições influenciam, positiva ou negativamente, nos fatores pessoais e ambientais constituintes desse meio, à guisa do que propõe este estudo.

O dever do empregador não se limita ao pagamento de adicionais monetários (insalubridade, periculosidade, noturno e hora extraordinária) e no cumprimento das normas regulamentadoras expedidas pelo Ministério do Trabalho e Emprego que, em primeiro plano, não tiveram a ousadia de buscar a eliminação dos riscos laborais, mas tão somente de propor medidas para reduzi-los a níveis toleráveis. Não obstante, nos termos do mandamento constitucional prescrito no art. $7^{\circ}$, inciso XXII, a prioridade do empregador deve ser sempre a redução total (eliminação) do agente agressor à integridade do trabalhador, obrigando-se, alternativamente, nas circunstâncias em que isso não for tecnicamente possível, à diminuir

\footnotetext{
${ }^{371}$ SILVA, José Antônio Ribeiro de Oliveira. A saúde do trabalhador como um direito humano: conteúdo essencial da dignidade humana. São Paulo: LTr, 2008. p. 13.
} 
gradativa da intensidade do agente prejudicial em limites toleráveis (neutralização), observando-se o atual estágio da técnica e a capacidade econômica do empreendimento.

A abstenção a que está obrigado o empregador é tão ou mais importante do que a ação a que também se obriga ${ }^{372}$. Além do pagamento do seguro contra acidente de trabalho, da expedição de CAT, da constituição de CIPA, da obrigatoriedade de elaboração e implementação do PPRA e do PCMSO, da manutenção do SESMT, da informação dos trabalhadores sobre os riscos do trabalho e do local de trabalho, fornecimento e da fiscalização do uso de equipamentos de proteção individual e coletiva, da capacitação adequada dos trabalhadores, da concessão das pausas para repouso e alimentação e especiais, do equacionamento da quantidade de trabalhadores à demanda, da realização de exame médico (admissional, periódico, demissional, de retorno ao trabalho e de mudança de função), da manutenção do maquinário e do instrumentos profissionais e do cumprimento das normas de saúde e segurança no trabalho, deve o empregador se abster de algumas práticas que contribuam para a precarização das condições laborais e lesem o direito de seus trabalhadores à saúde.

À título exemplificativo serão apresentadas algumas abstenções às quais se obriga o empregador.

Deve o empregador abster-se da exigência de horas extraordinárias habituais, principalmente quando se tratar de atividades insalubres, perigosas e penosas, evitando a exposição demasiada de seus trabalhadores, incluindo os terceirizados, aos riscos inerentes ao trabalho e ao local de trabalho, sobretudo quando se tratar de trabalhadores ainda mais vulneráveis (por exemplo, gestantes, portadores ou predispostos a alguma doença). A prestação de serviço em sobrejornada tem sido fato muito corriqueiro no cenário laboral brasileiro, em detrimento da previsão celetista de que o labor extraordinário apenas poderia ser exigido excepcionalmente, extraordinariamente conforme mesmo apregoa a Consolidação das Leis do Trabalho.

Em relação ao contexto abordado neste estudo, o Anexo II da NR 17 positivou essa abstenção ao instituir em seu item 5.3.1 a admissibilidade da prorrogação da jornada de trabalho apenas no caso de necessidade imperiosa, sem prejuízo das pausas, respeitado o limite de trinta e seis horas semanais de tempo efetivo em atividade de telemarketing,

\footnotetext{
${ }^{372}$ SILVA, José Antônio Ribeiro de Oliveira. A saúde do trabalhador como um direito humano: conteúdo
} essencial da dignidade humana. São Paulo: LTr, 2008. 
recentemente considerada penosa pelo Tribunal Superior do Trabalho. Buscando ainda a redução da exposição desses trabalhadores aos riscos da atividade, o referido Anexo também ampliou a pausa para repouso e alimentação de 15 para 20 minutos, no caso de trabalhadores sujeitos à jornada de seis horas, e instituiu duas pausas especiais de dez minutos contínuos após os primeiros e antes dos últimos 60 minutos de trabalho, bem como uma pausa de descanso contínua de 10 minutos para trabalhadores sujeitos à jornada de quatro horas, não assistidos pelo art. 71, parágrafo $1^{\circ}$, da Consolidação das Leis do Trabalho.

Também deve o empregador abster-se da utilização de mecanismos de avaliação e monitoramento da produtividade que impliquem em aceleração do ritmo de trabalho ou pressão excessiva para o alcance de metas e resultados, que repercutam negativamente na saúde psicofísica dos trabalhadores. Isso porque tais práticas podem contribuir para o desencadeamento ou agravamento de diversas doenças, sobretudo mentais, como é o caso do estresse, depressão ou síndrome do esgotamento nervoso.

José Antônio Ribeiro de Oliveira Silva assevera que o campo da ergonomia apresenta estreita relação com a fadiga, desencadeada por condições inadequadas de trabalho ou pela exigência de trabalho superior às forças psicofísicas do trabalhador ${ }^{373}$. Por isso, pontuou bem o item 5.9 do Anexo II da NR 17 ao proibir a utilização de mecanismos de monitoramento da produtividade (por exemplo, mensagens nos monitores de vídeo, sinais luminosos, cromáticos, sonoros, ou indicações do tempo utilizado nas ligações ou de filas de clientes em espera, entre outros), que visem à aceleração do ritmo de trabalho.

Não se deve esquecer que tensões e atritos entre consumidores e trabalhadores, sobretudo quando há ameaças, abusos ou agressões verbais, se constantes ou especialmente desgastantes, podem contribuir para o adoecimento mental dos trabalhadores, motivo pelo qual previu o item 5.16 do Anexo II da NR 17 o dever do empregador conceder pausas no trabalho imediatamente após atendimentos marcados por essas situações. Nesse caso, não se trata de uma abstenção a que está obrigado o empregador, mas sim de uma ação, uma conduta positiva. Contudo, não deve o empregador se abster de adaptar o meio ambiente laborativo, nele compreendida a organização do trabalho, ao ser humano e não o contrário, buscando ainda evitar ou harmonizar possíveis conflitos entre empregados e desses com clientesconsumidores, por meio de minimização da ambiguidade de papéis nas tarefas a executar, de

\footnotetext{
${ }^{373}$ SILVA, José Antônio Ribeiro de Oliveira. A saúde do trabalhador como um direito humano: conteúdo essencial da dignidade humana. São Paulo: LTr, 2008.
} 
diretrizes claras quanto a ordens e instruções de diversos níveis hierárquicos, da autonomia para resolução de problemas e da consulta a colegas de trabalho, conforme previu o item 5.14 do Anexo II da NR 17.

Evidentemente, deve ainda se abster da utilização de métodos que causem assédio moral, medo ou constrangimento, como por exemplo, empregar estímulo abusivo entre trabalhadores, grupos ou equipes de um mesmo ou de diferentes estabelecimentos; exigir o uso de adereços, acessórios, fantasias e vestimentas com o intuito de punição, promoção, propaganda ou escárnio; instituir metas incompatíveis e de difícil alcance; expor publicamente as avaliações de desempenho; considerar afastamentos por doença do trabalho na avaliação de desempenho como fator impeditivo para ascensão de cargo, para efeito de remuneração ou vantagens de qualquer espécie, entre outras práticas.

Todavia, o que se vê é uma cultura que enxerga os valores sobre saúde e doença construídos na empresa sob o foco da produtividade, pois quanto menor for o comprometimento com a saúde dos trabalhadores, maior a possibilidade dessas questões de saúde-doença serem ignoradas por eles mesmos ${ }^{374}$.

Deve o empregador engajar-se na efetivação do direito à saúde, apropriando-se do seu papel junto a seus próprios empregados e aos demais atores do contexto laboral, incluindo os sindicatos profissionais e econômicos, sem esperar que o Estado protagonize solitariamente a efetivação desse direito humano. Nesse sentido, esclarece Sebastião Geraldo Oliveira:

É mais inteligente, ético e econômico adotar programas de prevenção, de higiene, de qualidade de vida no trabalho e garantir um ambiente saudável com alta produtividade, em vez de enfrentar constantes insatisfações profissionais com volume crescente de ações judiciais, postulando indenizações por danos civis, inclusive por danos morais, decorrentes do estresse $^{375}$

Portanto, afora a observância das normas de saúde e segurança no trabalho, um dos caminhos é o planejamento e instituição de ações voltadas para a promoção de uma cultura de saúde e segurança dentro do próprio meio laboral, buscando a todos conscientizar que um meio ambiente do trabalho equilibrado não apenas agrega valores à vida do

374 LIMONGI-FRANÇA, Ana Cristina; RODRIGUES, Avelino Luiz. Stress e trabalho: uma abordagem psicossomática. 3. ed. São Paulo: Atlas, 2002.

${ }_{375}$ OLIVEIRA, Sebastião Geraldo. Proteção jurídica à saúde do trabalhador. 4. ed. São Paulo: LTr, 2002. p. 207. 
trabalhador, mas também à atividade empresarial. Isto porque tanto os interesses econômicos e sociais como o meio ambiente do trabalho e os demais contextos ambientais são essencialmente interdependentes e, por isso, influenciam-se.

\subsubsection{O papel dos sindicatos}

$\mathrm{O}$ art. 225, caput, da Constituição Federal estabelece o dever concorrente do Poder Público e da coletividade na defesa e preservação do meio ambiente, competindo ao sindicato, como parte da sociedade organizada, o dever de defender os direitos e interesses coletivos e individuais da categoria, nos termos do art. $8^{\circ}$, inciso III, da Constituição Federal.

Ao contrário do empregador, o campo de atuação dos sindicatos prevê mais ações, já que as abstenções se limitam às condutas antissindicais.

Dentre as ações, deve o sindicato reservar maior atenção aos benefícios e cláusulas sociais nos acordos e convenções coletivas de trabalho, haja vista que a negociação coletiva é um terreno fértil e propício para dispor sobre condições ambientais do trabalho, proibir certas práticas institucionais que comprometam a saúde do trabalhador e instituir medidas preventivas que contribuam para a eliminação de agentes agressores à integridade do trabalhador, efetivando o mandamento constitucional insculpido no art. $7^{\circ}$, inciso XXII. Pouco se utilizam desse importante instrumento de tutela do meio ambiente do trabalho, construído pelos e para os próprios atores do contexto laboral, característica que permite à negociação coletiva um olhar mais pontual para os anseios, necessidades e riscos específicos de cada atividade; em suma, para as peculiaridades do meio ambiente do trabalho de cada atividade.

Contudo, os sindicatos ainda não se conscientizaram da importância do meio ambiente do trabalho seguro como arena e motor da preservação da saúde psicofísica do trabalhador, razão pela qual ainda não avançaram na defesa desse direito, ainda que legitimados pela Constituição Federal, conforme os artigos $8^{\circ}$, inciso III e 129, parágrafo $1^{\text {o376; }}$ preferem encaminhar denúncias ao Ministério do Trabalho e Emprego e ao Ministério Público do Trabalho a ajuizar ação coletiva, mesmo havendo interesse e provas suficientes.

\footnotetext{
${ }^{376}$ MELO, Raimundo Simão de. Direito ambiental do trabalho e a saúde do trabalhador: responsabilidades legais, dano material, dano moral, dano estético, indenização pela perda de uma chance, prescrição. 4. ed. São Paulo: LTr, 2010.
} 
Vê-se, pois, que pouca atenção é dada às ações preventivas, sobretudo em sede de negociação coletiva. A título de exemplo, na Convenção Coletiva que abrange a categoria profissional de trabalhadores em telecomunicações referente ao biênio 2011/2012, embora constituída por 66 cláusulas há apenas 3 que versam sobre o assunto; uma trata do uso de uniforme, higienização de instrumentos e uso e fornecimento de equipamentos de proteção individual (cláusula trigésima terceira); e outras duas repetem o óbvio: o dever de aplicar a garantia legal ao trabalhador afastado por acidente ou doença (cláusula trigésima quarta) e a obrigação das empresas informarem seus trabalhadores sobre a inadmissão de qualquer prática de assédio moral (cláusula trigésima quinta).

Outro ponto que desperta atenção é a parca informação que é prestada pelos sindicatos à categoria profissional. Por exemplo, no próprio sítio eletrônico do Sindicato dos Trabalhadores em Telecomunicações no Estado de São Paulo a convenção coletiva da categoria não se encontra disponível para consulta, sendo necessário que os trabalhadores adquiram uma cópia do instrumento, mediante o pagamento de um valor pré-estabelecido. Trata-se de uma condição inusitada, haja vista a convenção ser o resultado da negociação coletiva dos direitos dos próprios trabalhadores.

As ações de saúde e segurança no trabalho em telemarketing são desenvolvidas prioritariamente pelo Sindicato da capital, o que pode comprometer sua efetivação nas bases territoriais do interior do estado. Contudo, deve-se reconhecer que, em relação ao conteúdo do Anexo II da NR 17, andou bem o referido sindicato ao confeccionar e distribuir para os teleoperadores de todo o estado de São Paulo uma cartilha sobre os principais pontos desse anexo, atentando-se para o dever de informar (do sindicato) e para o direito de ser informado (do trabalhador).

Todos os participantes deste estudo apontaram a tímida atuação sindical, mencionando a inexistência de uma cultura sindical no Brasil que preconize ações coletivas ao invés de ações individuais quase sempre pautadas em interesses econômicos, conforme apontam os recortes a seguir colacionados:

Na verdade, a procuradoria não atua quando há sindicato representativo da categoria. E os sindicatos preocupam-se mais com a questão econômica; basta olhar um acordo ou convenção coletiva para constatar isso. Não se vê empenho! Em não raras vezes, a Procuradoria e o Sindicato seguem na contramão dos interesses e da vontade dos próprios empregados representados. (Participante: MT8). 
Eu não peguei ainda nenhuma situação em que sindicato tivesse à frente. $\mathrm{E}$ são comuns as ações que reproduzem os mesmos questionamento. Então eu identifico nisso problemas que são generalizados e que demandariam sim uma atuação mais incisiva dos sindicatos. Mas não vemos. Ação coletiva é algo que, pelo menos, ainda está longe de ser uma cultura prática. A gente não percebe, muitas vezes a gente "provoca", levanta a questão nas oportunidades possíveis, mas não se vê retorno algum. Eu não me recordo de nenhum caso de atuação de índole coletiva dentro dessa temática. Não tive essa experiência! (Participante: MT3).

Prova disso é que, em consulta ao sítio eletrônico do Sindicato dos Trabalhadores em Telecomunicações no Estado de São Paulo, encontram-se arroladas apenas as seguintes ações coletivas, todas de natureza econômica: Ação Coletiva de Expurgos Inflacionários em face da SISTEL (Processo no 20040110381722 e Execução no 20110110931499 - 14 ${ }^{\text {a }}$ Vara Cível de Brasília); Ação Coletiva de Expurgos Inflacionários em face da TELOS (Processo ${ }^{\circ}$ 20060010095093 - 18 $8^{a}$ Vara Cível do Rio de Janeiro); Ação Coletiva de Repetição de Indébito de Imposto de Renda sobre Contribuições Pessoais entre 1989 a 1995 (Processo ${ }^{\circ}$ 200534000101915 - 5 $5^{\text {a }}$ Vara Federal de Brasília); Ação Coletiva sobre a ilegalidade da cobrança de contribuição previdenciária sobre rubricas trabalhista (Processo $\mathrm{n}^{\circ}$ $00702188720114013400 \quad-3^{\mathrm{a}}$ Vara Federal de Brasília); Ação Coletiva de inconstitucionalidade do fator previdenciário (Processo $\mathrm{n}^{\mathrm{o}} 00473118420124013400-20^{\mathrm{a}}$ Vara Federal de Brasília; e Ação Coletiva de anulação da distribuição do superávit (a ajuizar) $^{377}$.

As ações coletivas poderiam contribuir potencialmente na garantia de melhores condições de trabalho, na manutenção do equilíbrio do meio ambiente do trabalho e na instituição de medidas promotoras de saúde que possam garantir qualidade de vida dentro e fora do trabalho. Não se trata apenas dos casos em que deve o sindicato cobrar o cumprimento das normas de saúde e segurança no trabalho quando ignoradas pelo empregador, mas também das circunstâncias em que deve a entidade sindical se utilizar desse instrumento processual para coibir o empregador a se abster de certas práticas que comprometam o equilíbrio do meio ambiente do trabalho e a saúde do trabalhador. Há empresas que regularmente são condenadas a indenizar trabalhadores submetidos a práticas abusivas ou assediantes, não havendo qualquer ação mais incisiva do sindicato, sobretudo por meio de

${ }^{377}$ SINDICATO DOS TRABALHADORES EM TELECOMUNICAÇÕES NO ESTADO DE SÃO PAULO. Departamento Jurídico: Ações Coletivas. Disponível em: 〈http://www.sintetel.org/novo/acoes_coletivas.php〉. Acesso em: 30 out. 2012. 
ações coletivas, buscando melhorias das condições de trabalho sem reflexos econômicos diretos.

Quanto à atribuição fiscalizatória, o Sindicato entrevistado apontou a insuficiência de funcionários para essa finalidade no quadro funcional da entidade e a resistência das empresas do setor como obstáculos para a fiscalização, nos termos imprimidos no seguinte recorte:

\begin{abstract}
Normalmente, as pessoas vem reclamar quando a coisa fica muito difícil e você não consegue solucionar na própria empresa. A gente tem questionado, tem passado essas informações para o Ministério do Trabalho e todas as vezes que procuramos temos sido atendidos. Assim como o sindicato, o Ministério do Trabalho também tem pouca gente para fazer esses atendimentos. Então, as coisas às vezes se tornam um pouco mais complicadas. Você espera uma visita para 2 ou 3 dias e essa visita acaba acontecendo em 15 dias. Mas o importante é que eles vão em 15 dias e acabam de repente pegando algumas coisas erradas, assim como quando o sindicato vai.

A gente começa a acompanhar mais de perto as empresas com mais de 50 empregados, inclusive porque há a necessidade de composição de CIPA que é obrigatório por lei.
\end{abstract}

Cabe observar que a fiscalização é uma das medidas fundamentais na defesa do meio ambiente do trabalho. Por isso, deve ser desempenhada não apenas pelo Ministério do Trabalho e Emprego, mas também sindicato, a quem incumbe a defesa dos direitos e interesses coletivos ou individuais da categoria, sob pena de sobrecarregar ainda mais o Poder Público que, evidentemente, é incapaz de atender sozinho à demanda de todas as categorias profissionais.

A defesa do meio ambiente do trabalho encontra dois entraves. Um deles é a inexistência de ações preventivas pautadas numa cultura de saúde e segurança no trabalho por parte de todos os atores envolvidos na questão. $\mathrm{O}$ outro diz respeito à precária fiscalização das condições laborais, inclusive do meio ambiente do trabalho, e do cumprimento das normas trabalhistas e de saúde e segurança, que colocam em risco até mesmo os direitos fundamentais dos trabalhadores, como o direito à vida, ao trabalho, à saúde, à dignidade e ao meio ambiente do trabalho equilibrado.

Mal aparelhada e pouco apoiada pelo Poder Público, a fiscalização do trabalho no país ainda é insuficiente, favorecendo o mal empregador, que conta com a impunidade, pois sabe que o Estado não consegue fiscalizar a todos, tampouco com frequência, nem considera 
isso prioridade ${ }^{378}$. Daí a importância da fiscalização pelo sindicato como forma de suprir tal deficiência do Poder Público.

Por fim, os sindicatos tem a sua disposição dois poderosos mecanismos para harmonizar interesses sociais e econômicos: a convenção coletiva de trabalho e a convenção coletiva de consumo; esta última ainda pouco conhecida. Por meio da integração desses instrumentos seria possível, por exemplo, adequar a atividade à demanda e conciliar interesses econômicos e sociais, evitando sufocar direitos e garantias e favorecer a prevalência da gana capitalistas sobre os diretos sociais, até porque a prosperidade da economia depende da previsão e manutenção da suficiência desses direitos, sem os quais não se garante a sustentabilidade dos interesses econômicos. E é por isso que essa interdependência dos sistemas econômico e social é tão cara ao campo da saúde do trabalhador, justamente pela sua repercussão, ainda que indireta, no meio ambiente do trabalho.

\subsubsection{O papel do Estado}

A Constituição da Organização Mundial da Saúde considera fundamental o papel do Estado na efetivação do direito à saúde, ao reconhecer que "os governos tem responsabilidade pela saúde de seus povos, a qual só pode ser cumprida mediante a adoção de medidas sanitárias e sociais adequadas" ${ }^{, 379}$.

Por sua vez, a Constituição da República Federativa do Brasil de 1988, evidenciando a interdependência entre os sistemas político, social e econômico, reforçou o dever do Estado na efetivação do direito à saúde ao instituir, em seu art. 196, que "a saúde é direito de todos e dever do Estado, garantido mediante políticas sociais e econômicas que visem à redução do risco de doença e de outros agravos e ao acesso universal e igualitário às ações e serviços para sua promoção, proteção e recuperação".

Não se deve esquecer que a efetivação desse direito requer ainda a integração das funções administrativa, judiciária e legislativa do Estado, em todas as suas esferas a atribuições. Ademais, o Estado não deve apenas se abster de práticas que atentem contra a

\footnotetext{
${ }^{378}$ OLIVEIRA, Sebastião Geraldo. Proteção jurídica à saúde do trabalhador. 6. ed. São Paulo: LTr, 2011.

379 ORGANIZAÇÃO MUNDIAL DA SAÚDE. Constituición de La Organización Mundial de La Salud. Disponível em: <http://www.who.int/gb/bd/S/S_documents.htm>. Acesso em: 20 maio 2012.
} 
saúde do trabalhador, mas também se engajar em ações preventivas e reativas necessárias à promoção, recuperação e habilitação do estado de saúde.

Em que pese a função legislativa, as legislações em vigor no Brasil ainda deixam muito a desejar. De acordo com a Política Nacional de Segurança e Saúde do Trabalhador do Ministério do Trabalho e Emprego, o atual sistema de saúde e segurança do trabalhador carece de mecanismos adequados que estimulem a prevenção, o gerenciamento dos fatores de riscos ocupacionais, a responsabilização dos empregadores, o efetivo reconhecimento dos segurados e a diminuição de conflitos institucionais ${ }^{380}$.

Segundo Sebastião Geraldo de Oliveira, "as normas que tratam do assunto estão dispersas em vários dispositivos legais desconexos, abrangendo diversos ramos do direito, sem um consolidação adequada, o que dificulta o seu conhecimento, consulta e aplicação" 381 . Por isso, propõe o jurista a elaboração de um "Estatuto nacional de segurança e saúde do trabalhador", com o objetivo de sistematizar a legislação, despertar o interesse dos empregadores pelo assunto e contribuir para a melhoria da qualidade de vida do trabalhador.

Concordamos com a sugestão de Sebastião Geraldo de Oliveira, embora suspeitemos que uma das principais deficiências para a efetivação do direito à saúde é a ausência de fiscalização pelo Estado e de atualização das normas existentes, sobretudo das normas regulamentadores expedidas pelo Ministério do Trabalho e Emprego, o que será abordado mais adiante.

Por algum tempo, o Poder Legislativo preocupou-se mais com a instituição de adicionais monetários, embora pouca atenção tenha dado às atividades penosas, cujo adicional ainda não foi regulamentado não bastasse mais de vinte anos da promulgação da Constituição Federal de 1988, que previu em seu art. $7^{\circ}$, inciso XXIII, o direito do trabalhador ao recebimento de adicional de remuneração para as atividades insalubres, perigosas e, inclusive, penosas.

Não se quer dizer que a regulamentação desse adicional, por si só, seria a tábua de salvação para os trabalhadores submetidos a condições penosas de trabalho, pois, nos termos

\footnotetext{
${ }^{380}$ MINISTÉRIO DA SAÚDE. Política Nacional de Saúde do(a) Trabalhador(a): Proposta para Consulta Pública. Brasília. In: Portal da Saúde, Brasília, 2004. Disponível em: <http://portal.saude.gov.br/portal/ arquivos/pdf/proposta_pnst_st_2009.pdf>. Acesso em: 12 set. 2012.

${ }^{381}$ OLIVEIRA, Sebastião Geraldo de. Proteção Jurídica à saúde do Trabalhador. 6. ed. São Paulo: LTr, 2011. p. 135 .
} 
do art. $7^{\circ}$, inciso II, da Constituição Federal, deve-se buscar eliminar os riscos da atividade e do local de trabalho e, caso não seja possível, reduzi-los a níveis toleráveis. Os adicionais, contudo, não atendem a nenhuma dessas exigências, ainda que haja empregadores que sinalizem o atendimento das normas de segurança e saúde do trabalho alegando o pagamento desses adicionais, cuja visão monetiza a saúde do trabalhador.

É certo que o pagamento dos adicionais monetários deve ser observado, porém, sem prejuízo da adoção de práticas preventivas e reativas de saúde e da abstenção de condutas que lesem a saúde do trabalhador, buscando sempre a eliminação dos riscos inerentes ao trabalho, nos termos do mandamento constitucional.

Uma das medidas que poderiam ser mais largamente adotadas pelo Estado é a instituição de repousos adicionais e vedação de sobrejornada para atividades sujeitas a condições de trabalho insalubres e penosas, visando à diminuição da exposição dos trabalhadores aos riscos da atividade. É o que fez o Anexo II da NR 17, ao ampliar o tempo de intervalo para repouso e alimentação e instituir pausas especiais em benefício dos trabalhadores em telemarketing, cuja atividade foi recentemente reconhecida como penosa pelo Tribunal Superior do Trabalho. Em relação às atividades perigosas, nenhum proveito teria a instituição de repousos adicionais, em razão do risco potencial e do caráter inesperado e fulminante do evento.

Ainda não se pode esquecer a obrigação do Estado de expedir normas de saúde, higiene e segurança para a redução dos riscos laborais, sendo essa uma das atribuições que se encontram no campo da competência do Ministério do Trabalho e Emprego, nos termos do art. 87, inciso II, da Constituição da República. Todavia, embora o Brasil tenha uma das melhores normatizações no tocante a prevenção da saúde do trabalhador, atualizar as normas regulamentadoras é tão importante quanto editá-las. Isso porque, a cada tempo, os limites de tolerância são atualizados em relação aos agentes insalubres com base nos conhecimentos científicos adquiridos progressivamente, carecendo de atualização as normas regulamentadoras, nesse caso a NR 15, de modo a se ajustar aos novos limites e ao atual estado da técnica.

Por fim, cabe ao Estado sistematizar e harmonizar o ordenamento jurídico, evitando fomentar conflitos entre interesses econômicos e sociais que possam comprometer o equilíbrio do meio ambiente do trabalho e a saúde do trabalhador. Deve evitar a edição de 
normas antagônicas entre si, como fez em relação ao Decreto $\mathrm{n}^{\circ} 6.523 / 08$, que regulamentou o serviço de teleatendimento, instituindo limites temporais para o atendimento dos consumidores, enquanto a Portaria $n^{\circ}$ 9/2007, que instituiu o Anexo II da NR 17, já havia vedado a instituição de mecanismos voltados para a aceleração do ritmo de trabalho e para a cobrança incisiva de metas e resultados.

Quanto à função jurisdicional, ainda que o judiciário seja um poder inerte, portanto, sujeito à provocação, sua contribuição é de fundamental importância para a efetivação do direito à saúde e no estabelecimento de uma cultura de saúde e segurança no trabalho. Embora sua participação nesse processo não se limite a situações em que o dano já se consumou, ainda são poucas as ações coletivas ajuizadas pelos sindicatos pleiteando melhores condições laborais ou intervenções preventivas no meio ambiente do trabalho. Os pedidos indenizatórios são bem mais comuns e o caráter pedagógico da condenação é quase inexpressivo, submergindo à falácia da tese da "indústria do dano moral" que apenas interessa àquele que pretende persistir com os erros a promover dignidade no trabalho, transformando o discurso da efetivação dos direitos fundamentais em práticas de igual teor.

As condenações reparatórias por práticas perversas que repercutem na saúde do trabalhador nem sempre desestimulam as empresas à reincidência. Para alguns setores, como o telemarketing, é muito mais vantajoso correr o risco a rever a organização e as condições de trabalho, não sendo raro encontrar empresas do setor condenadas dezenas de vezes pela mesma prática e circunstância. Os bancos, por sua vez, resistem a discutir mecanismos de controle de produtividade e metas, sob a alegação de que fazem parte do poder econômico, negligenciam a interdependência entre os sistemas econômico e social.

Por isso, o papel do judiciário é também observar o caráter pedagógico da decisão jurisdicional, lembrando-se que razoabilidade e proporcionalidade do quantum indenizatório não significa arbitrar valores ínfimos, capazes de reforçar uma supremacia dos interesses econômicos em relação aos sociais e a prosperidade econômica em detrimento dos direitos fundamentais do trabalhador.

Devem também os demandantes cumular pretensões indenizatórias e pleitos obrigacionais, de fazer ou não fazer, como por exemplo: campanhas educativas intralaborais e em meios de comunicação; cartilhas informativas; palestras sobre saúde e segurança no trabalho; abstenção de certas práticas assediantes ou precarizadoras das condições de trabalho; 
substituição de equipamentos e/ou procedimentos, a afim de ajustar a atividade aos novos limites de riscos e ao atual estado da técnica; entre outras ações ou abstenções tendo em vista a defesa do meio ambiente do trabalho e da saúde do trabalhador.

Destaca-se, contudo, que o cumprimento da medida preventiva devida ou a cessação da atividade nociva independe de requerimento do demandante, podendo ser impingida de ofício pelo magistrado, nos termos do art. $11^{\circ}$ da Lei $n^{\circ} 7.347 / 85$, que disciplina a Ação Civil Pública de responsabilidade por danos causados ao meio ambiente, lembrandose, nele incluído o do trabalho sob a perspectiva sistêmica já elucidada. Nessa esteira, tem o sindicato as ações coletivas como um instrumento adequado para a defesa do meio ambiente e da saúde dos trabalhadores, tem o judiciário, a seu favor, o art. $11^{\circ}$ da Lei $\mathrm{n}^{\circ} 7.347 / 85$.

Considera-se a Certidão Negativa de Débitos Trabalhistas (CNDT), instituída pela Lei $\mathrm{n}^{\circ} 12.440 / 201$ e que exige a regularidade fiscal e trabalhista dos empregadores que pretendem se habilitar em licitações públicas para a celebração de contratos de fornecimento de bens e serviços ao Poder Público, uma importante conquista na construção de uma cultura de saúde e segurança no trabalho no meio empresarial. Além do adimplemento dos créditos trabalhistas, um dos seus propósitos, ainda que indireto, é o estímulo à observância dos direitos laborais, neles incluído o direito à saúde e segurança no trabalho, como forma de evitar demandas que possam culminar na inclusão no rol dos devedores trabalhistas e, por consequência, na recusa da habilitação em licitações públicas.

Antes, porém, a Lei nº 9.029/95 já havia proibido empresas que incorressem em crimes de preconceito de etnia, raça ou cor da obtenção de empréstimo ou financiamento junto a instituições financeiras oficiais (art. $3^{\circ}$, inciso II), impondo o respeito aos direitos humanos e à função social como condição da prosperidade econômica.

Outro ponto que merece destaque é a importância das perícias judiciais em ações em que se discute o nexo causal entre o trabalho e a doença. Os trabalhadores ainda são reféns de peritos despreparados e da escassez desses profissionais a serviço da Justiça do Trabalho. São raros os casos em que o magistrado, não convencido pelo laudo pericial inconclusivo ou inconsistente, revogam a habilitação e nomeiam um outro profissional. E são mais raros ainda os peritos que se dispõem a olhar além do nexo etiológico, lançando luzes para a complexidade do meio ambiente do trabalho e para a inter-relação pessoa-ambiente, considerando também os impactos da organização e das condições de trabalho na saúde do 
trabalhador, tanto para o desencadeamento como para o agravamento de doenças, preexistentes ou não.

À título de ilustração, bastou que o Tribunal Superior do Trabalho reconhecesse a penosidade da atividade de telemarketing para que magistrados e peritos se atentassem para o que a literatura científica há tempos denunciava: a rigidez da organização do trabalho e a precarização das condições laborais do setor. Por isso, é importante compreender que não basta apenas examinar o trabalhador adoecido, mas também considerar os fatores e aspectos (pessoais e ambientais) do meio ambiente do trabalho no qual ele se encontrava imerso.

Quanto à função administrativa, que compete ao Poder Executivo, extrai-se do art. $6^{\circ}$, parágrafo $3^{\circ}$, da Lei $n^{\circ} 8.080 / 90$, o dever do Poder Público, por meio do SUS, prestar assistência ao trabalhador vítima de doença ocupacional ou acidente de trabalho; participar na normatização, fiscalização e controle de produtos, equipamentos e máquinas; participar de estudos, pesquisas, avaliação e controle de riscos à saúde do trabalhador; informar trabalhadores, sindicatos e empregadores sobre os riscos do trabalho e do local de trabalho; avaliar o impacto das tecnologias na saúde; atualizar e revisar periodicamente a listagem oficial de doenças ocupacionais; e garantir ao sindicato dos trabalhadores o pleito ao órgão competente da interdição de máquina, de setor de serviço ou de todo o ambiente de trabalho, quando houver exposição a risco iminente para a vida ou saúde dos trabalhadores.

Portanto, atentará o Estado contra o direito ao meio ambiente do trabalho equilibrado, à saúde e à dignidade do trabalhador quando descumprir qualquer das prestações arroladas no art. $6^{\circ}$, parágrafo $3^{\circ}$, da Lei $n^{\circ} 8.080 / 90$.

A orientação e fiscalização do cumprimento das normas trabalhistas e de saúde e segurança no trabalho, dever do Estado e não apenas dos sindicatos, ainda são ineficazes. Concordamos com a doutrina brasileira quando aponta que a inspeção do trabalho pelas Delegacias Regionais do Trabalho, como órgão do Ministério do Trabalho, não tem sido eficiente na proteção da saúde do trabalhador ${ }^{382}$. José Antonio Ribeiro de Oliveira Silva considera a Convenção no 81 da OIT, aprovada em 1947, na 30ª Reunião da Conferência Internacional do Trabalho, um importante marco normativa a respeito da inspeção no trabalho, a qual previu em seu art. $3^{\circ}$ três atribuições ao sistema de inspeção de trabalho: assegurar a aplicação das disposições legais às condições de trabalho e à proteção dos

${ }^{382}$ SILVA, José Antônio Ribeiro de Oliveira. A saúde do trabalhador como um direito humano: conteúdo essencial da dignidade humana. São Paulo: LTr, 2008. 
trabalhadores no exercício de sua atividade (referentes, por exemplo, à duração do trabalho, salário, segurança, higiene, bem-estar, etc.); orientar empregadores e trabalhadores sobre os meios mais eficazes de efetivar as normas; dar ciência à autoridade competente sobre deficiências ou abusos não especificamente previstos nos dispositivos legais. Ratificada pelo Brasil 25 de abril de 1957, essa Convenção foi denunciada em 1971 e restabelecida dezesseis anos mais tarde, por meio do Decreto nº 68.796/1987.

A fiscalização, ou inspeção, pelos auditores fiscais é de suma relevância para a defesa do meio ambiente do trabalho e compreende duas atribuições, orientação e autuação para imposição de multas, nos termos dos artigos 626, 627 e 627-A da Consolidação das Leis do Trabalho. No entanto, conforme relatou o sindicato participante deste estudo, a fiscalização ainda é precária, tanto o Ministério do Trabalho e Emprego, através de suas Delegacias Regionais de Trabalho que contam com poucos auditores para atender à expressiva demanda, como pelo sindicato, que pelo mesmo motivo acompanha de forma mais incisiva apenas empresas com mais de cinquenta empregados. Em consulta direta ao Ministério do Trabalho e Emprego, soube-se que atualmente tem-se apenas 2.900 auditores fiscais para atender a demanda de todo o país, enquanto, seriam necessários 8.000, de acordo com a Organização Internacional do Trabalho.

Por isso, segundo Raimundo Simão de Melo, o insucesso da atuação fiscalizatória do Ministério do Trabalho e Emprego deve ser creditado a três fatores: à escassez de estruturas humana e material adequadas, à falta de política preventiva definida e às ínfimas multas administrativas previstas da Consolidação das Leis do Trabalho (art. 201), que estimulam os empregadores a correr o risco da autuação ${ }^{383}$.

O Ministério Público do Trabalho, um dos braços do Ministério Público da União, possui autonomia funcional e administrativa, como órgão independente dos poderes legislativo, executivo e judiciário, na proteção dos direitos fundamentais e na defesa do meio ambiente do trabalho. Resta, portanto, que se aproprie da sua função institucional, conforme destaca Sueli Gandolfi Dallari, de zelar pelos serviços de relevância pública, dentre os quais se inclui as ações de serviços e medidas de saúde no campo do trabalho, buscando a

\footnotetext{
${ }^{383}$ MELO, Raimundo Simão de. Direito ambiental do trabalho e a saúde do trabalhador: responsabilidades legais, dano material, dano moral, dano estético, indenização pela perda de uma chance, prescrição. 4. ed. São Paulo: LTr, 2010.
} 
efetivação das prestações as quais se obrigam empregadores e o Estado, principalmente em caso de omissão ${ }^{384}$.

Entrementes, é também papel do Estado promover a educação geral da população, desde as salas de aula até os ambientes de trabalho, no tocante à saúde e segurança no trabalho, cuja matéria até hoje não foi incluída nos projetos pedagógicos dos cursos de Direito. Não se efetivou a diretriz prevista no art. 225, inciso VI, da Constituição Federal, cujo mandamento consiste na promoção da educação ambiental em todos os níveis de ensino e a conscientização de todos à preservação do meio ambiente, nele incluído o do trabalho.

É a informação e a educação que garantem ao trabalhador a condição de cidadão consciente e esclarecido para cobrar do Poder Público a efetivação dos direitos à saúde, ao trabalho, à dignidade e ao meio ambiente do trabalho equilibrado, entre outros direitos fundamentais. Cobranças tanto externas, direcionadas ao Poder Público, como internas, direcionadas aos empregadores.

${ }^{384}$ DALLARI, Sueli Gandolfi; et al. O conceito constitucional de relevância pública. Brasília: Organização Panamericana da Saúde, 1992. 


\section{CONCLUSÃO}

Nas últimas décadas do século XX, a internacionalização da economia e a sofisticação tecnológica decorrente da contemporânea Revolução das Tecnologias da Informação e Comunicação não apenas trouxeram novas perspectivas para a atividade econômica, sobretudo pela supressão de fronteiras e pela reinvenção do processo produtivo, mas também desencadearam um complexo processo de modificações técnicas e organizacionais que jamais poderiam ser desprezadas pelo Direito do Trabalho. Se por um lado a sofisticação tecnológica favoreceu ao aumento da produtividade e ao atendimento da demanda consumerista, por outro, intensificou o ritmo do trabalho, tornando-o mais compacto e controlado.

A diversidade de estudos nas mais variadas áreas do conhecimento tem demonstrado os impactos dos processos de modernização técnica e organizacional na saúde do trabalhador e a sobreposição dos direitos do consumidor aos do trabalhador em diversas situações, em detrimento da fundamentalidade dos direitos ao trabalho, à vida, à saúde e à dignidade.

Como objetivo nuclear deste estudo, buscou-se analisar a complexidade do meio ambiente do trabalho através da sistematização dos fatores e aspectos que o compõem e a influência da estrutura socioeconômica consumerista no seu equilíbrio e na saúde do trabalhador.

A tese aqui defendida é a de que os aspetos constituintes do meio ambiente do trabalho, sejam eles físicos (ambientais - geográficos, arquiteturais-tecnológicos, organizacionais e socioculturais) ou não físicos (pessoais - comportamentais e psicológicos), são inter-relacionados e produzem tanto mudanças quanto continuidade nas características do trabalhador, influenciando, inclusive, no seu estado de saúde. Não bastasse essa malha de influências, o meio ambiente do trabalho também interage com outros contextos e sistemas ambientais (econômico, social, jurídico, político e cultural), nos quais se encontra imerso e a eles é inseparavelmente relacionado. 
Com base nos referenciais teóricos do Direito Labor-ambiental e da Psicologia Ambiental, foram propostos dois novos princípios: o Princípio da Bidirecionalidade e o Princípio da Interdependência. Por entendermos que esses dois postulados sugeridos são verdades fundantes, máximas da relação entre o ser humano e o seu entorno, adotamos a forma de princípio e não a de pressuposto; porque além deles servirem para a análise de uma situação concreta (perícias, intervenções ambientais, etc.), entendemos também que eles são essenciais na elaboração e na interpretação das normas de saúde e segurança no trabalho, ou até mesmo para suprir eventual lacuna.

O Princípio da Bidirecionalidade pessoa-ambiente preleciona que a pessoa é parte integrante e inseparável do ambiente e não apenas nele se encontra. Pessoa e ambiente se relacionam e se influenciam, recíproca e continuamente. Portanto, o trabalhador influi no meio ambiente do trabalho e este na maneira como ele percebe, experimenta, vivencia e interage com o contexto laboral.

Por sua vez, o Princípio da Interdependência assevera a existência de uma interação entre as diversas manifestações ambientais (natural, artificial, cultural e do trabalho) e dos fatores inerentes a cada uma delas (sociais, econômicos, políticos, jurídicos, etc.), que dialogam entre si e influenciam tanto no equilíbrio do meio ambiente do trabalho como na maneira em que o trabalhador enxerga, experimenta, negocia e dialoga com o meio em que ele se encontra imerso. Significa dizer que o trabalhador é influenciado tanto por aspectos de outras dimensões ou contextos ambientais, nas quais ele também se encontra ou não, como por elementos macrossistêmicos, mediatos e mais distais (sociais, econômicos, políticos, jurídicos, etc.), que embora não sejam atributos imediatos do meio ambiente do trabalho, influenciam no seu equilíbrio, pois refletem na organização da atividade e nas políticas públicas que afetam a seara trabalhista.

É o caso dos impactos do consumo no meio ambiente do trabalho e na saúde do trabalhador.

A relação entre consumo e trabalho não se estreita apenas na semelhança entre institutos do Direito do Trabalho e do Direito do Consumidor e no caráter social e protetivo desses ramos jurídicos. Essas searas são essencialmente interdependentes, mormente porque tanto o trabalho como o consumo são elementos inerentes ao sistema produtivo. Por isso são influenciados pelo macrossistema, constituído pelos sistemas econômico, social, jurídico, 
político e cultural, que estabelecem padrões para estruturas e atividades que ocorrem no plano concreto.

A tensão entre interesses econômicos e sociais também se impõe tanto na relação de consumo como na relação de trabalho, havendo ainda uma interdependência desses interesses tanto dentro de cada uma dessas relações como entre uma e outra. Se para o crescimento econômico o investimento é fundamental, para o desenvolvimento social há que se viabilizar não apenas o acesso aos bens materiais, mas também aos serviços de saúde e ao trabalho, pois são eles que garantem o retorno do investimento econômico. A melhoria das condições de vida, nela incluídas as condições de trabalho, não está necessariamente na esfera do mercado de consumo. Por isso, não há que se falar em consumo como um dos principais elementos do desenvolvimento social, sobrepondo-o ao trabalho. Este sim, desde que em condições dignas e adequadas, importa em cidadania, dignidade, desenvolvimento, melhoria das condições de vida, justiça social e, inclusive, possibilita o acesso aos bens de consumo.

O conflito entre interesses econômicos (assentados no modelo capitalista empresarial e da política de harmonização da relação de consumo) e interesses sociais (como a proteção ao meio ambiente do trabalho e a defesa da saúde do trabalhador), tem contribuído para a precarização das condições laborais, sobretudo por influenciarem na organização e no equilíbrio do meio ambiente do trabalho. A instituição de políticas de harmonização da relação de consumo sem qualquer coordenação com o estabelecimento e manutenção das garantias sociais, tornou-se mais um trunfo do capital na velha quizila com o trabalho.

Para ilustrar os impactos do consumo no meio ambiente do trabalho e na saúde do trabalhador, analisamos tal fenômeno no contexto da atividade de telemarketing. Como um dos mecanismos alternativos de solução de conflitos de consumo previstos no art. $4^{\circ}$, inciso V, do Código de Defesa do Consumidor, o telemarketing é talvez o instrumento de harmonização da relação consumerista que esteja mais a serviço do consumidor. Não se duvida ser por esse motivo que a atividade expandiu-se surpreendentemente nos últimos anos e gerou milhares de empregos no país, despertando a atenção de consumidores, empresários, trabalhadores, sindicatos e até mesmo do Estado.

$\mathrm{O}$ aspecto organizacional dessa atividade é um dos fatores que contribuem para o tensionamento dos interesses de trabalhadores e consumidores. Isso porque a organização da atividade de telemarketing é pautada, essencialmente, no elemento "tempo". Controla-se a 
duração da chamada, da transferência de ligações e até mesmo o afastamento do teleoperador do posto de atendimento, para que não haja abandono de chamadas ou elevado tempo de espera dos clientes consumidores para serem atendidos. O fator tempo também é um dos critérios para a contratação dos serviços das empresas de telemarketing, cujo ajuste deve estipular o período e o número de posições dedicadas ao tomador. Portanto, se os teleoperadores são destinatários do direito ao trabalho e ao meio ambiente do trabalho equilibrado, os consumidores são destinatários do direito a um atendimento de qualidade, que compreende tanto a celeridade como a efetividade da prestação do serviço.

O telemarketing, que se consagrou no Brasil no final de década de 90 como um importante mecanismo da Política Nacional de Harmonização da Relação de Consumo, tornou-se, sem demora, arena de infindáveis lides trabalhistas nos últimos tempos, impulsionando diversos estudos científicos das mais diversas áreas do conhecimento, em razão do alto índice de teleoperadores adoecidos. É por isso que, em 24 de maio de 2011, o Pleno do Tribunal Superior do Trabalho reconheceu e penosidade dessa atividade e cancelou a Orientação Jurisprudencial no 273 da Seção Especializada de Dissídios Individuais 1, que vedava a aplicação por analogia aos teleoperadores da jornada reduzida de que trata o artigo 227 da Consolidação das Leis do Trabalho, fixando em seis horas a jornada de trabalho para essa categoria profissional.

Em resposta à denunciada precarização dos atendimentos e das condições de trabalho no setor de telemarketing, entre 2007 e 2008 passaram a viger dois dispositivos normativos: o Decreto $\mathrm{n}^{\mathrm{o}}$ 6.523, de 31 de julho de 2008 - que fixou normas gerais sobre o Serviço de Atendimento ao Consumidor (SAC) - e o Anexo II da NR 17, instituído pela Portaria $n^{\circ}$ 9/2007 do Ministério do Trabalho e Emprego. Colidentes entre si, esses dois dispositivos exerceram incontestável impacto no meio ambiente do trabalho, sobretudo na organização e nas condições laborais, em razão da necessidade de reestruturação do processo produtivo inerente a essas normas.

Enquanto o Decreto $\mathrm{n}^{\circ}$ 6.523/08 impôs tempo máximo para a duração da transferência de ligações e de solução para as reclamações, acelerando o ritmo de trabalho sem prejuízo do dever de objetividade e clareza das informações, o Anexo II da NR 17 garantiu o aumento de pausas fora do posto de trabalho, a proibição de aceleração do trabalho e vetou a adoção de mecanismos de monitoramento da produtividade. Significa dizer que o Decreto $\mathrm{n}^{\circ}$ 6.523/08, aprovado cerca de um ano após o Anexo II da NR 17, privilegiou os 
consumidores em detrimento das precárias condições de trabalho suportadas pelos teleoperadores e reconhecidas no referido Anexo.

No entanto, consideramos que o Anexo II da NR 17 cumpriu sua função harmonizadora ao equacionar interesses econômicos e sociais, prevendo em seus itens 5.2 e 5.2.1 o dever das empresas do setor equacionar o contingente de teleoperadores em cada estabelecimento à demanda, para garantir que todos pudessem usufruir das pausas e dos intervalos previstos, evitando sobrecarga de trabalho e a precarização da qualidade da prestação do serviço aos consumidores. Já o Decreto $n^{\circ}$ 6.523/08, posterior ao referido Anexo, sequer mencionou a necessidade desse equacionamento ou sugeriu qualquer proporcionalidade entre posições de atendimento e demanda. Cobrou-se mais qualidade de atendimento e menos observância dos parâmetros mínimos de segurança e conforto para o desempenho da atividade.

Entendemos que, em tese, essa antinomia é apenas aparente, pois o Anexo II da NR 17 previu o dever dos empregadores equacionarem o contingente de teleoperadores em cada estabelecimento à demanda. Porém, na prática, essa previsão já existia antes mesmo da aprovação do Decreto $n^{\circ}$ 6.523/08 e não se viu qualquer medida política ou fiscalizatória que buscasse efetivar esse equacionamento, conforme destacou o Sindicato entrevistado.

Ademais, diante de um conflito entre o Decreto $n^{\circ}$ 6.523/08 do Ministério da Justiça e a Portaria no 9/2007 do Ministério do Trabalho e Emprego, subsiste a última por ser mais favorável ao trabalhador. É deve do empregador garantir um meio ambiente do trabalho equilibrado e promover a defesa da saúde do trabalhador, buscando eliminar ou reduzir os riscos da atividade, nos termos do mandamento constitucional insculpido no art. $7^{\circ}$, inciso XXII. Além disso, o direito ao trabalho, à dignidade e à saúde, espécies de direitos humanos, garantem a prevalência do Anexo II da NR 17, instituído pela Portaria no 9/2007 do Ministério do Trabalho e Emprego. Essa norma regulamentadora nada mais é do que um instrumento de efetivação desses direitos fundamentais que prevalecem a qualquer outro direito, inclusive ao do consumidor a um atendimento célere e adequado.

Os dados apresentados neste estudo evidenciaram que: (a) em todos os anos compreendidos entre o período de 2006 a 2011, a quantidade de acidentes do trabalho no setor de telemarketing, sem emissão de CAT, corresponde, em média, a 1/3 da totalidade anual de acidentes (Figura 7); (b) entre 2007 e 2009, mesmo após a vigência do Anexo II da NR 17, 
houve aumento da quantidade de acidentes do trabalho (Figura 8); (c) 80\% dos consumidores estão insatisfeitos com os serviços de telemarketing (Figura 4); (d) 26\% dos consumidores apontaram insatisfação em relação ao serviço de atendimento ao consumidor prestado pelas empresas de telefonia (Figura 5); 51,2\% das justificativas da insatisfação dos consumidores em relação ao serviço de telemarketing diz respeito à qualidade do atendimento (demora ou ineficiência - Figura 6).

A insatisfação dos consumidores em relação aos serviços de telemarketing demonstra a ineficácia das novas regras para o serviço de atendimento ao consumidor, instituídas pelo Decreto $\mathrm{n}^{\circ}$ 6.523/08 do Ministério da Justiça. A precária fiscalização e a concepção unilateral desse dispositivo, sem a participação das empresas de telemarketing e do sindicato da categoria econômica, são alguns dos possíveis motivos desse insucesso regularmente denunciado nas mídias sociais e nos meios de comunicação nos últimos tempos.

E não se duvida que essa insatisfação tem impactado no trabalho em telemarketing, contribuindo para a precarização das condições laborais do setor. A queixa dos consumidores quanto ao elevado tempo de espera é um indício de que as empresas de telemarketing não adequaram o contingente de teleoperadores à demanda e da sobrecarga de trabalho no setor, tendente à intensificação do ritmo de trabalho.

Portanto, não houve benefício para nenhum dos protagonistas desse contexto, conforme evidenciou um dos participantes deste estudo.

Evidentemente, o ideal seria que a legislação cumprisse sua função sistematizadora, imprimindo unidade e coerência ao sistema jurídico, de modo a harmonizar os interesses dos trabalhadores e consumidores. Caso contrário, corre-se o risco de que os interesses econômicos se sobreponham aos direitos fundamentais garantidos a todo cidadão, como o direito à dignidade, à saúde, à informação e ao meio ambiente equilibrado, nele incluído o do trabalho.

Consoante ao que determina a Política Nacional das Relações de Consumo, o mandamento principiológico contido no art. $4^{\circ}$, inciso III, do Código de Defesa do Consumidor, é harmonizar, equacionar, equilibrar as relações de consumo. É garantir o respeito à dignidade, saúde, segurança, qualidade de vida e a proteção dos interesses econômicos dos consumidores, sem que isso inviabilize o desenvolvimento econômico e tecnológico. É, em suma, a ideia de equilíbrio e não de sobreposição. 
Como os "lírios não nascem da lei"385, cabe a todos os atores sociais envergarem esforços para que os direitos sociais não sejam sufocados pelos interesses econômicos; para que os direitos fundamentais ao meio ambiente do trabalho equilibrado, à saúde, à dignidade e ao trabalho sejam efetivados e não tratados como empecilhos para o desenvolvimento econômico; e para que o Anexo II da NR 17, bem como tantos outros dispositivos atinentes à matéria saúde e segurança no trabalho, sejam observados como instrumentos de redução dos riscos inerentes à atividade e ao locus laboral, sem prejuízo de outras medidas que busquem neutralizá-los, nos termos do mandamento constitucional cristalizado no art. $7^{\circ}$, inciso XXII.

385 DRUMMOND DE ANDRADE, Carlos. Nosso tempo. In: Record, 2000. p. 29-37. A rosa do povo. 21. ed. Rio de Janeiro: 


\section{REFERÊNCIAS}

ALMEIDA, Carlos Ferreira de. Os direitos do consumidor. Coimbra: Almedina, 1982. 360 p.

ALMEIDA, Victor Hugo de. Sala de descanso em empresas de telemarketing e qualidade de vida. 2008. 143 f. Dissertação (Mestrado em Psicologia) - Faculdade de Filosofia, Ciências e Letras de Ribeirão Preto, Universidade de São Paulo, São Paulo, 2008.

ANTONELLI, Valdir. Faturamento do setor crescerá para R\$ 23 bi em 2010. Portal Call Center, São Paulo, set. 2010. Disponível em: $<$ http://portalcallcenter.consumidormoderno.uol.com.br/indicadores/anuario/faturamento-dosetor-crescera-para-r-23-bi-em-2010>. Acesso em: 29 set. 2011.

ANTUNES, Paulo Bessa. Direito Ambiental. 7. ed. 2. tir. Rio de Janeiro: Lumen Juris, 2005. $239 \mathrm{p}$.

ANTUNES, Ricardo. Os sentidos do trabalho: ensaio sobre a afirmação e a negação do trabalho. São Paulo: Boitempo Editorial, 1999. 258 p.

ASENSI, Felipe Dutra. Biodireito, saúde e participação social. In: Âmbito Jurídico, Rio Grande, IX, n. 32, ago 2006. Disponível em: <http://www.ambito-juridico.com.br/site/? $\mathrm{n} \_l i n k=$ revista_artigos_leitura\&artigo_id $=1232 \&$ revista_caderno=6 $>$. Acesso em: 12 ago. 2012.

ASSOCIAÇÃO BRASILEIRA DE TELESSERVIÇOS. O que é Telemarketing? São Paulo, 2005. Disponível em: <http://www.abt.org.br/telemarketing.asp>. Acesso em: 12 set. 2012.

. Pesquisa da PUC-SP radiografa o call center brasileiro. São Paulo, 2006. Disponível em: <http://www.abt.org.br/pesquisa.asp?banner=ABT>. Acesso em: 16 maio 2011.

AWAD, George; VORUGANTI, Lakshmy Narayana Pant. Intervention research in psychosis: issues related to the assessment of quality of life. Schizophrenia Bulletin. Disponível em: <http://schizophreniabulletin.oxfordjournals.org/content/26/3/557.full.pdf + html>. Acesso em: 8 jun. 2011.

BARDIN, Laurence. Análise de conteúdo. Tradução Luís Antero Reto e Augusto Pinheiro. Lisboa: Edições 70, 1977. 223 p.

BELO, Maria Nerita de L. S. A importância da fisioterapia preventiva para os operadores de telemarketing. 2008. $71 \mathrm{f}$. Monografia - Universidade Veiga de Almeida, Rio de Janeiro, 2008. Disponível em: <http://www.uva.br/cursos/graduacao/ccbs/fisioterapia_monografias/ importancia_da_fisioterapia_preventiva_para_os_operadores_de_telemarketing.pdf $>$. Acesso em: 23 maio 2011. 
BELTRAN, Ari Possidonio. Os impactos da integração econômica no direito do trabalho: globalização e direitos sociais. São Paulo: LTr, 1998. 405 p.

BLASS, Leila Maria da Silva. Trabalho bancário: O (re)fazer de todo instante. Cadernos de Formação Sindical, São Paulo, n. 2, p. 20, 1989.

BOBBIO, Norberto. A era dos direitos. 10. reimp. Rio de Janeiro: Elsevier, 2004. 212 p.

Teoria do Ordenamento Jurídico. Tradução Maria Celeste C. J. Santos 10. ed. Brasília: Editora Universidade de Brasília, 1999. 184 p.

BONATTO, Cláudio. Questões controvertidas no Código de Defesa do Consumidor: principiologia, conceitos, contratos. 4. ed. Porto Alegre: Livraria do Advogado, 2003. 239 p.

BONI, Valdete; QUARESMA, Sílvia Jurema. Aprendendo a entrevistar: como fazer entrevistas em Ciências Sociais. Revista Eletrônica dos Pós-Graduandos em Sociologia Política da UFSC, Santa Catarina, v. 2, n. 1(3), p. 68-80, 2005.

BOUCINHAS FILHO, Jorge Cavalcanti. Tutela judicial e movimentos grevistas: um estudo sobre a atuação dos órgãos do poder judiciário diante das novas formas de manifestação coletiva dos operários. 2012. 276 f. Tese (Doutorado em Direito) - Faculdade de Direito, Universidade de São Paulo, São Paulo, 2012.

BRAGA, Ruy. Uma sociologia da condição proletária contemporânea. Tempo Social, Revista de Sociologia da USP, São Paulo, v. 18, n. 1, p. 133-152, 2006.

BRANDÃO, Cláudio Mascarenhas. Proteção jurídica à saúde do trabalhador: uma necessária (re)leitura constitucional. Revista LTr, São Paulo, v. 74, n. 1, p. 24-29, 2010.

BRAVERMAN, Harry. Trabalho e capital monopolista: a degradação do trabalho no século XX. Tradução Nathanael C. Caixeiro. 3. ed. Rio de Janeiro: Guanabara, 1987. 379 p.

BRONFENBRENNER, Urie. Toward an experimental ecology of human development. American Psychologist, Washington, v. 32, p. 513-531, 1977.

BULOS, Jaime Leandro; GERAIGE NETO, Zaiden. Breves considerações sobre a possibilidade de condenação por dano moral coletivo às instituições bancárias, quando prejudicado o cliente-consumidor: aspectos materiais e processuais. In: RIBEIRO, José Horácio Halfeld Rezende. (Coord.). Revista de Direito Bancário e do Mercado de Capitais, a. 15, n. 57 , p. 13-27. jul/set. 2012.

CAMELO, Silvia Helena Henriques, et al. Adoecimento e promoção da saúde do trabalhador. In: VIII Seminário de Saúde do trabalhador e VI Seminário O trabalho em debate, 2012, Franca. Anais do VIII Seminário de Saúde do trabalhador e VI Seminário O Trabalho em debate, 2012.

CAMPOS-DE-CARVALHO, Mara. A metodologia do experimento ecológico. In: PINHEIRO, José Q.; GÜNTHER, Hartmut. (Orgs.). Métodos de pesquisa nos estudos pessoa-ambiente. São Paulo: Casa do Psicólogo, 2008. p. 11-52. 
Pesquisas contextuais e seus desafios: uma contribuição a partir de investigação sobre arranjos espaciais em creches. Estudos de Psicologia, Natal, v. 8, n. 2, p. 289-297, maio/ago. 2003.

Psicologia ambiental - Algumas considerações. Psicologia: Teoria e Pesquisa, Brasília, v. 9, n. 2, p. 435-447, 1993.

; CAVAlCANTE, Sylvia; NÓBREGA, Lana Mara Andrade. Ambiente. In: CAVAlCANTE, Sylvia; ElAli, Gleice A. (Orgs). Temas básicos de Psicologia Ambiental. Petrópolis: Vozes, 2011. p. 28-43.

CARAZZAI, Estelita Hass. TIM derruba sinal de propósito, diz ANATEL. Folha de São Paulo, São Paulo, 7 ago. 2012. Disponível em: <http://www1.folha.uol.com.br/mercado/ 1132964-tim-derruba-sinal-de-proposito-diz-anatel.shtml>. Acesso em: 7 ago. 2012.

CASSAR, Vólia Bomfim. Direito do Trabalho. 5. ed. Niterói: Impetus, 2011. 1411 p.

CASTELLS, Manuel. A Era da Informação: economia, sociedade e cultura. Fim de milênio. v. 3. Tradução Klauss Brandini Gerhardt e Roneide Venancio Majerv. São Paulo: Paz e terra, 1999. $617 \mathrm{p}$.

CAUDAS, Aulete. Aulete Digital. Dicionário Contemporâneo da Língua Portuguesa. São Paulo: Lexicon, 2008. Disponível em: <http://aulete.uol.com.br/site.php?mdl=aulete_digital〉. Acesso em: 30 ago. 2012.

COMPARATO, Fábio Konder. Função social da propriedade dos bens de produção. Revista de Direito Mercantil, São Paulo, n. 63, p. 63-73, 1990.

CORDEIRO, Hésio. Sistema Único de Saúde. Rio de Janeiro: Ayuri Editorial, 1991. 184 p.

COSTA, Judith Martins. A 'Guerra' do Vestibular e a Distinção entre Publicidade Enganosa e Clandestina. Revista Direito do Consumidor, São Paulo, v. 6, p. 219-231, abr./jun. 1993.

CUNHA, Antônio Geraldo da. Dicionário etimológico Nova Fronteira da Língua Portuguesa. Rio de Janeiro: Nova Fronteira, 1997. 101 p.

CURREA-LUGO, Víctor de. La salud como derecho humano: 15 requisitos y uma mirada a lãs reformas. Bilbao: Cuadernos Deusto de Derechos Humanos, Universidade de Deusto, 2005. 127 p.

DALLARI, Dalmo de Abreu. A Constituição na vida dos povos: da Idade Média ao século XXI. São Paulo: Saraiva, 2010. 360 p.

DALLARI, Sueli Gandolfi. Comunicação - Centro de Estudos e Pesquisas de Direito Sanitário. Supremo Tribunal Federal, Brasília, 6 maio 2009. Disponível em: <http://www.stf.jus.br/arquivo/cms/processoAudienciaPublicaSaude/anexo/SUELI_DALLAR I.pdf $>$. Acesso em: 8 out. 2012.

DALLEGRAVE NETO, José Affonso. A força vinculante das Normas Regulamentadoras do Ministério do Trabalho e Emprego (NRs do MTE) e o Anexo II da NR-17. Revista do Tribunal Regional do Trabalho da $1^{a}$ Região, Rio de Janeiro, v. 21, n. 48, p. 119-123, jul./dez. 2010. 
DANTAS, Edmundo Brandão. Telemarketing: a chamada para o futuro. São Paulo: Atlas, 2000. $438 \mathrm{p}$.

DE LUCCA, Newton. Teoria geral da relação jurídica de consumo. 2001. 117 f. Tese (Titular) - Faculdade de Direito, Universidade de São Paulo, São Paulo, 2001.

DEJOURS, Cristophe. A loucura do trabalho: estudo de psicopatologia do trabalho. São Paulo: Oboré Editorial, 1987. 163 p.

DELGADO, Maurício Godinho. Curso de Direito do Trabalho. 8. ed. São Paulo: LTr, 2009. $1344 \mathrm{p}$.

DIAS, Elizabeth Costa. Aspectos atuais da saúde do trabalhador no Brasil. In: ROCHA, Lys Esther; BUSCHINELLI, Tarcísio José; RIGOTTO, Raquel Maria. (Orgs.). Isto é trabalho de gente? Vida, doença e trabalho no Brasil. Petrópolis: Vozes, 1993. p. 138-156.

DRUMMOND DE ANDRADE, Carlos. Nosso tempo. In: A rosa do povo. 21. ed. Rio de Janeiro: Record, 2000. p. 29-37.

ECO, Humberto. Como se faz uma tese. Tradução Gilson Cesar Cardoso de Souza. 23. ed. São Paulo: Perspectiva, 2010. 174 p.

ELALI, Gleice Azambuja. Psicologia e arquitetura: em busca do locus interdisciplinar. Estudos de Psicologia, Natal, v. 2, n. 2, p. 349-362, 1997.

FELICIANO, Guilherme Guimarães. Meio ambiente do trabalho: aspectos gerais e propedêuticos. Síntese Trabalhista, Porto Alegre, v. 14, n. 162, p. 122-153, dez. 2002.

Tópicos avançados de direito material do trabalho: atualidades forenses. v. 1. São Paulo: Editora Damásio de Jesus, 2006. 194 p.

FERNANDES, Fábio. Meio ambiente geral e meio ambiente do trabalho: uma visão sistêmica. São Paulo: LTr, 2009. 285 p.

FERREIRA, Aurélio Buarque de Hollanda. Dicionário da Língua Portuguesa. 11. ed. Rio de Janeiro: Editora Civilização Brasileira, 1987. 1838 p.

FERREIRA, Gisele Rodrigues. Direito ambiental do trabalho. Boletim Jurídico, Uberaba, v. 3, n. 117, 2005. Disponível em: <http://www.boletimjuridico.com.br/doutrina/ texto.asp?id=542>. Acesso em: 24 jan. 2011.

FERREIRA, Marcos Ribeiro. Problemas ambientais como desafio para a psicologia. In GÜNTHER, Hartmut; PINHEIRO, José Q.; GUZZO, Raquel Souza Lobo. (Orgs.). Psicologia Ambiental: entendendo as relações do homem com seu ambiente. Campinas: Alínea, 2004. p. 17-30.

FIGUEIREDO, Guilherme José Purvin de. Direito ambiental e a saúde dos trabalhadores. 2. ed. São Paulo: LTr, 2007. 254 p. 
FILOMENO, José Geraldo Brito. Da política nacional das relações de consumo. In BENJAMIM, Antonio Herman V. et al. Código brasileiro de defesa do consumidor: comentado pelos autores do anteprojeto. Rio de Janeiro: Forense Universitária, 1998, p. 43105 .

Manual de direitos do consumidor. 10. ed. São Paulo: Atlas, 2010. 861 p.

FIORILLO, Celso Antonio Pacheco. Curso de direito ambiental brasileiro. 8. ed. ver. atual. e ampl. São Paulo: Saraiva, 2007. 554 p.

; RODRIGUES, Marcelo Abelha. Direito Ambiental e Patrimônio Genético. Belo Horizonte: Editora Del Rey, 1996. 285 p.

FOLHA DE SÃO PAULO. Editorial, 13 jun. 2010. Disponível em: <http://www1.folha.uol.com.br/fsp/opiniao/fz1306201002.htm>. Acesso em: 12 set. 2012.

Funcionário da Vivo orienta cliente a jogar celular na parede. São Paulo, 16 out. 2012. Disponível em: <http://www1.folha.uol.com.br/mercado/1169719-funcionario-da-vivoorienta-cliente-a-jogar-celular-na-parede.shtml>. Acesso em: 16 out. 2012.

Loja que mandou cliente "procurar macho" fez mais ofensas, diz outra consumidora,

São Paulo, Caderno Mercado, 12 set. 2012. Disponível em: $<$ http://www1.folha.uol.com.br/mercado/1152223-loja-que-mandou-cliente-procurar-machofez-mais-ofensas-diz-outra-consumidora.shtml>. Acesso em: 12 set. 2012.

FOLHA ONLINE. Telemarketing gera 500 mil empregos no Brasil, 60\% em SP. São Paulo, 26 dez. 2003. Disponível em: <http://www1.folha.uol.com.br/folha/dinheiro/ult91u 78596.shtml>. Acesso em: 10 maio 2011.

FONSECA, Maria Hemília. Curso de metodologia na elaboração de trabalhos acadêmicos. Rio de Janeiro: Editora Ciência Moderna, 2009. 106 p.

Direito ao trabalho: um direito fundamental no ordenamento jurídico brasileiro. São Paulo: LTr, 2009. 240 p.

FRAGA, Alexandre. Da rotina à flexibilidade: análise das características do fordismo fora da indústria. Revista Habitus: IFCS/UFRJ, Rio de Janeiro, v. 3, n. 1, p. 36-43, 2006.

FREITAS JR., Antonio Rodrigues de. Direito do trabalho na era do desemprego. São Paulo: LTr, 1999. 188 p.

GALASSO, Leonilde Ribeiro. Humor e estresse no trabalho: fatores psicossociais estressores e benéficos no trabalho dos operadores de Telemarketing. 2005. $260 \mathrm{f}$. Tese (Doutorado em Saúde Pública) - Faculdade de Saúde Pública, Universidade de São Paulo, São Paulo, 2005.

GARCIA, Leonardo de Medeiros. Direito do consumidor: código comentado, jurisprudência, doutrina. Decreto nº 2.181/1997. 8. ed. Niterói: Impetus, 2012. 
GODOY, Juan Francisco. Psicología de la salud: delimitación conceptual. In: SIMON, M. A. (Ed.). Manual de psicología de la salud. Fundamentos, metodología y aplicaciones. Madrid: Editorial biblioteca Nueva, 1999. p. 47-62.

GORENDER, Jacob. Globalização, tecnologia e relações de trabalho. Estudos Avançados, São Paulo, v. 11, n. 29, p. 311-361, 1997.

GRAVINA, Marcia Elena Rodrigues; ROCHA, Lys Esther Rocha. Lesões por Esforços Repetitivos em bancários: reflexões sobre o retorno ao trabalho. Cadernos de Psicologia Social do Trabalho, São Paulo, v. 9, n. 2, p. 41-55, 2006.

GUIBERT REYES, Wilfredo; GRAU ÁBALO, Jorge; PRENDES LABRADA, Mariela de la Caridad. ¿Cómo hacer más efectiva la educación en salud en la atención primaria? Revista Cubana Medicina General y Integral, Ciudad de La Habana, v. 15, n. 2, p. 176-183, 1999.

GÜNTHER, Hartmut. Como elaborar um questionário. In: PASQUALI, L. (Ed.). Instrumentos psicológicos: manual prático de elaboração. Brasília, DF: LabPAM; IBAPP, 1999. p. 231-257.

GUSTIN, Miracy Barbosa de Souza; DIAS, Maria Tereza Fonseca. (Re)pensando a Pesquisa Jurídica: teoria e prática. 2. ed. Belo Horizonte: Del Rey, 2006. 252 p.

HEALTH \& SAFETY EXECUTIVE. Advice regarding call centre working practices. 2006. Disponível em: <http://www.hse.gov.uk/lau/lacs/94-2.pdf>. Acesso em: 31 jun. 2012.

HIRIGOYEN, Marie-France. Mal-estar no trabalho: redefinindo o assédio moral. 5. ed. Rio de Janeiro: Bertrand Brasil, 2010. 352 p.

HOBSBAWM, Eric. A era dos extremos: o breve século XX. 2. ed. São Paulo: Companhia das Letras, 1997. 384 p.

HOUAISS. Antônio. Dicionário Houaiss da Língua Portuguesa. Rio de Janeiro: Objetiva, 2001. 2922 p.

JOHNSON, Neil. Os segredos do telemarketing. São Paulo: Littera Mundi, 2000. 136 p.

JUSTEN FILHO, Marçal. Curso de direito administrativo. 2. ed. São Paulo: Saraiva, 2006. $688 \mathrm{p}$.

LAKATOS, Eva Maria; MARCONI, Marina de Andrade. Fundamentos de metodologia científica. São Paulo: Atlas, 1985. 238 p.

LEAVELL, Hugh; CLARCK, Edwin Gurney. Medicina Preventiva. São Paulo: McGrawHill, 1976. 744 p.

LIMONGI-FRANÇA, Ana Cristina; RODRIGUES, Avelino Luiz. Stress e trabalho: uma abordagem psicossomática. 3. ed. São Paulo: Atlas, 2002. 181 p. 
MACHADO, Paulo Affonso Leme. Critérios para Diferenciação dos Princípios da Prevenção. Ecoambiental. Disponível em: 〈http://www.ecoambiental.com.br/principal/principios.html>. Acesso em: 8 jun. 2011.

Direito Ambiental Brasileiro. 13. ed. rev. atual. e ampl. São Paulo: Malheiros Editores, 2005. 1092 p.

MACHADO, Sidnei. O direito à proteção ao meio ambiente do trabalho no Brasil. São Paulo: LTr, 2001. 188 p.

MANCUSO, Rodolfo Camargo. Ação civil pública trabalhista: análise de alguns pontos controvertidos. Revista de Processo, RT, São Paulo, v. 93, a. 24, p. 12-37, 1996.

MANFREDI, Silvia Maria; BASTOS, Solange. 1998, Propostas e experiências de formação profissional no âmbito das organizações de trabalhadores. Cedes Unicamp, maio 1998. Disponível em: <http://www.cedes.unicamp.br/pesquisa/artigos/MANFREDI/indice.html>. Acesso em: 2 nov. 2011.

MANNRICH, Nelson. Terceirização: luzes e sombras. In: MARTINS, Sergio Pinto; MESSA, Ana Flávia (Coord.). Empresa e Trabalho. Estudos em homenagem a Amador Paes de Almeida. São Paulo: Saraiva, 2010. p. 181-202.

MARTINS, Sergio Pinto. Direito do Trabalho. 28. ed. São Paulo: Atlas, 2012. 920 p.

MARX, Karl. O capital: crítica da economia política. Tradução Regis Barbosa e Flávio R. Kothe. v.1, t. 1. São Paulo: Nova Cultural, 1996. 496 p.

MCCOY, Janetta Mitchell. Work environments. In: STOKOLS, Daniel; ALTMAN, Irwin (Eds.). Handbook of Environmental Psychology, New York: Wiley, 2002. v. 2, p. 443-460.

MELlO, Celso Antônio Bandeira de. Curso de Direito Administrativo. 29. ed. São Paulo: Malheiros, 2012. 1136 p.

MELO, Raimundo Simão de. Direito ambiental do trabalho e a saúde do trabalhador: responsabilidades legais, dano material, dano moral, dano estético, indenização pela perda de uma chance, prescrição. 4. ed. São Paulo: LTr, 2010. 559 p.

MELO, Rosane Gabriele C. de. Psicologia ambiental: uma nova abordagem da psicologia. Psicologia-USP, São Paulo, v. 2, n. 1/2, p. 85-103, 1991.

MIGUEL, Ricardo Georges Affonso. A inaplicabilidade de jornada reduzida e intervalos específicos ao operador de teleatendimento. Revista do Tribunal Regional do Trabalho da $1^{\text {a }}$ Região, Rio de Janeiro, v. 21, n. 48, p. 97-99, jul./dez. 2010.

MINISTÉRIO DA PREVIDÊNCIA SOCIAL. Anuário Estatístico da Previdência Social / Ministério da Previdência Social. Brasília: MPS/DATAPREV, 2006/2011. Disponível em: <http://www.previdencia.gov.br/conteudoDinamico.php?id=423>. Acesso em: 15 set. 2012.

MINISTÉRIO DA SAÚDE. Política Nacional de Saúde do(a) Trabalhador(a): Proposta para Consulta Pública. Brasília. In: Portal da Saúde, Brasília, 2004. Disponível em: 
<http://portal.saude.gov.br/portal/ arquivos/pdf/proposta_pnst_st_2009.pdf $>$. Acesso em: 12 set. 2012.

MOLZ, José Augusto. Telemarketing - aplicabilidade no Banco do Brasil SA. 2002. 57 f. Dissertação (Mestrado em Economia) - Programa de Pós-Graduação em Economia, Universidade Federal do Rio Grande do Sul, Porto Alegre, 2002.

MORAES, Paulo Valério Dal Pai. Código de defesa do consumidor: no contrato, na publicidade, nas demais práticas comerciais. 2. ed. Porto Alegre: Síntese, 2001. 327 p.

MORAIS, Mônica Maria Lauzid de. O direito à saúde e segurança no meio ambiente de trabalho. São Paulo: LTr, 2002. 190 p.

MOSER, Gabriel. Psicologia ambiental. Estudos de Psicologia, Natal, v. 3, n. 1, p. 121-130, jan./jun. 1998.

Psychologie environnementale: les relations homme-environnement. Bruelas: De Boeck, 2009. 298 p.

MOURA, Mauro Azevedo de. Novas tecnologias. Revista Brasileira de Saúde Ocupacional, São Paulo, v. 21, n. 79, p. 63-75, jul./set. 1993.

NASCIMENTO, Amauri Mascaro. A defesa processual do meio ambiente do trabalho. Revista Legislação do Trabalho, São Paulo, v. 63, n. 5, p. 583-587, maio 1999.

NASCIMENTO, Tupinambá Miguel Castro do. Curso de direito infortunístico. 3. ed. Porto Alegre: Fabris, 1992. 118 p.

NAVARRO, Vera Lúcia. Trabalho, subjetividade e lazer: estranhamento, fetichismo e reificação no capitalismo global. In: PADILHA, Valquiria. (Org). Dialética do Lazer. São Paulo: Cortez, 2006. p. 50-74.

NERY JUNIOR, Nelson. Princípios gerais do Código Brasileiro do Consumidor. Revista Direito do Consumidor, Editora RT, São Paulo, v. 3, set./dez. 1992.

NICOLACI-DA-COSTA, Ana Maria. Revoluções tecnológicas e transformações subjetivas. Psicologia: Teoria e Pesquisa, Brasília, v. 18, n. 2, p. 193-202, maio/ago. 2002.

NOGUEIRA, Claudia Mazzei. O trabalho duplicado: a divisão sexual no trabalho e na reprodução: um estudo das trabalhadoras do telemarketing. São Paulo: Expressão Popular, 2006. 240 p.

NUNES, Rizzato. Curso de Direito do Consumidor. 7. ed. São Paulo: Saraiva, 2012. 926 p.

ODA, Carla. Operadores de telemarketing: stress, autonomia, somatização e dores em pescoço e ombros. 2003. 138 f. Dissertação (Mestrado em Psicologia) - Instituto de Psicologia, Universidade de São Paulo, São Paulo, 2003.

OLIVEIRA, Elisângela Magela. Transformações no mundo do trabalho na Revolução Industrial aos nossos dias. Caminhos de Geografia, Uberlândia, v. 5, n. 11, p. 84-96, 2004. 
OLIVEIRA, Fernando César. Dieese: mesmo crescendo nos últimos dez anos, emprego no setor bancário é $70 \%$ do total há duas décadas. Agência Brasil - Empresa Brasil de Comunicação, 22 jul. 2012. Disponível em: <http://agenciabrasil.ebc.com.br/noticia/201207-22/dieese-mesmo-crescendo-nos-ultimos-dez-anos-emprego-no-setor-bancario-e-70-dototal-ha-duas-decadas>. Acesso em: 30 set. 2012.

OLIVEIRA, Maria Helena Barros de; VASCONCELLOS, Luiz Carlos Fadel. Direito e saúde - Possibilidades de um novo campo na luta pela Saúde do Trabalhador. $3^{a}$ Conferência Nacional de Saúde do Trabalhador, Brasília, maio 2005. Disponível em: <http://www.hc.ufmg.br/crest/downloads/Coletanea.pdf>. Acesso em: 28 jun. 2011.

OLIVEIRA, Paulo Eduardo V. O dano pessoal no direito do trabalho. 2. ed. São Paulo: LTr, 2010. 278 p.

OLIVEIRA, Sebastião Geraldo de. Proteção jurídica à saúde do trabalhador. 4. ed. São Paulo: LTr, 2002. 526 p.

Proteção jurídica à saúde do trabalhador. 6. ed. São Paulo: LTr, 2011. 608 p.

OLIVEIRA, Simone Santos Silva. Um olhar sobre a saúde a partir da dimensão gestionária do trabalho: contradições e ambigüidades no telemarketing. $184 \mathrm{f}$. Tese (Doutorado em Saúde Pública) - Escola Nacional de Saúde Pública, Fundação Oswaldo Cruz, Rio da Janeiro, 2007.

ORGANIZAÇÃO DAS NAÇÕES UNIDAS. Relatório do Programa das Nações Unidas para o Desenvolvimento: Consumo para o Programa Humano. Lisboa: Trivona, 1998.

ORGANIZAÇÃO INTERNACIONAL DO TRABALHO. Convenção n $^{\circ} 155.20$ jun. 2002. Disponível em: <http://www.ilo.org/ilolex/cgi-lex/convde.pl?P155>. Acesso em: 29 jun. 2011.

ORGANIZAÇÃO MUNDIAL DA SAÚDE. Constituición de La Organización Mundial de La Salud. Disponível em: <http://www.who.int/gb/bd/S/S_documents.htm>. Acesso em: 20 maio 2012.

PADILHA, Norma Sueli. Do meio ambiente do trabalho equilibrado. São Paulo: LTr, 2002. 142 p.

PAIVA, Cynthia Suennia Damasceno Lucena de; BORGES, Lívia de Oliveira. O ambiente de trabalho no setor bancário e o bem-estar. Psicologia em Estudo, Maringá, v. 14, n. 1, p. 5766, jan./mar. 2009.

PEDUZZI, Pedro. Metade das empresas já se adaptou à Lei do Call Center, diz ministro da Justiça. Agência Brasil, Brasília, 19 dez. 2008. Disponível em: <http://www.agenciabrasil. gov.br/noticias/2008/12/19/materia.2008-12-19.4088438939/view>. Acesso em: 3 maio 2011.

PLÁ RODRIGUEZ, Américo. Princípios de Direito do Trabalho. Tradução Wagner D. Giglio. 3. ed. São Paulo: LTr, 2000. 456 p. 
REZENDE, Marcello Santos; BRITO, Jusssara; ATHAYDE, Milton. A automobilização de uma teleatendente para enfrentar as adversidades do trabalho em um Call Center. Revista Laboreal, Porto, v. 5, n. 2, p. 63-75, 2009.

RIBEIRO, Silvia Basílio. Telemarketing enfrenta crise de saúde. Folha de São Paulo, São Paulo, 14 mar. 2004. Caderno Ilustrada, p. E2.

RIOUX, Jean Pierre. Revolução Industrial: 1780-1880. São Paulo: Pioneira, 1975. 262 p.

RIVLIN, Leanne G. Olhando o passado e o futuro: revendo pressupostos sobre inter-relações pessoa-ambiente. Estudos de Psicologia, Natal, v. 8, n. 2, p. 215-220, 2003.

ROCHA, Julio César de Sá da. Direito ambiental do trabalho: mudança de paradigma na tutela jurídica à saúde do trabalhador. São Paulo: LTr, 2002. 221 p.

Direito ambiental e meio ambiente do trabalho. Dano, prevenção e proteção jurídica. São Paulo: LTr, 1997. 340 p.

ROMITA, Arion Sayão. A terceirização e o Direito do Trabalho. Revista LTr, São Paulo, v. 56, n. 03, p. 273-279, mar. 1992.

ROSSETTI-FERREIRA, Maria Clotilde; AMORIM, Katia de Souza; SILVA, Ana Paula Soares da. Rede de significações: alguns conceitos básicos. in: ROSSETTI-FERREIRA, Maria Clotilde et al. (Orgs.) Rede de significações e o estudo do desenvolvimento humano. Porto Alegre: Artmed, 2004. p. 23-34.

ROSSIT, Liliana Allodi. O meio ambiente de trabalho no direito ambiental brasileiro. São Paulo: LTr, 2001. 216 p.

SADY, João José. Direito do meio ambiente de trabalho. São Paulo: LTr, 2000. 205 p.

O direito à sanidade no meio ambiente do trabalho. Revista do Advogado, São Paulo, n. 97, p. 82-88, 2008.

82, p. 63-73, 2005.

Repensando o direito ambiental do trabalho. Revista do Advogado, São Paulo, n.

SANTOS, Antonio Silveira Ribeiro dos. Meio ambiente do trabalho: considerações. Teresina: Jus Navegandi, set. 2000. Disponível em: <jus2.uol.com.br/doutrina/ texto.asp?id=1202>. Acesso em: 29 jun. 2011.

SAÚDE DO TRABALHADOR. A Voz do Brasil. Brasília: Rede Nacional, 24 ago. 2012. Programa de rádio.

SEIDL, Eliane Maria Fleury; ZANNON, Célia Maria Lana da Costa. Qualidade de vida e saúde: aspectos conceituais e metodológicos. Caderno Saúde Pública, Rio de Janeiro, n. 20, v. 2, p. 580-588, 2004. 
SINDICATO DOS TRABALHADORES EM TELECOMUNICAÇÕES NO ESTADO DE SÃO PAULO. Departamento Jurídico. Ações Coletivas. Disponível em: <http://www.sintetel.org/novo/acoes_coletivas.php>. Acesso em: 30 out. 2012.

SILVA, Airton Marinho da. A regulamentação das condições de trabalho no setor de teleatendimento no Brasil: necessidades e desafios. 2004. 129 f. Dissertação (Mestrado em Saúde Pública) - Faculdade de Medicina, Universidade Federal de Minas Gerais, Belo Horizonte, 2004.

; ASSUNÇÃO, Ada Ávila. Negociações sociais para melhoria das condições de trabalho no setor de teleatendimento: o descompasso entre a posição das empresas e a realidade do trabalho. Interface, Botucatu, v. 9, n. 18, p. 553-570, fev. 2005.

SILVA, Cláudia Sampaio Corrêa da; OURIQUE, Luciana Rubensan; OLIVEIRA, Manoela Ziebell de; REIS, Marcia Giovana Pedruzzi; LASSANCE, Maria Célia. Ressignificação da experiência de Orientação Profissional. Revista Brasileira de Orientação Profissional, São Paulo, v. 9, n. 1, jun., p. 75-86, 2008.

SILVA, Edna Lúcia da; MENEZES, Estera Muszkat. Metodologia da pesquisa e elaboração de dissertação. 3. ed. rev. e atual. Florianópolis: Laboratório de Ensino a Distância da UFSC, 2001.

SILVA, Homero Batista Mateus da. Curso de Direito do Trabalho aplicado: direito coletivo do trabalho. v. 7. Rio de Janeiro: Elsevier, 2010. 308 p. 2009. 267 p.

Curso de Direito do Trabalho aplicado: parte geral. v. 1. Rio de Janeiro: Elsevier,

Curso de Direito do Trabalho aplicado: segurança e medicina do trabalho, trabalho da mulher e do menor. v. 3. Rio de Janeiro: Elsevier, 2009. 289 p.

SILVA, José Afonso da. Comentário contextual à constituição. 4. ed. São Paulo: Malheiros Editores, 2007. 1024 p. 2003. $878 \mathrm{p}$.

Curso de direito constitucional positivo. 22. ed. rev. atual. São Paulo: Malheiros,

SILVA, José Antônio Ribeiro de Oliveira. A saúde do trabalhador como um direito humano: conteúdo essencial da dignidade humana. São Paulo: LTr, 2008. 285 p.

As perícias judiciais para a constatação de doença ocupacional: um gravíssimo problema a desafiar uma solução urgente, para a efetiva proteção a saúde do trabalhador. Caderno de doutrina e jurisprudência da Escola de Magistratura da $\mathbf{1 5}^{\mathrm{a}}$ região, Campinas, v. 6, n. 1, fev. 2010. Disponível em: <http://bdjur.stj.jus.br/dspace/handle/ 2011/32491>. Acesso em: 12 set. 2012. p. 11.

SILVA, Otavio Pinto e. Meio ambiente e saúde do trabalhador. Revista do TRT da $2^{\mathbf{a}}$ Região, São Paulo, n. 4, p. 69-119, 2010.

Relações de trabalho e relações de consumo: o futuro da Justiça do Trabalho. Revista do Departamento de Direito do Trabalho e da Seguridade Social, São Paulo, v. 1, n.1, p. 143-162, jan./jun, 2006. 
Subordinação, Autonomia e Parassubordinação nas Relações de Emprego. São Paulo: LTr, 2004. 207 p.

SODRÉ, Marcelo Gomes. A construção do Direito do Consumidor: um estudo sobre as origens das leis principiológicas de defesa do consumidor. São Paulo: Atlas, 2009. 338 p.

SOMMER, Robert. Discipline and field of study: a search for clarification. Journal of Environmental Psychology, New York, v. 20, n. 1, p. 1-4, 2000.

STOKOLS, Daniel. Environmental psychology. Annual Review Psychology, Palo Alto, n. 29, p. 253-295, 1978.

Establishing and maintaining healthy environments. American Psychologist, Washington, v. 47, n. 1, p. 6-22, 1992.

; et al. Evaluating transdisciplinary science. Nicotine \& Tobacco Research, Madison, v. 5, n. 1, p. S21-S39, dec. 2003.

STONE, Bob; WYMAN, John. Telemarketing. São Paulo: Nobel, 1992. 238 p.

SUNDSTROM, Eric. Work environments: offices and factories. In: STOKOLS, Daniel; ALTMAN, Irwin. (Eds.). Handbook of Environmental Psychology. New York: Wiley, 1987. v. 1, p. 733-781.

SÜSSEKIND, Arnaldo; MARANHÃO, Délio; VIANNA, Segadas; TEIXEIRA, Lima. Instituições de Direito do Trabalho. 22. ed. v. 1. São Paulo: LTr, 2005. 651 p.

TRIBUNA DO NORTE. Terceirização de call center das teles é ilegal, diz TST. Natal, Economia, 10 nov. 2012. Disponível em: <http://tribunadonorte.com.br/noticia/terceirizacaode-call-center-das-teles-e-ilegal-diz-tst/236293 > Acesso em: 12 nov. 2012.

UOL NOTÍCIAS TECNOLOGIA. Anatel deve liberar venda de operadoras suspensas nesta quinta, diz Reuters. São Paulo, 2 ago. 2012. Disponível em: $<$ http://tecnologia.uol.com.br/noticias/redacao/2012/08/02/anatel-libera-vendas-de-operadoras -de-telefonia-movel-suspensas.htm>. Acesso em: 2 ago. 2012.

VARGA, László. Após explosão, telemarketing perde fôlego. Folha OnLine, São Paulo, 14 julho 2003. Disponível em: <http://www1.folha.uol.com.br/folha/ dinheiro/ult91u70225.shtml>. Acesso em: 11 set. 2011.

VENCO, Selma Borghi. Centrais de atendimento: a fábrica do século XIX nos serviços do século XXI. Revista Brasileira de Saúde Ocupacional, São Paulo, v. 31, n. 114, p. 7-18, jul./dez. 2006.

Tempos moderníssimos nas engrenagens do telemarketing. 2006. $312 \mathrm{f}$. Tese (Doutorado em Educação) - Faculdade de Educação, Universidade Estadual de Campinas, Campinas, 2006.

VIANNA, Luiz Werneck; BURGOS, Marcelo. Revolução processual do direito e democracia progressiva. In: VIANNA, Luiz Werneck. Democracia e os três poderes no Brasil. Belo Horizonte: Editora UFMG, 2003. 559 p. 
XIMENES, JULIA MAURMANN. Levantamento de dados na pesquisa em direito - a técnica da análise de conteúdo. Instituto Brasiliense de Direito Público. Disponível em: $<$ http://www.idp.edu.br/component/docman/doc_download/145-levantamento-de-dados-napesquisa-em-direito--a-tecnica-da-analise-de-conteudo >. Acesso em: 13 set. 2012. 
APÊNDICE 


\section{UNIVERSIDADE DE SÃO PAULO \\ FACULDADE DE DIREITO \\ PROGRAMA DE PÓS-GRADUAÇÃO EM DIREITO \\ DEPARTAMENTO DE DIREITO DO TRABALHO E SEGURIDADE SOCIAL}

\section{TERMO DE CONSENTIMENTO LIVRE E ESCLARECIDO}

Consinto em participar voluntariamente da pesquisa do doutorando Victor Hugo de Almeida* (Departamento de Direito do Trabalho e Seguridade Social da Faculdade de Direito - Universidade de São Paulo), intitulado “A influência do conflito entre políticas de harmonização da relação de consumo para o Serviço de Atendimento ao Consumidor versus políticas de harmonização da relação de trabalho em telemarketing no meio ambiente do trabalho", sob orientação do Prof. Dr. Otavio Pinto e Silva, concedendo uma entrevista, que será gravada em áudio e posteriormente transcrita, após ser informado(a) dos objetivos desse estudo, ou seja, verificar a influência no meio ambiente do trabalho do conflito entre políticas de harmonização da relação de consumo versus políticas de harmonização da relação de trabalho em telemarketing e seus impactos na saúde e qualidade de vida dos teleoperadores.

Sei que minha participação nesta pesquisa não me trará danos ou despesas; sei que minha identidade será preservada; sei que os resultados poderão, eventualmente, ser publicados ou apresentados em congressos científicos, sem identificação dos participantes; sei que, a qualquer momento, posso desistir de participar dessa pesquisa, sem que essa decisão importe em qualquer conseqüência para mim.

Declaro não ter sofrido qualquer tipo de pressão e ter recebido uma cópia desse Termo, tendo assim a possibilidade de lê-lo quantas vezes se fizer necessário. Tendo tomado conhecimento, concordado com as informações acima e estando ciente de que minha identidade será preservada, autorizo a utilização das informações por mim fornecidas para fins científicos, a publicação do trabalho e a apresentação em congressos científicos.

de de

\section{(assinatura do participante)}

\footnotetext{
*Victor Hugo de Almeida Fone/Fax: (16) 3931.3478 Celular: (16) 9103.2129

E-mail: victormontecchio@usp.br
} 